\title{
NINETEENTH-CENTURY BORNEO
}

\author{
A Study in Diplomatic Rivalry
}


Graham Irwin - 978-90-04-28637-5

Downloaded from Brill.com๑4/26/2023 $02: 45: 21 \mathrm{AM}$

via free access 


\section{VERHANDELINGEI}

VAN HET KONINKLIJK INSTITUUT VOOR TAAL-, LAND. EN VOLKENKUNDE

DE EL XV

\section{NINETEENTH-CENTURY BORNEO}

\section{A STUDY IN DIPLOMATIC RIVALRY}

BY

GRAHAM IRWIN, M.A., Ph.D.

Lecturer in History

University of Malaya

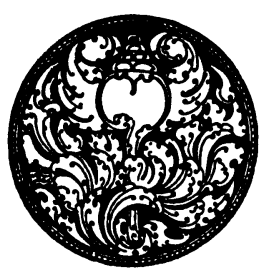

'S-GRAVENHAGE - MARTINUS NIJHOFF - 1955 
In past years, I have sometimes thought what a thing it would be, could the Queen 'in Council' (in Parliament or wherever it were) pick out some gallant-minded, stout, well-gifted Cadet, - younger son of a Duke, of an Earl, or a Queen herself; younger son doomed now to go mainly to the Devil, for absolute want of a career; - and say to him, "Young fellow, if there do lie in you potentialities of gover. ning, of gradually guiding, leading and coercing to a noble goal, how sad is it they should be all lost! They are the grandest gifts a mortal can have; and they are, of all, the most necessary to other mortals in this world. See, I have scores on scores of 'Colonies', all ungoverned, and nine-tenths of them full of jungles, boa-constrictors, rattlesnakes, and Parliamentary Eloquences.... one of these you shall have, you as Vice-King; on rational considerations, and ad vitam aut culpam it shall be yours (and perhaps your posterity's if worthy): go you and buckle with it, in the name of Heaven; and let us see what you will build it to!"

THOMAS CARLYLE

Landgenooten! volgen wij het voorbeeld van Engeland! Het eigenbelang roept ons naar Borneo, maar brengen wij den Borneoten de weldaden, die het christendom ons schenkt, en die met het goud van hunnen grond niet te betalen zijn.... Wij zijn geroepen, om die ongelukkigen uit hunne stoffelijke en zedelijke ellende op te heffen, en daardoor onze eigen nationale grootheid en rijkdom te vermeerderen. Thans is het nog tijd om aan die roeping te voldoen; maar verwaarloozen wij onzen pligt, dan houdt Engeland het dreigend zwaard van Damocles boven onze hoofden, dan 'wordt de scepter van ons genomen en aan een ander gegeven'.

Dr W. R. BARON VAN HOEVELL 


\section{PREFACE}

This study deals with the years 1809 to 1888 , during which the fate of modern Borneo was being decided. In 1809, under the stress of the Napoleonic Wars, and after more than two centuries of intermittent occupation, the Dutch were forced to withdraw from the island entirely. They returned in 1817 , but largely neglected their newly-restored possessions until the arrival on the north-west coast in 1839 of James Brooke, the future 'White Raja' of Sarawak. This event - the most important single occurrence in the history of nineteenth-century Borneo - not only stimulated British interest in the north-western corner of the island, and led directly to the founding of Labuan in 1846, but also obliged the Dutch to look more carefully to the security of their possessions in the south. The succeeding forty years saw a steady increase in the influence and dominion of both powers, until by 1888 the island had been partitioned between the two.

Most writers on nineteenth-century Borneo so far have concentrated on its internal history. Veth, Kielstra, van der Kemp, van Rees, BaringGould and Bampfylde, Keppel, St. John, Rutter, and others have described in great detail and with substantial accuracy the various wars and expeditions, political developments and administrative changes in the areas and during the periods with which they were respectively concerned. I have not attempted to recapitulate their narratives. $\mathrm{My}$ purpose has rather been to interpret existing knowledge in the light of my own researches into the policies and ambitions of the British and Dutch Governments, to view the history of the island not from Bandjermasin or Kuching, but from Batavia, London and The Hague.

The chief sources which $I$ have used are the manuscript records relating to Borneo of the English East India Company, 1812-24 (preserved at the India Office Library, London), of the British Foreign and Colonial Offices, 1842-92 (at the Public Record Office), and of the Netherlands Ministries of the Colonies, 1813-75, and of Foreign Affairs, 1838-70 (at the Rijksarchief in The Hague). Some volumes in these series have been consulted by other writers for particular purposes but, so far as I am aware, no systematic use of them has previously been made. Because no 'student's guide' to the Dutch colonial 
archives has yet been produced, I have given in Appendix ' $\mathrm{A}$ ' a brief description of the records of the Netherlands Ministry of the Colonies which refer to the nineteenth century and which are to be found in the Rijksarchief. This, I hope, may be of value to students working in the same field.

The present work is based on a dissertation entitled 'British and Dutch Policy in Borneo, 1809-1888', which was approved for the degree of $\mathrm{Ph} . \mathrm{D}$. at the University of Cambridge in October 1953. I have since re-written some sections and modified others, using information contained in books and articles which have appeared during the past twelve months.

I am glad to have the opportunity of thanking Prof. D. G. E. Hall and Mr. C. D. Cowan of the School of Oriental and African Studies, London, both of whom read portions of my original manuscript in draft and provided me with many valuable comments and suggestions. During my visits to Holland I was privileged to meet and received generous assistance from a number of Dutch scholars, including Prof. mr. F. M. baron van Asbeck, Prof. dr. J. H. Boeke, Prof. dr. W. Ph. Coolhaas, Prof. dr. J. J. L. Duyvendak, Prof. mr. J. H. A. Logemann, and Prof. dr. T. H. Milo. I am also indebted to the Koninklijk Instituut voor Taal-, Land- en Volkenkunde for generous financial support; to Mr. J. F. Trotter for producing an excellent set of maps from the sketches with which I supplied him; to Mrs. Emily Hahn Boxer for drawing my attention to a collection of Dutch manuscripts which I had missed; to the Secretary of the Borneo Company, Limited, for allowing me to see the early minute books of that organization; and to the staffs of the Public Record Office, the British Museum, and the Rijksarchief, and of the Libraries of the Colonial Office, the Royal Empire Society, the Universities of Cambridge, London, and Leiden, and the Ministerie voor Uniezaken en Overzeese Rijksdelen for numerous acts of kindness and attention.

Finally, I wish to express my great sense of gratitude to Dr. Victor Purcell of the University of Cambridge and Prof. dr. G. Gonggrijp of the Nederlandsche Economische Hoogeschool, Rotterdam, who jointly supervised the research which has resulted in this book.

University of Malaya, May 1954.

GRAHAM IRWIN. 


\section{CONTENTS}

Preface . . . . . . . . . . . . . . . . . $\mathrm{v}$

Contents . . . . . . . . . . . . . . . . . . . . vII

A Note on Spelling . . . . . . . . . . . . . . . . IX

Abbreviations used in Footnotes . . . . . . . . . . . . XI

Introduction . . . . . . . . . . . . . . . . 1

I. Raffles and Borneo . . .. . . . . . . . . . 12

II. The Restoration of Dutch Rule . . . . . . . . . 35

III. The Treaty of 1824 . . . . . . . . . . . . . 52

IV. The White Raja of Sarawak . . . . . . . . . . 71

V. James Brooke and the Dutch Government . . . . . 94

VI. The Founding of Labuan . . . . . . . . . . . 109

VII. The Pirate Controversy . . . . . . . . . . . . 127

VIII. The Dutch Reaction . . . . . . . . . . . . . 151

IX. The Status of Sarawak . . . . . . . . . . . 177

X. The Partition of Borneo . . . . . . . . . . . 191

Conclusion . . . . . . . . . . . . . . . . 215

\section{Appendices}

A. A Note on the Colonial MSS preserved at the Algemeen Rijksarchief . . . . . . . . . . . . 218

B. List of Sources . . . . . . . . . . . . . . . 221

C. Index . . . . . . . . . . . . . . . . . . 243

\section{Maps}

1. Dutch Borneo: Western Division

2. Dutch Borneo: South and Eastern Division

3. Sarawak and Brunei

4. North Borneo 
Graham Irwin - 978-90-04-28637-5 Downloaded from Brill.come4/26/2023 02:45:21AM via free access 


\section{A NOTE ON SPELUING}

Before the publication of the official Rules for Romanizing Malay (Kuala Lumpur, 1904), the spelling of Malay names, at least so far as English writers were concerned, was very much a matter of personal taste. 'Brunei', for example, appears in nineteenth century English works as 'Bruni, Brunai, Bronai, Bronei, Bruneh, Bruné', etc., as well as in the older variants, 'Burni, Bourni, Bournie, Borney, Borne', and 'Borneo' (for 'Borneo Proper'). Dutch authors on the whole showed greater consistency, though 'Berow, Barow, Berau, Berauw, Baroe, Barong', and 'Brow' may all be seen in place of modern 'Berouw', while 'Sambaliung, Sambaliong', etc. often occur where 'Sambalioeng' would normally be used today.

In order to avoid confusion in these and similar cases, I have adopted the standard modern English and Dutch romanizations for the names of places in British and Dutch Borneo respectively, altering where necessary the spelling of words in quotations from original sources. Malay and Arabic personal names have been given in their modern English romanizations irrespective of source.

The Chinese names in Chapter VIII have been transposed from the original characters in accordance with the (modified) Wade-Giles system. This has sometimes resulted in romanizations which are markedly different from the contemporary Dutch versions, many of which were taken from local Chinese dialects. In such cases I have reproduced these contemporary romanizations in appropriate footnotes. 
Graham Irwin - 978-90-04-28637-5 Downloaded from Brill.come4/26/2023 02:45:21AM via free access 


\section{ABBREVIATIONS USED IN FOOTNOTES}

$B T L V$

Buit.Zaken

C.O.

Fac. Rec.

F.O.

Bijdragen tot de Taal-, Land-en Volkenkunde van Nederlandsch-Indië (uitgegeven door het Koninklijk Instituut voor de Taal-, Land- en Volkenkunde van Nederlandsch-Indië; known after 1950 as the Bijdragen tot de Taal-, Land-en Volkenkunde).

Manuscript records of the Dutch Ministry of Foreign Affairs, preserved at the Rijksarchief, The Hague.

Manuscript records of the British Colonial Office, preserved at the Public Record Office, London.

Factory records of the English East India Company, preserved at the India Office Library, London.

Manuscript records of the British Foreign Office, preserved at the Public Record Office, London.

Journ. Ind. Arch. Journal of the Indian Archipelago and Eastern Seas (sometimes known as 'Logan's Journal').

$J R A S M B$

Journal of the Malayan Branch of the Royal Asiatic Society.

$J R A S S B$

Journal of the Straits Branch of the Royal Asiatic Society.

Kol.

Manuscript records of the Dutch Ministry of the Colonies, preserved at the Rijksarchief, The Hague.

$N T v N I$

Natuurkundig Tijdschrift voor Nederlandsch-Indië.

P.P.

British Parliamentary Papers.

Stb.

Staatsblad van Nederlandsch-Indië.

$T T L V$

Tijdschrift voor Indische Taal-, Land- en Volkenkunde (uitgegeven door het Bataviaasch Genootschap van Kunsten en Wetenschappen).

$T v N I$

Tïdschrift voor Neêrland's (Nederlandsch-) Indië. 
Graham Irwin - 978-90-04-28637-5 Downloaded from Brill.come4/26/2023 02:45:21AM via free access 


\section{INTRODUCTION}

"The island of Borneo extends from $7 \circ 7^{\prime}$ north to $4^{\circ} 12^{\prime}$ south latitude, and from $108^{\circ} 45^{\prime}$ to $119^{\circ} 25^{\prime}$ east longitude; measuring at its extreme length nine hundred miles, at its greatest breadth seven hundred, and in circumference three thousand... Situated in the track of the most extensive and valuable commerce, intersected on all sides with deep and navigable rivers, indented with safe and capacious harbours, possessing one of the richest soils on the globe, abounding in all the necessaries of human life, and boasting commercial products that have in all ages excited the avarice and stimulated the desires of mankind, - with the exception of New Holland, it is the largest island known".

This eulogistic description of Borneo was written in 1812 by the English merchant and traveller, John Hunt. ${ }^{1}$ Its author believed that, given an enlightened administration, the island could quickly become a profitable field for European commercial speculation, and most contemporary observers, Dutch as well as British, would have agreed with him. Yet, as the experience of the next eighty years was to show, such confident predictions were totally unjustified. Hunt's optimism was the result partly of mistaken ideas about the economic geography of Borneo, and partly of a failure to appreciate the problems involved in trying to convert a hostile and largely savage population from piracy and head-hunting to a more civilized - and a more commercial way of life.

The "safe and capacious harbours" which he mentions, for example, exist only in the far north of the island. The West, South, and East Coasts are singularly free from suitable anchorages for European ships, and consist for the most part of mud banks and mosquito-infested mangrove and nipah swamps. Some of the larger rivers are navigable for hundreds of miles, but with one or two exceptions their mouths are blocked by sand bars, which permit entrance only at high tide, and

1 'Sketch of Borneo, or Pulo Kalamantan', in Malayan Miscellanies, Vol. i, No. 8. 
then only for vessels of shallow draught. Hunt was also mistaken in thinking that the soil of the island was exceptionally fertile. Unlike Java and Sumatra, Borneo shows no sign of recent volcanic activity. By comparison with theirs its soil is mature, having been leached out by centuries of tropical rain, and quickly spoils when the protective forest cover is removed.

The melancholy story of past attempts to develop the resources of the island, moreover, did not suggest that its inhabitants would ever willingly acquiesce in European rule. Since early in the sixteenth century the Portuguese, Spaniards, Dutch, and British had all tried in various ways and at different times to establish relations with the coastal princes, but all their efforts had ended in failure. In the annals of European nations before 1800 Borneo figures chiefly as a land of treachery, violence, and sudden death.

Modern ethnologists divide the native inhabitants of the country into more than forty separate peoples. Of these the best-known, though not the most numerous, are the Dyaks. It is usual nowadays to reserve this name for the so-called 'Land-Dyaks', and for the 'Sea-Dyaks' or 'Iban' of Sarawak, but during the nineteenth century it was often applied to other tribal groups as well. All the aboriginals of Borneo, whether Dyaks or not, have remained at a very primitive cultural level. Some are nomadic forest-dwellers, living by fishing and by hunting with blow-pipe and poisoned dart; others have learnt rudimentary methods of agriculture. A hundred years ago head-hunting was practically universal among them, and in special circumstances is still liable to recur. A brisk traffic in Japanese heads sprang up between some of the East Coast tribes and the Allied invasion forces in 1945.

Throughout its history Borneo has received numerous cultural infusions from the outside world. Archaeological evidence shows that it was well within the sphere of the Hindu colonization movement and that direct intercourse existed with India from very early times. Brahmin sacrificial posts dating from the fourth century A.D. have been found at Koetei on the East Coast, and recent discoveries near Sambas point to early Hindu influences on the West Coast also. During the heyday of the Buddhist kingdom of Sri Vijaya in Sumatra (c. 800), western Borneo was a favoured stopping-place on the long voyage from India to China. At this time probably most of the West Coast was held in subjection by Sri Vijaya. After the rise of the Hindu-Javanese empire of Majapahit (c. 1300) the island came under Javanese influence, and a regular tribute was exacted by the Majapahit kings from all parts of 
the coast. The people of Brunei, for example, a district in the northwest, contributed "a jar of the young pinang fruit" every year."

Contacts with China also began at a very early date, possibly as long ago as the third century B.C. Between 600 and 1500 A.D. there are numerous references in the Chinese dynastic histories to visits which were paid to the Emperor of China's court by ambassadors from 'Po-lo, P'o-li, Po-ni, Ye-po-ti', etc. - names which are generally accepted as standing for places on the West Coast of Borneo. In the northern part of the island it is traditionally believed that a Chinese settlement once existed near the Kinabatangan River, and some of the North Borneo tribes certainly give every indication of being part-Chinese in origin. ${ }^{3}$

During the three or four hundred years before the beginning of the European period, Borneo received frequent influxes of colonists from the Malay Peninsula and from the islands of the Archipelago. The settlements formed by these immigrants - Malays from the west, Javanese from the south, Bugis and Sulus from the east and north-east - provided nuclei for the rival states which soon sprang up all around the island. In some areas the new-comers succeeded in enslaving the original inhabitants, but they remained essentially seafaring and mercantile peoples, and their influence was confined to the river valleys and coastal plains.

After the fall of Majapahit the religion of Islam, which had already spread from Sumatra to the Malay Peninsula and Java, was carried across the sea to Borneo. The Muslim Sultanate of Brunei dates from the end of the fifteenth century, when traders brought the new faith from Malacca. During the following century Muslim dynasties were founded at Sambas, Soekadana, and Landak on the West Coast and at Bandjermasin on the South. The last-named was tributary to the Sultanate of Demak in north-eastern Java, while Sambas had ties with Johore and Soekadana with Soerabaja. All these coastal principalities lived by preying on one another and on passing ships, and by extorting

2 Sir Hugh Low, 'Sĕlěsilah (Book of the Descent) of the Rajas of Bruni', $J R A S S B$, June 1880 , p. 2. Sir Richard Winstedt, 'A History of Malaya', $J R A S M B$, March 1935, p. 19. K. A. Nilakanta Sastri, 'A note on the Sambas finds', JRASMB, September 1949, p. 16. J. Eisenberger, Kroniek der Zuider - en Oosterafdeeling van Borneo, p. 3.

3 Victor Purcell, The Chinese in Southeast Asia, pp. 15 and 25-8. Sir Roland Braddell, 'A note on Sambas and Borneo', JRASMB, September 1949, pp. 3-5 and 11. W. P. Groeneveldt, 'Notes on the Malay Archipelago and Malacca', Miscellaneous Papers relating to Indo-China and the Indian Archipelago, pp. 223-34. H. R. Hughes-Hallett, 'A sketch of the History of Brunei', JRASMB, August 1940, pp. 24-5. 
taxes and tolls from the aboriginal peoples whom they subjected to their rule. ${ }^{4}$

The earliest first-hand account of Borneo by a European is a description of the Sultanate of Brunei written by Anthony Pigafetta, one of the companions of Magellan. Pigafetta visited Brunei in 1521, shortly after his captain's death in the Philippines. He was very favourably impressed by the opulence of the Sultan's court, and estimated that the town contained "twenty-five thousand fires or families". ${ }^{5}$ This figure seems unduly high, but other sources confirm that Brunei was a powerful state at the beginning of the sixteenth century. From 1530 onwards it maintained a close commercial intercourse with the Portuguese at Malacca, and in 1577 and 1580 the Spanish Government of the Philippines sent naval expeditions against it with the object of placing on the throne a Sultan favourable to their rule. In 1645 the wide-spread depredations of Brunei pirates led to a third Spanish attack. Neither the Spaniards nor the Portuguese, however, succeeded in establishing permanent dominion over Brunei or any other part of Borneo. ${ }^{6}$

When the first Dutch merchant fleets began arriving in the East at the end of the sixteenth century, most of the island was still quite unknown to Europeans. With characteristic energy the Dutch soon opened commercial negotations with the Sultanate of Bandjermasin on the South Coast, for they hoped to develop a trade in pepper between Bandjermasin and Bantam in Java. In 1603 a factor was installed at the Sultan's capital, but four years later the Banjars lured the crew of a Dutch ship on shore and murdered them to a man. To avenge this outrage Netherlands forces attacked Bandjermasin in 1612, and destroyed it so completely that the Sultan had to move his court inland to Martapoera. Trade relations were not resumed until 1635 . In that year the Sultan signed a pepper contract providing for the delivery of

4 Low, op. cit., pp. 1-2 and 6-7. E. Netscher, 'Kronijk van Sambas en van Soekadana. $\therefore$ TTLV, 1853, pp. 4-5. J. R. Logan, 'Traces of the origin of the Malay kingdom of Borneo Proper...', Journ. Ind. Arch., 1848, pp. 513-23. H. T. Colenbrander, Koloniale geschiedenis, Deel ii, pp. 280-1.

5 Anthony Pigafetta, 'Account of Magellan's Voyage', in The First Voyage Round the World (ed. Lord Stanley of Alderney), p. 114.

B J. R. Logan, 'Notices of European intercourse with Borneo Proper prior to the establishment of Singapore in 1819', Journ. Ind. Arch., 1848, pp. 499 and 503. P. J. Veth, Borneo's Westerafdeeling, Deel i, pp. xxxiii-xxxvii.

The Portuguese established a factory at Martapoera in 1690, but withdrew it four years later after an attack on three Portuguese ships. 
pepper to the Dutch East India Company at a fixed price, but this arrangement, too, was short-lived. In 1638 another Dutch ship was surprised, sixty-four Dutchmen were killed, and all their treasure and goods stolen. Forty more Hollanders lost their lives in an affray at Kota Waringin shortly afterwards. In 1664 a new contract was drawn up, giving the Company a monopoly of Bandjermasin pepper once again but, after vainly trying for five years to obtain the stipulated deliveries, the Dutch withdrew from the South Coast in 1669 and did not return until the following century. ${ }^{7}$

Similar catastrophes befel their early establishments in the western part of the island. In 1610 a Dutch factory at Sambas was attacked, and all the Company's representatives put to death. Twelve years later, during a war between Soekadana and the Javanese state of Mataram, the Company's settlement there too was razed to the ground, though on this occasion no Dutch lives were lost. Later in the century the Netherlands Indian Government intervened in the politics of the West Coast with more success. When in 1698 the Raja of Landak, then at war with Soekadana, appealed for help to the Sultan of Bantam, the Dutch decided to support his cause, and the following year a combined Netherlands-Bantam-Landak force assaulted Soekadana. demolished it completely, and chased its ruler into the interior. From then on all the West Coast states recognized the suzerainty of the Sultan of Bantam and, since this prince was already a vassal of the Netherlands, the Company now possessed at least a theoretical supremacy over western Borneo. ${ }^{8}$

Nevertheless, occasional punitive expeditions of this kind were no substitute for effective occupation, and if any lesson could be drawn from Dutch experiences in Borneo during the seventeenth century, it was that nothing less than the presence of permanent military garrisons would ensure the fulfilment of contracts signed by the local princes. Accordingly, when the Company negotiated a new pepper contract with Bandjermasin in 1747, it also obtained permission from the Sultan to erect a Government fort at Tabanio. In 1785 a dynastic quarrel within the Sultanate provided the opportunity for a further extension of

7 François Valentyn, 'Beschryvinge van het Eiland Borneo, en onzen Handel aldaar', in Oud en Nicuzv Oost-Indien, Deel iii, Stuk 2, pp. 244-6. L. C. D. van Dijk, Neêrland's vroegste betrekkingen met Borneo, den Solo-archipel, Cambodja, Siam, en Cochin-China, pp. 1-18. E. B. Kielstra, De vestiging van het Nederlandsch gezag in den Indischen archipel, pp. 184-5. Colenbrander, op. cit., Deel ii, p. 280.

8 Veth, op. cit., Deel i, pp. 201-9, 233-7. Colenbrander, op. cit., Deel ii, pp. 281-2. 
Dutch power. The Company's forces intervened on the side of one of the contestants and, after winning his battles for him, placed him on the throne on condition that he ceded his newly-acquired dominions to the Netherlands Indian Government. In 1787 the Dutch East India Company became the "sovereign lord, owner, and possessor of the whole kingdom of Bandjermasin". 9

The tactics of playing off one native faction against another enabled the Dutch to increase their authority on the West Coast as well. In 1772 an Arab pirate and adventurer named Abdu'r-Rahman had established himself at the village of Pontianak near the mouth of the Landak River. When the Raja of Landak complained to the Sultan of Bantam about this flagrant violation of his territory, the Dutch saw a chance to take matters into their own hands. Having persuaded the Sultan of Bantam to surrender to them the dormant sovereign rights which he possessed in Borneo, they granted Abdu'r-Rahman full recognition as Sultan of Pontianak, placed a factory at his capital, and encouraged him to suppress any state in the area which refused to accept their supremacy. This policy led in 1786 to a joint expedition by Dutch and Pontianak forces against Soekadana, and the following year the Bugis settlement of Mampawa was also attacked. ${ }^{10}$

By 1787, therefore, by means of a mixture of force and diplomacy, the Dutch had successfully established their influence in both western and southern Borneo. In the East Indies as a whole, however, their power was already beginning to decline. Outwardly, the Dutch East India Company seemed as strong as ever, but its internal administration had become thoroughly inefficient and corrupt. Defective accountancy and wild borrowings over a long period of years had reduced its finances to anarchy. When Holland entered the War of American Independence in 1780, moreover, the British Navy blockaded Dutch home ports; this meant that the produce of Java could not be marketed, and the Company was soon on the verge of bankruptcy. Finally, when the Treaty of Paris of 1784 opened the Archipelago to the ships of all nations, the system of strict commercial monopoly upon which Dutch prosperity in the Far East traditionally depended could no longer be maintained.

In these circumstances the Company's newly-won supremacy in

- Article VI of the Contract of August 13th, 1787. (Quoted in C. Nagtegaal, De voormalige zelfbesturende en gouvernementslandschappen in Zuid-Oost Borneo, p. 7). Kielstra, op. cit., pp. 186-7.

10 Veth, op. cit., Deel i, pp. 254-60, 273-5. 
Borneo became an embarrassment almost as soon as it had been achieved. In 1790 the authorities at Batavia declared that the settlements on the West Coast were "useless and intolerable nuisances", 11 and a year later gave orders for them to be withdrawn. In 1797 the provinces ceded by the Sultan of Bandjermasin ten years previously were handed back to him and, by the close of the century, the only visible evidence that the Dutch East India Company had ever exerciser authority in the island at all was one small Government fort at Tatas on the South Coast.

Throughout the whole period during which the Dutch were attempting to develop a trade with Borneo they had to meet continuous and severe competition from the merchants of other nations, particularly from the Chinese. Every year large numbers of Chinese junks visited all parts of the coast and carried away not only pepper, gold, and diamonds - the chief attractions for European traders - but also camphor, rattans, wax, resin, timber, and table delicacies like agar-agar (sea-weed), tripang (bêche-de-mer), sharks'-fins, and edible birds'nests. ${ }^{12}$ The arrival at Bandjermasin of a dozen or more Chinese junks annually was the principal reason why the Dutch were never able to hold the Sultan of Bandjermasin to his pepper contracts; whenever possible he sold to Chinese merchants rather than to Dutch because the former offered him a better price.

Another competitor in the Borneo trade from the early seventeenth century onwards was the English East India Company. The 'Petition of the Merchant Adventurers' presented to Queen Elizabeth in 1599 had declared that Borneo was one of the places "abounding in great wealth and riches" where neither the Portuguese nor the Spaniards possessed "any castle, fort, blockhouse, or commandment". ${ }^{13}$ During the next hundred and fifty years repeated attempts were made by the English Company to gain a foothold in the island, but all were unsuccessful. ${ }^{14}$ Dutch jealousy was largely responsible, though an important contributory cause of the Company's failure was the in-

11 Quoted by Veth, op. cit., Deel i, p. 282.

12 Valentyn, op. cit., Deel iii, Stuk 2, p. 237. John Leyden, 'Sketch of Borneo', in J. H. Moor, Notices of the Indian Archipelago and adjacent countries... (Appendix). Charles Assey, On the Trade to China and the Indian Archipelago ..., pp. 7-8.

13 Quoted in Johannes Willi of Gais, The Early Relations of England with Borneo to 1805 , p. 1. 
competence of its local representatives. The memoirs of a merchant captain of the day, Alexander Hamilton, contain a description of the chief factor at Bandjermasin which may be taken as typical of the Company's servants in Borneo during the seventeenth and early eighteenth centuries. This official - "a Mr. Cunningham", Hamilton calls him - "was bred a surgeon, and had turned virtuoso; would spend whole days in contemplating on the nature, shape, and qualities of a butterfly or a shellfish, and left the management of the Company's business to others as little capable as himself, so every one but he was master". 15

These early English settlements on the Borneo coasts were founded primarily to provide points d'appui from which Great Britain could compete with the Netherlands in the spice trade of the Moluccas. Factories were maintained by the English East India Company for a similar purpose at Bantam (until the Dutch conquered this part of Java in 1682) and at other places in the Archipelago. But during the course of the eighteenth century the English Company's interest in spices declined, and almost all its attention outside the Indian subcontinent became concentrated on China and the China tea trade. In British eyes Borneo was now of less importance as an outpost on the way to the Moluccas, but of increasing importance as the possible site for a much-needed commercial entrepôt between the Straits of Malacca and China.

In order to buy tea the Company's agents in China needed exchange commodities, since Great Britain's staple export at this time, woollen goods, was difficult to sell there. The Hong merchants at Canton would always accept bullion, but the drain of precious metals to the East disturbed contemporary political economists, and the export of bullion from England was frowned upon. After the Seven Years' War, moreover, the silver which the Company had been accustomed to earn by trading with the Spanish Philippines could no longer be obtained in quantity. A source of suitable exchange goods for the China trade was ultimately provided by India; opium and raw cotton carried to Wham-

14 Factories were maintained by the English East India Company at Soekadana, 1612-22 and 1693-4, at Sambas and Landak, c. 1614, and at Bandjermasin, 1615-55 (intermittently), 1700-7, and 1737-47. (T. C. P. Edgell, 'English trade and policy in Borneo and the adjacent islands, 1667-1786': M. A. Thesis, University of London, 1935, passim. Sir William Foster, England's Quest of Eastern Trade, pp. 248-51).

15 Captain Alexander Hamilton, 'A New Account of the East Indies', in John Pinkerton, Voyages and Travels, Vol. viii, pp. 458-9. 
poa and Canton by the 'country ships' of Madras, Bombay and Calcutta found a ready sale, and financed the Company's tea purchases with complete efficiency. But this was a development of the late eighteenth and early nineteenth centuries, and large amounts of silver were still being exported direct from England to China as late as 1780. In the meantime, while the 'country trade' of India was still in its infancy, the Company had attempted to solve the problem of its unfavourable China trade balance by alternative means. ${ }^{16}$

Between the north-east coast of Borneo and Mindanao stretches the long chain of islands known as the Sulu Archipelago. In 1759 Alexander Dalrymple, a servant of the Company at Madras and an experienced traveller in the Eastern Seas, suggested that Sulu would provide an ideal site for a British trading mart or emporium. A settlement in this area, he pointed out, would possess two great advantages: it would not only serve as a convenient 'counter' for the distribution of British and Indian goods to the Malayan islands, but also, by attracting to itself the southward-bound Chinese junk trade, would bring British woollens before the merchants of northern China, of whom few had ever been in touch with British manufactures of any kind because of the strict monopoly enforced by the Hongs at Canton. In Dalrymple's view, a British trading post in Sulu or in nearby Borneo would "extend the scene of traffic into the unfrequented extremities of Asia". ${ }^{17}$

In June 1760 his plan was approved by the Governor and Council at Madras, and he immediately set sail for the Sulu Archipelago to put it into execution. Early the following year he persuaded the Sultan of Sulu to enter into provisional 'Articles of Friendship and Commerce' with Great Britain, and obtained permission to establish a factory within the Sultan's dominions. After making a thorough examination of the area he decided that the island of Balambangan, off the northern tip of Borneo, would be suitable for the purpose, and here, on January 23rd, 1763, he hoisted the British flag. Returning to Sulu in September, he thwarted a Dutch attempt to induce the Sultan to sign an exclusive commercial alliance with the Netherlands, and persuaded him instead

18 C. Northcote Parkinson, Trade in the Eastern Seas (1793-1813), pp. 336-56. Michael Greenberg, British Trade and the Opening of China 1800-42, pp. 5-17. Vincent T. Harlow, The Founding of the Second British Empire 1763-1793, Vol i, pp. 63-7.

17 Alexander Dalrymple, $A$ Plan for Extending the Commerce of this Kingdom and of the East-India-Company, p. 89. Cf. Harlow, op. cit., p. 72. 
to cede to the English East India Company the whole of north-eastern Borneo and part of the island of Palawan. This grant was formally confirmed by a treaty between Sulu and the Company on June 8th, $1764 . .^{18}$

Another nine years went by, however, before Dalrymple's diplomatic successes in Sulu were put to any effective use. British anxiety lest his schemes should lead to friction with Spain, which possessed longestablished, if shadowy, territorial claims in the Sulu Archipelago, and the Company's own preoccupation with the affairs of India, where the Mogul Empire was in process of final disintegration, were the principal causes of the delay. A small British factory was eventually established at Balambangan in 1773, but it was corruptly and inefficiently managed, fulfilled none of the purposes for which it was designed, and had to be hurriedly abandoned in February 1775 following an attack by a party of hostile Sulus. ${ }^{19}$ Another attempt, in 1803, to plant a factory at Balambangan also failed miserably. After the garrison had nearly starved, the island was evacuated in 1805. The East India Company did not possess a 'station to the eastward' of its own until Sir Stamford Raffles founded Singapore fourteen years later.

When the nineteenth century began, therefore, the British and Dutch Governments had come to regard Borneo from different points of view. For both nations the island had long provided a limited outlet for trade, and was expected to become more valuable in this respect in the future. But whereas the Dutch always thought of Borneo in relation to Java, and hoped, when circumstances allowed, to make it part of the Netherlands Indies, the British had no immediate territorial ambitions in the island. To them its significance was primarily strategic, for it lay on the flank of their vital sea routes to China. Throughout the century one of the mainsprings of British policy in Borneo was a belief that the northern portion of the island, where these trade routes met, must

18 Cf. Alexander Dalrymple, $A$ Full and Clear Proof that the Spaniards can have no Claim to Balambangan (London, 1774).

By the Treaty of June 8th, 1764, the Company obtained possession of the whole of northern Borneo from Kimanis on the West Coast to 'Towson Abai' (Terrusan Abai?) on the East, together with Labuan, Banggi, Palawan, and all other islands lying to the north of Borneo. This huge area was not much smaller than the concession secured by Baron von Overbeck and Alfred Dent in 1877-8, which subsequently became the territory of the British North Borneo Company.

10 Willi of Gais, op. cit., Chaps. III and IV. Harlow, op. cit., pp. 81-95. 
in no circumstances be permitted to fall into the hands of a foreign power.

During the season of the south-west monsoon (April to October) the normal route to China from England or India was via Sunda or Malacca Straits and the South China Sea - that is, to the west of Borneo. This channel was known as the 'Western Passage'. When the north-east monsoon was blowing it became impracticable, and ships clearing Sunda or Malacca Straits for China had to take either the 'Eastern Passage', which ran south of Borneo and then north via Macassar Strait and the Sulu Sea (and thus to the east of Borneo), or the 'Pitt Passage' - south of Celebes and north between Halmahera and western New Guinea. ${ }^{20}$ Even in later years, when steam had replaced sail and the vagaries of the monsoon could be disregarded, northern Borneo retained its strategic significance in British eyes, since it flanked not only the shipping highway between Singapore and Hong Kong, but also the new and increasingly important trade route between China and eastern Australia, which passed through Palawan Passage and the Sulu Sea.

Thus during the nineteenth century British interest in Borneo tended to become concentrated for strategic reasons on the northern part of the island, while the Dutch, for political and commercial reasons, sought to extend their influence in the southern. Sooner or later the policies of these two powers were bound to conflict. As the century progressed, developing competition between them - sometimes open, more often veiled - posed one vital question: how much territory in Borneo could be absorbed by the Dutch, who were the first in the field but the weaker nation, before the British, more powerful than their rivals but comparative late-comers, decided to stake out a claim?

20 Alexander Dalrymple, 'Memoir concerning the Passages to and from China', pp. 1-5: in General Collection of Nautical Publications. 


\section{CHAPTER I}

\section{RAFFLES AND BORNEO}

In August 1809 Lieutenant-Colonel S. J. van Thiel, a special commissioner appointed by the Governor-General of the Netherlands Indies, set sail from Batavia for Fort Tatas, a small Dutch outpost near Bandjermasin on the South Coast of Borneo. He carried with him instructions to hand over the fort and nearby barracks to the Sultan of Bandjermasin, and to transport the civil and military establishment of the South Coast Residency back to Java. After a spasmodic and precarious existence lasting nearly two centuries, the oldest, and the sole remaining, Dutch settlement in Borneo was being broken up.

The orders van Thiel had received from the Governor-General, Marshal Daendels, were prompted by harsh military necessity. Napoleon, the European master of the Netherlands, had sent Daendels to Java to organize its defences, and to assist, when opportunity offered, in the conquest of India. The passage of time, however, had converted Java into a beleaguered fortress rather than a potential springboard for invasion. The Dutch colonial navy had been swept from the Archipelago in two engagements in 1806 and 1807, fought off the coast of Java, and the Moluccas had been captured by a British admiral in 1808. With the prospect of a long British blockade ahead of him, Daendels was compelled to husband his resources in order to meet the attack he knew must come. By 1809 he was busy building strategic roads throughout the length of Java, training an army, and collecting munitions and warlike stores. He had no ships to keep open communications with the Outer Islands, and no men to garrison the outposts and factories there.

The settlement at Bandjermasin might have been retained a little longer had it been sufficiently prosperous to contribute to the government revenues. As it was, so far from adding to the resources of Java, it could not even pay its own way. In 1809 government purchases of pepper, the staple export of southern Borneo, were causing "an annual loss to the state of 4.4 rix-dollars per pikul - reckoning on the delivery of 3,000 pikuls a year - which represents 14,750 rix-dollars in silver 
money". ${ }^{21}$ Serious at any time, losses like these could not be afforded in time of war, when the finances of Java were already stretched to the limit. The Residency of the South Coast of Borneo had become too expensive a responsibility, and must be discontinued.

When he learnt that the Dutch intended to evacuate his territories, the Sultan of Bandjermasin was greatly dismayed. Their departure would mean that the position of prominence which he had enjoyed among his neighbours in recent years, and which he owed largely to Dutch protection, was in danger of being lost. Alone, he could not hope to defend his kingdom for long, and he therefore turned for protection elsewhere, sending embassies through the Archipelago in search of assistance. One of these, dispatched soon after the Dutch evacuation, arrived at the British settlement of Penang, but on that occasion no response was forthcoming. A second, however, was sent to the British authorities at Malacca early in 1811, and events were to show that the Sultan of Bandjermasin could hardly have been more fortunate in his selection of time and place. His envoys were received by the Englishman most likely, at that time, both by position and inclination, to listen favourably to his proposals - the newly-appointed 'Agent to the Governor-General with the Malay States', Thomas Stamford Raffles.

The Bandjermasin embassy did not arrive at Malacca entirely unheralded. A Mr. Alexander Hare, one of the leading members of the British merchant community there, had been keeping an eye on events in Borneo for some time. He considered that the island offered golden opportunities for trade, even though two vessels he had sent to Bandjermasin in 1810 had returned "empty-handed and with nothing but meaningless promises". ${ }^{22}$ Now, however, he saw his chance, and it was Hare who introduced the Sultan's two envoys to Raffles. They requested protection for Bandjermasin, and proposed that a British resident, preferably Hare himself, should be appointed to act as adviser to the Sultan. ${ }^{23}$

Raffles' presence in Malacca was the result of the long-expected decision to invade Java, taken by the British Government immediately

21 Besluit of May 19th, 1809. (J. A. van der Chijs, Nederlandsch-Indisch plakaatboek, Deel $\mathrm{xv}$, p. 727). One rix-dollar (rijksdaalder) equalled 48 stuivers at this time, or about $\$(\mathrm{Sp}$.) 1.6.

22 Report of Commissioner van Boekholtz, 'Nederlandsch-Indië in 1817', TvNI, 1861 , i, p. 358.

${ }^{23}$ Cf. C. A. Gibson-Hill, 'John Clunies Ross and Alexander Hare, Merchant', $J R A S M B$ (1952, Pts. 4 and 5), p. 22. 
after Napoleon's annexation of Holland in 1810. His main duty was to find out all he could about the best route to Java for naval convoys, about enemy strengths and dispositions, and about defensive preparations on the island. He also took upon himself the wider task of establishing contact with native rulers throughout the Archipelago in order to secure their co-operation when the British eventually assumed control of all Dutch possessions in the Indies. He therefore lost no time in opening friendly negotiations with the Sultans of Mataram and Madura, and with the Rajas of Bali and Lombok, and was soon able to turn his thoughts to Borneo. Already his own researches into the natural resources of the Archipelago had convinced him that this island, in particular, had suffered gravely from lack of attention in the past. $\mathrm{He}$ had received reports of the "very good pepper and rattans" obtainable at Bandjermasin and also of the "considerable quantities of fine wax, birds' nests, deers' horns and tendons, skins and wood" to be found there. "The island of Borneo", he wrote enthusiastically to the Governor-General of Bengal, the Earl of Minto, "is not only one of the most fertile countries in the world, but the most productive in gold and diamonds". ${ }^{24}$

It was not surprising, therefore, that the Sultan of Bandjermasin's envoys found Raffles ready to meet them more than half way. Their proposals fitted in perfectly with his instructions. Indeed, they did more; they agreed closely with the high plans he was already forming for the advancement of 'the British interest' not merely in Java but throughout the Eastern Seas. He wrote to Lord Minto early in 1811: "I trust your Lordship will approve of the measures I have taken (and will take) to encourage and support by hopes and expectation the declining authority and consequence of the Legal Sovereign of a Country so nearly connected with the scene of our more extended political operations". 25

When Lord Minto himself arrived at Malacca at the head of the Java expedition, further envoys from the Sultan of Bandjermasin were presented to him. To their reiterated request for protection and the sending of a British resident the Governor-General gave his emphatic approval. With the invasion of Java about to begin, the establishment of a British settlement in southern Borneo could not be long delayed.

24 Raffles to Minto, June 10th, 1811. (Sophia Raffles, Memoir of the Life and Public Services of Sir Thomas Stamford Raffles... ., p. 59).

25 Raffles to Minto, January 31st, 1811. (India Office Library MSS Eur. E. 104, 'Raffles Collection II' pp. 121-8). 
In deciding to occupy Java, the British Government were influenced primarily by strategic considerations. In their view it was imperative that the Dutch possessions in the Far East, now under French control, should not be allowed to become naval bases from which attacks could be launched against British shipping employed in the trade to China. The Directors of the East India Company had agreed that Java would have to be occupied, but the undertaking was never regarded by them as more than a temporary expedient, a necessity brought about by the circumstances of war. Both Minto and Raffles, on the other hand, certainly based their hopes on the permanent retention of Java and its dependencies. When Raffles was appointed Lieutenant-Governor of Java he set about reorganizing its administration with the possibility of an indefinite British occupation always in mind, though he well understood, and regretted profoundly, that the fruits of his labours might be reaped by the Dutch.

The fate of the Outer Islands (as the dependencies of Java were then called) was less certain. Marshal Daendels had been compelled to withdraw his forces from all islands east and north of Java before the British invasion began; and when, after a short campaign, Daendels' successor, General Janssens, made his submission to the British commander, General Auchmuty, on September 18th, 1811, he was not allowed to make any reservations with respect to those parts of the Archipelago which were already in British hands. "General Janssens", ran the first article of the capitulation, "will surrender to General Auchmuty the island of Java and its dependencies"; to which the British replied: "The events of the war having placed all the provinces of Java west of Samarang in the power of the British forces, General Janssens can make stipulations only for those which lie east of Samarang, and which are not already in the possession of the armies of His Britannic Majesty". ${ }^{26}$ If the principle of 'present occupation' could be applied so strictly to Java in 1811, how much more appropriately could it be applied to the Moluccas, which had been under British control since 1808? And to Borneo, which the Dutch had entirely abandoned in 1809 ? So Raffles argued, and it was with the future of 'the British interest' in the Archipelago in mind that he turned his attention to those parts of the 'former' Dutch colonies which might be considered independently from the surrender of Java, and which

${ }^{26}$ Quoted in Octave-J.-A. Collet, L'île de Ja'́a sous la domination francaxise, p. 540 . 
he was confident could be withheld from the Dutch even though Java itself might be given back. On April 7th, 1812, in pursuance of this policy, and with the approval of the Governor-General of Bengal, Raffles instructed Alexander Hare (who had moved by this time to Java) to found a British settlement at Bandjermasin in Borneo by treaty with the Sultan of that place.

The first appearance of the new 'raj' at Bandjermasin was scarcely likely to make a favourable impression on the Sultan and his court. Hare took with him an Assistant-Resident (Mr. van de Wahl), a Chief of Armed Police, two surgeons, a bookkeeper, a 'Malay writer', a small number of coolies, policemen, and artificers, and a boatswain for the wharf. This was a smaller establishment than any that the Dutch had maintained at Bandjermasin. There was no military force whatever. ${ }^{27}$

Ostensibly, the settlement had a threefold purpose: to assist in the campaign against Malay piracy, to regulate the trade of southern Borneo and, in the confident phrase of the time, "to effect the general ends of civilization". These were the reasons given out in public; privately, Raffles, at any rate, expected a great deal more from Bandjermasin. He hoped he was founding a settlement from which the British could not be dislodged even if Java were handed back to the Dutch; but this was naturally kept secret. ${ }^{28}$

Hare approached his new task with confidence, for he did not expect any difficulty in negotiating a treaty with Bandjermasin. The Sultan, after all, had been asking for British protection since 1809, and was unlikely to refuse any reasonable terms offered him. But Hare knew that the only chance of securing a permanent British foothold in Borneo (and so meeting Raffles' real requirements) lay in making the new settlement pay for itself, and pay for itself quickly. If once Bandjermasin became a charge on the revenues, like Penang or Bencoolen, there was no hope whatever that the East India Company would long agree to its being retained.

The immediate task, however, was to establish Great Britain's formal rights to possession and, on October 1st, 1812, after the usual protracted oriental preliminaries, the Sultan was persuaded to sign the desired agreement. By this 'Treaty of 1812', as it became known, the Sultan and Perngerans of Bandjermasin ceded to the East India Company "in

27 Raffles to Minto, May 1st, 1812. (Fac. Rec., Borneo, 1648-1814, Vol. I).

28 Memorandum by B. S. Jones, India Board, 1824 (n.d.). (Dutch Records 'A', No. XIII). 
full rights of sovereign jurisdiction" the former Dutch forts (Tatas and Tabanio), the Dyak provinces of southern Borneo, and most of the districts and petty kingdoms on the South and East Coasts which were either practically or theoretically subject to them. The Sultan was released from all treaty or other obligations to the Dutch Government, and it was specifically provided that the document now being signed bore no relationship to "the events which have subsequently placed the Eastern Possessions of that Government under the British Empire". Raffles guaranteed to maintain the Sultan in his title and hereditaments, and to defend him against all enemies "as well European as Asiatic". For this purpose "an adequate force of light armed vessels" would be stationed off Bandjermasin. Any surplus in the revenues was to be divided equally between the Sultan and the Java Government, and no taxes, tolls or duties were to be levied by any local authority without the Resident of Bandjermasin's consent. The pepper monopoly would be continued and Government received the right to cut timber and mine gold and diamonds in all but a few places in the Sultan's dominions. Lastly, the Sultan was not to appoint his chief ministers without previously obtaining the approval of the Lieutenant-Governor of Java. ${ }^{2 \theta}$

In no important respect was this Treaty different from the contracts which had earlier bound Bandjermasin to the Dutch and, at first sight, Alexander Hare seemed to have gained a considerable diplomatic success. The Sultan had been induced to part with sovereign rights to a vast territory, and had received only vague promises of protection in exchange. In reality, however, the Treaty of 1812 meant very little. On his past showing the Sultan was not likely to abide by a 'scrap of paper' longer than served his immediate purpose. Moreover, most of the territories he 'ceded' so generously had only the haziest connections with his capital, and his Government had not exercised control over them for many years. He was therefore quite satisfied with his side of the bargain and, for the moment at any rate, the British were satisfied with theirs. The Java Government Gazette announced that $\mathrm{Mr}$. Resident Hare had been "hailed throughout His Highness' dominions as the deliverer of that once powerful kingdom".30

Alexander Hare, Resident of Bandjermasin, was a very remarkable

20 Treaty of October 1st, 1812. (Java Secret Consultations, December 17th, 1812. Fac. Rec., Borneo, 1648-1814, Vol. 1).

30 Issue of December 12th, 1812. 
man - even by the standards of the Eastern Seas, which harboured many strange characters in the early days of the nineteenth century. Plausible, unscrupulous, and ambitious, he had an exceptional talent for making his superiors believe in his sincerity and in the vague, grandiose plans he brought forward. The desire of his life was to found a kingdom of his own where he could luxuriate in oriental splendour surrounded by slaves and ladies of the harem. ${ }^{31}$ Why he picked on Bandjermasin as a suitable place for the realization of such dreams is not known. Probably he had heard exaggerated reports of its possibilities from Bornean prahu captains who called at Malacca in the days when he was a merchant there. A visit he made to Borneo in 1809 on Lord Minto's instructions may have suggested to him that the invitingly fertile lands near the town of Bandjermasin gave him the scope he needed. Whatever his original reasons were, however, Hare realized that the position he was in as Resident gave him a unique opportunity of gaining his own private ends as well as advancing the interests of Government; and on October 1st, 1812 (the same day that the Government Treaty was signed) he obtained from the Sultan of Bandjermasin a tract of land south of the capital, 1,400 square miles in extent, to be held by himself and his assigns "in full sovereignty and for ever". 32

This windfall did not occasion any surprise, or even any immediate comment, in Batavia. For one thing, Hare had been granted permission to engage in trade as one of the conditions of his appointment, and it could be argued that possession of territory was a legitimate extension of that right. There was also a better chance of the pepper trade flourishing if one man combined the duties of Government representative and private owner of the chief pepper gardens. Raffles made only one stipulation: Hare could hold his land only "on condition that he would always be ready to transfer his rights to Government, on a fair remuneration for improvements, should they at any time require it".33

The truth was, as the Government of Java well knew, that had it

31 John Clunies-Ross once said of him: "He appears to be.... superficially clever, but vacillating and indecisive in character, and his greatest feature was his licentiousness in regard to all bodily indulgences". (Quoted by John Scott Hughes, Kings of the Cocos, p. 26).

32 Act of Cession by the Sultan of Bandjermasin, 24 Ramadan 1227. (Quoted in $\mathrm{P}$. H. van der Kemp, 'Het afbreken van onze betrekkingen met Bandjermasin onder Daendels en de herstelling van het Nederlandsch gezag aldaar op den In Januari 1817', $B T L V, 1898$, p. 108, and in Gibson-Hill, op. cit., p. 30).

33 'Memorandum respecting the complaint preferred by Mr. Hare....', (Dutch Records 'A', No. 12). 
not been for Alexander Hare, a British settlement at Bandjermasin might never have been possible. It was Hare whom the Sultan had originally invited to establish himself there, not the East India Company. When Hare had first approached Raffles, it was to secure Government support for a step he felt he had a right to take on his own account, with or without official approval. In the offer made by the Sultan to Hare, Raffles saw an opportunity to invest the enterprise with the authority of Government and "with the view of establishing a permanent connection". Indeed, the Java Government felt under an obligation to Hare for his consenting to accept the appointment of Resident at all. An official position involved him in a "sacrifice of time and fortune". As a merchant he had no inducement to enter the service other than to obtain the support which a Government cloak of protection would give to his private ventures, and this fact, Raffles considered, "must have prevented his engaging in the undertaking unless allowed to follow at the same time his Commercial Pursuits". ${ }^{34}$

Having acquired his private empire in Borneo, Hare set to work to make it pay. He seems to have had plenty of money, both his own and the Government's; and he never worried greatly about distinguishing between the two. ${ }^{35}$ His intention was to grow export crops, mainly rice and pepper, on his own land, and to exploit the Company's territory by mining and collecting jungle produce. $\mathrm{He}$ also wanted to make Bandjermasin independent of Java salt by constructing a proper salt works at Tabanio. ${ }^{36}$

These plans might have worked out successfully had Hare not found that there was one commodity his money could not buy in Borneo labour. The small number of coolies the Sultan could provide for him was quite insufficient for his needs. A chronic labour shortage had existed in Bandjermasin for years. This was partly due to the preference of the Bandjar Malays for working on their own account (when they could persuade themselves that work was a desirable occupation), but mostly it was because a surplus male working population simply did not exist in the Sultanate - nor, for that matter, in any other part of Borneo. Hare soon realized that if the required labour force was to be obtained it must come from overseas. With this in mind, he returned to Java late in 1812 to confer with the Lieutenant-Governor.

s4 'Minute by the Lieutenant-Governor', February 11th, 1814. (Fac. Rec., Java, No. 40).

35 Gibson-Hill, op. cit., pp. 44-5.

38 'Extracts from a Journal kept by John Clunies-Ross', forwarded by Ross to Raffles on January 17th, 1825. (India Office Library MSS Eur. C. 36). 
The outcome of their deliberations was a series of circulars sent to British residents in Java urging them to recruit a labour force for the new British settlement at Bandjermasin. The first of these circulars, dated March 6th, 1813, instructed all residents to "ascertain if there be any healthy Buginese or others, not natives of Java, who, having been in the Military Service of the late Government or otherwise, and being now out of Employ, are reduced to want or distress". Likely applicants were to be "assisted in proceeding to Bandjermasin when the favourable Monsoon arrives". The residents were also requested to use their influence through the Javanese Regents "to discover any persons who, with their families, would be inclined to adopt the same plan". No compulsion was to be used in execution of these orders; prospective emigrants were to be assured that they would be looked after by the Resident of Bandjermasin himself and given their own land to cultivate on arrival.

The first circular produced little or no result, however, and the scheme did not long remain on a voluntary basis. The next, issued on May 31st of the same year, adopted a harsher tone. "All men and women", it said, "who have not a regular, visible mode of subsistence, and are observable for conduct rendering it expedient for the Tranquillity of the Country to remove them, may be sent [to Bandjermasin]". These new orders were applicable to ordinary, native-born Javanese, not, as before, only to undesirable bands of ex-soldiers who were wandering about the countryside and terrifying the population. The residents were also to make available "spearmen of good character" who would be sent to Bandjermasin for limited tours of duty as native police. And, most important of all, Bandjermasin was declared to be a penal settlement for convicts guilty of minor offences, and the population was to be swelled still further by the granting of permission for the wives and children of offenders to accompany their husbands or fathers.

These orders, slightly modified by subsequent circulars, lasted until the end of 1815 , by which time three separate classes of persons had gone, or had been sent, to Bandjermasin. There were, first, convicted felons, on sentences varying from a few months to transportation for an undefined period. Next, there were vagrants, vagabonds, and general undesirables, most of whom were under a technical 'sentence' of banishment. Lastly, there was an oddly-assorted collection of more or less bona fide free emigrants, who ranged from those who took the advice of a propaganda leaflet written by Hare extolling the virtues and 
salubrity of Bandjermasin, to those who responded to a Government memorandum drawing attention to the sad plight of offenders there, "who had hitherto laboured under much severity from the want of a proportionate female population". 37

Altogether, upwards of 3,200 persons were carried to Bandjer$\operatorname{masin}^{38}$ (at a cost to Government of 25 rupees a head) to work in Alexander Hare's rice fields and pepper gardens. The great majority of them did not go of their own free will. Many were branded as vagabonds and transported merely on the recommendation of the local Regents or Javanese police officers. There were few official investigations into individual cases, and incompetent evidence was often admitted in the inquiries that did take place. Many unfortunates listed as volunteers were undoubtedly 'over-persuaded'; many women were enticed aboard Hare's ships and even aboard Government gunboats to be 'married' later to the 'colonists' at Bandjermasin. ${ }^{39}$

A settlement composed chiefly of the least desirable elements in Javanese society could not be said to have made a promising beginning. Rare organizing powers would be needed at the top if Bandjermasin was to flourish and, although Hare certainly had a marked talent for getting his own way with his superiors, he had no experience of planting and little administrative ability. Within a short time the condition of his settlers was pitiable. Food and clothing were inadequate; no more than a start had been made in laying out the pepper gardens when most of the labour available was absorbed in erecting buildings for the Resident's personal use; and attempts at gold and diamond mining collapsed before any profits had been made. ${ }^{40}$ The Sultan complained that the rowdier members of the community at the pepper gardens had become so "afflicted by God" that their excesses had driven out the original inhabitants of the area.

Thus, by 1815, the first attempt of the British Government of Java to gain a permanent foothold on the coast of Borneo against the time when its own existence would cease seemed to be heading towards disaster. The occupation of Bandjermasin, however, was only one part

37 The texts of the Government memoranda and circulars quoted in this and the two preceding paragraphs are included in a letter from John Fendall to the Marquis of Hastings of September 25th, 1817. (Dutch Records 'A', No. 12).

38 Many guesses have been made at this figure. I have accepted the total calculated by the British Commissioners sent to Bandjermasin in 1817. (Ibid).

39 Fendall to Hastings, September 25th, 1817. (Ibid).

10 J. C. Baud, 'De Bandjermasinsche afschuwelijkheid....', BTLV, 1860, pp. 4-5. 
of a much larger plan. The Lieutenant-Governor and his Council had already focussed their attention on other, and potentially more valuable, parts of Borneo, the west and north-west coasts. Here, the three most important native states, Pontianak, Sambas, and Brunei, though individually less influential than Bandjermasin, had a bigger combined population and a more vigorous overseas trade. Above all, western Borneo contained a number of powerful, independent, and prosperous Chinese gold-mining communities.

The first Chinese miners (as distinct from traders) who came to the West Coast of Borneo were probably those brought from Brunei by the Panembahan of Mampawa between 1740 and 1745. The Sultan of Sambas soon followed the Panembahan's example, and Chinese settlements grew up at Seminis, Larah, Montrado, Mandor, and other places. Initially, heavy restrictions were laid on these communities by the Malay potentates: the miners were not permitted to engage in agriculture nor carry firearms, they had to pay an annual tax of $f 32,000$ in gold, Dyak headmen were placed over them as 'supervisors', and they were forced to buy everything they needed from the Malays at exhorbitant prices. By 1760 , however, they had become strong enough to throw off the Malay yoke, and from then onwards lived in independent self-governing communities, known as 'kongsis'.

In the days of the Dutch East India Company immigration from China to western Borneo was discouraged, and the greatest influx of miners occurred after 1791, when the Company's forces were withdrawn from this area. By 1812 there may have been a total population of 30,000 , most of whom were Hakkas, Hokkiens, and Cantonese. Raffles estimated that the output of the West Coast gold mines in that year was worth $\$(\mathrm{Sp}) 4,744,000$. It seemed obvious to him that there were great economic possibilities in western Borneo and he set about the task of bringing it within his Government's sphere of influence. ${ }^{41}$

His own direct interest in Pontianak and Sambas had been aroused while he was still stationed at Malacca as the Governor-General's 'Agent with the Malay States'. Then he had numbered among his many duties

41 S. H. Schaank, 'De kongsi's van Montrado', TTLV, 1893, pp. 506-7 and 517. P. M. van Meeteren Brouwer, 'De geschiedenis der Chineesche districten der Wester-afdeeling van Borneo van 1740-1926', De Indische Gids, 1927, ii, pp. 1057-8. D. W. C baron van Lijnden, 'De verhouding in welke het Gouvernement staat tot de Chinezen en Dajaks op de Westkust van Borneo....', TvNI, 1853, i, p. 171. Sir Stamford Raffles, The History of Java, Vol. i, pp. 236-7. 
the task of protecting British shipping in the Eastern Seas. "Having learned that the ship Commerce", he wrote to Lord Minto soon after his appointment, "had .... been disabled on the coast of Borneo by the loss of her rudder, and had drifted upon a small island.... I addressed a letter to the Sultan of Pontianak requesting his assistance. The Sultan, in his reply, stated that this vessel had been seized by the pirates of Serawa [Sarawak], a small dependency on Borneo proper [Brunei] in conjunction with those of Sambas". ${ }^{42}$ To find out what had happened to the Commerce and a number of other missing ships and to establish an 'observation post' on the West Coast of Borneo, Raffles sent Mr. F. Burn to Pontianak early in 1811 as his political and commercial agent.

On arrival, Burn discovered that the Raja of Sarawak had indeed captured the Commerce, had plundered and burnt her, and had sent the Captain and forty-five of her crew as slaves to Brunei. The cargo had been sold, and the second mate put to death "in a private manner". Before burning the ship, the Raja had written to the Sultan of Pontianak offering her for sale, but this had been refused. Burn told Raffles that he himself had seen the correspondence. ${ }^{43}$

The fate of the Commerce and the loss, shortly afterwards, of the brig Malacca (from which the Sultan of Sambas stole a cargo of tin valued at $\$ 14,000$ ) give some indication of the seriousness of the pirate menace on the West Coast of Borneo at this time. The number of ships lost through various forms of piratical outrage had been growing steadily for some years past and, paradoxically enough, this increase was due to British dominance at sea. When the Dutch navy was driven from the Eastern Seas in 1808, its police vessels disappeared at the same time, and the Royal Navy, loath to accept additional burdens while the European War was still in progress, did not take the place of the Dutch as the policeman of the Archipelago, with the result that piracy flourished almost unchecked.

Contemporary observers were agreed that at this period the headquarters of the marauders of the West Coast of Borneo was the Sultanate of Sambas. Most of the pirate chiefs in the neighbourhood had business or family connections there, and the dreaded Lanuns, the most powerful sea rovers in the Indies, used it as a base during certain times of the year. The claim of Sambas to pre-eminence in this

42 Sophia Raffles, op. cit., pp. 46-7. John Leyden, op. cit., p. 95.

43 Burn to Raffles, February 12th, 1811. (India Office Library MSS Eur. E 109). 
respect was undoubted, but it seems likely that its greatness had to some extent been thrust upon it.

The decay of the Sultanate of Soekadana during the course of the eighteenth century had left the two states of Sambas and Pontianak rivals for the control of western Borneo. Sambas should have possessed a decisive advantage in this struggle, since the majority of the West Coast Chinese lived in its territory; and, as the Chinese were by far the largest consumers of taxable goods, the revenues of Sambas should have been swelled accordinglv. But Pontianak, largely because of the popularity of its harbour with European merchant skippers, succeeded during the early part of the nineteenth century in attracting most of the West Coast's overseas trade. The result was that by 1812 more goods were being imported through Pontianak for Sambas Chinese than were coming in through Sambas itself, and Pontianak prospered as the trade of Sambas fell away. Thus, apart from the natural inclination of the people towards a life of plunder and violence, it was desperation and a desire for revenge against its rival that earned for Sambas the reputation of being the worst of the "irregular and piratical ports" on the whole coast of Borneo. When Raffles wrote to the two most important Sultans on the West Coast about his wish to end the evil of piracy, it is therefore easy to see why the Sultan of Pontianak was ready to listen to him, while the Sultan of Sambas was not. The former knew that his greatest hopes of profit lay in legitimate trade; the latter derived his main revenues from piracy and extortion.

British merchants were inclined in any case to favour Pontianak rather than Sambas. They had become accustomed to using the port during the days of Dutch rule "as an Entrepot for the clandestine importation of opium and Piece Goods into Java"."4 When, after his arrival in Java, Raffles turned once again to the problems of Borneo, he was therefore in no doubt about the best policy to pursue on the West Coast. He would offer a guarantee of protection to the Sultan of Pontianak and the 'piratical state of Sambas' would be rigorously suppressed.

Accordingly, a naval expedition under the command of Captain J. Bowen, R.N., sailed against Sambas in October 1812. Bowen's orders were to destroy the town and port completely, for Raffles wanted an example made of Sambas so that other pirates in the Archipelago might profit from its fate. On entering the river which leads up to the

44 'Memorandum relative to the States of Sambas and Pontianak....', December 20th, 1814. (Fac. Rec., Java, No. 65). 
town, however, the attackers came under heavy fire from shore batteries and from the guns of a Lanun pirate squadron which chanced to be sheltering in the river-mouth at the time. ${ }^{45}$ It had been assumed by the authorities in Java that a display of force would be sufficient to bring about a capitulation; only a hundred soldiers accompanied the expedition, and no preparations had been made for operations on land. ${ }^{46}$ Finding himself without any means of outflanking the guns, Bowen was compelled to make an ignominious withdrawal. The effect of this fiasco on British prestige in Borneo may be imagined, but because the resources for a stronger expedition were not immediately available, the 'public chastisement' of Sambas had to be postponed. ${ }^{47}$

Raffles had already set out the main points of his policy for the West Coast in a dispatch of April 6th, 1812. There were, in the Lieutenant-Governor's opinion, too many "irregular States" in Borneo. Sambas was in a particularly evil condition; the Sultan was in his dotage and his illegitimate son, Pěngeran Anom, who was "an open pirate", had full charge of affairs. Eventually, Raffles considered, it should be possible to bring all the Borneo rivers under the British Government but, until Sambas could be more effectively dealt with, the first thing to do was to elevate the Sultanate of Pontianak to such a position that it could dominate the whole coast. ${ }^{48}$

When approached on the subject of a formal treaty with Great Britain, the ruler of Pontianak made no demur. On the contrary he welcomed the prospect of British protection and himself suggested that a British establishment should be placed at his capital. "I request", he wrote to Raffles, "the Honourable Company may divide with me the land-rent and the Port Duties, placing twenty-four soldiers with an English flag at Pontianak". He added an imposing list of demands: for assistance in collecting tribute from the Chinese, for support against Sambas in a current boundary dispute, and for an assurance that the trade of Sambas would not be permitted to revive. "Above all things", he concluded, "I trust the English Company will not consider the connection now to be formed as proceeding from any former alliance with the Dutch, lest Pontianak might again come under their rule when a

45 Sir Spenser St. John, The Life of Sir James Brooke, Rajah of Sarawak, p. 21 (quoting the evidence of an eye-witness).

46 John Bastin, 'Raffles and British Policy in the Indian Archipelago, 18111816, JRASMB, May 1954, p. 94. H. D. Levyssohn Norman, De britsche heerschappij over Java en onderhoorigheden (1811-1816), p. 101.

47 Raffles to the Secret Committee, June 30th, 1813. (Fac. Rec., Java, No 60).

48 Raffles to Hare, April 6th, 1812. (Ibid). 
peace takes place in Europe, because the Dutch have long since entirely released Pontianak from any allegiance towards them".49

Such proposals must have been very attractive to Raffles, but he was not at this time considering the possibility of British settlements in Borneo in addition to Bandjermasin. His aim was the extension not of territory, but of trade; in March 1813 he sent John Hunt to Pontianak as his Commercial Agent; ${ }^{50}$ and, because no trade could flourish on the West Coast while Sambas still exercised its pernicious influence, he determined to settle with this great pirate stronghold once and for all.

The second British expedition to Sambas was considerably better planned than the first. A strong military force, commanded by Colonel Watson of the 14th Regiment, arrived off the river-mouth on June 23rd, 1813 , in company with a naval screen provided from Malacca. A letter was sent to the Sultan demanding the surrender of the pirate chief, Perngeran Anom, but no answer was received. The military detachment thereupon landed on an unprotected part of the shore and, after making a successful assault on the river batteries from the rear, captured the whole of the Sambas fortifications in a half-hour battle. A hundred and fifty of the enemy were killed and there were only eight fatal British casualties. Pĕngeran Anom, however, made good his escape into the interior. ${ }^{51}$

Raffles now believed that the way was clear for the unfolding of his Bornean policy. His first step was to declare a general blockade of all Bornean ports except Bandjermasin, Pontianak, and Brunei. No European ship was to be allowed access to any port except these three, though the native coastal trade was permitted to continue unmolested. The reasoning behind these drastic restrictive measures seems to have been as follows: Raffles knew he would never have naval forces at his command strong enough to enforce a real blockade of all pirate outposts in the vast island of Borneo, and he therefore decided to 'canalize' European trade on the three major ports where there was at least some hope of protecting it. Other ports in the Archipelago were similarly

40 Sultan of Pontianak to Raffles, 18 Rabi' I, 1228 (1813). (Fac. Rec., Java, No. 60). 'Memorandum relative to the States of Sambas and Pontianak....' (Fac. Rec., Java, No. 65).

$50 \mathrm{~F}$. de Haan, 'Personalia der periode van het Engelsch bestuur over Java 1811-1816', BTLV, 1935, p. 585.

51 'Report of Colonel James Watson, July 3rd, 1813'. (Fac. Rec., Java, No. 60. Also printed in Major William Thorn, Memoir of the Conquest of Java...., pp. 327-30). General Letter of the Government of Penang, June 30th, 1813. (Fac. Rec., Straits Settlements, No. 185). 
closed, and Raffles subsequently claimed that the broad aim he had in view was the reduction of the unfavourable trade balance of Java. "The adoption of this system", he wrote to the Supreme Government of India, "with the encouragement of the native trade to import the produce of the dependencies into Java, seems all that is necessary to tranquillize the Eastern Seas and at the same time enables Java in some degree to reduce the balance of trade which now stands so much against it". .2

Secondly, Raffles appointed Captain Robert C. Garnham to be his 'Special Commissioner to the Borneo Ports and Macassar', and sent him on a tour of the West Coast of Borneo in August 1813. The purpose of this mission was to encourage legitimate trade, and to hold up the spectacle of the fate which had overtaken Sambas as a warning to all piratical sultans and rajas on the coasts. "The intentions of Government", Raffles told Garnham, "are decidedly not to leave eventually a Single Pirate on foot in the Eastern Seas". ${ }^{33}$

On his arrival at Sambas on September 10th, 1813, Captain Garnham proclaimed a general amnesty and sent a letter to the Sultan offering to restore him to the throne on condition that a British resident was appointed to advise him. Continuing his journey up the coast, Garnham admonished the Raja of Sarawak, also by letter, ${ }^{54}$ and then went on to Brunei to interview the Sultan. After announcing the purpose of his visit, the British Commissioner warned the Sultan that he must circulate due notice of the intended blockade of all the North Borneo ports but his own, and that if any of his subjects should try to evade the new regulations the support of the British Government might be counted on to suppress them. "At this", Garnham later reported to Raffles, "the Sultan and all his Pĕngerans all expressed themselves much obliged and pleased".55

On his return to Sambas the Commissioner found that the letter he had addressed to the Sultan had produced the desired results. On October 24th, aboard H.M.S. Malacca in Sambas Roads, His Highness was restored to his ancestral rights and a treaty of perpetual peace was signed by which the Government of Java acquired a protectorate over

62 Letter of May 12th, 1813. (Fac. Rec., Java, No. 60).

53 'Instructions to Capt. Garnham, August 10th, 1813'. (Fac. Rec., Java, No. 60).

54 Similar letters stressing the evils of piracy were addressed by Raffles to the Sultans of Koetei and Pasir on the East Coast. Their Highness' replies if any - do not appear to have survived.

55 'Report of Capt. Garnham to Charles Assey, Sec. to Govt., Java .... November 15th, 1813'. (Fac. Rec., Java, No. 40). 
the dominions of Sambas, and power to alter the succession to the throne and make all necessary arrangements with regard to revenues and trade.

Captain Garnham's diplomatic successes on the West Coast represent the high-water mark of Raffles' Bornean policy. In eighteen months the Lieutenant-Governor had founded a settlement at Bandjermasin, begun the work of suppressing piracy, arranged for the appointment of British residents at Pontianak and Sambas, and brought the Sultan of Brunei into the British fold. The four largest native states in the island either recognized British sovereignty or looked to the British Government for protection. Raffles' hopes for the future were recorded in a minute he wrote for the Council of Java in February 1814: "The great Island of Borneo, the Sulu Islands, Lingga and Riouw, Bali, the East Coast of Sumatra, Siam, Cambodia, Cochin China, etc. are free from all connection with the former ruling Power in these Seas, and want but attention of a liberal and enlightened Government to add extensively to the Commerce of India and to the permanent political ascendancy of the British authority and influence in these Seas".56 Unhappily for the Lieutenant-Governor of Java, however, the destiny of British rule in the East Indian Archipelago was to be decided not at Batavia, but in Calcutta and in London.

During all this time Raffles had been conducting what amounted almost to a private campaign for the extension of British influence in Borneo and other parts of the Indian Archipelago. He was able to do this because of the comparative isolation of his position as LieutenantGovernor of Java. In Raffles' day, servants of the East India Company in distant outposts were often cut off for months (sometimes for years in time of war) from contact with higher authority. This was not due to any deliberate policy on the part of either the Directors in London or the Supreme Government of India; they had no wish to grant independence to subordinates in Batavia or Penang. Rather it was the result of the uncertainty and irregularity of sea communications in the early part of the nineteenth century. Raffles and his contemporaries were often obliged to take far-reaching decisions on their own account for sheer lack of appropriate instructions. Raffles himself sometimes acted in defiance of orders which he considered, rightly or wrongly, to

56 Minute by the I.ieutenant-Governor, February 11th, 1814. (Fac. Rec., Java, No. 40 ). 
be out of date or irrelevant. It was not until the advent of the steamship and the telegraph that the Home and Indian Governments were able to exert more than a remote and belated control over their possessions in the Far East.

It is true that Raffles was more eager to take responsibility for great decisions upon himself than most men in his position would have been. But there was good reason for this. He knew that so long as his friend and patron, Lord Minto, was Governor-General of Bengal his plans were certain of a sympathetic hearing; and also (more important in view of the slowness of communications) that he could be sure of Minto's support on those occasions when he had to act first and ask permission afterwards. Indeed, many of the schemes for which Raffles has been given the credit (or the blame) were more Lord Minto's than his own. Alexander Hare's establishment at Bandjermasin, for example, was undertaken on Minto's personal instructions, and Raffles' West Coast policy certainly did not go farther than the Governor-General's expressed intention. In September 1810 Minto had stated his general views in these words: "From the first decided establishment of the French Authority and even influence in Holland, I have regarded the expulsion of the Dutch power from Java and the Eastern Seas generally as one of those essential objects of national policy on which British arms might perhaps be more beneficially employed than on any other". ${ }^{57}$ While the war in Europe lasted and while Minto continued at the head of affairs in India, the Lieutenant-Governor of Java's position was secure. But when, on October 4th, 1813, a new Governor-General, Lord Moira, arrived in India, Raffles soon found he could no longer count on an almost automatic acceptance of his views.

The arrival in Calcutta of a copy of Captain Garnham's Borneo instructions produced the first sign of a new coolness on the part of the Supreme Government. In January 1814, the Secretary to Government at Fort William sent off a hurried dispatch to Batavia halting all plans for Borneo until more time could be given to the whole problem of the Eastern Seas. Governor-General Lord Moira, the dispatch implied, needed time to recover his breath. For the time being, His Excellency would confine himself to a single observation: "The measures indicated to be in the contemplation of the Government of Java .... are liable to involve ultimately so heavy an expense, such a waste of Troops, and

${ }^{57}$ Lord Minto to General Abercrombie, September 3rd, 1810. (Quoted in M. L. van Deventer, Het Nederlandsch gezag over Java en onderhoorigheden sedert 1811, p. ii. My italics)。 
such important Political consequences as to require that they should not be engaged in without the previous consent of this Government". ${ }^{58}$

Raffles, meanwhile, sensing that a clearer presentation of his views was necessary if they were to make any headway in Calcutta, had drafted a lengthy memorandum embodying the main points of his case for the Governor-General's consideration. He based his arguments on the essential need, as he saw it, for separating British interests in the Archipelago from those of "the conquered colony of Java". Dutch connections with Borneo, Raffles contended, had been formal only, where they had existed at all. The native states in the island had repeatedly indicated their desire for "the protecting connection of the British power"; and it would be folly to allow them to share the political fate of Java. A line should be drawn to distinguish "the States in connection with the British Government exclusively from those which have been dependent on the [former] ruling power". To carry out his policy, Raffles recommended that he himself, or any other suitable authority "residing to the Eastward" should be made "Agent to the Governor-General" in the Eastern Seas, with the duty of preventing "the possibility of British Policy and Arms being confounded and lost in any arrangement that may eventually take place". ${ }^{50}$

By the time this memorandum reached Calcutta, Lord Moira had had time to consider the position more fully. In a dispatch of May 28th, 1814, he examined Raffles' arguments and demolished them one by one. Supposing Java were retained by the East India Company, he wrote, there would then be no need for further British establishments in the Eastern Seas; British commerce would continue to be in the ascendant and the necessary protection for shipping against foreign encroachment and the dangers of piracy could be given from Java. If on the other hand Java and its dependencies were to be returned to their former owners, the Dutch would naturally view British settlements in their immediate neighbourhood with jealousy and suspicion. The result would be a condition of perpetual disputes, "our commerce would be designedly obstructed on all occasions, and a resort to arms might become necessary to resent and to repress the wrongs done to individuals". It was quite wrong, Lord Moira argued, to take advantage of the temporary absence of the Dutch to advance policies inimical to

58 Sec. to Govt., Fort William, to Sec. to Govt., Java, January 22nd, 1814. (Fac. Rec., Java, No. 40).

50 Minute by the Lieutenant-Governor, February 11th, 1814. (Fac. Rec., Java, No. 40). 
their interests. Further, he did not believe that the princes of Borneo were really anxious for British protection and, in any case, the process of 'civilizing' them would cost a great deal of blood and money. He was prepared to give a grudging approval to the continuance of the Bandjermasin settlement, but insisted that all other plans for Borneo be discontinued immediately; British residents on the West Coast he considered "quite unnecessary"; and no close arrangements were to be made with the Sultan of Brunei. As for the policy of confining the trade of Borneo to three ports, even if this were sound (which Moira did not for one moment admit), the Government of Java had no power to enforce such restrictions and no justification for attempting to do so. All plans for blockading Borneo were to be cancelled forthwith. ${ }^{60}$

These instructions placed Raffles in a difficult position. He had to abandon his 'grand design' for Borneo and at the same time try to keep faith with the native princes to whom he had held out such large hopes of support. In August 1814 he sent an agent, Captain Macdonald, to Sambas to grant a pardon to Pěngeran Anom. Less than a week after Pĕngeran Anom had made his submission, the decrepit Sultan of Sambas died; and on September 17th the acting regent, the Pèngeran Běndahara, wrote to Raffles requesting the appointment of a British official "to reside with us at Sambas for the purpose of carrying the orders and wishes of Government into effect and in order that we may duly receive and rightly comprehend the same". ${ }^{61}$ Raffles must have found this request both galling and frustrating, for he knew that, had he been authorized to comply with it, he might have been able to prevent the Sultanate of Sambas from lapsing into piracy again. As it was, he was compelled to break off all relations with Sambas and recognize the archpirate, Pĕngeran Anom, as the new Sultan, since there was no one else capable of preserving even a semblance of government there. He can have derived small consolation from a Supreme Government dispatch of November 5th assuring him that the Governor-General "entirely concurred in the propriety of opening a friendly communication with the Chief of Sambas". ${ }^{62}$ No further attempts were made by British authorities in Java to enter into treaty arrangements with the Bornean

00 Sec. to Govt., Fort William, to Sec. to Govt., Java, May 28th, 1814. (Fac. Rec., Java, No. 41).

61 Pèngeran Bèndahara of Sambas to Sec. to Govt., Java, September 17th, 1814. (Ibid).

2 Sec. to Govt., Fort William, to Sec. to Govt., Java, November 5th, 1814. (Ibid). 
princes, though Mr. Bloem, the Deputy Resident at Pontianak, retained his appointment until April 1815. ${ }^{63}$

There was never any real chance of Raffles' hopes of British dominion in Borneo being realized. The sudden rebuff he received from the Government of India represented only one aspect of something more fundamental - the reassertion of the East India Company's traditional policy of 'trade, not territory' east of the Straits of Malacca. The Directors in London had never given their whole-hearted approval even to the temporary annexation of the Indies, ${ }^{84}$ and they did not believe that the commercial supremacy their ships had attained in the Far East would be endangered by the return of the Dutch to the Indian Archipelago. Moreover, the Company's experiences in Java to date gave no indication that the retention of the island would be financially worth while. Expenses had been in excess of revenue all through the years 1811 to 1814, and the prospect of pouring funds into East Indian territories in the doubtful hope of obtaining far-off benefits made no appeal to the Court of Directors in London.

The British Home Government, too, had their reasons for favouring the return of the Dutch. As the war against Napoleon drew to a close, British Ministers, anxious to safeguard their country's security, turned their attention to the problem of re-establishing a strong Holland in Europe. It was clear that the stability of the new Kingdom of the Netherlands would largely depend on the prosperity it could derive from colonial possessions. The problem was, which of the Dutch colonies captured by British forces during the course of the war should be restored? The West Indian 'sugar lobby' in the House of Commons strongly urged the retention of Demarara, Essequibo, and Berbice. Naval authorities were loath to give up the Cape of Good Hope and Ceylon, the former because of its general strategic value, the latter because of its excellent harbour at Trincomalee. But there was no similar pressure group working for the retention of the East Indies; as territorial possessions, the islands of the Archipelago had no obvious contribution to make to an Empire that was based on sea power and existed for the benefit of trade; and the East India Company, the only authority likely to benefit from continued ownership of them, had already expressed its lack of interest in their fate.

63 De Haan, 'Personalia ....', p. 500.

64 Cf. the Secret Letter of the Court of Directors of October 25th, 1816. (Quoted in van Deventer, op. cit., p. 115). 
Such was the background of the Convention between Great Britain and the Netherlands which was signed in London on August 13th, 1814. This agreement laid down that "the Colonies Factories and Establishments which were possessed by Holland at the commencement of the late War, viz. on the 1st of January, 1803, in the seas and on the Continents of America, Africa and Asia, with the exception of the Cape of Good Hope and the Settlements of Demarara, Essequibo and Berbice" would be restored to Dutch sovereignty ${ }^{65}$ Britain ceded the island of Banka in exchange for the Dutch possessions on the Malabar Coast of India, and suitable arrangements were made for safeguarding the property of merchants and land-owners likely to be affected by the change. But of the British settlement of Bandjermasin in Borneo, with whose ruler a treaty had been concluded only two years before, guaranteeing that his dominions would in no circumstances be restored to the Dutch, no mention was made.

It is improbable that Lord Castlereagh, who signed the Convention of 1814 on behalf of Great Britain, would have allowed the terms of this treaty to influence him, had he been aware of its existence. But it is surprising nevertheless to learn that, at this time, not even East India House had received advice of any of Raffles' attempts to advance their interests on the coasts of Borneo. An East India House minute, written in $1818,{ }^{66}$ after noting that Raffles, when Lieutenant-Governor of Java, had "actually proceeded to conclude a treaty with the Rajah of Bandjermasin in Borneo", observed that "this and some other transactions of Sir T. S. Raffles with the Chiefs of Sambas and Pontianak did not come under consideration at home until after the Convention of August 1814, with the King of the Netherlands, had been concluded". The minute makes no attempt to explain why this was so. Probably the slowness of sea communications, the length of time taken to transmit information of this kind 'through the proper channels', and dilatoriness within East India House itself all contributed to the delay. Orders from the Secret Committee, in which the Treaty with Bandjermasin was "pointedly disavowed as an unauthorized and invalid act" were

05 Text of the Convention of 1814, Article I. (Fac. Rec., Java, No. 64). The Dutch were to resume control within six months of ratification by both parties. Ceylon, having been captured by British forces before January 1st, 1803, did not come within the terms of the Convention of 1814.

68 The minute is undated and unsigned and is included in a miscellaneous collection of East India House documents (Fac. Rec., Java, No. 64) dating from 1813 to 1820 . Internal evidence suggests the date I have ascribed to it. 
not issued until January 9th, 1815, and by this time, as we have seen, the Supreme Government of India, under Lord Moira's guidance, had taken matters into their own hands.

By the time Stamford Raffles was relieved of his appointment as Lieutenant-Governor of Java in 1815, a moribund and unproductive settlement at Bandjermasin was all that remained of his Bornean 'grand design'. The decision to dismiss him was based on the Company's disapproval of his financial and administrative policies in Java. So far as his actions in Borneo were concerned, Raffles was able to show that, during the early period of his rule, he had done no more than carry out Lord Minto's instructions and that, after Lord Moira's assumption of office, he had confined his jurisdiction to Java when ordered to do so. $^{.7}$

In 1824 Raffles described his past actions in Borneo in these words: "I will simply state, that the measures adopted with reference to this great and important island, had in view the opening its ports to general commerce and the final establishment of the British influence in Borneo, as far as might be necessary for securing that object. The Dutch, previous to the conquest of Java, had relinquished all title to interfere; and had it been an object with the British Government, the command of the whole of that great island was placed entirely at our disposal". ${ }^{88}$ It was naturally with some bitterness that the former Lieutenant-Governor looked back on his failure in Borneo. The prize had been within his grasp, he felt, and a great opportunity had been thrown away. Legally, there was much to be said for Raffles' views; so far as formal contracts with native princes were concerned, the Netherlands had no better title to possession of Borneo in 1815 than Great Britain. But morally, he was wrong; for the British Government to have taken advantage of an accident like the war-time annexation of Java in order to deprive the Dutch of all access to Borneo (which was what Raffles wanted) would have been wholly unjustifiable. In all his minutes and dispatches, Raffles placed a high value on Borneo; it remained to be seen whether the Netherlands Indian Government would profit from their newly-restored possession.

${ }^{67}$ Raffles to the Court of Directors, January 27th, 1816. (Fac. Rec., Java, No. 61).

88 Statement of the Services of Sir Stamford Raffles, p. 17. 


\section{CHAPTER II}

\section{THE RESTORATION OF DUTCH RULE}

When, in accordance with the provisions of the Convention of 1814 , the time came for the Dutch to take over Java and its dependencies from the English East India Company, King Willem I of the Netherlands entrusted this important and responsible task to three Commissioners-General, C. Th. Elout, Baron van der Capellen, and Rear-Admiral Buyskes. The departure of these officials from Holland was considerably delayed by Napoleon's escape from Elba and the subsequent crisis in Europe, but early in 1816 they reached Batavia at last and on August 19th of that year formally accepted the transfer of Java from John Fendall, Stamford Raffles' successor as British Lieutenant-Governor. Routine matters of administration occupied the Commissioners-General for a time, but before long they began pressing for the return of certain of the former Netherlands Indian possessions in the Outer Islands, including Borneo.

These requests were a source of some embarrassment to Fendall and his colleagues on the 'Board of Commissioners' (as the British authorities in Java were now called) for they were suffering from that lack of up-to-date instructions which experienced servants of the East India Company in distant stations had learnt to accept with resignation. Negotations concerning the transfer of the Java dependencies consequently made slow progress. It was perhaps inevitable that a change of sovereignty involving so large an area should have given rise to a certain number of misunderstandings and asperities, but neither side, Dutch or British, can have had any inkling of the bitterness that would ultimately be aroused by the apparently unimportant little settlement of Bandjermasin.

By 1816 the colony which had been established four years previously by Alexander Hare was approaching collapse. Accounts were chaotic, trade had declined, and the production of rice and pepper had ceased almost entirely. More serious still, the settlement was fast becoming a heavy charge on the finances of the East India Company. From the beginning of 1812 to April 1816 the Company paid out no less than 
649,685 rupees in a vain endeavour to bring prosperity to Bandjermasin, and received only 92,915 rupees in return; nearly half the total deficit of 556,770 rupees (about $£ 60,000$ ) was incurred during 1815 and the first four months of $1816 .^{69}$ The Company realized, moreover, that once the greater part of the Eastern Archipelago had again become Dutch territory, a lone British outpost on the South Coast of Borneo would have no strategic and little commercial value; in time of war it would be an embarrassment, and in peace its trade would always run the risk of being strangled by the powerful commercial interests along the north coast of Java.

In 1816 Bandjermasin was therefore viewed by the East India Company with much the same jaundiced eye as it had been by Marshal Daendels in 1809. There was no hesitation on the Company's part about abandoning an economic liability, just as there had been none on Daendels'. As a matter of policy the decision was easily taken, but difficulties soon crowded in on Lieutenant-Governor Fendall when he began to put his orders into effect.

Fundamentally, the Anglo-Dutch controversy over Bandjermasin was due to British insistence that this particular settlement must be considered separately from other parts of the Indies. The Dutch were unwilling to make such a distinction. When, on June 27th, 1816, the British Lieutenant-Governor forwarded to the Dutch CommissionersGeneral a list of places which were, in his view, fit subjects for negotiation between their two countries, Bandjermasin was not mentioned, ${ }^{70}$ and the Commissioners-General assumed, wrongly, that this was an oversight. ${ }^{71}$ They took their stand on the first article of the Convention of 1814, which had declared that all territories in the Eastern Seas which were Dutch possessions on January 1st, 1803, were to be restored to the Government of the Netherlands. The Dutch therefore put two questions to the British Lieutenant-Governor: was it not a fact, they asked, that Bandjermasin had been a Dutch possession in 1803? And was it not also a fact that this same colony was now in British hands? Since the answer to both these questions must be 'Yes', they

69 'Account Current of the Charges of the Settlement of Bandjermasin', compiled by the Accountant's Office, Batavia, September 13th, 1816. (Quoted in Baud, op. cit., p. 24).

70 Fendall to the Commissioners-General, June 27th, 1816. ('Register der Handelingen en Besluiten van Commissarissen Generaal over Nederlandsch Indien', 1 Mei tot 30 Augustus 1816).

71 Commissioners-General to Fendall, July 4th, 1816. (Ibid). 
could see no bar to the transfer. The Convention itself, they argued, had made no exception with regard to Bandjermasin, and it ill became those, whose duty it was merely to put that agreement into execution, to find one. ${ }^{72}$ "The continued refusal", they added, "of the former provisional government of Java .... to deliver [Bandjermasin] over to the Netherlands Government would be a positive and direct infraction of the rights which this Government has acquired by the treaty of the 13th August 1814". ${ }^{73}$

But the British Lieutenant-Governor could not view the matter in such clear-cut, logical terms, since he had to take other considerations besides these into account. In the first place, his Government was still bound by the terms of the Treaty negotiated by Alexander Hare in 1812 , which had declared that in no circumstances would Britain hand Bandjermasin over to any other European power. Fendall's problem here was to reconcile his country's conflicting obligations under these two treaties. The Convention forbade him to retain Bandjermasin; the Treaty of 1812 denied him the right to hand it back. Nor did any of the official instructions he had so far received give him any assistance; neither the Prince Regent's 'Warrant for the Restitution of the Colonies' nor the orders of the Supreme Government of India contained any reference to Bandjermasin at all.

Secondly, Fendall had to contend with a change in attitude on the part of the Sultan. For years His Highness had been asking for European protection, but now, when the negotiations concerning the future of his kingdom were already in progress, he suddenly announced that he wished to rule his own country himself, "as the Rajahs of Pontianak, Kedah, and Acheen do". He agreed that the continuance of friendly relations with European powers was desirable, and promised that he would guarantee the safety of European traders, but he demanded that "all the servants of both the English and Dutch Companies ${ }^{74}$ be removed" from his dominions. ${ }^{75}$

72 "Il ne nous appartient pas à nous, qui ne sommes appelés qu'à mettre le dit traité en exécution, d'en faire". (Commissioners-General to Fendall, September 15th, 1816: Dutch Records 'A', No. 12). There was more than one suggestion from the Dutch side that Fendall's objections were no more than hair-splitting and prevarication.

73 Ibid.

74 Sic. Long after the demise of both the Dutch and English East India Companies the word 'Company' continued to be synonymous with 'Government' in ordinary Malay speech. In Malaya this practice has survived to the present day. (Cf. komperni punya, 'belonging to Government').

75 Sultan of Bandjermasin to Fendall (n.d.). (Dutch Records 'A', No. 12). 
The existence of a large, privately-owned concession at Moloeko gave rise to the third of Fendall's difficulties. Alexander Hare announced that he was going to retain possession of his 1,400 square mile property whether Bandjermasin was handed back to the Dutch or not. Fendall had to take Hare's intentions with regard to Moloeko into account because the Convention of 1814 had laid down that the property rights of individuals electing to remain in transferred territories must be respected by the governments concerned. The Resident of Bandjermasin and others had "embarked their property in the positive or implied faith of government", and Fendall did not feel justified in closing the British establishment down finally until their claims had been investigated and, if necessary, met. $^{76}$

The Lieutenant-Governor sought to gain time by attempting to persuade the Dutch that, despite the terms of the Convention of 1814, their right to Bandjermasin was unfounded. He drew attention to the entries in the public records of Java which showed that Marshal Daendels had "formally and fully withdrawn" from southern Borneo in 1809 , and had resigned all pretensions there; that Bandjermasin had not been included among the territories made over to the British Government by General Janssens in 1811, and had therefore not been acquired by the British by right of conquest; and that the colony was currently held by Great Britain "under a distinct and separate Cession voluntarily made by the Prince of the Country to the British Government alone".77

These assertions were undeniable as statements of historical fact, but the Dutch regarded them as irrelevant. They retorted that Daendels' withdrawal from Bandjermasin was "an act entirely of a military nature", and that the Marshall "had no right to abandon a possession... without the Authority of the European Government". ${ }^{88}$ In making such an admission the Commissioners-General seriously weakened their case. The disobedience of a Dutch Governor-General was scarcely the concern of a representative of the English East India Company, and Fendall was not slow to point this out. "If Marshal Daendels has exceeded his power", he wrote, "he is responsible to his Government for having done so; the act itself has been conclusively executed, and the Sultan of Bandjermasin considered it so when he

76 Minute by the Lieutenant-Governor, August 20th, 1816. (Ibid).

${ }^{77}$ Fendall to the Commissioners-General, July 15th, 1816. ('Register der Handelingen.... van Commissarissen Generaal', 1 Mei tot 30 Augustus 1816).

78 Commissioners-General to Fendall, August 20th, 1816. (Ibid). 
concluded the Treaty with the British Government of Java in the Year $1812^{\prime \prime} .{ }^{9}$

The Commissioners-General were therefore obliged to drop this line of argument, but they continued to insist that Bandjermasin ought to be restored to them, without further prevarication, under the terms of the Convention of 1814. Neither side would give way, and the result was a deadlock. The British dilemma was summarized by the Board of Commissioners when it wrote, with a touch of exasperation: "The retention of [Bandjermasin] as a British Settlement appears equally as impracticable as its transfer to the Dutch". For their part, the Commissioners-General were unwilling to risk future Dutch influence in the area to the hazard of an entirely new approach to the Sultan knowing, as they did, that everything could be much more conveniently arranged by a simple transfer from the British to themselves. Each party to the dispute was therefore compelled to act independently of the other. The British instructed a three-man commission to go to Bandjermasin in order to arrange for the withdrawal of the East India Company's forces, and Fendall advised the Dutch of this intention, "leaving it open to them to proceed in their arrangements with his Highness as they thought proper".80

The three Bandjermasin Commissioners, Thomas Abraham, Robert Stuart, and Lieutenant Cathcart Methven, left Batavia for Borneo on September 30th, 1816. This was some time before the Dutch were ready to send similar representatives, but Fendall explained that "the advanced state of the season" made it necessary for the British Commissioners to proceed "without more delay". ${ }^{81}$ A difficult task awaited Abraham and his colleagues on their arrival. European powers have often found it more harassing to withdraw from colonies than to establish them.

The Commissioners ran into trouble immediately they asked to see the Residency accounts. Alexander Hare was in Java at the time, on recreational leave in Rembang, and he was successfully resisting all Fendall's attempts to make him return to Borneo. ${ }^{82} \mathrm{He}$ had removed

79 Fendall to the Commissioners-General, September 5th, 1816. ('Register der Handelingen.... van Commissarissen Generaal', 1 September tot 31 October 1816).

80 Fendall to the Supreme Government, October 15th, 1816. (Dutch Records 'A', No. 12).

81 Fendall to the Supreme Government, October 14th, 1816. (Ibid.).

82 Charles Assey to Alexander Hare, October 10th, 1816. (Ibid). 
the whole of the general accounts of the settlement to Batavia, and his brother, John, whom he had left behind in charge of affairs, explained to the Commissioners that there was no other copy. ${ }^{83}$

The problem of disposing of the convict and 'free settler' population on Hare's rice and pepper estates caused the Commissioners even greater perplexity. Their instructions allowed them three courses of action: they could hand the convicts over to the Sultan's care, remove them to another penal settlement, such as Penang or Bengal, or return them to Java. The first of these alternatives proved impracticable when the Sultan refused to accept any new subjects, on the ground that he could not feed them; the second would have involved considerable delay and expense; and the third required the prior assent of the Dutch Commissioners-General, since by this time the British no longer had any power to make decisions affecting the internal administration of Java. There was the added complication that most of the convicts had been banished by Javanese courts to serve their time specifically in Bandjermasin, and tedious court proceedings would be required if these sentences were to be changed. ${ }^{84}$ British authority, moreover, no longer extended to Javanese native courts.

The disgraceful story of the colony's public accounts was repeated when the Commissioners began examining Hare's convict registers. They found that no accurate nominal roll of the Javanese in Bandjermasin existed. They were therefore obliged to make their own lists, and even these were sadly deficient. Against many large blocks of names they had to write: "No period specified in the sentences of these persons", or, "No record of the crimes of these Settlers". Some unfortunates were merely given serial numbers, which were bracketed together opposite the entry, "No record of names or crimes". ${ }^{85}$

Anxious to avoid as much delay as possible in closing down the Bandjermasin settlement, the British Commissioners decided to ship convicts and free settlers alike back to Java. Not all the exiles, however, were willing to go. One eye-witness reported that two hundred and fifty of them "absconded into the woods" when the order for their removal was issued, and that "in general it was necessary to surround them with

83 Bandjermasin Commissioners to Fendall, November 28th, 1816. (Ibid).

84 'Minute by General Keir', Proceedings of the Java Board of Commissioners, October 1st, 1816. (Ibid).

85 A copy of these lists was included in a dispatch from Fendall to the Supreme Government of December 26th, 1816. (Ibid). 
troops on the way from the colony to the place of embarkation". ${ }^{86}$ The arrival in Java of those that were successfully collected provoked an immediate outburst from the Dutch, who had already announced their unwillingness to receive them. Yet in the circumstances it is difficult to see what else the British Commissioners could have done. The Sultan had refused to accept responsibility for so boisterous an addition to his population; they could not be left in Hare's charge, since he was not there, nor was his chief assistant, van der Wahl; and injustice would merely have been heaped on injustice if these natives of Java had been transported to Penang or Bengal, places still farther distant from the country from which, in the first place, most of them should never have been removed.

Nevertheless, although the decision to send Hare's labour force home was probably correct, the methods used to carry out that decision gave the Dutch Commissioners-General cause for justifiable complaint. On November 22nd, 1816, for example, a shipload of 61 men, women, and children arrived unannounced off Grisek roads on the north coast of Java. No papers of any kind accompanied them. Their captain's only orders were to land his passengers at Grisek or, failing that, "somewhere else on the Javanese coast". ${ }^{87}$ The same thing happened at Rembang on December 7th; 138 so-called bannelingen (exiles) appeared in the harbour, but the master of their ship had no lists of his charges whatever. Similar unexpected arrivals were reported from other places along the north coast. ${ }^{88}$ Some local Dutch officials refused entry to both convicts and free settlers alike until proper investigations could be made; others allowed them to land. As a result many notorious criminals were released on Javanese society in the guise of 'free settlers' from Bandjermasin, and a number of outbreaks and disturbances were caused by them, particularly at Cheribon. The blame for these occurrences must ultimately be laid at the door of Alexander Hare for failing to distinguish in the records of his administration between genuinely free persons and convicted felons. Fendall subsequently admitted to the Supreme Government of India that the Dutch had "too much ground of complaint in the Classification of the People", and an Anglo-Dutch commission of inquiry, appointed to deal with the unwelcome influx,

86 J. C. Ross to Raffles, January 17th, 1825. (India Office Library MSS Eur. C. 36.)

87 Van der Kemp, 'Het afbreken....', p. 60.

88 P. H. van der Kemp, Het Nederlandsch-Indisch bestuur in 1817, tot het vertrek der Engelschen, pp. 68-79. 
reported that "there are many individuals classed as Free People who cannot be said to have any Right to be landed in their native Country". ${ }^{89}$

Meanwhile, final arrangements were being made for the withdrawal of the East India Company's establishment from Bandjermasin. Once the Sultan was sure that the British were really going, he became extremely affable towards them, and gladly waived any claims he might have made against Hare for ruining his pepper gardens, lest the need for further investigations should delay the Commissioners' departure. He was delighted when Abraham presented him with a quantity of gunpowder "for ceremonial purposes and also for defence against the pirates", and overjoyed when his request was granted for an official deed of transfer restoring him to full sovereignty over his ancestral dominions. The Commissioners were surprised to find, however, that his prevailing mood of generosity extended to the Netherlands Government as well. They reported to Fendall that, in the course of their conversations with him, the Sultan had shown a degree of moderation and good humour for which they had not been prepared, and they had concluded that it was "quite unnecessary to pave the way further for the successful negociation of the Dutch" at Bandjermasin. ${ }^{00}$

On November 9th, 1816, the East India Company's flag at Fort Tatas was hauled down for the last time. A fortnight later the three British Commissioners set out from the capital to Moloeko, where they proposed to wait for a favourable wind to take them back to Batavia. On December 3rd, just eight days after the British officials had left, a Dutch warship dropped anchor in Bandjermasin River with the representative of the new ruling power on board.

The new Dutch Commissioner for Borneo was Mr. Jacob d'Arnaud van Boekholtz. His appointment was notified by the Java Government Gazette on November 23rd, 1816, in the following words: "De Heer $\mathrm{J}$. van Boekholtz, tot commissaris ter overname van het etablissement van Bandjermasin". The use of the expression, "ter overname", in this connection was unfortunate. It means "for the purpose of taking over",

89 The report of this commission is included in Fendall's dispatch to the Supreme Government of December 26th, 1816.

A Netherlands Indian Government decree of May 13th, 1817, finally decided the fate of Hare's settlers. Some were allowed to go free, some were banished anew or given terms of forced labour, and some were sent to work on private estates. (Van der Kemp, 'Het afbreken...., pp. 130-4.)

00 'Minutes of a Conference with the Sultan of Bandjermasin at Martapoera', October 20th, 1816. (Dutch Records 'A', No. 12.) 
and the Gazette announcement indicated to Fendall and his colleagues that the Commissioners-General were persisting in their view that Bandjermasin was no different from the other settlements already surrendered to them under the 1814 Convention, and ought therefore to be handed over on similar terms. The impression thus created may not have been deliberate, but its effect was to embitter still further the strained relations between the two sets of commissioners in Batavia.

Commissioner van Boekholtz, with a small civil establishment and sixty soldiers, made the voyage to Borneo in the colonial navy vessel, Iris. They found everything at Bandjermasin in ruins. The official houses of the Resident and the officer commanding the troops were uninhabitable; the local Bandjar population had occupied the customs house; the barracks were derelict, and the only accommodation that could be found for the soldiers was in the pepper godown. The 'fort' at Tatas turned out to be no more than a delapidated wooden palisade, ten or twelve feet high. Its only occupant was a mandur, or overseer, asleep on the ground; no guns or ammunition were to be seen anywhere; and the Sultan's flag flew overhead. ${ }^{\text {g1 }}$

Van Boekholtz knew that his only hope of success lay in winning over the Sultan to a voluntary acceptance of Dutch sovereignty, since the meagre forces at his disposal would not be sufficient to command obedience should any resistance be offered. The most recent communication from the Sultan, dated some six months before, had given no indication that Dutch rule would be welcome. His Highness had then declared that he wanted "neither English nor Hollanders" in his dominions. ${ }^{92}$ Would his attitude have changed now?

There was no doubt on this score in the minds of the CommissionersGeneral at Batavia. They wrote to the Sultan suggesting that the proposed renewal of former bonds between Bandjermasin and the Government of Java would be "so much the more pleasing to His Highness since, Holland having been raised to the status of a powerful kingdom... His Highness can now rely for ever on complete protection and indissoluble goodwill and friendship". ${ }^{93}$ The CommissionersGeneral took it for granted that the Sultan's apparent unwillingness

91 P. H. van der Kemp, Oost-Indië's herstel in 1816, pp. 411-12, and 'Het afbreken....', pp. 67-8.

82 Sultan of Bandjermasin to the Commissioners-General, May 28th, 1816. (Van der Kemp, Oost-Indië's herstel, p. 399.)

28 Commissioners-General to the Sultan of Bandjermasin, November 9th, 1816. (Ibid., p. 403). 
to acknowledge Dutch sovereignty was the result of British pressure. Complaining to Goldberg, the Chief of the Colonial Department in Holland, they wrote: "We have been told that although possession will not be retained by the English Company, the Sultan will be left as an independent prince; the result has been that the Sultan himself has written ... that he does not desire us". ${ }^{94}$ But with the British out of the way, the Commissioners-General felt, the Sultan would offer no objections.

The British representatives at Bandjermasin had not in fact been guilty of poisoning the Sultan's mind against the new Java Government; on the contrary, they had spoken of it in the highest terms. ${ }^{95}$ But in any case the confidence of the Commissioners-General that Dutch rule would be acceptable to him was fully justified. Van Boekholtz was welcomed with open arms, all his immediate requests were granted, and a definitive contract between the Kingdom of the Netherlands and the Sultanate of Bandjermasin was signed on New Year's Day, 1817, in the presence of the Sultan's court and all his pěngerans.

By this contract, the Sultan ceded to the Dutch Government "in full ownership and sovereignty... the island, town, and fort at Tatas, Kween, all the Dyak provinces, the districts of Mendawai, Sampit, and Kota Waringin with all their dependencies, together with Sintang, Lawai, and Djelai, Bakoempai, Tabanio, and Pagatan, with Poeloe Laoet, Pasir, Koetei, Berouw, and all their dependencies". (Article V). He granted to the Government of Java extensive wood-cutting, gold, and diamond concessions (Article IX), undertook to appoint only persons acceptable to the Dutch administration as his chief ministers (Article XI), and agreed to reject the diplomatic advances of other European powers (Article XIX). In return, the Java Government bound themselves "to stand by His Highness the Sultan and to protect him with force of arms against all native and foreign enemies who threaten to destroy the peace, prerogatives, and safety of His Highness' house, lands, or people". (Article III).$^{96}$

The most striking feature of this contract was the unconditional support it guaranteed to the Sultan of Bandjermasin. By Article XIV, His Highness was allowed to retain "the free exercise of jurisdiction, as

${ }^{94}$ Dispatch of October 9th, 1816. L A, Secret. (Ibid., p. 401.)

o5 'Minutes of a Conference with the Sultan of Bandjermasin....', October 20th, 1816. (Dutch Records 'A', No. 12.)

06 The text of the Contract of 1817 is given by van der Kemp in 'Het afbreken....', pp. 139-45. 
well civil as criminal... over all trespasses and misdemeanours committed by his own subjects within the boundaries of his own Kingtom". ${ }^{97}$ Yet Article III assured him, without any reservation, that the Government would support him against "all native and foreign enemies". It is true that the Dutch administration retained the right to control the succession to the throne and the appointment of the chief court officials (Articles X and XI), but its authority did not extend to the mass of the population; here, the Sultan's traditionally autocratic powers were left unimpaired. The third article of the contract, therefore, if interpreted literally, would have compelled the Dutch to intervene automatically on the Sultan's behalf against any rebellion or disturbance of the peace in Bandjermasin; and yet the fourteenth article denied them the power to investigate the rights and wrongs of particular cases. Almost any offence could be described by the Sultan as endangering the "peace, prerogatives, and safety of his house, lands, or people", and the Dutch administration, lacking the means for detailed investigation, would have difficulty in contradicting him. The success of the system of indirect rule established by the Contract of 1817 was therefore likely to depend very largely on the Sultan of Bandjermasin's willingness to be guided by the Dutch in his domestic affairs; even more important for the future, the terms of this contract made it quite certain that the Netherlands Indian Government would be permanently involved, on one side or the other, in the dynastic struggles of the Sultanate.

Nevertheless, the Commissioners-General could congratulate themselves on having obtained the sovereignty over a vast tract of territory at relatively little cost. The readiness of the Sultan to make such handsome concessions after his recent display of independence is not easily explained. Stapel suggests that his motive was "possibly the fear of Dutch guns, but more probably the realization that European protection was necessary to him". ${ }^{88}$ Kielstra remarks that the Sultan presumably thought Dutch support indispensable because he was not the lawful occupant of the throne in the eyes of his people. ${ }^{9 \theta}$ In any case, as van der Kemp points out, many phrases in the contract would have had no more significance for him "than when, in the rich phraseology of

97 All other peoples in southern Borneo - Europeans, Chinese, 'Moors', Bugis, Macassars, Mandarese, Balinese - "not being subjects of His Highness", were placed under the direct jurisdiction of Dutch courts. (Article XV).

28 F. W. Stapel (ed.), De geschiedenis van Nederlandsch-Indië, Deel v, p. 157.

99 E. B. Kielstra, De Indische archipel, p. 240. 
the East, the whole house and all that is in it are placed at the disposal of the arriving guest". ${ }^{100}$

To both van Boekholtz and the Commissioners-General, however, the immediate problem was not how to fulfil their new obligations to the Sultan of Bandjermasin but how to deal with the tenacious Alexander Hare. The sometime 'White Raja of Moloeko' was by no means reconciled yet to the loss of his Bornean kingdom. In October 1816 he had demanded that the British Board of Commissioners should obtain estates for him in Java as compensation for those he seemed likely to lose in Bandjermasin, but this request had naturally been rejected. He had thereupon paid a brief visit to Borneo in order to instruct his second-in-command, Clunies-Ross, ${ }^{101}$ to oppose Dutch 'aggression' against Moloeko with all possible means, but it was typical of Hare that he did not wait at Bandjermasin to see what the outcome of such resistance might be.

Van Boekholtz was uncertain at first how best to proceed against the Moloeko estates. "It is my opinion", he reported to the Commissioners-General, "that the land was indeed presented to [Hare] not only 'in full ownership', as private lands are held in Java, but with even more extensive rights - as can be seen from the deed of cession which is in Hare's hands in Batavia". ${ }^{102}$ But the Government of Java were in no mood for legal quibbles. They advised van Boekholtz that "no consideration can be given to the view that Mr. Hare, or anyone else, other than the recognized Government, possesses sovereignty or territorial rights [in Bandjermasin], or can possess them", ${ }^{103}$ and ordered him to take over the Moloeko properties immediately.

The Dutch Government's attitude to Hare at this time is well illustrated by a private letter from Elout (the most forceful of the Commissioners-General) to the Colonial Department in Holland. "We have received a pressing request from the Sultan of Bandjermasin", he wrote, "for protection against Mr. Hare, whose endless pretensions our official and private letters have mentioned many times already. The necessary orders have been given for the resumption of his land by the local authorities. Mr. Hare and his representative have tried to lead us up the garden path (ons om den tuin te leiden) : he is a

100 Van der Kemp, 'Het afbreken....', p. 77.

101 John Clunies-Ross (1786-1854), who later achieved fame as the first 'King of the Cocos Islands'. (See Gibson-Hill, op. cit., passim).

102 'Report of Commissioner van Boekholtz', in 'Nederlandsch-Indië in 1817', $T$ vNI, 1861, i, p. 358.

103 Commissioners-General to van Boekholtz, May 31st, 1817. (Ibid., p. 363). 
friend of Mr. Raffles, though held in contempt by all the other members of the former British administration here" ${ }^{104}$ Hare's friendship with Raffles was not likely to endear him to the Dutch CommissionersGeneral.

Clunies-Ross had meanwhile been taking all measures to put the Moloeko area in a state of armed defence. He hoisted the Union Jack, fortified the shore opposite the Dutch fort at Tabanio with three batteries of guns, and sent off a letter to the Government of Java reaffirming his employer's rights and demanding that they be respected. Ross' version of events at Bandjermasin was, not unnaturally, the exact opposite of the account given by the Dutch. For him, the arch-villain was Hare's deputy-resident, van der Wahl, who, in Ross' words, had "oppressed the people, imposed arbitrary duties on trade, and turned the salt monopoly to his own advantage". Ross maintained that van der Wahl was hand in glove with the Sultan's chief minister, and that the two had been sharing the profits of a series of "improper dealings". Hare, on the other hand, had been kept in "complete ignorance of their proceedings until it was too late". ${ }^{105}$

This state of armed defence at Moloeko lasted for some time, while all parties to the dispute cast about in search of additional support for their arguments. The Sultan feigned complete ignorance of the whole affair. When asked about the terms of his original cession of land to Hare, he explained that he had 'lost' his copy of the deed, but that, so far as he could recall, the lease had been a temporary one, granted to Hare only while he retained his post of Resident of Bandjermasin. Hare himself turned to his former protector, Raffles (now LieutenantGovernor of Bencoolen), and offered, through him, to surrender his holdings to the British Crown, "without any stipulation for his own advantage, or remuneration, except what liberality may suggest". ${ }^{108}$ This proposal met with no response. The Supreme Government of India, having just abandoned one settlement at Bandjermasin, was hardly likely to be interested in another, situated in the middle of newly-acquired Dutch territory.

The Sultan's opportune fit of forgetfulness strengthened the Java

104 Elout to Goldberg, May 22nd, 1818. (Quoted in van der Kemp, Het Nederlandsch-Indisch bestuur in 1817 ...., p. 409).

105 J. C. Ross to Raffles, January 17th, 1825. (India Office Library MSS Eur. C. 36).

106 'Memorandum respecting the complaint preferred by Mr. Hare...' (Dutch Records 'A', No. 12). Cf. Gibson-Hill, op. cit., pp. 50-2, where Hare's offer to transfer his Moloeko estates to the Crown is discussed in detail. 
Government's hand and, in May 1818, the Commissioners-General made their final decision regarding the disputed estates. They categorically denied that Hare had any legal title to Moloeko, and declared that his representative, Ross, had forfeited all right to favourable treatment because of his highhanded behaviour. The Dutch officials at Bandjermasin were ordered to take possession of Moloeko, if necessary, by force. $^{107}$

A less obstinate man might well have given up at this stage, but Alexander Hare was both obstinate and optimistic. Even after the Dutch had taken over his lands he refused to admit defeat. He immediately renewed his assault on the Government of Java with fresh demands for compensation, basing his claim on Article VIII of the 1814 Convention, which had permitted six years' grace for the disposal of property in transferred territories. When this appeal failed, he turned finally to the Supreme Government of India in the forlorn hope that it might yet uphold his legal rights under the Sultan's original land concession. But unfortunately for Hare, his reputation arrived in Calcutta before his plea. John Fendall was now back in Bengal, and when Governor-General Lord Moira asked for his advice, the opinions Fendall expressed of the former Resident of Bandjermasin were so damning that Moira wrote to the Dutch Commissioners-General disclaiming all intention of interfering in the matter. "Your Excellencies", said the Governor-General, "do not require to be informed of the sentiments entertained by us of the conduct of Mr. Hare and the proceedings connected with the Establishment formed by him at Bandjermasin, and you will not suppose that we can have any desire to screen a person whom we regard as a delinquent". ${ }^{108}$

On October 11th, 1819, the Dutch Minister of the Colonies, A. R. Falck, sent the following message to King William of the Netherlands: "With regard to the lands which the sometime Resident Hare contends were presented to him by the Sultan of Bandjermasin, it appears anew how unfounded that claim is, and how necessary the resumption of these lands by the Dutch Government has been. On the part of the agent of the said Hare, there has been no further opposition, other than the signing of a protest of no significance". ${ }^{109}$

Side by side with these observations of the Dutch Colonial Minister may be placed the following quotation from an India Board minute of ${ }_{107}$ Besluit of May 22nd, 1818. (Van der Kemp, 'Het afbreken....', pp. 156-8), 108 Governor-General in Council to the Commissioners-General, November 7th, 1818. (Dutch Records 'A', No. 28).

109 Quoted by van der Kemp, 'Het afbreken...., p. 92. 
July 4th, written in response to a memorial presented by Alexander Hare to Lord Castlereagh. "Mr. Hare", it declared, "has been forcibly dispossessed; the Dutch may say that the Treaty they have now with the Sultan forbids the alienation of land to a foreign European, but can it be retroactive? The equity of such a proceeding can hardly be maintained in bar of Hare's right to compensation. This property was formally conferred on Hare when the Sultan was independent of the Dutch". ${ }^{110}$

Hare was expelled from the Netherlands Indies early in 1820, and went to live at the Cape of Good Hope. From there he continued to plead his case through his brother in London and by means of memorials to the British Treasury, but without success. In 1827 he settled in the Cocos Islands and, after disputing possession of them for many years with his former employee, John Clunies-Ross, was finally ejected in 1831. From Cocos he moved to Bencoolen and probably ended his days there or while on a journey into the Sumatran interior a year or so later. ${ }^{111}$

Soon after Netherlands sovereignty had been proclaimed over Bandjermasin in January 1817, the West Coast states of Pontianak and Sambas also requested the return of the Dutch. Early in that year the Sultan of Sambas wrote to Resident Parve of Samarang explaining that, since his attempts to obtain the assistance of the 'lord general Raffles' had come to nothing, he now desired the support of the present Government of Java, so that his lands might be better ruled. ${ }^{112}$ On another occasion, however, he wrote to Parvé to ask for "a copperbottomed vessel with two or three masts, carrying 18 guns, each of 3 or 4 asta, 6 or 7 pikuls of gunpowder, and 96 good 'Company' muskets". ${ }^{113}$ The obvious suitability of such a vessel for purposes of piracy suggests that the Sultan of Sambas was hoping that Dutch protection would not necessarily mean the end of his distinguished career as a pirate chief. Nevertheless, the Government of Java advised him that his request for a Dutch Resident would be granted, and that a contract of friendship and protection would soon be offered him.

The Sultan of Pontianak was not slow to follow his traditional

110 Dutch Records 'A', No. 13.

111 Gibson-Hill, op. cit., p. 96.

112 Sultan of Sambas to Resident H. A. Parvé, March 4th, 1817. (P. H. van der Kemp, 'De vestiging van het Nederlandsch gezag op Borneo's Westerafdeeling in 1818-1819. Naar onuitgegeven stukken', BTLV, 1920, p. 119).

113 Ibid., p. 120 . One asta equals about $1 \frac{1}{2}$ feet. 
rival's lead. He told the Commissioners-General that he "gave thanks to God that the Dutch, his sometime brotherly friends, had again taken possession of the island of Java", and expressed the hope that between his country and the Dutch Government there would once again be the same amicable relations as had existed in the time of his father. ${ }^{114}$

On June 9th, 1818, the Commissioners-General decided to take advantage of the friendly attitude of the two Sultans by sending an expedition to western Borneo. Commissioner van Boekholtz had by this time returned to Java from Bandjermasin and he was placed in command of the new expedition. The Commissioners-General told him that his main duties would be to 'show the flag' on the West Coast and in nearby areas, to renew former links with the coastal kingdoms, and also to suppress piracy, since it was clear that no new settlement had any chance of success until the pirate scourge had been removed. He was to negotiate contracts with the local princes where possible, and arrange for the cession to the Dutch Government of a proportion of the customs revenues in each state. ${ }^{115}$

Van Boekholtz, supported by a force of 600 soldiers under the command of Major Muntinghe, reached Pontianak on July 18th. He was amicably received by the Sultan and, on August 9th, the Dutch flag was broken over the capital. Almost immediately the Commissioner received an opportunity of demonstrating the usefulness of a Dutch alliance. The province of Tajan happened to be in revolt against Pontianak at the time, and the Sultan asked for Dutch assistance in pacifying it. Major Muntinghe, with a company of Ambonese soldiers, put himself at the head of the Sultan's forces, and within a very short time order was restored in Tajan. ${ }^{116}$

Leaving the civil administration at Pontianak in the hands of Resident Hartmann, Muntinghe and van Boekholtz proceeded up the coast to Sambas, reaching the river-mouth on September 2nd. As they entered

114 Sultan of Pontianak to the Commissioners-General, October 7th, 1817. ('Nederlandsch-Indië in 1817', TvNI, 1861, i, pp. 365-6).

The reigning Sultan of Pontianak's father was the founder of the kingdom, Abdu'r-Rahman, whom the Dutch East India Company had recognized in 1778.

115 'Instructions to Commissioner J. van Boekholtz, June 19th, 1818'. (Van der Kemp, 'De vestiging ...', p. 124. Veth, op. cit., Deel ii, p. 4).

110 Some doubt exists about the justice of the Sultan's cause in this campaign. George Müller and Commissioners Roesler and Tobias all claimed later that Muntinghe fought on the wrong side and that, as a result, Dutch prestige with the princes of the Coast was seriously weakened. (See Veth, op. cit., Deel ii, p. 10). 
the river, they met a fleet of war-prahus commanded by the Sultan of Sambas in person. His Highness had apparently not yet received news of the arrival of the Dutch in western Borneo, and was much disconcerted at encountering them now, for he was just setting out on a piratical raid against his hereditary enemy, Pontianak. He quickly cancelled these arrangements, however, and warmly welcomed the representatives of the Netherlands Indian Government to his capital. There, formalities were soon concluded; the Dutch flag was raised on September 6th; and on the 23rd, George Müller was installed as ActingResident.

The recognition of Dutch sovereignty by the Sultans of Bandjermasin, Pontianak, and Sambas brings the first stage in the development of Dutch power in nineteenth-century Borneo to a close. A promising start had been made, but as yet scarcely the outlines were clear of the many difficult tasks that lay ahead. No one could tell how long it would be before the Government of Java could expect any return on these, their first small investments in the vast, unexplored island of Borneo. Piracy had to be suppressed, trade had to be stimulated, revenues collected. There were innumerable treaties to be made with the petty kingdoms around the coasts, head-hunting Dyak tribes to be pacified and civilized, powerful and independent Chinese mining communities to be brought into submission to Government.

The accomplishment of any one of these tasks would need years of patient, hard work, free, if possible, from interference by other European powers. But already the unexpectedly swift restoration of Dutch influence to Borneo and other islands of the Archipelago was beginning to cause alarm in Great Britain and in India. For more than twenty years the English East India Company and private British merchants had enjoyed almost exclusive trading privileges in many areas towards which the power of the Netherlands now seemed to be moving closer every day. The merchants of Penang, in particular, feared that the old Dutch monopoly system would be reintroduced, while the Directors in London and the Supreme Government of India saw in Dutch encroachments towards the Straits of Malacca a dangerous threat to the East India Company's trade with China. The result of these various British apprehensions was a sudden revival of Anglo-Dutch competition in the Far East. The diplomatic 'honeymoon' following the settlement of 1814 was over. 


\section{CHAPTER III}

\section{THE TREATY OF 1824}

During the British occupation of Java the absence of Dutch competition had enabled the merchants of Penang to develop an extensive commercial intercourse with the Malay Peninsula and the islands of the Eastern Archipelago. Consequently, when the Netherlands Indian Government began negotiations for the return of the settlement of Malacca - to which they were entitled under the Convention of 1814, but which lay in the very centre of an area the British had come to regard as peculiarly their own - the merchants of Penang became thoroughly alarmed. They feared that the restoration of Dutch influence in Malacca would ruin the valuable trade they had built up with Perak, Selangor, Riouw, Lingga, the West Coast of Borneo, and other places. In June 1818, therefore, they requested Colonel Bannerman, the Governor of Penang, to make such treaties "as may effectively secure the freedom of Commerce with these countries... at least on the stipulation of being allowed to trade on similar favourable terms as may be granted to any other People or Nation". 117

Bannerman accepted this suggestion, and ordered Major John Farquhar, the Resident of Malacca, to proceed immediately to Riouw. Lingga, Pontianak, and Siak in order to secure a "free and unrestricted trade... unfettered by the monopoly" which, he feared, "it would be the first object of the Dutch Government to establish". ${ }^{118}$ Similar orders were issued to W. S. Cracroft with respect to Perak and Selangor. ${ }^{110}$ Farquhar chose Pontianak as his first port of call, and on July 21st, 1818, set out from Malacca for the West Coast of Borneo.

$\mathrm{He}$ arrived there on August 7th, just three weeks after the expedition commanded by Commissioner van Boekholtz dropped anchor in Pon-

117 'Letter of 13 merchants of Penang', June 8th, 1818. (Fac. Rec., Straits Settlements, No. 66).

118 General Letter of the Government of Prince of Wales Island, October 17th, 1818. (Fac. Rec., Straits Settlements, No. 182).

119 Sec. to Govt., Prince of Wales Island, to Sec. to Govt., Fort William, June 26th, 1818. (C. D. Cowan, 'Early Penang and the rise of Singapore, 1805-32', JRASMB, March 1950, p. 76). 
tianak River. He was therefore obliged to sail away again almost at once with his mission unfulfilled, and with a volley of Dutch protests ringing in his ears. $\mathrm{He}$ later succesfully negotiated commercial treaties with Riouw, Lingga, and Siak, ${ }^{\mathbf{1 2 0}}$ but none of these was destined to have any permanent value.

When the report of Farquhar's rebuff at Pontianak reached Bengal, Governor-General Lord Moira (now Marquis Hastings) was not disposed to make any formal protest to the Dutch Government. "However much it may be regretted", he wrote, "that the Dutch should have pre-occupied the ground at Pontianak, and thus destroyed the independence of a Port of considerable importance to our Commerce, I conceive that the question is not of sufficient importance to authorize our entering into any discussion with the Dutch on the subject". ${ }^{121}$ Nevertheless, the Governor-General had no intention of forgetting the Pontianak incident entirely. He added it to the growing list of provocative actions which gave clear proof, in his opinion, of the "boundless pretensions of the Netherlands Government" and of the consequent threat to the East India Company's political and commercial position in the Eastern Seas.

In 1814, it will be recalled, it had largely been as a result of opposition from Lord Hastings that the ambitious plans for Borneo advocated by Stamford Raffles had come to nothing. Since then, however, a marked change had taken place in the Governor-General's attitude to the whole problem of Anglo-Dutch relationships in the East. By 1818, Hastings was no longer so confident as he had been four years before about the continued security of British trade beyond the Straits of Malacca, and in this revision of view Raffles himself had played an important part.

Soon after taking up his duties as Lieutenant-Governor of Bencoolen in March 1818, Raffles began bombarding the Secret Committee of the East India Company in London with a series of proposals designed to protect British interests against the rising tide of Dutch expansion. His main suggestion was that a clear line should be drawn between possessions which the Dutch were legally entitled to resume under the terms of the Convention of 1814 and those which were (or should be, in his opinion) independent of Dutch authority. In the latter category he

120 Sec. to Govt., Prince of Wales Island, to Sec. to Govt., Fort William, September 19th, 1818. (Ibid., p. 80).

121 Minute by the Marquis of Hastings, October 25th, 1818. (Dutch Records 'A', No. 28A). 
placed Pontianak, Sambas, Brunei, Koetei, and Pasir - the five most important native states on the West and East Coasts of Borneo. In addition, he demanded the establishment of a chain of British stations throughout the Archipelago, so placed strategically that they would effectively hinder the extension of Dutch power beyond his proposed demarcation line. ${ }^{122}$

Even this would not be the most suitable solution to the problem. The experience of the past, Raffles argued, was that English and Dutch settlements placed side by side on the same island always led to trouble. Ideally, therefore, the integrity of the larger islands should be preserved; Java, for example, should remain Dutch, Sumatra exclusively English. "With regard to Borneo", Raffles declared, "the Dutch have not a shadow of a claim... The great Island of Borneo is thus very nearly at the disposal of any European Power that may have the inclination to command its resources... I would suggest either that the Dutch should be compelled to withdraw from Borneo altogether, or that at least the equator should form the boundary of their Settlements. As, however, the Dutch have no claim whatever to Borneo, I would hope the former arrangement would be preferred". ${ }^{123}$

Although these suggestions were made direct to the Secret Committee, they were automatically referred to Lord Hastings for his comments. Hastings did not agree with the more ambitious of Raffles' plans, but there is no doubt that their effect, added to his own observations of the scene and the Penang Government's repeated warnings that trade would be ruined if Malacca were returned to the Dutch, was to convince the British Governor-General that a halt must soon be called to Dutch imperialism. He set out his reasons for this decision in a dispatch to the Company in London usually known as the 'Minute of October 25th, 1818'.

The importance of this well-known document in the history of Singapore has always been recognized, but it is no less valuable to the understanding of British policy in Borneo, since it clearly illustrates the part played by events on that island in the alteration of Lord Hastings' attitude to the Dutch. After a brief introduction, the body of the minute continues as follows:

It may be proper to premise the principal circumstances on

122 Raffles to the Secret Committee, April 14th, 1818. (Dutch Records 'A' No. 29).

123 The same to the same, July 3rd, 1818. (Ibid.). 
which my suspicion of the Dutch is founded. The following are the most prominent, exclusive of the distinct tone and character of their discussions in the negotiations connected with the restitution of Java.

1st. Their positive refusal to enter into any pledge to maintain Treaties concluded by the British Government with Foreign Powers - though eminently beneficial to themselves.

2nd. Their immediate occupation of Bandjermasin on the professed ground of their former Treaty, though this had been formally annulled by Marshal Daendels.

3rd. Their recent proceedings at Palembang. ${ }^{124}$

4th. Their forcible occupation of Pontianak to which they had not the shadow of a pretention.

5th. The jealousy and reserve, to use the mildest terms, that have marked all their communications with the British Government.

6th. The collection of Establishments, Naval and Military, at Java, far more extensive than the occupation and defence of their existing possessions can require.

Of these six points, the second and fourth referred directly to Borneo, while the first and fifth derived in large part from the heated controversy over Bandjermasin.

After quoting the suggestions for checking Dutch expansion forwarded at various times by Raffles and Bannerman, Hastings went on to state his own recommendations. British influence, he felt, should be predominant in Atjeh, for it would be very serious for India if the northern tip of Sumatra were to fall into Dutch, French, or American ${ }^{125}$ hands. Malacca should be retained, since if the Dutch made it a free port there would be a danger of its destroying the trade of Penang. Finally, the best all-round solution for both countries, in Hastings' opinion, would be for Britain to command the Straits of Malacca and Holland the Straits of Sunda. ${ }^{128}$

124 A reference to the assumption of sovereignty by the Dutch (much to Raffles' disgust) over Palembang and other parts of eastern Sumatra in 1818. (See E. B. Kielstra, 'De ondergang van het Palembangsche Rijk', in Indisch Nederland, pp. 197-241).

125 During the period immediately following the Anglo-American War of 1812, the establishment of an American trading station at Atjeh or at some adjacent point was thought by the British to be a definite possibility.

126 See Dutch Records 'A', No. $28 \mathrm{~A}$, for the full text of this minute. It also appears in précis form in No. 13 of the same series. 
With the Governor-General thinking along these lines, it is not surprising that when Raffles visited Calcutta in October 1818 to present his case in person, his proposals were more sympathetically received than they had been for years. "I have just returned from spending a week with Lord Hastings", he wrote on November 15th, "and am in high favour". ${ }^{127}$ The outstanding result of their meeting was the permission Raffles received from the Governor-General to found a British settlement at some point in the Straits of Malacca not already under Dutch sovereignty. Early in December Raffles sailed from Calcutta on the mission which led two months later to the founding of Singapore.

The argument which raged back and forth between the Dutch and British Governments over the possession of Singapore has no direct connection with the development of policy in Borneo, and consequently none with the present study. But during the course of the main diplomatic battle many general questions were discussed by the two Governments and solutions to them eventually hammered out. For the British the matter of trading rights in the Indian Archipelago was of the highest importance, and it was not only Dutch competition that they had to fear. Europe's long pre-occupation with the Napoleonic Wars had left the Far East wide open to American enterprise, and ships from New England had been visiting China and the Indian Archipelago in ever-increasing numbers. It was estimated in 1819 that American trade with China alone was currently employing 16,000 tons of shipping a year, compared with a British total of 20,000 tons. ${ }^{128}$ There was also a danger that the French, now that Mauritius had been taken from them at the peace treaty, would be looking for new harbours in the Southern Indian Ocean and perhaps beyond it; and Raffles drew attention to a possible threat from Russia, whose seizure of Japan and the Sandwich Islands was thought to be only a matter of time. ${ }^{129}$

These varied pressures were very much in the mind of the Foreign Secretary, Lord Castlereagh, when in August 1819 he instructed the British Ambassador in The Hague to take a stronger line over Dutch claims in the Archipelago. "There are two principles", he wrote, "from which the British Government can under no circumstances be expected to depart: the one is, they cannot acquiesce in a practical exclusion, or in a mere permissive toleration, of British commerce throughout the

127 Quoted in Hugh E. Egerton, Sir Stamford Raffles, p. 171.

128 Assey, op. cit., p. 23.

120 Raffles to the Supreme Government, January 8th, 1819. (Dutch Records 'A'. No. 28A). 
immense extent of the Eastern Archipelago; nor can they consent so far to expose the direct commerce of this country with China to all the obvious dangers and disadvantages which would result, especially in time of war, from all the military and naval keys of the Straits of Malacca being exclusively in the hands of the Netherlands Government". 130

The Dutch were unable to accept either of these principles; both seemed to threaten the very structure of their colonial system. They knew that British merchants had a considerable hold on trade in the Archipelago already; therefore, they argued, the granting to the British of equal trading privileges, however admirable in theory, would have serious results for the Netherlands in practice, since if all the harbours in the Indian Islands were declared free Britain, with her much greater industrial resources, would soon be able to engross all the trade.

The conflict of national interests here involved was so fundamental that there was no chance of a lasting settlement being achieved by the British and Dutch representatives in the East. In any case, such hostility had grown up between the Governments of India and Tava by 1819 that a common meeting-ground could scarcely have been found. On the one hand, the Dutch distrusted the British practice of acting first and asking permission afterwards in the hope that the home, authorities could be persuaded to recognize the fait accompli; on the other, the British believed that local protests would have no effect until the colonial authorities in the Netherlands had agreed to abandon the policy of expansion. It was only on one point, therefore, that both sides were in complete accord. Lord Hastings echoed the sentiments of the Government of Java as well as his own when he wrote in October 1818: "It is in Europe that the only effectual remedy can be applied". ${ }^{131}$

Towards the end of 1818 Baron Fagel, the Netherlands Ambassador in London, suggested to the British Government that a permanent settlement of Indian affairs was long overdue. ${ }^{132}$ Lord Castlereagh agreed, and discussions between the two Governments would probably

130 Castlereagh to Clancarty, August 13th, 1819, Secret. (Dutch Records 'A', No. 13. Also reproduced in H. T. Colenbrander, Gedenkstukken der algemeene geschiedenis van Nederland van 1795 tot 1840, VIII, i, p. 131).

131 Minute of October 25th, 1818.

132 C. M. Smulders, Geschiedenis en verklaring van het tractant van 17 Maart 1824 ...., p. 37. 
have begun in the new year had Mr. A. R. Falck, the Dutch Colonial Minister, been available to attend them. But he was absent in Vienna at the time, attending a conference on the future of the little German states, and it was decided that C. Th. Elout, the former CommissionerGeneral, should represent Holland at the projected talks. ${ }^{138}$

The selection of Elout was discussed by Falck with the British Ambassador at The Hague, Lord Clancarty. In his report on this conversation to the Foreign Office, Clancarty wrote: "M. de Falck ... seemed to feel the propriety of not mixing more of Indian knowledge than was absolutely necessary in the projected negociation, professing himself to deprecate the larger and more essential interests of the two countries being in any wise influenced by local considerations; [the Dutch] will probably, therefore, have one Indian only [Elout] to join Fagel in the negociation". ${ }^{134}$ The almost casual attitude to Indian affairs shown by Falck on this occasion contrasts strongly with the careful preparations made by George Canning who, with Lord Castlereagh, was appointed to represent Great Britain at the talks. Canning arranged for the East India Company to appoint a special 'Secret Select Committee', whose duty it would be to keep him constantly advised on Eastern affairs while the conversations were in progress. ${ }^{135}$

The death of George III and the cabinet crisis over George IV's attempt to divorce Queen Caroline obliged the British Government to ask for a postponement, however, and it was not until half-way through 1820 that the long-awaited discussions began. Elout arrived in London in mid-July and, having joined forces with Ambassador Fagel, met Canning for the first formal session on July 18th. ${ }^{136}$ Two days later it was decided that the British should prepare a 'draft project', setting out the main points they wished to raise during the discussions.

Canning presented a long list of British proposals on July 22nd. One of these announced the East India Company's willingness to recognize treaties made by Holland since 1817 with the Bornean states of Bandjermasin, Pontianak, Sambas, and Mampawa, "such treaties having

133 P. H. van der Kemp, 'De geschiedenis van het Londensch tractaat van 17 Maart 1824', BTLV, 1904, pp. 46-7.

134 Clancarty to Castlereagh, August 20th, 1819. (Ibid.).

135 Dutch Records 'A', No. 30. Cf. Cambridge History of the British Empire, Vol. ii, p. 601.

13 Both Castlereagh and Canning were named as British plenipotentiaries, but Castlereagh was present only once and on an occasion when nothing constructive was achieved. 
been communicated to the British Government and being found not to contain any article excluding British trade". ${ }^{137}$

The vexed question of Dutch territorial claims in the island of Borneo as a whole was also touched upon. This matter had first been raised as a result of Major Farquhar's abortive West Coast venture in August 1817. On his return from this expedition, Farquhar had told Lord Hastings that the Dutch Commissioner, van Boekholtz, had sternly warned him "not to enter into any negociations with any of the Chiefs of Borneo, as the whole of that immense territory had come under the Dutch supremacy". ${ }^{138}$ A sharp correspondence had ensued between Hastings and Governor-General van der Capellen on the subject, ${ }^{139}$ but now in London, Elout made it clear that his Government "distinctly disavowed" any arrogation of supremacy over Borneo - a statement which officials in East India House noted, with marked prescience, might be valuable "at all events as an admission of principle". ${ }^{140}$

In addition to these two partial clarifications of policy in Borneo, the London talks of 1820 settled a few points of a more general nature. Canning, with Raffles' past exploits in mind, gave an assurance that 'free-lance' actions by British agents in the Archipelago would be disowned; the Dutch representatives agreed that all European ships should be given access to the Indian Islands (except the Moluccas); and both sides promised to exchange information on their future treaties with native princes. ${ }^{141}$ But most of the major issues which the London conference had really been called to settle - such as the debts still outstanding after the transfer of colonies in 1816, the suggested 'demarcation line', and, above all, the question of Singapore - were left in the air. It was consequently suggested by Canning that, since there was obviously insufficient agreement for a formal treaty, the best plan would be to record what had been achieved by an exchange of notes. This

137 'Observations upon the State of the Negociation between the British and Netherland Governments...., India Board, March 1822. (Dutch Records 'A', No. 30). See also Smulders, op. cit., p. 158 and van der Kemp, 'Londensch tractaat', p. 82.

138 Governor-General in Council to the Secret Committee, July 17th, 1819. (Dutch Records 'A', No. 13).

189 Hastings to van der Capellen, June 26th, 1819. Van der Capellen to Hastings, December 16th, 1819. (Ibid.).

140 India House minute, included in 'Misc. Letters and Documents 1818-1824', (Ibid.).

141 Aide mémoire of August 4th, 1820. (Quoted by van der Kemp, 'Londensch tractaat', p. 88). 
was done, and the 1820 talks were allowed to die slowly away. Nevertheless, both Governments were still genuinely anxious for a settlement, and officially the negotations were merely adjourned, face being saved on the British side by the excuse that more information was needed from the Indies. Once this had been obtained, it was hoped that a final binding treaty could be made. ${ }^{142}$

Meanwhile, the development of a critical situation in Europe had obliged the British Foreign Office to measure the value of Dutch friendship in other than purely Far Eastern terms. The urgent need to strengthen the new Kingdom of the Netherlands had been one of the chief reasons why the Dutch colonies were restored in 1814. Since then, Great Britain had felt an increasing necessity to maintain good relations with the Dutch Government. The United Kingdom had been drawing steadily away from her partners in the victorious wartime coalition Russia, Austria, and Prussia - and the fear of France and of a revival of Jacobinism was still strong. As a result, a powerful Kingdom of the Netherlands had become vital to Britain as a bulwark against a possible French irruption into the North European plain. ${ }^{143}$ It was only by cultivating the smaller friendly powers, like Holland, that the traditional British policy of never allowing the Continent to be dominated by one nation could be continued. In the early 1820 's, just at the time when Stamford Raffles' occupation of Singapore had thrown Anglo-Dutch relations in the Far East into a turmoil, it was particularly important from the British point of view that nothing should be allowed to cause friction between the two countries at home. A peaceful settlement of the problems of the Eastern Archipelago had therefore become a matter not merely of local, but of European, urgency.

After an adjournment of three and a half years, the Anglo-Dutch talks on Far Eastern problems were resumed at Gloucester Lodge in London on December 15th, 1823. Their general object remained the same - to arrive at a definitive and lasting treaty between the two powers. Baron Fagel was nominated as before to represent the Netherlands, and George Canning, now Foreign Secretary, appeared again on the British side. The two new faces at the conference table were those of A. R. Falck, who could be spared to make the journey this time. and Charles Wynn, the British President of the 'Board of Commis-

142 Dutch Records 'A', Nos. 13 and 30.

143 Cf. Sir Charles Webster, The Foreign Policy of Castlereagh, 1815-1822, p. 163 
sioners for the Affairs of India'. ${ }^{144}$ Neither the Dutch nor the British minutes of these talks have survived; probably none were kept. ${ }^{145}$ Sufficient evidence is available, however, for the main course of the discussions to be accurately determined.

Arguments over financial matters occupied a great deal of the time, consuming several whole sessions. Since 1816 a number of British accounts against the Netherlands Indian Government had been awaiting payment; these were part of the aftermath of the 1814 Convention, and had provided a minor, but persistent, source of discord for years. Now at last the matter was finally cleared up, the Dutch representatives agreeing to pay $£ 100,000$ sterling in full settlement of all outstanding claims.

Rather less time seems to have been devoted to the relatively much more important question of Singapore. By the end of 1823, Raffles' controversial little colony had been in existence for five prosperous years, and it was becoming increasingly clear to the Dutch Government that the East India Company would not lightly relinquish it. During the talks at Gloucester Lodge, therefore, Fagel and Falck used Singapore more as a bargaining point than as a battle-cry; they hoped that by giving way to the British here, they would stand a better chance of extracting concessions elsewhere. In consequence, Canning and Wynn found to their surprise that although they had to struggle hard on the compensation question, they were not pressed as closely as they expected about the British title to Singapore. This prompted Canning to remark in a note to the Secretary of the Board of Control, "We have a good claim of money and a doubtful one (to say the least) of territory. [Yet] we carry our doubtful case and are foiled upon our clear one... Our situation is one altogether whimsical". ${ }^{146}$

As the talks proceeded, however, the British and Dutch plenipotentiaries found much ground in common. Gradually they were able to resolve the countless difficulties and misunderstandings which had plagued their two countries in the East for so long and, by the end of January 1824, substantial agreement on all major issues had been reached. Another two months were to go by before the necessary consultations with the colonial departments in London and The Hague

144 Dutch Records 'A', No. 30.

145 See van der Kemp, 'Londensch tractaat', p. 185, on the absence of Dutch minutes. Summaries of the proceedings at each session are to be found in Dutch Records 'A', Nos. 30 and 31.

146 Canning to Courtenay, January 17th. 1824. (Dutch Records 'A', No. 31). 
had been completed, but on March 24th, 1824, the "Treaty between His Britannick Majesty and the King of the Netherlands respecting Territory and Commerce in the East Indies" was signed at last.

The fate of Singapore was decided by the Twelfth Article of this Treaty. In its final form, this Article ran as follows:

His Netherland Majesty withdraws the objections which have been made to the occupation of the Island of Singapore by the Subjects of His Britannick Majesty.

His Britannick Majesty, however, engages, that no British Establishment shall be made on the Carimon Isles, or on the Islands of Battam, Bintang, Lingin, or on any of the other Islands South of the Straits of Singapore, nor any Treaty concluded by British Authority with the Chiefs of those Islands. ${ }^{147}$

So far as Singapore itself was concerned, the article was plain enough, but the vital question for the future of Borneo was, What, precisely, was the meaning of the expression, "or any of the other Islands South of the Straits of Singapore"?

Strictly speaking, the only parts of the East Indies that did not lie 'south of Singapore' were north-western Sumatra - from which, by a separate article of the Treaty, the British agreed to withdraw slightly less than half of Borneo, the northern tips of Celebes and Halmahera, and the small island of Morotai. Was it then the intention of Article Twelve of the Treaty of 1824 that Britain should henceforth be prohibited from colonizing or treaty-making throughout the whole length and breadth of the Indian Archipelago?

This was certainly the view taken by many contemporary observers. T. J. Newbold, for example, an early historian of the British settlements in Malaya, complained in 1839 that "the comprehensive little sentence 'Islands south of the Straits of Singapore' politically shuts us out from the richest part of Borneo, the tin mines of Banca, the islands of Billiton, Madura, Bali, Lombok, Sumbawah, Flores, and nearly the whole of the Celebes, in addition to the loss of Achin and

147 The full text of the Treaty of 1824 is given in Sir William G. Maxwell and W. S. Gibson, Treaties and Engagements affecting the Malay States and Bormeo, pp. 8-12. 
the rest of Sumatra". ${ }^{148}$ A similar view was expressed six years later by a Dutch Minister of the Colonies, J. C. Baud. As a result of the Treaty of 1824, he wrote, "England may not establish herself nor conclude treaties with the rulers of any island lying to the south of $1^{\circ} 30^{\prime}$ N., for that is the latitude of Singapore Straits"..$^{48}$ Many Dutch writers of the present day have taken the same line. H. T. Colenbrander, for example, declares: "After the Treaty of 1824 the only part of the Indies in which it was possible for England to establish her political authority was North Borneo", ${ }^{150}$ while B. H. M. Vlekke, describing the provisions of the Treaty in his book, Nusantara, ${ }^{151}$ writes: "Moreover, the British promised not to interfere further with Sumatra or any of the other islands of the archipelago".

On the other hand, it has been suggested by some that the phrase, "Islands South of the Straits of Singapore", is to be understood in a more restricted sense, on the ground that its authors intended it to apply only to the immediate area of the Straits themselves. Those who hold this view point out that the purpose of Article Twelve was to set a limit to the amount of territory comprised by the term, 'Singapore', not to carve up the whole Archipelago between Dutch and British. Which of these interpretations is correct? The answer must be sought in the records of the conference between the men who drew up the Treaty, Canning, Fagel, and Falck.

Towards the end of the London talks of 1823-4 Falck produced a 'draft project' setting out the chief Dutch proposals. Appended to the main body of this draft were two special articles, the second of which contained the following far-reaching recommendation: "The contracting parties shall bear in mind that their respective possessions in the East Indies are divided by a 'line of demarcation', beginning at the entrance of the Straits of Malacca at the parallel of Kedah (the 6th degree North Latitude) and terminating at the end of Singapore Straits, thus leaving

148 T. J. Newbold, Political and Statistical Accormt of the British Settlements in the Straits of Malacca, Vol. i, p. 17. The publicist, John Anderson, copied this passage direct from Newbold, and reproduced it the following year in his work, Acheen.... with Incidental Notices of the Traae in the Eastern Seas and the Aggressions of the Dutch, at p. 3.

149 J. C. Baud to the King, August 30th, 1845, No. 302, Very Secret. (Buit. Zaken, No. 3133).

150 Koloniale geschiedenis, Deel i, p. 329.

161 At p. 264. (My italics). 
this island to the North, and the Carimon, Battam, Bintang, and Riouw islands to the South..." 152

The idea of an imaginary line delimiting the areas of British and Dutch aspiration in the Eastern Archipelago had first been put forward by Stamford Raffles. ${ }^{153}$ It was taken up again at the 1820 discussions, this time by the Dutch. Elout's plan had then been for the whole of Borneo to be placed on the Dutch side of the line, including the island of Balambangan and other parts of northern Borneo which had once belonged to the English East India Company. ${ }^{154}$ But this scheme was not pursued, mainly, it seems, because of Dutch fears that the British might not be willing to withdraw completely from Sumatra if they were too formally and insistently excluded from Borneo.

Now at the Gloucester Lodge discussions, however, a somewhat similar proposal was being advanced, but with this significant difference: the new line of demarcation was to end just east of Singapore; it was not intended to be prolonged as far as Borneo. Exactly what was in Minister Falck's mind when he made this new suggestion is not clear. A member of his staff, Hora Siccama, described many years later how Falck came home in great jubilation one day after a session with Canning and Wynn, and announced that "a great principle had been agreed": the Netherlands were to cede to England all their possessions on the mainland of India, and in return "Great Britain would withdraw from the islands". Then, by way of explanation, Falck drew a line on the map, which ran "from the northern tip of Sumatra, through the Straits of Malacca, around Johore, and after that, North". Asked if this meant that Borneo fell below the line, Falck replied, "Yes, but we may not get it in the Treaty; the English ministers will have enough trouble in Parliament as it is. The question will doubtless come up later - then it will be time enough to assert our rights. For the present it is sufficient for us that the British desire no further expansion of the possessions of the East India Company, and that they hope to provide once and for all against collisions between our two Governments". 155

152 Smulders, op. cit., pp. 54-5.

153 See pp. 53-4 above.

154 Council of Ministers to the King, November 5th, 1845. (Buit. Zaken, No. 3133).

155 O. W. Hora Siccama to Jhr. Mr. P. J. Elout van Soeterwoude, October 26th, 1858. (P. J. Elout van Soeterwoude, Bijdragen tot de geschiedenis der onderhandelingen met Engeland, betreffende de overzeesche bezittingen 1820-1824, pp. 311-12). 
Believing that he had secured a 'gentleman's agreement' on Borneo with his British colleagues, Falck became the more anxious that the proposed division of the Archipelago should not cause unnecessary trouble. On January 9th, when asked by Canning to be more precise about the limits of his demarcation line, Falck again explained that it was "intended to terminate after passing between Singapore and Riouw". ${ }^{156}$ Later in the same conversation, he "disclaimed any desire to make the Line more extensive than his Note proposed; the measure would create jealousy in other Powers; he objected to including Borneo; a line going through it would generate a probability of collision". ${ }^{15 \tau}$

Falck received strong support for this view from the Directors of the East India Company, who had their own reasons for preferring that Borneo should not be mentioned in relation to any demarcation line. During the season of the north-east monsoon the Company's China-bound ships often had to steer by the so-called 'Eastern Passage', which took them south of Borneo, and then up to China by way either of Macassar Strait or of Djailolo Passage. Both these courses ran through the heart of an area in which, on Falck's original proposal, the Netherlands would have the sole right of forming settlements. This, the Directors pointed out, would be "most unsafe in time of war". 158

The British and Dutch plenipotentiaries agreed, therefore, that the proposed demarcation line should not include Borneo, and should not extend beyond Singapore Straits. But in that case, they asked themselves, what was to be gained by having a demarcation line at all? If its only purpose was to provide an Anglo-Dutch boundary in the area of the Straits, this could be more easily achieved by listing the actual islands involved and giving them either to the East India Company or to the Netherlands East Indies. Such a method would have the advantage of avoiding any suggestion in the Treaty - likely to be much resented by foreign powers - that the Dutch and British were dividing the Archipelago between them.

This reasoning was reflected in the draft proposals of February 1st, 1824 , which were referred to the appropriate government departments in The Hague and London for approval. The section of this draft which eventually became Article Twelve of the final Treaty ran as follows:

His Majesty the King of the Netherlands withdraws all

156 Dutch Records 'A', No. 30.

157 Ibid.

158 Secret Committee to Wynn, January 2nd, 1824. (Dutch Records 'A', No. 31). 
objections to the occupation of the Island of Singapore by the troops and subjects of Great Britain.

His Britannic Majesty, on the other hand, binds himself to ensure that no British establishments shall be set up on any of the remaining islands belonging to the ancient kingdom of Johore, and that no treaties are concluded by British authority with the Chiefs and Inhabitants of the same. ${ }^{159}$

In an accompanying note to the Dutch Government Fagel and Falck explained that the second paragraph of this article was considered necessary "to prevent the English from claiming any future right to form connections with or exert influence over the islands of Lingin, Rhio and the Carimons". Commenting on this in The Hague, Mr. C. Th. Elout, as adviser to the Colonial Minister, remarked that, in order to avoid confusion, it might be better to substitute for "any of the remaining islands belonging to the ancient kingdom of Johore", the phrase, "the remaining islands lying in those parts". ${ }^{180}$

Here is conclusive proof that the Twelfth Article of the Treaty of 1824 was not intended, in the Dutch view, to do more than set local limits to British and Dutch entitlements in the immediate area of Singapore. Either Falck's draft or Elout's amendment to it, had they been accepted, would have prevented innumerable misunderstandings and recriminations in the years to come. But both were rejected in favour of the vague and entirely unsatisfactory phrase, "any of the other Islands South of the Straits of Singapore".

It is difficult to see why any such change should have been thought necessary. It may well have been made because, during the final drafting of the Treaty, some one suggested the inclusion of one of those 'coverall' phrases, much beloved of lawyers, which are used to guard against unforseen omissions in lists of prohibited items. The legal mind, for example, might regard the listing of the "Carimon, Battam, Bintang, Lingin" islands as by itself insufficiently comprehensive, since there were many more islands besides these in Singapore Straits and near it, some of them not yet named. Nor was the wording of Falck's sug-

160 'Project-tractaat van 1 Februari 1824', Fagel and Falck to Ridder Reinhold (Dutch Foreign Minister), February 1st, 1824. (Kol., 1845, No. 442, Very Secret).

100 Nota of February 12th, No. 18. ('Diverse stukken over Borneo', ibid.) Elout van Soeterwoude, op. cit., p. 205. Van der Kemp, 'Londensch tractaat', pp. 171-2. 
gested draft, "islands belonging to the ancient Kingdom of Johore", quite conclusive either, since no one could claim to be able to define the limits of the ancient Sultanate of Johore with any degree of certainty. And the alternative proposed by Elout, "the remaining islands lying in those parts", though clear enough in its intention, was loosely phrased and might have led to legal quibbles later.

However this may be, the wording of Article Twelve of the Treaty of 1824 was changed, and in treaties, as in other legal documents, it is the written word that counts. From this time onwards the British Government were prohibited, by solemn obligation, from attempting to found settlements on "islands South of the Straits of Singapore". It would not be long before the exact meaning of these words was put to the test.

While the negotiations which led to the Treaty of 1824 were taking place in London, the Dutch authorities in the East had been strengthening their hold on Borneo. Residents had been installed at Bandjermasin on the South Coast and at Pontianak and Sambas on the West (with Assistant-Residents at Mampawa and Landak), and by 1825 these officials, helped by Government commissioners sent over from Java, had induced all the most important native princes in both areas to recognize Netherlands sovereignty. Attempts to subdue the independent Chinese mining communities of the west had been less successful, but it was confidently assumed in Batavia that before long they, too, would be ready to submit to Dutch rule.

In 1825 , however, war broke out in Java, and the heavy financial burdens which this struggle imposed on the Government, added to the serious economic situation which had arisen as a result of unwise monetary policies pursued by Governor-General van der Capellen, ${ }^{101}$ made further expansion in Borneo quite out of the question. For the next five years all spare resources, both of men and materials, had necessarily to be devoted to the war in Java. In the Outer Islands the policy of van der Capellen's successor, Commissioner-General du Bus, consisted in hanging on to what had been gained, and refraining from all action which might cause the Government undue expense. The principles which guided him have been summed up as, "No extension

161 G. Gonggrijp, Schets ener economische geschiedenis van Nederlands-Indië, pp. $90-1$. 
of territory; avoidance, if possible, of anything likely to lead to hostilities; but, at the same time, no cession of territory. ${ }^{102}$

During the administration of du Bus, therefore, Dutch Government establishments in western and southern Borneo, so far from being increased in size, were progressively cut down. In 1826 the province of Sambas was reduced to an Assistant-Residency, ${ }^{163}$ and all pretence at controlling the Chinese gold-mining kongsis was abandoned. A year later the Assistant-Residencies of Mampawa and Landak were abolished, ${ }^{104}$ and before long the only European officials left in the western part of the island were a Resident at Pontianak, an AssistantResident at Sambas, and two customs inspectors at Tajan. In the south, equally drastic cuts were made. By 1830 Dutch sovereignty over the whole of that vast area was being upheld by the Resident of Bandjermasin, C. L. Hartmann, assisted by a single European clerk. ${ }^{165}$

This policy of economy, inaugurated by du Bus, was applied with even greater firmness by his successors, van den Bosch, Baud, and de Eerens. Preoccupied as they were with moneymaking in Java, the Governors-General of the Netherlands Indies between 1830 and 1840 showed little interest in islands like Borneo, where no 'Culture System' could be profitably organized, and where existing Dutch settlements were regarded as costly nuisances. In 1833 the Residents of the South and West Coasts received instructions from Batavia that they must on no account interfere with the native princes or peoples amongst whom they were living unless Government property were directly threatened, ${ }^{186}$ and five years later the senior officials on the West Coast were forbidden even to set foot outside the immediate area of their Residencies. ${ }^{187}$

Throughout the decade of the 1830's, which Dutch writers stigmatize as the 'period of neglect' in the history of Borneo, ${ }^{168}$ the northern portion of the island lay open to colonization by other European powers.

162 H. van der Wijck, De Nederlandsch Oost-Indische bezittingen onder het bestuur van den Kommissaris-Generaal du Bus de Gisignies (1826-1830), p. 47.

163 Besluit of July 6th, 1826. (Stb., 1826, No. 27).

104 Resolutie of June 22nd, 1827, No. 1.

105 Besluiten of September 13th and November 17th, 1826. (Stb., 1826, Nos. 50 and 66). Almanak van Nederlandsch-Indië, 1830.

168 Resolutie of October 28th, 1833, No. 3.

107 Besluit of September 8th, 1838, No. 4. The ban on journeys into the interior was not officially revoked until 1847 (Besluit of April 20th, 1847, L" W, Secret), although a number of expeditions to the Chinese districts and the Upper Kapoeas were in fact authorized during the intervening period. 
A Dutch Government envoy had visited Brunei in 1823, and had presented a letter of friendship to the Sultan there, but no formal alliance had been concluded. ${ }^{108}$ Since then, despite the objections of officials of the West Coast administration, who were dismayed at the ease with which British goods imported into Brunei from Singapore could be smuggled across the border into Sambas - to the great detriment of the Government customs revenues - the authorities at Batavia had made no serious attempt to renew contacts with the Sultanate.

In 1831, for example, the Resident of the West Coast, D. J. van den Dungen Gronovius, suggested that a treaty of alliance and friendship should be negotiated with Brunei in order to forestall possible attempts by foreign nations or individuals to establish settlements there. $\mathrm{He}$ recommended, further, that the Sultan should be persuaded to cede four small provinces bordering on the northern frontier of Sambas - Lundu, Sematan, 'Sadoud' (Sadong?), and Sarawak - since, if these were added to the area already under Dutch control, the suppression of smuggling would be greatly facilitated. ${ }^{170}$ But the Government of Java accepted his proposals half-heartedly, and instead of sending to Brunei a Dutch plenipotentiary escorted by two warships, as he suggested, entrusted the mission to one of the Sambas perngerans, "an entirely unsuitable person", who remained at Brunei during nine months of 'negotiations', and then returned empty-handed. ${ }^{171}$

Seven years later, in July 1838, it was reported to the AssistantResident of Sambas, R. Bloem, that an English vessel had arrived at Sarawak from Singapore on a trading visit. In passing this information on to Batavia, Bloem pointed out that Sarawak had easy and direct communication with the interior of Sambas and that, under existing conditions, it was impossible to prevent English goods from being

168 P. J. Veth (op. cit., Deel ii, p. 443) gives $1827-46$ as the 'period of neglect', and other authors mention 1830-43, 1825-40, etc. On the whole, it seems preferable to date it from the introduction of the Culture System in Java (1830), when a policy of absolute abstention in the affairs of Borneo came into effect, to the arrival of James Brooke in Sarawak (1839), when a continuance of such a policy became dangerous.

160 Verschillende reizen en lotgevallen van $P$. P. Roorda van Eysinga, Deel iv, pp. 2-8.

170 Resident of the West Coast to the Governor-General, January 23rd, 1831, No. 31, L B. (Kol., 1842, No. 256/W, Secret).

171 Resoluties of March 12th, 1831, No. 50 (Art. iii), and October 28th, 1833, No. 3. See also 'Laboean, Serawak, de Noord-oostkust van Borneo, en de Sultan van Soeloe', TvNI, 1849, i, pp. 67-76. 
smuggled in by this route. The only way to keep English ships from coming there, he maintained, was to negotiate a contract with Brunei. ${ }^{172}$ The Government of Java replied that it was contrary to the Treaty of 1824 to strike preferential bargains with native princes, that "no hindrance may therefore be offered to free navigation and trade in the Indian Archipelago", and that, with regard to the conclusion of an agreement with Brunei, "there exists no necessity for it". ${ }^{173}$

Undeterred, Bloem pressed his case the harder by quoting extracts from the records of the Government salt warehouse at Sambas, which proved that the official salt trade (a Government monopoly at this time) had been seriously affected by smuggling through Sarawak. He also claimed that quantities of firearms and gunpowder were being imported legally by the same means, and that these would soon get into the hands of Chinese miners or Malay pirates. But his arguments were of no avail. On February 8th, 1839, he received a letter from Batavia, advising him that "with regard to the trade of the English at Sarawak, it is considered that nothing need be done; this trade should therefore be allowed to take its own course". ${ }^{174}$ No more was said about a contract with Brunei.

Six months later James Brooke, in his yacht, the Royalist, arrived off the entrance to Sarawak River.

172 Assistant-Resident of Sambas to the Governor-General, July 17th, 1838, No. 90. (Quoted in 'Nota: Commissoriaal', L' G8, Secret, Buitenzorg, November 13th, 1841 : Kol., 1842, No. 256/W, Secret).

173 Besluit of November 13th, 1838, L* C ${ }^{3}$, Secret.

174 Besluit of February 8th, 1839, No. 14, Secret. 


\section{CHAPTER IV}

\section{THE WHITE RAJA OF SARAWAK}

James Brooke was born in 1803 at Benares, where his father was in the service of the East India Company. At the age of twelve he was sent to school in England, and after a somewhat haphazard education was gazetted as an ensign in the Bengal army in 1819. He served with distinction in the first Anglo-Burmese War, and early in 1825 received a severe wound which caused him to be invalided home. Half way through 1829 he began the return journey to India, but his ship was delayed by unfavourable weather, and he found himself stranded at Madras with insufficient time to reach Calcutta before his five-year period of convalescent leave was due to expire. He promptly resigned the Company's service, and set off on a sight-seeing tour of China and the Eastern Seas.

In 1834 he visited the Far East again, this time on a trading venture. The expedition was not a success financially, but it whetted Brooke's appetite for further adventures in distant lands. When his father died the next year and left him $£ 30,000$, he was in no doubt about what he would do with his inheritance. "I am in treaty", he wrote in March 1836, "for a schooner of 142 tons burden, which I propose shall carry me round the world". ${ }^{175}$ This was the yacht, Royalist. After a short 'working-up' cruise in the Mediterranean, he sailed for the East in December 1838 and arrived at Singapore five months later.

Before leaving England Brooke published a prospectus of his voyage entitled, 'Expedition to Borneo'. ${ }^{178}$ His main purpose at this time was scientific inquiry. He planned to explore the coastlines of northern Borneo and Celebes, making surveys, penetrating inland if the inhabitants seemed friendly, and picking up general knowledge of the

175 Quoted in Gertrude L. Jacob, The Raja of Sarazuak, Vol. i, p. 60.

176 This paper was published in full in The Private Letters of Sir James Brooke (Vol. $i$, pp. 2-33), in an abridged and slightly altered form in Captain the Hon. Henry Keppel, The Expedition to Borneo of H.M.S. Dido for the Suppression of Piracy, Vol. ii, Appendix 1, and was summarized in the Journal of the Royal Geographical Society, 1838, pp. 443-8. The quotations which follow are taken from Templer's version, Vol. i, pp. 4-9. 
area. On this occasion he was not interested in trade himself, but hoped that the information he obtained on his travels would be useful to the British commercial world. Nevertheless, he was never really in sympathy with this world and strongly opposed the view, held by many of his contemporaries, that civilization automatically followed in the steps of trade. He always felt a sincere concern for native welfare, and considered that European commercial expansion had all too frequently led in the East to the brushing aside of what he described as the "indefeasible rights of the Aborigines". Even at this early stage in his career he was asserting that the activities of European governments "must be directed to the advancement of the native interests and the development of the native resources, rather than, by a flood of European colonization, to aim at possession only". He never departed from this view.

The 'Expedition to Borneo' also shows that Brooke arrived in the East in 1839 with definite preconceptions about the Government of the Netherlands Indies. "The policy of the Dutch", he wrote, "has at the present day reduced the 'Eden of the Eastern Wave' [i.e. the Malay Archipelago] to a state of anarchy and confusion as repugnant to humanity as it is to commercial prosperity". Brooke had a great admiration for Sir Stamford Raffles, and believed that the East India Company's withdrawal from Java in 1816 had been a major mistake. "The policy of the British in the Indian Archipelago", he declared, "has been marked by vacillation and weakness... The position of the Dutch nation in the Far East, though apparently so imposing. is in reality far from strong, and their power would easily sink before the vigorous opposition of any European country... The fact must always be borne in mind that the Dutch are masters of the Archipelago only because no other nation is willing to compete with them".

Brooke's original intention had been to begin exploring Borneo at Marudu Bay, in the northern part of the island. But his plans changed while he was waiting at Singapore for the arrival of the south-east monsoon. "I have settled to sail for Borneo Proper [Brunei]", he wrote to friends at home. "The rajah of the country is represented as favourable to Europeans, and has lately behaved in a civilized and proper way to a shipwrecked crew who fell into his power. On my way to the capital I propose looking at the coast as minutely as circum-

177 Brooke to Templer, June 18th, 1839. (John C. Templer (Ed.), The Private Letters of Sir James Brooke, K.C.B., Rajah of Sarawak...., Vol. i, p. 55. Hereafter cited as Letters). 
stances will allow, and visiting Sararwak - the place whence small vessels bring the ore of antimony". ${ }^{177}$ Governor Bonham of the Straits Settlements gave him letters of introduction to the court at Brunei, and the Singapore Chamber of Commerce asked him to take a present on their behalf to Raja Muda Hassim, the Brunei noble who had befriended the shipwrecked British seamen. Hassim was known to be in Sarawak at the time, and this gave Brooke a definite object for his voyage.

In 1839 the territories claimed by the Sultan of Brunei extended from the far north of Borneo down to the frontier of Sambas at Tanjong Datu. The rivers along these seven hundred miles of coastline supported small populations of Malays and a few Chinese. The Malays lived partly by trade, partly by piracy, and partly by oppressing the Dyaks and other aborigines of the interior. The government of Brunei made scarcely any pretence at controlling them. The numerous chiefs who ruled the area acknowledged the formal suzerainty of Brunei, but sent the Sultan little or no tribute. Many of the rivers were in the hands of independent and piratical Arab sharifs who recognized no superior authority at all.

Sarawak was one of the less important provinces at the southern extremity of the Sultanate. It was not marked on any British Admiralty chart and very little is known of it before Brooke's time. The Portuguese historian, de Barros, included 'Cerava' in a list of the principal ports of Borneo during the early sixteenth century, ${ }^{178}$ and Leyden's 'Sketch of Borneo' (published in 1814) mentions the place with disfavour, as the headquarters of "the piratical chief which lately cut off the ship Commerce". ${ }^{178}$ In the early 1820's, according to a Dutch account, there were about a hundred Malays at Sarawak, most of them pirates; the Chinese had only three houses; while two Brunei perngerans carried on the government and extracted three koyans of padi and two pikuls of birds'-nests a year from the local Dyaks. ${ }^{180}$

Since then Sarawak had gained a certain notoriety as one of the most suitable places through which contraband goods like salt and

178 Quoted by J. R. Logan, 'Notices of European intercourse with Borneo....', Journ. Ind. Arch. 1848, p. 503.

179 John Leyden, 'Sketch of Borneo', originally printed in the Verhandelingen van het Bataviaasch Genootschap der Kunsten en Wetenschappen, Vol. vii (1814), and later reproduced in J. H. Moor, Notices of the Indian Archipelago...., Appendix.

180 C. L. Blume, 'Toelichtingen aangaande de nasporingen op Borneo van G. Müller', De Indische Bij, 1843, p. 147. 
opium could be smuggled across the border into Sambas. A small trade in antimony had also grown up between it and Singapore. The antimony ore was mined some twenty-five miles from Kuching by forced Dyak labour, and was sold by the governor of Sarawak, Pěngeran Makota, to Rappa and Henry, and to Moses and Johannes, two Singapore commercial houses. This trade, however, had died out by $1839 .{ }^{181}$

About four years before Brooke arrived at Singapore in the Royalist, a Brunei pĕngeran named Usop, who was an illegitimate son of the Sultan of Brunei's grandfather, began to cause trouble in Sarawak. In return for a sum of money to be paid on delivery, he arranged for the country to be made over to a brother of the Sultan of Sambas. Hearing about this, the Brunei Government naturally made objections. and to gain his end Usop roused the local inhabitants to rebellion, the Sultan of Sambas agreeing to supply the insurgents with arms and ammunition. ${ }^{182}$ Usop had little difficulty in finding a pretext for general revolt, since the population was becoming restive under Pĕngeran Makota's harsh rule, and there was particularly strong resentment against the system of forced, and unpaid, labour which had been introduced in the antimony mines. The rebels sent messages to the AssistantResident of Sambas in May 1839, saying that they wished to be taken under Dutch rule, but the Government of Java made no move to help them. ${ }^{183}$ It was to suppress this rebellion that Raja Muda Hassim, an uncle by marriage of the reigning Sultan of Brunei and the chief minister of the Sultanate, had come to Sarawak.

Brooke's yacht, the Royalist, arrived off Kuching, the principal town of Sarawak, on the morning of August 15th, and he and Hassim met for the first time later on the same day. When Brooke inquired how the civil war was progressing, the Raja Muda assured him that "there was no war, but merely some child's play among his subjects". He indicated, however, that it would be convenient if his visitor - and

181 Brooke to Templer, June 30th, 1850. (Letters, ii, p. 301). S. Bleekrode, 'Antimonium en platina van Borneo', TvNI, 1858, i, p. 110.

182 Brooke to Templer, September 25th, 1841. (Letters, i, p. 114).

183 Governor-General of the Netherlands Indies to the Minister of the Colonies, November 30th, 1841, No. 578. (Kol., 1842, No. 256/W, Secret). 'Laboean, Serawak....'T TvNI, 1849, i, pp. 74-5. Dedel to Aberdeen, March 20th, 1846. (C.O. 144/1).

184 Brooke's journal, August 15th, 1839. The extensive journals which James Brooke kept of his experiences in the Far East are to be found in Keppel's Expedition to Borneo of H.M.S. Dido...., (London, 1846, 2 vols.), and in Captain Rodney Mundy, Narrative of Events in Borneo and Celebes.... (London, 1848, 2 vols.). 
also his visitor's armed yacht - would remain at Sarawak for a while "as a demonstration against the rebels". ${ }^{184}$

But Brooke was eager to have a closer look at the nearby rivers, and on this occasion did not stay long at Kuching. He spent the next month examining the Samarahan and the Lundu, which lie to the east and west of the capital respectively. Returning to Sarawak, he approached the Raja Muda about the possibility of opening up trade with Singapore, recommending that the ships of every nation, and not merely those of the British, should be admitted to all Brunei territories. Hassim's expressions of goodwill towards the English encouraged him. and he formed the opinion that Singapore, if it so desired, might "gain the entire trade of the north-west coast of Borneo from Tanjong Datu to Marudu Bay". ${ }^{185}$ When Brooke left Sarawak on September 19th, Hassim parted from him with great regret, saying, "Tuan Brooke, do not forget me". After a brief inspection of a pirate settlement on the Sadong River, Brooke set out for an extended tour of southern Celebes.

It was not until the end of August 1840 that he visited Sarawak again. When he arrived at Kuching he found to his surprise that the civil war was in much the same state as it had been the year before. Hassim asked for his assistance, and this time Brooke agreed to provide what support he could. "After our friendly communication", he wrote. "I could not, as an English gentleman, desert him". ${ }^{188}$

Brooke spent the next two months trying to convince a reluctant Malay army that it could not win a war merely by sitting behind its stockades and waiting for the enemy to surrender. Early in November he threatened to desert his timorous allies altogether, and to prevent this the Raja Muda offered him the government of Sarawak. This was the first occasion upon which such a proposal had been made, but Brooke declined it, feeling that if he accepted he would be guilty of taking an unfair advantage of another's extremity. He realized, moreover, that a grant made while the war was still in progress and, consequently, signed 'under duress', would be difficult, if not impossible, to enforce later. ${ }^{187}$ But he agreed to continue his support for Hassim's army and, after many delays and one sharp engagement, in which he himself led a charge, he finally induced the rebels to lay down their arms.

185 Dido, i, p. 75.

186 Brooke admitted later, however, that he had also been impelled by a natural curiosity to see how wars were fought in Borneo. (Ibid., pp. 142 and 151).

187 Ibid., p. 210. 
Soon afterwards Hassim offered him the government again, and this time Brooke accepted it. In February 1841 he received the title of 'Resident of Sarawak'. The written agreement, however, drawn up by the Raja Muda to give effect to this appointment, gave the English visitor permission to live at Kuching only in order to "seek for profit". Nothing was said about the transfer of sovereign rights which his previous conversations with Hassim had led Brooke to expect. When the Englishman drew attention to this, Hassim explained that the agreement was intended to serve merely as something which could later be shown to the Sultan, and did not represent the real understanding between them. ${ }^{188}$ Brooke was suspicious, but did not press the matter further at this stage. He undertook to re-open the antimony trade, and paid a short visit to Singapore to buy a vessel suitable for the purpose.

When he returned to Sarawak, however, he found that the Raja Muda appeared to be in no hurry to make over the government. Nor was he able to induce either Hassim or anyone else to supply more than a token quantity of antimony ore in exchange for the goods he had brought back with him from Singapore. Months dragged by with no apparent prospect of a final settlement. With the crews of two vessels to pay and an establishment to keep up at Kuching, Brooke found that his financial resources were dwindling rapidly. But then two unexpected events brought matters to a crisis. The Honourable Company's steamer, Diana, arrived at Sarawak to inquire after a shipwrecked British crew who were reported to be in captivity at Brunei, and her approach, Brooke noted, "put the Raja Muda and the rest in an awful fright"; ${ }^{189}$ while, shortly afterwards, an agent of Pĕngeran Makota, the governor of Sarawak, attempted to poison Brooke's interpreter with arsenic. Incensed at this, Brooke decided to make a trial of strength. He landed an armed party from the Royalist, loaded her guns, and threatened to attack Makota. Two hundred Dyaks took his part, and Makota was abandoned except for a few immediate followers and slaves. "After this demonstration", wrote Brooke, "affairs proceeded cheerily to a conclusion. The Raja was active in settling; the agreement was drawn out, sealed, and signed; guns fired, flags waved; and on the 24th September, 1841, I became the governor of Sarawak, with the fullest powers". ${ }^{100}$

In July of the following year Brooke visited Brunei for the first

188 Ibid., p. 213.

189 Brooke to Templer, September 25th, 1841. (Letters, i, p. 113).

100 Dido, i, p. 252. Brooke to Templer, September 28th, 1841. (Letters, i, p. 118). 
time. The Sultan welcomed him effusively, and seemed quite willing to confirm the grant of Sarawak already made by Hassim. "I wish you to be there", he told Brooke, "I do not wish anybody else; you are my amigo, and it is nobody's business but mine; the country is mine, and if I please to give you all, I can" ${ }^{101}$ The Sultan, however, as Brooke soon found, was practically an imbecile, and not even master in his own house, much less in distant portions of his dominions like Sarawak. The most influential of his advisers in the absence of Hassim was Pěngeran Usop, who by this time had returned to the capital. Somewhat surprisingly in view of his past attitude, Usop agreed to support Brooke's cause, and persuaded the Brunei council of pengerans to recommend to the Sultan that a definitive deed of cession should be signed. The formalities were completed at ten o'clock in the evening of August 1st, 1842, a date which, Brooke hoped, would be "marked with a white stone in the annals of Sarawak". ${ }^{192}$ In return for an annual tribute of $\$ 2,500$, and on condition that neither the customs nor the religion of the inhabitants would be interfered with and that the country would not be alienated without his previous consent, the Sultan ceded Sarawak to Raja Brooke "with all its revenues and dependencies". ${ }^{193}$

The White Raja now had a clear title to his kingdom as well as a tremendous personal reputation along the entire north-west coast of Borneo. To the people at large he was the 'Tuan Bèsar', the Englishman who had miraculously ended the civil war in Sarawak and, in so doing, had performed a feat which not even the Raja Muda of Brunei had been able to achieve. But he knew that his rule would never be secure so long as it depended merely on prestige and paper agreements. For one thing, he was surrounded by enemies, both actual and potential; the pirate strongholds to the north, in particular, would have to be subdued before his little kingdom could flourish. He realized, too, that his own fast diminishing private fortune was quite inadequate to develop the resources of the country. His ultimate objective, he once said, was to transform Borneo into "a second Java". To achieve this he would need generous support from the commercial world and also from naval forces. The first essential, therefore, was to secure some form of British Government recognition for his raj.

191 Dido, i, p. 325.

102 Ibid., p. 332.

193 Cf. S. Baring-Gould and C. A. Bampfylde, A History of Sarawak under its two White Rajahs 1839-1908, p. 85. 
The first move in the White Raja's campaign for recognition was the publication early in 1842 of his Letter from Borneo. In form this was a private communication to a friend, James Gardner, but it was intended to be laid before the Colonial Secretary, Lord Stanley. "Although anxious to see a settlement under British influence and protection established here", Brooke declared, "I am indifferent whether it be formed under my own superintendence or under the direction of others, and am willing to transfer the rights and interests $I$ have acquired to any successor who, with better means or better support, shall be able to carry my views into execution... On public grounds only I request the support of Government, or the assistance of the commercial community". ${ }^{104}$

It is important to notice the strings which Brooke attached to his proposal. He was willing to surrender his rights in Sarawak, but only to those who undertook beforehand to 'carry his views into execution'. The meaning of this phrase was made clearer in a letter he wrote the following year: " $\mathrm{My}$ object is to secure to the natives a permanent good, beyond the chances of my life. Of course, in the first place, I apply to the British Government; to the merchants; to the religious societies: if all are deaf or indifferent, it is then I propose applying to others more willing, and likewise able, to carry my views into effect". ${ }^{105}$ In other words, Brooke was prepared to turn even to foreign nations for the support he needed, provided they would accept his terms; nothing must be allowed to interfere with the welfare of the people of Sarawak.

Shortly before the Letter from Borneo was published Brooke appointed a London merchant, Henry Wise, to act as his agent in England. Wise threw himself into the task of publicising Sarawak with immense enthusiasm. From the end of 1842 onwards he kept the Prime Minister, Sir Robert Peel, and other members of the Cabinet under a continuous barrage of letters and memoranda extolling Sarawak's great commercial possibilities. He had copies of his correspondence with Brooke printed in a series of handsome folio editions and circulated to appropriate Government Departments. In numerous interviews with ministers and under-secretaries he stated his principal's case

$194 \mathrm{~J}$. Brooke, $A$ Letter from Borneo, with notices of the country and its inhabitants, p. 6.

195 Brooke to Templer, March 22nd, 1843. (Letters, i, pp. 240-1).

196 MacGregor to Wise, November 1st, 1844. (A Selection from Papers relating to Borneo and the Proceedings at Sarawak of James Brooke, Esq....., First and Second Series, 1846, p. 67. Hereafter cited as Borneo Papers). 
"with great spirit and, at the same time, with discretion", as a Board of Trade official later declared, ${ }^{106}$ and he was equally successful in persuading various Chambers of Commerce and East India Associations in England and Scotland to demand from the Government a more vigorous policy in Borneo. A similar propaganda campaign was being carried on by Brooke's friends, Gardner and Templer, but Wise was by far the most efficient of the earlier protagonists for Sarawak.

Because of the bitter quarrel which later developed between Brooke and his London agent, however - a quarrel for which the latter was largely, though not entirely, responsible - most writers on Sarawak have tended to belittle the importance of Wise's contribution. But a tribute which was paid to him by the First Lord of the Admiralty, the Earl of Haddington, at the end of 1844 shows that in some quarters at least there was real admiration for the achievements of Brooke's London agent. "I shall always be ready, if required", Lord Haddington told Wise, "to state the sense I entertain of the zeal and intelligence with which you have advocated the views of Mr. Brooke and, as I believe, the interests of the country, especially of the mercantile community, in the whole of this matter". ${ }^{107}$ Another observer, Thomas Church, the Resident Councillor at Singapore, made a similar comment in a letter to Wise in 1847. "I am quite satisfied", said Church, "and he must know it too, that Brooke would never have been in his present high and honourable position unless through your influence and labour; this he can never forget or adequately requite". ${ }^{108}$

Wise's first success came at the beginning of 1843. As a direct result of his representations, ${ }^{109}$ a naval survey vessel, H.M.S. Samarang (Captain Sir Edward Belcher), ${ }^{200}$ which was on the point of leaving Falmouth for a seven-year tour of duty in the Eastern Seas, was given last-minute instructions by the Admiralty, first, to proceed to Sarawak to inquire into Brooke's position and, secondly, to report on the pos-

187 Haddington to Wise, October 12th, 1844. (Ibid., p. 62).

188 Church to Wise, May 27th, 1847. (C.O. 144/2).

109 Foreign Office Minute of June 25th, 1846. (C.O. 144/1).

200 Captain (later Admiral) Sir Edward Belcher (1799-1877), who figures prominently in this story, was one of the most experienced and, according to contemporary accounts, one of the most heartily disliked of the Royal Navy's survey officers during the mid-19th Century. He conducted hydrographic surveys of the Pacific Ocean and Bering Straits (1825-8), the West and North Coasts of Africa (1830-3), the western coasts of both North and South America (1836-9), and, as commander of H.M.S. Samarang, of the coasts of China, Formosa, the Philippines, and the Indian Archipelago (1842-7). He served in the second China War, and in 1852 led an unsuccessful expedition to the Arctic to search for the lost explorer, Sir John Franklin. 
sibility of developing some coal seams which were known to exist at Brunei. ${ }^{201}$

The presence of coal in Borneo was first reported by an American, G. Tradescant Lay, who visited Brunei in 1837 in the trading vessel, Himmaler. Lay's attention was drawn by the inhabitants to a small island not far from the capital called Pulau Churmin ('Mirror Island'), because of the brilliance of the sun's reflection on the outcrops of coal to be seen there. He was assured that ample supplies of the mineral could be obtained at many places near Brunei, and he himself found further signs of it at Kianggi. ${ }^{202}$ Four year later Captain Congalton of H.E.I.C.S. Diana refuelled his ship with Brunei coal when he called to pick up survivors from a British merchantman which had been wrecked nearby. Samples were forwarded to Calcutta for analysis, and the Government Coal Committee there reported that they were equal to the "best English" in quality, and "well adapted for steam purposes". ${ }^{203}$ Consequently, Wise was able to give a thoroughly practical reason why the British Government should interest themselves in the northwest coast of Borneo at this time. Steamers were being employed more and more in the Eastern Seas and in the trade with China, and a supply of coal east of the Straits of Malacca which did not have to be transported all the way from England would be a great advantage. Wise also hinted that the Dutch might possibly get in first if the British Government did not secure a monopoly of Borneo coal while they had the chance. Brooke's great influence with the Brunei rajas, he argued, would make an exclusive coal grant easy to obtain. ${ }^{204}$ Before the Samarang had time to reach Borneo, however, Brooke had begun to receive naval support from another quarter.

When the first China War came to an end in August 1842, H.M.S. Dido (Captain the Hon. Henry Keppel) ${ }^{205}$ was released from the China Station and ordered to Malacca to assist in suppressing piracy and in

201 Captain Sir Edward Belcher, Narrative of the Voyage of H.M.S. Samarang.., Vol. i, p. 18.

202 G. Tradescant Lay, Notes made during the Voyage of the Himmaleh in the Malayan Archipelago, pp. 138-9.

203 Report of November 28th, 1841. (C.O. 144/1). Indian Government Political Letter of April 18th, 1842. (F.O. 12/3).

204 Wise to Sir Robert Peel, December 13th, 1842. (Borneo Papers, pp. 1-2).

205 Captain the Hon. (later Admiral of the Fleet Sir) Henry Keppel (1809-1904) joined the Navy in 1822 and, because of his family connections (he was a son of the Earl of Albemarle), achieved rapid promotion in the service, reaching the rank of Post-Captain in 1837. He is best known for his attacks on the Borneo pirates, but he also helped to suppress the slave trade on the West 
protecting British trade in the Indian Archipelago. While the Dido was at Singapore making ready for an attack on the Borneo pirates who had recently dealt harshly with the crews of the Sultana, Lord Melbourne, and other British ships, Captain Keppel made the acquaintance of James Brooke and offered him a passage back to Sarawak. Keppel and Brooke were thus able to discuss the whole pirate problem at length and they came to the conclusion that "the only way to strike at the root of the evil would be to destroy the piratical strongholds in the interior". ${ }^{206}$

Brooke was particularly anxious that an effective blow should be struck at the pirates of Saribas and Sĕkrang. These were two fierce marauding communities who lived in the area of the Batang Lupar, some sixty miles east of Kuching. ${ }^{207}$ They were known and feared up and down the whole length of the West Coast of Borneo, and their depredations sometimes extended as far as Bandjermasin and Celebes. ${ }^{208}$

Each of these two communities consisted of distinct groups of Malays and Dyaks. The Malays belonged to the orang laut, the 'people of the sea', and had been in possession of their strongholds in Borneo since about the middle of the eighteenth century. When they arrived on the north-west coast, instead of fighting with the much more numerous Dyak aborigines, they took them into partnership, and gradually trained them in the art of piratical warfare. To begin with the Dyaks served merely as oarsmen in the prahus of the Malays, and when a trading vessel was captured they contented themselves with the heads of the crew, leaving the plunder to their superiors. ${ }^{209}$ But by 1840 their period of apprenticeship was complete, and they had become dangerous pirates on their own account. Even so, Malay organization was still needed for large-scale operations. Half-bred Arab sharifs, whose claim to be descended from the Prophet gave them a certain mystical glamour, and who combined fine executive ability with complete lack of scruple,

Coast of Africa, commanded a naval brigade with distinction at the siege of Sevastopol, and fought an engagement with the Chinese at Fatshan Creek during the second China War (1857). He was promoted Admiral of the Fleet in 1877 and retired in 1879. His name is commemorated by 'Keppel Harbour' at Singapore.

206 Admiral Sir Henry Keppel, A Sailor's Life under Four Sovereigns, Vol. i, p. 290.

207 The Sĕkrang (Skrang, Sakarran) River is a tributary of the Batang Lupar, and the Saribas enters the sea a dozen miles north of the Batang Lupar Estuary.

208 Brooke, Letter from Borneo, p. 13.

209 Captain the Hon. Henry Keppel, $A$ Visit to the Indian Archipelago in H.M. Ship Meander, Vol. i, p. 128. 
were the 'master minds' behind most Saribas and Sĕkrang pirate expeditions.

When not engaged in piracy, the Dyaks of both rivers went on headhunting forays into the territory of their neighbours. Other Dyak tribes were addicted to this practice too, but they normally attacked only their hereditary enemies; the Saribas and Sĕkrang took heads indiscriminately. Brooke wrote of the former that they were "robbers by land and pirates by sea; their hand is against every man and every man's hand is against them". ${ }^{210}$

The Brunei pengerans who governed the coast had learnt to play on this Dyak weakness for head-hunting. By threatening to turn the Saribas or the Sĕkrang loose on a particular river, they found that they could quickly reduce its inhabitants to submission. ${ }^{211}$ But, as so often happens in such cases, the servants, realizing their power, began to turn against their masters. When the civil war was at its height in Sarawak, for example, the Saribas sent word to Raja Muda Hassim that they would not be available to support the government because they were busy fighting a war of their own elsewhere. ${ }^{212}$

This was the anarchic and confused situation that James Brooke inherited. When, soon after assuming control in Sarawak, he ordered the Saribas and Sĕkrang to stop their attacks on the tribes which now owed him allegiance, they answered his warnings with defiance. The chief of the Saribas hung a basket on a high tree, and boasted that it would soon contain the White Raja's head. ${ }^{213}$ It was high time, Brooke decided, that these troublesome "savages" were taught a lesson. ${ }^{214}$

In May 1843 H.M.S. Dido, with Brooke and Keppel on board, arrived at Kuching, and almost immediately Raja Muda Hassim made a formal request for British naval assistance against the pirates. This demand may possibly have been prompted by Brooke, but there is no reason to suppose that Hassim made it unwillingly; having identified his fortunes with those of the White Raja, he had as much to gain from the extermination of the enemies of Sarawak as had Brooke. "This is to inform our friend", Hassim wrote to Keppel, "that there are certain great pirates of the people of Saribas and Sěkrang in our neighbourhood, seizing goods and murdering people on the high seas.

210 Brooke to Templer, October 19th, 1839. (Letters, i, p. 74).

211 Dido, i, pp. 232 and 247.

212 Ibid., p. 148.

213 Ibid., p. 312.

214 Brooke to his mother, June 22nd, 1842. (Letters, i, p. 198). 
They have more than three hundred war-prahus, and extend their ravages even to Bandjermasin; they are not subject to the government of Brunei; they take much plunder from vessels trading between Singapore and the good people of our country. It would be a great service if our friend would adopt measures to put an end to these piratical outrages". Keppel replied that he would take "speedy measures to suppress these and all other pirates", and decided to begin with the Saribas, because their strongholds were reported to be the best fortified. ${ }^{215}$

At the beginning of June an oddly assorted squadron sailed from Kuching to carry out Keppel's plan. The force consisted of a pinnace, two cutters, and a gig from the Dido, and a miscellaneous collection of craft belonging to Brooke's Dyak allies. Most of the Dyaks who joined the expedition were hoping for a chance to revenge themselves on their traditional enemies. According to Keppel, the 'Sow' Dyaks entered the fray "eager for heads and plunder". ${ }^{216}$ This was natural, since most Sarawak tribes had suffered from the raids of the Saribas pirates at one time or another. But there were obvious dangers in employing such ill-disciplined auxiliaries for work that was designed to pacify rather than inflame. Brooke was later subjected to heavy criticism for 'setting a Dyak to catch a Dyak' in this way. That he was able to control his native allies at all was a remarkable tribute to his powers of leadership.

The combined force quickly reduced the main Saribas strongholds at Padeh, Paku, and Rimbas, burning the settlements and fortifications to the ground, and capturing or destroying considerable numbers of guns and war-boats. ${ }^{217}$ The loss of their houses and stockades was a small matter to the pirates, for these could easily be rebuilt. In time, boats and guns, too, could be replaced. But the moral effect of Keppel's attack was tremendous. Never before had anyone dared to seek out the dreaded Saribas in their hiding-places. But now a strange new enemy had appeared, with heavy guns, superior marksmanship, and mysterious weapons, ${ }^{218}$ who was able to break through the strongest river obstacles and penetrate defences once thought impregnable. The chiefs of Padeh,

215 Dido, ii, pp. 26-8.

216 Ibid., p. 46.

217 Keppel to Vice-Admiral Parker, June 23rd, 1843. (P.P., 1852-3, LXI, pp. 284-6).

218 Keppel was told later that "a common signal sky-rocket" fired during one of the night actions "caused more horror and consternation among the enemy than any thing else". (Dido, ii, p. 58). 
Paku, and Rimbas quickly came to terms, promising to mend their ways and attend a peace conference at Kuching. The expedition returned in triumph to Sarawak.

Keppel was eager to follow up this success with a similar attack on the pirates of Sěkrang, but much to his regret the Dido was almost immediately recalled to Hong Kong. Brooke, however, was not to be long without support from the Royal Navy. Less than a fortnight after Keppel's departure, Captain Sir Edward Belcher arrived at Kuching in H.M.S. Samarang.

In accordance with the first part of his instructions Belcher spent some time examining conditions at Sarawak, and was about to leave for Brunei to have a look at the coal seams there when the Samarang ran on a sand bank. With Brooke's assistance the vessel was soon salvaged, but not before a whole concourse of ships had appeared in Sarawak River anxious to assist her. As a result, when Belcher and Brooke set out soon afterwards on their way to Brunei, the Samarang had in company H.M.S. Harlequin, H.M. Steamer Vixen, the yacht, Royalist, and the British merchant brig, Ariel ${ }^{219}$ - "Quite an imposing fleet", Brooke commented, "and one sufficient to terrify the natives of the entire Archipelago". 220

It was certainly quite powerful enough to impress the Sultan and pèngerans of Brunei. When Belcher and Brooke arrived at the capital, the Sultan showed himself very ready to listen to their proposals. Belcher obtained the royal signature to a preliminary treaty with Great Britain, whereby the government of Brunei promised to foster trade, suppress piracy, and keep clear of alliances with other foreign powers, ${ }^{221}$ and Brooke secured something his friends in England had been urging on him for some time - the cession in perpetuity of Sarawak. Brunei coal, on the other hand, Belcher found disappointing. The quality was good, but steam machinery would have to be installed to make the seams workable. ${ }^{222}$

Leaving Brunei early in September, the Samarang continued on her way to Hong Kong, and did not reappear on the north-west coast of Borneo until August 1844; by this time Captain Keppel of the Dido

219 Frank S. Marryat, Borneo and the Indian Archipelago, p. 24. H.M.S. Wanderer and H.E.I.C.S. Diana also came to Sarawak to offer their services but, finding that these were not required, returned to Singapore. (Belcher, op. cit., Vol. i, pp. 55-7).

220 Mundy, op. cit., Vol. i, p. 354.

221 F.O. 12/2.

222 Belcher op. cit., Vol. i, p. 60. 
had returned to Sarawak, and had begun an enthusiastic assault on the strongholds of the pirates of Sĕkrang.

For this attack the Dido's boats were reinforced not only by five hundred of Brooke's Dyak auxiliaries, but also by four cutters belonging to the Honourable Company's steamer, Phlegethon, which had been borrowed from the Straits Government for the occasion. The forces available to Keppel were thus even more formidable than those which had so thoroughly subdued the Saribas the year before. Patusen, the chief Sěkrang stronghold on the Batang Lupar, was "very extensive", Keppel said afterwards, "and, after being well looted, made a glorious blaze" lasting three days. ${ }^{223}$ Fifty-six guns and vast quantities of ammunition were captured, including a ton and a half of gunpowder; and over two hundred war boats were destroyed. ${ }^{224}$ The force then proceeded up the Batang Lupar and its three main tributaries, the Sěkrang, Undup, and Lingga, demolishing the fortifications and cutting through the obstructions which lay across its path.

The Samarang returned to Sarawak just in time to participate in the final stages of these operations, but, finding that there was little for him to do, Captain Belcher took his ship back to Singapore. There he discovered that Governor Butterworth had a most unusual commission for him. The Indian Government had recently advised that a 'European female' was thought to be in captivity at Ambong, a small pirate settlement on the north-west coast of Borneo, about half-way between Brunei and Marudu Bay. The Governor asked Belcher to find out whether there was any truth in this rumour, and offered him the steamer, Phlegethon, to assist him in the search. ${ }^{225}$

A short time before, while the Dido and Samarang were still at Kuching, Belcher, Keppel, and Brooke had come to the conclusion that Raja Muda Hassim and his extensive entourage at Sarawak ought to be removed as soon as possible; ${ }^{228}$ their presence was hindering the progress of the country and was acting as "a dead clog on the advancement of the Dyak interests". 227 Belcher had thereupon offered the services of the Samarang to transfer them to Brunei, and now in Singapore he had been given a task which would take the Samarang past Brunei in the course of her search for the mysterious European

223 Dido, ii, p. 90.

224 Keppel to Governor Butterworth, September 4th, 1844. (P.P., 1851, LVI, Pt. i, p. 127).

225 Belcher, op. cit., Vol. i, p. 163.

228 Brooke to Wise, July 14th, 1844. (F.O. 12/2).

227 Belcher, op. cit., Vol. i, p. 159. 
female at Ambong. ${ }^{228} \mathrm{He}$ therefore advised Brooke that he was sending the Phlegethon to Sarawak, and that the Raja Muda and his train should be told to make ready for a passage in her without delay.

So it came about that in October 1844 Brooke and Belcher once more made the journey to Brunei aboard the Samarang, while the Phlegethon was sent on ahead with the Raja Muda and a motley collection of his friends and relations. As soon as they arrived at Brunei, the two Englishmen requested an audience with the Sultan. This was granted, although it was noticeable that the Brunei court's reception was not so cordial as it had been the year before.

Nevertheless, the Sultan readily agreed to all his visitors' demands. Pĕngeran Usop was removed from his unofficial position as chief minister at the court, and Hassim was installed in his stead. Fresh assurances were also given of the Government of Brunei's firm desire to be on friendly terms with the British nation. ${ }^{22 \theta}$ By themselves, however, such expressions of goodwill were worth little, and Brooke decided to take the opportunity of securing a more permanent guarantee of the Sultan's continued good faith. In response to a direct suggestion from the White Raja, the Government of Brunei addressed the following letter to Queen Victoria: "The Sultan and the Raja Muda Hassim desire to gain the friendship and aid of the Queen of England for the suppression of piracy and the encouragement and extension of trade; and to assist in forwarding these objects they are willing to cede to the Queen of England the Island of Labuan, and its islets, on such terms as may hereafter be arranged by any person appointed by Her Majesty".230

Meanwhile in London Brooke's energetic agent, Henry Wise, had been persevering with his campaign to secure official British recognition for Sarawak. For a time Wise appeared to be making good progress. The Admiralty agreed that Belcher should be instructed to report on Sarawak's possibilities as a naval base, and Brooke, hearing of this, began to toy with the idea of being made a British governor. ${ }^{231}$ But after this initial success Wise found it increasingly difficult to penetrate

228 Whether or not a white woman was in fact being held captive at Ambong at this time has been much debated by writers on Borneo. Belcher, at any rate, found no trace of one.

229 Belcher to the Admiralty, November 10th, 1844. (F.O. 12/3).

230 Belcher, op. cit., Vol. i, pp. 176-7.

231 Brooke to Templer, April 13th, 1843. (Letters, i, p. 248). 
the wall of Government apathy. The Foreign Secretary, the Earl of Aberdeen, refused to grant Brooke any diplomatic or consular status, ${ }^{282}$ and the Colonial Office opposed all suggestions that Sarawak should be converted into a Crown Colony.

In August 1842, however, an event took place in the Far East which greatly strengthened Wise's hand - the signing of the Treaty of Nanking at the end of the first China War. This agreement opened Shanghai and other Chinese ports to the commerce of the world, and provided for the cession to Great Britain of the island of Hong Kong. Immediately Borneo, particularly its north-west coast, increased in strategic significance. The expected growth of British trade with the new Chinese 'treaty ports' meant that coaling stations, harbours of refuge, bases from which Chinese and Malay piracy could be attacked, and other shipping facilities would soon be urgently needed east of the Straits of Malacca. "It will, sir, of course, not fail to strike you", Wise wrote in his pompous way to Sir Robert Peel, "that many advantages will accrue to the British nation by founding a Crown colony on the western side of Borneo, particularly as Sarawak would then form the connecting link between the British possessions of Singapore and Hong Kong". 233

Wise was also in the strong position of being able to offer to the British Government an almost unlimited choice of sites where such a colony might be established. Sarawak was an obvious first preference, because it already possessed a stable government; but if not Sarawak, then anywhere else on the north-west coast of Borneo that Her Majesty's Government might be pleased to select. This was a large claim, but Wise was justified in making it. By 1842 the White Raja's influence in northern Borneo was so great that he was in a very real sense the master of local politics. "I am supreme!! with the Rajas of Borneo", Brooke wrote in July of that year, "and whatever I require I can procure. Do not imagine that a title to property here is as difficult to obtain as one in England ... If I desired I might have a dozen rivers besides Sarawak". ${ }^{234}$ Moreover, in a contemporary letter to Wise, Brooke made it clear that whatever he could win for himself he could also secure for the British Government. "In the present state of Borneo Proper", he declared, "for British protection against pirates and against

232 Melville, Wise \& Co. to Brooke, December 5th, 1842. (Borneo Papers, pp. 3-4).

233 Wise to Peel, March 12th, 1844. (Ibid, p. 26).

294 Brooke to the Rev. C. Johnson, July 19th, 1843. (Ibid., p. 23). 
themselves, the Rajas would cede any quantity of territory". ${ }^{235}$

Brooke consequently became very impatient at the Government's slowness to make up their minds whether they would accept his offer of Sarawak or not. In his opinion the establishment of a Crown Colony in Borneo ought not to be regarded as an end in itself, but merely as the first step in a much larger programme of British expansion through the Indian Archipelago. His own achievement, he considered, had pointed the way. With a little energy British influence could easily be extended from Borneo through the Sulu Archipelago and as far as New Guinea. By a series of agreements with native princes and by acquiring rights which, if need be, might be allowed to lie dormant for the time being, Great Britain could obtain nominal sovereignty over a vast stretch of territory which would be clear of the Dutch on the one hand, and the Spaniards on the other, and which could later be exploited when the necessary capital resources became available.

Such plans, Brooke realized, lay far in the future. The immediate necessity was to establish permanent British influence over the Sultanate of Brunei. As early as March 1843 he had remarked in a letter to Wise that the cession of Labuan, a small island at the northern end of Brunei Bay, could easily be obtained from the Sultan. ${ }^{238}$ A settlement here would not only serve as a base for expeditions against the pirates, but would also provide a useful observation post from which a watch could be kept on happenings at the Sultan's capital. At that time, however, the British Government were still engaged in weighing up the pros and cons of Brooke's proposal that recognition should be afforded to Sarawak, and he had therefore not bothered to approach the Sultan regarding a possible cession.

As the months went by without any sign that Sarawak was ever to receive British recognition, Brooke and Wise came to the conclusion that a small island at the entrance to. Brunei Bay, though admittedly a poor substitute for Sarawak as a Crown Colony, would at least provide a valuable point d'appui from which British power could one day be expanded along the Borneo coast. Wise then put up the suggestion that the Government would be more ready to agree to a settlement at Labuan if the Sultan of Brunei made a present of the

235 Brooke to Wise, March 13th, 1843. (Ibid., p. 11).

233 Ibid. Shortly afterwards Brooke wrote in his journal: "The proper course for the British Government to pursue would be to obtain the monopoly of the Borneo coal with the island of Labuan". (Mundy, op. cit., Vol. i, p. 339). 
island outright. ${ }^{237}$ Brooke saw the value of this proposal, and induced the Sultan and Hassim to make the necessary offer of cession when he visited Brunei with Sir Edward Belcher in October 1844.

When he took this step Brooke was acting entirely on his own initiative. In official circles in England he was still regarded as a private gentleman who had been invested by a Malay Sultan with autocratic powers over a small native state in Borneo. He had not been given authority to carry out negotiations of any kind and, because of this, he believed that the Government were wasting valuable opportunities in not making better use of his unique position. He began to suspect that he was being regarded as a schemer and a job-hunter, ${ }^{238}$ and at one time even had serious thoughts of returning home in despair. ${ }^{238}$

But at last half-way through 1844, two and a half years after Brooke's campaign to obtain recognition had begun, the Government took a first tentative step along the road which was eventually to lead to British dominion over a third of Borneo. On August 20th the Earl of Haddington (First Lord of the Admiralty) asked Wise if the White Raja would be willing to accept an unpaid appointment, other than that of consul. Wise replied by return of post that the Raja would be very willing to do so. ${ }^{240} \mathrm{~A}$ fortnight later Haddington wrote again to say that although a regular diplomatic appointment for Brooke was still "a matter for consideration" the Government had decided "to treat him in all respects as a confidential agent", and, further, that Captain Drinkwater Bethune, R.N., was being sent to Borneo "to report on the best place for the establishment of a naval station and harbour of refuge". ${ }^{241}$

On February 17th, 1845, Bethune arrived at Kuching and handed Raja Brooke a letter from the Foreign Secretary, appointing him British confidential agent in Borneo. ${ }^{242}$ In accordance with his new instructions, Brooke hurried to Brunei to inform the Sultan and Raja Muda Hassim that their hopes of British support in the struggle against

237 That this particular proposal was made by Wise and not by Brooke is shown by a letter which Brooke wrote to his London agent immediately after the cession had been obtained. "You mention in your letter", Brooke told Wise, "how desirable it would be to possess Labuan, and your mention has induced me to gain a paper from the Sultan and Muda Hassim, offering the Island to the British Government". (Brooke to Wise, October 31st, 1844: F.O. 12/2).

238 Brooke to Templer, December 31st, 1844. (Letters, ii, p. 41).

239 Brooke to Johnson, May 1844. (Ibid., p. 24).

240 Wise to Haddington, August 21st, 1844. (Borneo Papers, p. 53).

241 Haddington to Wise, September 6th, 1844. (Ibid., p. 54).

242 Dido, ii, p. 163. Aberdeen to Brooke, November 1st, 1844. (F.O. 12/2). 
the pirates would soon be realized. The Sultan was obviously gratified at this news, and inquired when the English were coming to Labuan, adding, "I want to have the Europeans near me". ${ }^{243}$

There was a particular reason why the Government of Brunei should be anxious for British protection at this time. Reports had been received that a powerful Arab sharif named 'Usman, the chief of the Lanun pirates of Marudu Bay, was threatening to attack the capital. 'Usman was in league with Pĕngeran Usop, who since his dismissal from office the previous October had become the leader of the anti-British faction in Brunei politics. Hassim consequently feared that the two allies were planning a coup d'état, which would probably be aimed at himself. Usop was jealous of the Raja Muda's place in the Sultan's favour and anxious to regain his former pre-eminence, while 'Usman strongly resented the orders he had recently received from Hassim proclaiming that he would be treated as an outlaw unless he abandoned the practice of piracy.

The Sultan and the Raja Muda therefore made a formal request to Brooke, and also to Bethune who had accompanied Brooke to Brunei in H.M.S. Driver, for British naval protection. "The pirates are exceedingly displeased we have made an alliance with the English", the Sultan told Bethune, "and we would strongly recommend an attack upon Marudu, with a view to destroying the pirates who reside at that place". ${ }^{244}$ Brooke hastened to Singapore to enlist the help of RearAdmiral Sir Thomas Cochrane, the Commander-in-Chief of the Far Eastern Station, and on August 8th, in response to this plea, a British squadron of eight warships appeared off Brunei with the Admiral himself in command aboard his flagship, H.M.S. Agincourt. ${ }^{245}$

In the course of an interview with the Sultan, Cochrane demanded reparation from the Government of Brunei for illegally detaining two lascars from the crew of the Sultana, a British merchantman which had been struck by lightning and captured by pirates four and a half years before. ${ }^{246}$ The Sultan and Hassim promptly denied all responsibility, and laid the blame on Pĕngeran Usop - which indeed was where it belonged - saying that they would be much obliged if the British Navy would take steps to punish him for his past misdeeds. Usop was

243 Dido, ii, p. 166.

244 Sultan of Brunei to Bethune, March 6th, 1845. (P.P.. 1852-3, LXI, p. 302).

245 The other ships were: H.M.S. Vestal, H.M.S. Daedalus, H.M.S. Cruiser, H.M.S. Wolverine, H.M. Steamer Vixen, and H.E.I.C. Steamers Pluto and Nemesis.

248 Cochrane to the Sultan of Brunei, August 1845. (C.O. 144/1). 
sent for and, when he failed to appear, a shot was fired over his house. With a show of bravado he immediately ordered his own private batteries to reply, and a few minutes later the house was in ruins and its owner was fleeing for his life into the jungle. ${ }^{247}$

Cochrane then ordered his squadron up the coast to Marudu Bay in order to dispose of Sharif 'Usman. On August 19th, after cutting through a heavy boom which guarded the entrance to the main pirate stronghold, five hundred and fifty marines and bluejackets advanced to the attack. 'Usman's forces were overwhelmed and his village burnt to the ground. "Marudu", Brooke wrote in his journal next day, "has ceased to exist". 248

The triumphant outcome of the 'Battle of Marudu' gave the White Raja reason to believe that the first part of his self-appointed mission in Borneo was complete. The power of all the most dangerous pirate communities on the north-west coast had at last been shattered, though periodic visits from British warships would still be needed if the lesson they had received was to be driven home. Brooke himself had been granted an official position under the Foreign Office, and the British Government were beginning to listen to his views. Captain Bethune was busy looking for a suitable site for a naval station and harbour of refuge, a government with strong British sympathies had been established at Brunei, and Brooke's own status as Raja of Sarawak was more secure than it had ever been before.

Two main factors were responsible for his remarkable success : first, his astonishing capacity for handling native peoples, which amounted at times almost to genius; and, secondly, the generous support, both direct and indirect, which he had received from the Royal Navy and, to a lesser extent, from the steamers of the East India Company's service.

When Brooke first arrived in Borneo, he had been announced by letters from a British Governor, S. G. Bonham. This had helped to create among the inhabitants an impression, later confirmed by the timely arrival of the steamer, Diana, that the British Government were behind him. Brooke himself noticed that the problem of dealing with

247 Dido, ii, pp. 170-1. Usop later made an unsuccessful attempt to seize power in Brunei, and when this failed retired to his feudal estates at Kimanis. He was subsequently captured while temporarily off his guard and strangled on orders from Hassim. (Cf. E. Owen Rutter, The Pirate Wind, pp. 172-3).

248 Dido, ii, p. 175. Brooke to Aberdeen, September 19th, 1845. (F.O. 12/3). 
piratical Dyak tribes was made easier for him because they believed he was backed by all the power of his country. ${ }^{248} \mathrm{He}$ had not deliberately set out to create this impression. On the contrary, he was always most careful to avoid any suggestion that he had come to Borneo other than as a 'private gentleman'. But the belief was nevertheless widely held. This did not escape the attention of Colonel Butterworth, the Governor of the Straits Settlements. Reporting Keppel's success against the pirates of Sĕkrang in 1844, Butterworth told the Government of India that "a Mr. Brooke" had been a member of the expedition. "It necessarily follows", he went on, "that the people of the petty states through which the expedition passed... will suppose that we were supporting $\mathrm{Mr}$. Brooke and the Raja Pěngeran Muda Hassim". 250

Captain Keppel's decision to attack the Saribas and Serkrang pirates was of the utmost value in consolidating Brooke's rule in Sarawak. There was no particular reason why Keppel should have selected these two communities for his first assaults. Indeed, he might well have begun with the Lanuns of Tempasuk or Marudu Bay, who were unquestionably more dangerous to European shipping. He made his decision, however, and later gave this reason for it: "It was with unfeigned pleasure that I then found that, while performing my duty in the suppression of piracy, I was, at the same time, rendering the greatest assistance and support to an individual in [Brooke's] praiseworthy, novel, and important position". ${ }^{251}$ A most happy coincidence of duty and inclination for the future of Sarawak!

The assistance given to the White Raja by Sir Edward Belcher was less direct, but equally valuable. In August 1843, it will be remembered, the Samarang, supported by four other British vessels, including two warships, carried Brooke to Brunei. It was on this occasion that he obtained from the Sultan the cession of Sarawak in perpetuity. A year later, Belcher's offer to convey Raja Muda Hassim and his family to Brunei in the steamer, Phlegethon, enabled Brooke to restore to power in the capital a government favourable not only to British, but also to his own, interests. Here again the presence of British warships on his doorstep - literally so, for Brunei River, the 'main street' of the capital, ran past the royal palace - can hardly have left the Sultan unmoved. The scene during the final conference between Captain

249 Dido, i, p. 297.

250 Butterworth to the Secretary to the Government of India, September 14th. 1844. (P.P., 1851, LVI, Pt. i, p. 126).

251 Dido, ii, pp. 1-2. 
Belcher, Raja Brooke, and His Highness of Brunei has been described by an eye-witness in these words: "The barge was so placed that the assassination of $\mathrm{Mr}$. Brooke and the Europeans would have been revenged on the first discharge of our gun by the slaughter of hundreds; and in the main street lay the steamer, with a spring on her cable, her half ports up, and guns loaded to the muzzle ... The platform admitted one of the steamer's guns to look into the audience chamber, the muzzle was pointed directly at the sultan, a man held the lighted tow in his hand". 252

Neither Keppel nor Belcher, however, acted at any time contrary to their orders in providing support for the White Raja. Faced with the problem of carrying out their duties in a country which neither had visited before, they turned automatically to the one Englishman who could claim to know the real state of affairs on the north-west coast of Borneo. Some of the assistance they offered was prompted by friendship and admiration, but most was given unconsciously. The mere presence of their warships, ${ }^{253}$ coupled with the fact that Brooke talked to them on equal terms, was enough to persuade the impressionable inhabitants of Borneo that the White Raja who ruled in Sarawak was a great man indeed. As Belcher remarked when the Samarang dropped anchor off Kuching only a fortnight after the Dido had left the Borneo coast, "The arrival of our frigate at this particular period was estimated... beyond doubt, by the people of Sarawak, as a jealous interest on the part of the British Government in the affairs of Mr. Brooke". 254

252 Marryat, op. cit., pp. 114-15. The author was a midshipman in H.M.S. Samarang.

253 According to Keppel, the Dido was the first square-rigged vessel that had ever entered Sarawak River. (Dido, ii, p. 6).

254 Belcher, op. cit., Vol. i, p. 22. 


\section{CHAPTER V}

\section{JAMES BROOKE AND THE DUTCH GOVERNMENT}

By August 1845, through the united efforts of Raja Brooke and the Royal Navy, all local obstacles to the creation of a British colony on the north-west coast of Borneo had been removed. A pro-British government was in power at Brunei, the Sultan had announced his willingness to cede the necessary territory, and the Malay and Dyak pirates along the coast had not yet recovered from the devastating attacks of Keppel and Sir Thomas Cochrane. But no one could tell how long this favourable situation would last. Although British influence at Brunei had been greatly strengthened by the expulsion of Pèngeran Usop and by the destruction of Sharif 'Usman's stronghold at Marudu Bay, a powerful opposition party still existed at the Sultan's court. The members of this party had long been reaping huge profits as the leading entrepreneurs of the local piracy and slave trade, and they rightly foresaw that a continuance of the recent British attacks would destroy their livelihood entirely. From Brooke's point of view, therefore, it was vital that the British Government should come to a decision on the question of a colony in Borneo before it was too late, before another Brunei palace revolution placed power in the hands of those who might not only persuade the Sultan to withdraw the offer of Labuan but might also compel him to denounce all past agreements to co-operate with Great Britain in the suppression of piracy and the promotion of trade.

The British Government, however, had no intention of being hurried into a new colonizing venture on the coast of Borneo. Their slowness was no doubt partly due to the easy pace at which bureaucracy moved in those days, but it was also caused by the large number of Government Departments that had to be consulted. Both the Admiralty and the Foreign Office had already had a finger in the pie: the Admiralty had issued instructions to Belcher to report on Sarawak and had ordered Bethune to search for a site for a naval station, and the Foreign Office had appointed the White Raja as their Confidential Agent in Borneo. But neither the Treasury, which would have to supply the 
money, nor the Colonial Office, which would have to do most of the work, had yet given their consent to any plan for the creation of a new Crown Colony.

The Admiralty's interest in Borneo was primarily strategic, and was the direct result of increasing British naval responsibilities in the Far East. The abolition of the East India Company's monopoly of trade with China in 1834, and the rise in the volume of the China trade generally after the opening of the 'treaty ports' in 1842, had greatly complicated the Royal Navy's task of protecting British merchant shipping east of Singapore. During the Napoleonic Wars Great Britain had acquired an extensive chain of naval bases covering the main sea routes to India and the East up to and including the Straits of Malacca. Ascension Island, the Cape of Good Hope, the Mauritius, Chagos, and Seychelles groups, Ceylon with its fine harbour at Trincomalee, and the Maldive, Laccadive and Andaman Islands were all either captured during the war or ceded to Great Britain at the peace treaty. But between Singapore and the China Coast there was a gap of nearly fifteen hundred miles without a single friendly port; along the whole length of this important maritime highway there was no base from which the Royal Navy could operate against Chinese or Malay pirates, and no harbour of refuge in which merchant shipping could shelter from the typhoons of the South China Sea. The absence of naval facilities in these waters had been of much less consequence when the East India Company's monopoly was in force, and when (as, for example, during the Napoleonic Wars) China-bound East Indiamen had been herded together in annual convoys which often did not touch land between the Cape of Good Hope and Canton. Under the convoy system, naval protection had been provided by a warship sailing in company with the merchantmen for the whole voyage, ${ }^{255}$ and numerous naval bases had not then been so necessary. ${ }^{256}$ But by the 1840 's the China convoys had disappeared, and British ships were trading independently to China in ever-increasing numbers from England, India, Singapore, and elsewhere, without any restrictions on their movements. To protect them, locally-based naval patrols were needed, and these in turn required more naval stations. The acquisition of Hong Kong in 1842 helped to solve the problem, but the fifteen hundred mile gap between Singapore and the China Coast still remained. The Admiralty

255 C. Northcote Parkinson, Trade in the Eastern Seas, 1793-1813, p. 308.

250 Ships sailing independently, like the country ships of India, were expected, and were sufficiently well armed, to look after themselves. 
therefore turned their attention to the north-west coast of Borneo, which was situated conveniently between the two.

A second reason for the Admiralty's interest in Borneo was the discovery of new coal deposits. It had been common knowledge since about 1841 that coal existed near Brunei, and during his visit of October 1844 Sir Edward Belcher was able to confirm rumours that there were further outcrops on Labuan as well. Samples of coal from both places were sent for examination to Sir Henry de la Beche, the Director of the British Ordnance Survey, who reported that they were "of a quality quite equal to our best Newcastle". ${ }^{257}$ It was questionable whether Borneo coal could be produced at competitive prices, since the Admiralty's own supplies were being landed at Hong Kong for as little as $\notin 1-17-0$ a ton, ${ }^{258}$ but there were obvious advantages in having a 'self-supporting' coal depot in the China Seas. If communications with Great Britain were cut in time of war, for example, coal would have to be brought all the way from Bengal or Australia, the only other sources of supply.

In July 1844 Raja Brooke's campaign for a British colony in Borneo received powerful support from John Crawfurd, a former Resident of Singapore. Prompted by Wise, ${ }^{259}$ Crawfurd drafted a long memorandum on Brooke's proposal for the information of the Admiralty. "I am of opinion", he wrote, "that a settlement on the north-west coast of Borneo... would be highly advantageous to this country - as a coal depot for steam-navigation, as a means of suppressing Malayan piracy, as a harbour of refuge for ships disabled in the China Sea and, finally, as a commanding position during a naval war. The island of Labuan has been pointed out for this purpose; and as far as our present limited knowledge of it will allow me to judge, it appears to possess all the necessary qualities for such a settlement". ${ }^{260}$

Crawfurd's advocacy cleared away any lingering doubts the Admiralty may have had regarding the desirability of a naval station on

257 Belcher, op. cit., Vol. i, p. 186.

258 Cochrane to the Admiralty, April 10th, 1845. (P.P., 1852-3, LXI, p. 301).

259 Wise submitted Crawfurd's name to the British Government, together with those of John Anderson (author of Practical and Commercial Considerations relative to the Malayan Peninsula, 1824), T. C. Robertson, Governor S. G. Bonham, and Dr. Horsfield, as persons qualified to recommend in the matter. Anderson, in particular, gave Wise valuable assistance, even to the extent of 'ghosting' some of his earlier letters to the Admiralty. (Anderson to Aberdeen, July 14th, 1845: F.O. 12/3).

260 C.O. 144/1. Crawfurd's memorandum also appears in full in the Borneo Papers and in Keppel's Dido, ii, pp. 212-26. 
the Borneo coast, and led directly to the dispatch of Captain Drinkwater Bethune the following November. ${ }^{261}$ Bethune was instructed to pick out a position with a good anchorage, room for merchant vessels, sufficient depth of water for large ships, and shelter against the prevailing winds. He was also told to make an examination of all known coal-fields in the area and to report where the best quality coal was to be found. Moreover, any locality which satisfied these requirements must be easily defensible and conveniently situated to act as a base from which expeditions might be launched against the pirates. Labuan had been recommended by Brooke and Crawfurd, but other possible sites must be investigated too. Above all, Bethune was "cautiously to avoid all intercourse with those districts settled by the subjects of the King of the Netherlands". ${ }^{262}$

The Colonial and Foreign Offices were kept informed of these developments, and by the end of 1844 both had agreed with the Admiralty that a naval station on the Borneo coast was "indispensably necessary". ${ }^{263}$ The Treasury, too, had been induced to accept this view. ${ }^{264}$ But neither the Colonial Secretary, Lord Stanley, nor the Foreign Secretary, the Earl of Aberdeen, were prepared to go farther. A naval station was the most they would agree to. They could see no justification for a full-scale colonial establishment in Borneo, with a governor, appropriate administrative services, and a military garrison. What was required, they felt, was a settlement more on the model of Ascension Island, a naval base in the South Atlantic which was exclusively under the Admiralty's jurisdiction, and ranked as one of Her Majesty's ships. ${ }^{265}$ For this reason the Colonial Office were involved only incidentally in the earlier inter-departmental discussions regarding Labuan, but the Foreign Office, who had to keep an eye on the activities of other nations in the Far East as well as safeguard Great Britain's general strategic interests there, were much more in-

261 F.O. $12 / 4$.

262 'Instructions from the Lords Commissioners of the Admiralty to Captain Bethune, R.N., to inquire into the State of Coalfields in the Eastern Archipelago', November 1st, 1844. (P.P., 1852-3, LXI, pp. 313-15).

263 Aberdeen to Brooke, November 1st, 1844. (F.O. 12/2).

264 Foreign Office Minute of June 25th, 1846. (F.O. 12/4).

205 In September 1845 Lord Aberdeen mentioned in conversation with Baron Dedel, the Dutch Ambassador in London, that the British Government were thinking of placing "a ship's company" on Labuan. (Dedel to Baud, September 23rd, 1845, Private: Buit. Zaken, No. 3133). Ascension Island remained under Admiralty supervision until 1922, when it became a dependency of St. Helena. 
timately concerned. The nation which was most likely to object to an increase in British influence in Borneo, and whose counter-claims Her Majesty's Government had to be ready to combat, was, of course, the Netherlands.

The Dutch Government first became aware of the existence of James Brooke when an article describing his projected visit to the Far East appeared in a Paris journal. ${ }^{288}$ The implication of this article (published in October 1838 in the Gazette de France) was that the voyage of the Royalist marked the beginning of a British campaign to seize control of the whole of Borneo. From Singapore, the Gazette complained, Brooke would be able "easily to undertake excursions to the various parts of the great island of Borneo, possession of which the English have long coveted. Already masters of New Holland, once they have taken possession of Borneo they will announce that everything between the two belongs to them by droit d'enclave. Who will be able to hinder them? The wonder is that they have not declared themselves masters of all Polynesia. But that will come..." ${ }^{287}$ Soon afterwards the United Service Journal, disclosing that Rear-Admiral Sir Frederick Maitland had sailed from Singapore with six warships to bring pressure on China in the current opium dispute, announced that once the Admiral had completed his duties in China, he "purposed going to Borneo to arrange another important mercantile affair with the Dutch and British merchants". ${ }^{288}$ Both these reports were wildly inaccurate, but the Dutch were not to know this at the time, and accepted them as indications of a re-awakening British imperialism in the Indian Archipelago. So far as Brooke's expedition was concerned, however, their apprehensions were temporarily allayed when the Colonial Minister pointed out that the British Government were hardly likely to be behind an enterprise involving only one small schooner of 140 tons burden. ${ }^{268}$

When Brooke arrived in the East in mid-1839, therefore, his explanation that he was merely a private individual with no govern-

206 J. C. Baud to the Minister of the Colonies, November 10th, 1838, No. 399. (Buit. Zaken, No. 3133).

267 'Ethnographie et géographie: exploration de l'archipel asiatique : établissement des Anglais à Bornéo', Gazette de France, October 28th, 1838. At this time an Anglo-French dispute over Tahiti was causing bitter feelings on both sides of the Channel.

288 'Letter from Portsmouth', October 21st, 1838, United Service Journal, 1838, iii, p. 401.

269 Minister of the Colonies to the King, November 23rd, 1838. (Kol., 1838, No. 499 , Secret). 
ment connections of any kind, and no object other than the pursuit of knowledge, was readily accepted in Batavia. Governor-General de Eerens granted permission for the Royalist to use ports in the Netherlands Indies without paying harbour dues, and recommended her owner to the good offices of Dutch officials. ${ }^{270}$ But some of Brooke's actions during a visit he paid to Celebes in 1840 revived Dutch suspicions as to his possible secret motives. On one occasion he gave a quantity of muskets and gunpowder to a Bugis chief who was in revolt against the Netherlands Indian Government. On another he tried to open a communication with the Raja of Bone, and this attempt failed, according to information received in Batavia, only because the Raja remained faithful to the obligations he owed to his Dutch overlords. ${ }^{271}$ These incidents persuaded the Netherlands Indian Government that Brooke's real aims were not "private and scientific" as had previously been supposed, but "official and political". ${ }^{272}$

When news of the occurrences in Celebes reached The Hague, the Colonial Minister, J. C. Baud, asked his colleague, the Minister of Foreign Affairs, to find out whether or not the British Government were actively supporting Brooke. ${ }^{273}$ This request was passed to Baron Dedel, the Dutch Ambassador in London, ${ }^{274}$ who reported that he could see no cause for anxiety, since an English friend had positively assured him that Brooke had not been entrusted "with any political or commercial scheme whatever". ${ }^{275}$ The Dutch Government's apprehensions were consequently quietened once again.

Brooke himself, meanwhile, had returned to Borneo from Celebes, and had begun 'meddling', as contemporary Dutch accounts phrased it, in the Sarawak civil war. The Assistant-Resident of Sambas imme-

270 Governor-General to the Minister of the Colonies, February 8th, 1841, No. 2, Secret. (Buit. Zaken, No. 3133.) Brooke to Aberdeen, March 10th, 1846. (F.O. 12/4.) Dedel to Aberdeen, March 20th, 1846. (C.O. 144/1.)

271 Governor of Makassar to the Governor-General, April 30th, 1840, No. 181" (Kol. 1841, No. 66, Secret.) Dedel to Aberdeen, March 20th, 1846. (C.O. 144/1.)

272 Governor-General to the Minister of the Colonies, July 22nd, 1840, No. 24, $L^{2} G^{3}$. (Kol., 1841, No. 54, Secret).

273 Minister of the Colonies to the Minister of Foreign Affairs, February 6th, 1841. (Kol., 1841, No. 54, Secret).

274 Minister of Foreign Affairs to the Minister of the Colonies, February 16th, 1841, No. 4, Secret. (Kol., 1841, No. 66, Secret).

275 Letter to Ambassador Dedel of March 25th, 1841. No signature appears on this letter in the form in which it is included in the Dutch records. Dedel stated merely that it came from "a member of the Royal Geographical Society" (under the auspices of which Brooke's original expedition had been undertaken). (Dedel to Verstolk van Soelen, March 26th, 1841, No. 26: Buit. Zaken, No. 3133). 
diately addressed a curt note to him, requesting, in so many words, that he would mind his own business, and allow the inhabitants of Sarawak to mind theirs. This letter is not mentioned anywhere in the White Raja's journals, private correspondence, or public dispatches. In 1846, moreover, he told Lord Aberdeen that up to that time he had received two letters only from the Dutch authorities in Borneo, one dealing with the escape of some prisoners from Sambas gaol, and the other asking him to help in recovering a debt owed to the Sultan of Sambas by a Chinese kongsi which had migrated to Sarawak. ${ }^{276}$ Yet it seems most unlikely that he should not have received a letter of this importance. Its text ${ }^{277}$ is as follows:

\section{"Dear Sir,}

A report has reached me that you are interfering in the affairs of Sarawak. I sincerely hope the rumour is entirely without foundation. You cannot be ignorant that all meddling in the political affairs or party dissensions at Sarawak by British subjects would be a violation of Article 5 of the Treaty between their Netherlands and British majesties, and I must therefore protest against any interference of the kind, if you have been drawn into the contest now going on among the people of Sarawak.

I trust this notification will be sufficient, and that you will feel the propriety of withdrawing from the scene of contest and leaving the Sarawak people to manage their own affairs.

I am placed under the necessity of informing my Government of the report of your course, in order that it may adopt such measures as may put an end to unjustifiable political interferences.

Accept the assurances of my esteem,

Yours truly,

R. Bloem,

Adst. Resident van Sambas".

But in any case, whether he received this letter or not, Brooke certainly paid no attention to it, and continued on his way undisturbed.

In August 1841 the senior Dutch official in western Borneo com-

276 Brooke to Aberdeen, March 10th, 1846. (F.O. 12/4).

277 R. Bloem to J. Brooke, November 14th, 1840, No. 98. (Kol., 1842, No. 256/W, Secret. Also reproduced in Emily Hahn, James Brooke of Sarawak, p. 66). 
plained to his Government that the English interloper at Sarawak was trading extensively in muskets and gunpowder. Since it was quite impossible, he reminded the Governor-General, to prevent smuggling across the Sambas border, an influx of firearms into Dutch Borneo would almost certainly cause trouble in Sanggau and Sintang, two districts with easy communication with Sarawak by river. ${ }^{278}$ A month later the Netherlands Indian Government were further informed that Brooke had been installed as sovereign ruler of Sarawak. This persuaded the Governor-General that a firm stand must be taken if British pretensions in Borneo were to be checked, and he advised Minister Baud that he was planning to establish a Dutch Government post in the Sultanate of Brunei. ${ }^{278}$

This information arrived at The Hague almost simultaneously with a dispatch from London, containing a copy of the Letter from Borneo - the document by which Brooke first offered to cede Sarawak to the British Government. It was no longer possible to doubt the reality of the White Raja's political aims. He had now publicly announced that it was his hope and intention to establish permanent British influence over the north-west coast of Borneo. Yet, on Baud's advice, and contrary to the wishes of the Governor-General, the Dutch home Government made no move to check him. The Colonial Minister's reasoning was as follows: in the first place, since the Government of the Netherlands Indies did not themselves possess any sovereign rights in the Sultanate of Brunei, they would not be justified in attempting to exclude other powers from that part of Borneo; in the second place, existing Dutch settlements on the West and South Coasts were such poor advertisements for the island as a whole that foreign nations were unlikely to want to compete seriously for possession of it. The British, indeed, already controlled most of the trade of Borneo from Singapore. "T think it will be advisable", Baud therefore told King William, "for us to let [Great Britain] have a free hand, and not cause an argument by the creation of a post" in Brunei. ${ }^{280}$

Events were soon to show that James Brooke constituted the greatest threat to Dutch power in Borneo since Sir Stamford Raffles, but,

278 Commissaris-Inspecteur Donker to the Governor-General, July 31st, 1841, No. 310/8, Secret. (Kol., 1842, No. 256/W, Secret).

279 Governor-General to the Minister of the Colonies, November 30th, 1841, No. 578. (Ibid.)

280 Minister of the Colonies to the King, May 19th, 1842, $\mathrm{L}^{\mathrm{a}} \mathrm{A}$, No. 236, Secret. (Buit. Zaken, No. 3133). 
curiously enough, it was not the actions of the White Raja of Sarawak that provoked the first Dutch protests against British interference in the island, but those of another, and less famous, private adventurer.

In February 1844 the Young Queen and the Anna, two British trading brigs chartered in Hong Kong, and commanded by an enterprising Scot named the Hon. Erskine Murray, arrived at Koetei on the East Coast of Borneo. The local Sultan gave a warm welcome to Murray and his companions, and expressed the hope that theirs would be the first of many similar visits by British merchants. But when the leader of the expedition asked permission to take up permanent residence at Koetei in order to protect British trade, his request was peremptorily refused. This should undoubtedly have served as a warning, but Murray very foolishly allowed his ships to be lured up the Mahakam River to Tenggarong, a small town some twenty-five miles from Samarinda. The Sultan immediately set up batteries of guns along the river banks to prevent their escape. Murray threatened to destroy the town if not allowed to proceed, but his bluff failed, and he and his men had to fight their way down to the coast amid a storm of hostile fire. There, when they had almost succeeded in running the gauntlet of the Sultan's guns, they were engaged by a large flotilla of pirates and three members of the expedition, including its commander, were killed. ${ }^{281}$

Erskine Murray's plan to visit Borneo, like Brooke's, was first brought to the notice of the Dutch Government by a newspaper report. In November 1843 an article appeared in the Friend of China, explaining that the objects of a voyage soon to be undertaken by two British merchant vessels to the coasts of Borneo were colonization and the promotion of trade. ${ }^{282}$ The Dutch Government naturally deduced from this that Murray was hoping to emulate the achievements of the White Raja of Sarawak. ${ }^{283}$ From the Dutch point of view, however. the two cases were entirely different. The Sultanate of Koetei, unlike Sarawak, was part of the Netherlands Indies, and when the British

281 Friend of China, April 20th, 1844. Singapore Free Press, May 23rd, 1844. Hong Kong Register, April 23rd, 1844. See also W. Cave Thomas, Murray's Expedition to Borneo (published 1893), and Marryat, op. cit., p. 45.

282 Friend of China, November 2nd, 1843 (reproduced in the Javasche Courant, December 30th, 1843).

283 Minister of the Colonies to the King, July 27th, 1844, No. 343, Secret. (Buit. Zaken, No. 3133).

This may well have been Murray's true aim, though the Government of India expressed the opinion later that he had not been interested in settlement, only in trade. (Secretary to Government, Fort William, to the Secret Committee. November 23rd, 1844: F.O. 12/3). 
press began demanding that the Royal Navy should be sent to avenge Murray's death, the Dutch decided that it was time to make a stand. Any British naval action against Koetei, Ambassador Dedel warned the Earl of Aberdeen, would be "a derogation of Netherlands sovereignty". ${ }^{284}$ The Foreign Secretary replied that his Department had no official knowledge of the activities of the Hon. Erskine Murray, and that, in any case, Great Britain would take no action which might infringe on Dutch sovereign rights. ${ }^{285}$ A small naval expedition was sent to Koetei by the Netherlands Indian Government themselves in March 1844, but Murray's murderers were not brought to justice. Nevertheless, his tragic death did have one important consequence: it obliged the Dutch Government to inquire more closely into the position of the White Raja of Sarawak.

During the six years from 1839 to 1844 Brooke was a private individual with no official backing and no government recognition. It would consequently have been difficult for the Dutch to have framed any charges against him during this period, even supposing they had wished to do so; there was no one to whom they could have addressed their complaints. But when early in 1845 he was appointed British agent in Borneo, and when in August of the same year Admiral Cochrane arrived at Brunei with eight British warships to support him, the Dutch decided, somewhat belatedly, that the Raja of Sarawak had become a menace to the security of their Far Eastern possessions.

At the beginning of December a note was presented to the British Foreign Office by Ambassador Dedel. "It is a matter for regret", it said, "that Mr. Brooke has been placed in the position which he now occupies. In this position, in view of his known prejudice against the Netherlands, he can do much harm". ${ }^{288}$ Lord Aberdeen replied with a vigorous defence of Brooke's character and past proceedings, and suggested that if the Dutch authorities in the East had crossed swords with him, this could only be because they had been interfering with his "legitimate objects and pursuits". It had been found necessary for Her Majesty's Government to appoint an agent in Borneo with the duty of assisting the local rajas to suppress piracy, and $\mathrm{Mr}$. Brooke had been the obvious choice for the post. ${ }^{287}$

284 Dedel to Aberdeen, August 27th, 1844. (C.O. 144/1).

285 Aberdeen to Dedel, November 2nd, 1844. (Buit. Zaken, No. 3133).

286 Dedel to Aberdeen, December 2nd, 1845. (C.O. 144/1).

287 Aberdeen to Dedel, December 10th, 1845. (C.O. 144/1. Kol., 1846, No. 52, Very Secret). 
This explanation did not satisfy the Dutch Government, and Dedel attacked the White Raja again the following March. This time, he said, he was able to offer proof that Brooke was not a fit person to act as British agent in Borneo. The present ruler of Sarawak had shown conclusively during a visit he had paid to Celebes in 1840 that he was anything but favourably disposed towards the Government of the Netherlands. On one occasion he had given "twelve cases of muskets and twenty barrels of gunpowder" to a Bugis chief named Datu Lompulle', who was hostile to the Dutch. ${ }^{288}$

Asked by Lord Aberdeen to give his own version of this event, Brooke was able to justify his conduct completely. At the time of his visit to Celebes, he explained, he was unaware that the Bugis chief in question was hostile to the Dutch Government, and the "three or four muskets, some cloth, and small quantity of gunpowder" which he had given him had been intended solely as a present. So far from trying to stir up revolt in Celebes, he had advised every native chief he met to refrain from hostilities with all European powers, the Netherlands included. ${ }^{289}$

A weakness in the Dutch case against Brooke was that the Netherlands Government had made no formal protest against his actions in Celebes at the time when they occurred. The incidents about which Dedel was instructed to complain in 1845 had apparently not been worth bothering about in 1840 . Nevertheless, it must be admitted that although there had thus far been little either in Brooke's conduct or in his public pronouncements to which the Dutch could legitimately take exception, ${ }^{200}$ they were correct in thinking that he cherished no love for them. There is ample evidence of this in his private correspondence. "I can lay open Borneo", he told Henry Wise at the end of 1841. "If, however, we do not take care, the Dutch will have it, and then farewell hope, for Dutch rule, with respect to natives, is a palsy, and death to British manufactures... Is the English lion for ever to crouch beneath the belly of the Dutch frog ?" ${ }^{201}$ Advising the governor of Sarawak against allowing the Netherlands authorities to gain a footing in Brunei, Brooke gave

288 Dedel to Aberdeen, March 20th, 1846. (C.O. 144/1).

This letter was based on a dispatch from the Governor of Makassar to the Governor-General of April 30th, 1840, No. 181². (Kol., 1841, No. 66, Secret).

289 Brooke to Aberdeen, September 8th, 1846. (F.O. 12/4).

200 Ie. up to 1846 , in which year the first volumes of Brooke's private journals, which did contain a few anti-Dutch sentiments, were published by Captain Keppel.

291 Brooke to Wise, December 10th, 1841. (C.O. 144/1). 
warning that "it was easy to let them come, but... he would find it difficult to get rid of them ever after, and that the most fatal consequences might ensue to his country". ${ }^{292}$ And lastly, describing the evils of Malay piracy to his friend, John Templer, Brooke declared that "those idiots, the Dutch ... encourage this vile traffic because it prevents the natives smuggling, and because it injures the trade of Singapore". ${ }^{293}$

By the end of 1845 it had become clear to the Netherlands Government that, as a result of Raja Brooke's prolonged advocacy, an attempt to found a British colony in Borneo would probably not be long delayed. Three years earlier, the Dutch Minister of the Colonies had viewed this prospect almost with equanimity. ${ }^{294}$ But since then he and his advisers had been receiving reports of greatly increased British naval activity along the north-west coast of the island, of an attempt by a British subject to found a colony in Dutch sovereign territory at Koetei and, finally, of the British Government's grant of virtual protection to the Raja of Sarawak. Consequently, when Dedel made his complaint to Lord Aberdeen about Brooke's appointment as British agent, he also warned Her Majesty's Government that they were prohibited from colonizing Borneo under the terms of the Anglo-Dutch Treaty of 1824. Both contracting parties, he pointed out, had then expressly declared that they would never allow their territorial ambitions in the Indian Archipelago to come into conflict again. "The tendency, the spirit, the principal aim of the Treaty", Dedel urged, had been "to separate the possessions of the two powers in the East Indies for all time to come", ${ }^{295}$

Aberdeen immediately replied that his Government were quite unable to accept any such interpretation of the Treaty of 1824 . It must surely be obvious to the Dutch Government, he said, that in those parts of the Archipelago which the Treaty did not specify as forbidden ground to one or other of the contracting parties, the power of both to establish colonies or make agreements with native princes remained unimpaired. "Had it been intended", he went on, "that the provisions of Article XII of the Treaty, which lays down the limits within which Her Majesty's Government are precluded from forming establishments or concluding treaties with the native chiefs, should be applicable to

202 Brooke to Templer, August 20th, 1839. (Letters, i, p. 68).

293 Brooke to Templer, December 1st, 1841. (Ibid., i, p. 138).

The Dutch were certainly jealous of Singapore, but Brooke's suggestion that they were not playing their full part in the struggle against the pirates was grotesquely inaccurate.

204 See p. 101 above.

2965 Dedel to Aberdeen, December 2nd, 1845. (C.O. 144/1). 
Borneo, that country would assuredly have been named... Her Majesty's Government cannot admit that the expression used in Article XII with reference to any other islands south of the Straits of Singapore can apply to Borneo". 286

To this line of argument, however, Dedel quickly produced an answer. It was certainly true, he said in a note of March 20th the next year, that Borneo had not been mentioned in the Treaty, but this had simply been because that island had not then been a "theatre of common occupation". Other islands where Netherlands sovereignty was exclusively established had not been mentioned either. In 1824 it was only in Sumatra and Singapore that rival agents of the two Governments were disputing "territorial possession or political ascendancy", and the stipulations of the Treaty had therefore been confined to them. The vital point for present consideration was that the agreement of 1824 had been based on an assumption that both parties were sincerely determined to make "a reciprocal renunciation of all territorial community" in the Indies. That they had indeed done so could be proved by reference to the supplementary note which the British plenipotentiaries had addressed to the Government of the Netherlands at the conclusion of the negotiations. On that occasion Canning and Wynn had formally placed on record that the object of the Treaty was "to avoid a collision of interests" between the two countries. ${ }^{207}$

In thus appealing to the spirit rather than to the letter of the Treaty of 1824 , the Dutch Government were trying to make the most of a case which, it was privately admitted in The Hague, was not entirely convincing. During 1845 the Council of Ministers had conducted an investigation into Dutch rights in northern Borneo, and had come to the definite, if reluctant, conclusion that nothing in the Treaty prohibited the British from founding colonies there. "The Treaty of 1824", they reported to the King, "cannot be said to lay down a parallel of latitude to the south of which England may not establish herself ... The idea of a continuous geographical line delineating a southern limit of British influence in the Archipelago is therefore unfounded". ${ }^{288}$

\footnotetext{
206 Aberdeen to Dedel, December 10th, 1845. (Ibid.)

297 Dedel to Aberdeen, March 20th, 1846. (Ibid.)

298 Earlier in the same year Minister Baud had expressed a contrary opinion. (See p. 63 above). Since then, however, he had apparently been won over by the arguments of the Council of Ministers, for the latter concluded their report to the King with the remark: "All this is the unanimous opinion of the Council, and also of the Minister of the Colonies". (Council of Ministers
} 
The result was that, although the Dutch were unwilling to give Great Britain carte blanche in Borneo, Dedel's note of March 1846 did contain one important concession. The Netherlands, he assured Lord Aberdeen, did not believe that it was necessary to exclude British influence from the area entirely. "The cession of Labuan to Great Britain", he said, "and the establishment of a naval station in that island are not susceptible to the same objections by the Netherlands Government, the latter not having extended its sovereignty to that part of Brunei which is situated opposite Labuan, and not expecting that such a step can lead to collisions, at any rate for the time being". ${ }^{299}$ In making this concession, the Dutch were following out the logic of their assertion that one of the chief objects of the 1824 Treaty had been to guard against 'territorial community' in the Indian Archipelago. They obviously could not expect the British Government to agree to this interpretation, and at the same time to refrain from occupying Labuan, which was not part of the mainland of Borneo and was not, in any case, south of Singapore Straits. ${ }^{300}$

Once again, however, the British Foreign Secretary replied that he could not accept the arguments put forward by the Ambassador of the Netherlands. "After the most mature consideration", he declared, "Her Majesty's Government have decided that there is nothing in the Treaty of 1824 to prevent the formation of British settlements in the districts of the Archipelago from which Great Britain is not in terms excluded by the Treaty... Her Majesty's Government have no present intention of availing themselves of this circumstance for the purpose of establishing a colony of the crown, [but] they still cannot allow it for a moment to be supposed that they in any way acknowledge the obligation in no case to take such a step even if rendered expedient or necessary by circumstances the occurrence of which they at present do not anticipate". ${ }^{301}$ In simpler language - Lord Aberdeen's meaning is nearly obliterated by diplomatic circumlocution - the British Government were saying that although they did not at the moment intend to colonize Borneo, they reserved the right to do so.

to the King, November 12th, 1845 , Very Secret, $L^{*} B^{40}$ : 'Diverse stukken over Borneo', Kol., 1845, No. 442, Very Secret).

209 Dedel to Aberdeen, March 20th, 1846. (C.O. 144/1).

300 Minister of the Colonies to the Governor-General, June 10th, 1846. (Kol., 1846, No. 164/Y, Secret).

301 Aberdeen to Dedel, May 4th, 1846. (C.O. 144/1). 
This exchange of letters marks the end of the first round in what ultimately proved to be an extremely tedious contest. For the time being the two Governments agreed to differ on the question of present and future British rights in Borneo. Forty years later Dedel's and Aberdeen's successors were still arguing about what precisely George Canning and Minister Falck had had in mind when they drew up the twelfth article of the Treaty of 1824. 


\section{CHAPTER VI}

\section{THE FOUNDING OF LABUAN}

In the opinion of Raja Brooke, it was not only the Government ot the Netherlands whose reawakening interest in Borneo might endanger the success of his plans. During the 1840's other nations, too, appeared to be developing ambitions in the island. "The French are evidently increasing their squadron in these seas", he wrote in April 1844, "and are desirous of forming a colony, as also are the Belgians and the Prussians". ${ }^{302}$ French warships later bombarded Basilan Island in the Sulu Archipelago in revenge for the murder of two members of the crew of the corvette, Sabine, which had called there to take on water, ${ }^{303}$ but made no attempts at colonization, and Brooke's fears of Belgian and Prussian intervention also turned out to be groundless. But although Great Britain and the Netherlands were the only European powers with an active concern in Borneo there did seem to be a real danger of competition from the United States of America.

In 1831 an American trading vessel, the Friendship, was captured by treachery while lying off Kuala Batu on the West Coast of Sumatra. ${ }^{304}$ After ordering reprisals, ${ }^{305}$ President Andrew Jackson announced that in future more efficient protection must be provided for American sailors and commerce in the Far East, and sent Edmund Roberts to negotiate treaties to that end in Borneo, Siam, and Japan. Ports were to be secured in which American vessels would be able to find refuge and security. Roberts was successful in Siam and began negotiations with Cochin China, but died at Canton before visiting either Borneo or Japan. ${ }^{308}$

In 1836 a group of American business men in China decided to open

302 Brooke to Johnson, April 17th, 1844. (Letters, ii, p. 7).

$303 \mathrm{~J}$. R. Logan, 'The piracy and slave trade of the Indian Archipelago', Journ. Ind. Arch., 1850, pp. 745-6.

304 Ibid., p. 145.

305 A year later U.S.S. Potomac attacked Kuala Batu, setting fire to the town and killing two hundred of the inhabitants.

306 Cf. J. M. Callaghan, American Relations in the Pacific and the Far East, pp. 48 and 73-4. 
regular commercial intercourse with Borneo. They hoped to obtain pepper, coffee, and any other "surplus products" which might be available in exchange for dollars, iron, and cloth. ${ }^{307}$ They chartered a brig, the Himmaleh, which arrived at Brunei the following year and sold its cargo at a good profit, but the experiment was not repeated. A few years later the 'United States Exploring Expedition' also visited Borneo under Admiral Charles Wilkes, who reported favourably to the American Government on the island's commercial possibilities. ${ }^{308}$

Finally, early in 1845 the U.S.S. Constitution called at Brunei to offer the Sultan immediate protection and a commercial treaty in return for the exclusive right to work all coal deposits in the Sultanate. Her captain announced that he came from "the Sultan of America... to bring cordial greetings, assurances of friendship, and the desire for a more intimate intercourse". ${ }^{309}$ Because of Brunei's existing agreements with Great Britain, Raja Muda Hassim postponed a decision on this American proposal until he had consulted Brooke. "If the British Government are unwilling to afford us assistance", he told the White Raja, "we must then beg our friend to move that the existing arrangements be cancelled, so that we may be in a situation to solicit aid in another quarter". ${ }^{310}$ Recounting this incident to Lord Aberdeen, Brooke pointed out that unless Great Britain soon showed by positive action that she intended to fulfil her obligations to Brunei, there was more than a chance that the Sultan and his advisers would seek United States protection. The prolonged delay had already instilled into the native mind "a doubt touching the power of Her Majesty's Government", and the visit of an American warship had done much to strengthen this impression. ${ }^{311}$

Meanwhile, Captain Bethune had completed his investigation into possible sites for a British naval station, and in October 1845 he forwarded his long-awaited report to the Admiralty. Brooke had been working closely with Bethune, and was hopeful that on receipt of this report the British Government would at last come to some definite

307 'Instructions from the Owners to Captain Fraser of the Himmaleh', November 26th, 1836. (Quoted in Tradescant Lay, op. cit., pp. viii-ix).

308 C. Wilkes, Narrative of the United States Exploring Expedition (1838-1842), Vol. v, p. 360.

309 Report of Lieutenant W. C. Chaplin, U.S.N., April 9th, 1845. (Copy in Kol., December 3rd, 1845, L* A, No. 2).

310 Hassim and Pěngeran Badru'd-din to Brooke, 1845 (n.d.). (P.P., 1852-3, LXI, p. 307).

311 Brooke to Aberdeen, June 28th, 1845. (F.O. 12/3). 
decision on their future policy in Borneo. But in this he was disappointed. The effect of Bethune's report was to throw the whole question into the melting-pot again, for it proposed that a naval station should be established not at Labuan, but at Balambangan.

The island of Balambangan, situated off the northern tip of Borneo, was well placed to act as an advanced base against the Lanun and Balanini pirates who infested the area, and also to command the strategically important junction of the Sulu and South China Seas. The East India Company had attempted to found trading settlements there on two separate occasions, once in 1773 and again in 1803. Both had been total failures, but the fact of their existence had given Great Britain a title to the island, and Bethune's proposal was that this title should now be enforced. The main "military and commercial post" for the area, in his view, should be at Balambangan, while Labuan, which was "too valuable, looking to the prospective advantages of the case, to be given up", should be acquired by purchase from the Sultan of Brunei. ${ }^{312}$

Not only did this report confuse further a situation that was complicated enough already, but it also chanced to arrive in England at a particularly unsuitable time. During December 1845 and January 1846 a minor reshuffle occurred in Sir Robert Peel's Cabinet. The Earl of Ellenborough replaced Lord Haddington as First Lord of the Admiralty, and W. E. Gladstone succeeded Lord Stanley at the Colonial Office. Haddington had been the most receptive of Peel's cabinet ministers to Raja Brooke's ideas, and his departure from the Admiralty meant that much of Henry Wise's skilful propaganda campaign on behalf of a British colony in Borneo was now wasted. When, for example Wise sent a complete set of Borneo Papers to Lord Ellenborough and asked for the honour of an interview, the new First Lord replied that before granting such a request he would need time to study the 'book' which had been presented to him, and that he could not say at present how soon he would be able to do so. ${ }^{313}$

In the early part of 1846 scant attention to a comparatively unimportant question like Labuan was to be expected from either Peel or Gladstone. The Prime Minister was busy preparing for his final battle with the House of Commons over the repeal of the Corn Laws, ${ }^{314}$ and the newly-appointed Colonial Secretary was more than fully

312 Bethune to the Admiralty, October 1st, 1845.

s13 H. S. Law to Wise, February 28th, 1846. (Borneo Papers, p. 85).

314 E. L. Woodward, The Age of Reform 1815-1870, p. 118. 
occupied in attempting to solve more urgent problems in Canada, the West Indies, and New Zealand. ${ }^{315}$ The Earl of Aberdeen, the only other minister whose department was directly concerned, had never been enthusiastic about the plan to form even a naval station in Borneo, and had agreed to it only after Stanley withdrew Colonial Office opposition at the end of 1844 . As month after month went by with no sign from the British Government that they intended to take any further action, Brooke's friends in England began to fear that his great plans for Borneo were about to collapse. But suddenly in the middle of May the outlook changed, when reports arrived of a wholesale massacre at Brunei.

When the Sultan of Brunei agreed to allow British naval forces to suppress piracy in his dominions, he inadvertently signed away a large part of his private income, because an important share of the Brunei state revenues was derived from the slave trade, and this in turn depended for its existence almost entirely on the proceeds of piracy. It was therefore a simple matter for Haji Saman, the leader of the opposition party at the Brunei court, to persuade His Highness that a continuance of friendly relations with Great Britain was certain to lead in the end to financial ruin.

In addition to appealing in this way to the Sultan's avarice, Haji Saman also cunningly played upon his master's jealously of Raja Muda Hassim. His Highness had secretly been greatly mortified when Hassim was reinstated by Brooke and Belcher in October 1844 as Raja Muda, since he had been hoping to secure the succession for his son. By the use of tactics such as these and by flattering the Sultan and listening to his countless grievances, Haji Saman eventually persuaded him to order the assassination of the Raja Muda and all the most influential members of the pro-British party at Brunei on the grounds that they were traitors to the throne.

More than two months went by before any news of this outrageous piece of cruelty reached the outside world, and even then Raja Brooke learnt of the massacre of his friends only by accident. In the middle of March 1846 H.M.S. Hazard (Commander Egerton) ran aground on Muara Island at the southern entrance of Brunei Bay. While she was waiting for a tide to lift her clear, a canoe darted out from the shore bearing a native slave-boy named Japar, who had once been owned by

${ }^{315}$ See W. P. Morrell, British Colonial Policy in the Age of Peel and Russell, pp. $68-9,126$, and $160-2$. 
Pĕngeran Badru'd-din, a younger brother of Raja Muda Hassim. Japar informed the captain of the Hazard that Hassim and no less than twelve other members of the Royal Family of Brunei were dead; that most of them had been murdered outright, although the Raja Muda and Japar's master, Badru'd-din, had committed suicide rather than fall into the Sultan's clutches alive; that forts were even now being constructed to defend the city; and that the Sultan, who had sworn that he would hold no more intercourse with Europeans, was openly defying the British Navy to come and do its worst. Japar himself had been obliged to remain in hiding for two months, and had only just been able to escape; he now wished to carry out his master's dying command that Tuan Brooke must be advised of the fate of his faithful Brunei allies. ${ }^{318}$

The Hazard made all speed to Kuching and on March 30th Japar repeated his story to Brooke. The White Raja exploded with anger. "I can repair the loss in part", he wrote to Wise on April 1st, "but depose the Sultan, destroy Brunei, reinstate Muda Hassim's family are indispensable considerations... I am at war with this traitor and murderer, and such is my grief and rage that I would plunge a knife into his body if he was within arms' reach". ${ }^{317}$ To Brooke the Brunei massacre was not only a blow to his personal prestige along the coast, but also a gross insult to the British Government. "I cannot but believe", he declared in a letter to Lord Aberdeen, "that a strong case exists for the protection of the survivors of Muda Hassim's family, and for the punishment of the offender, who, abandoning all good faith towards Her Majesty's Government, has, by an act of almost unheard-of treachery, butchered his nearest relations on account of their fidelity to their engagements and, in conjunction with the British authorities, having pursued the necessary measures for the suppression of piracy". ${ }^{318}$ But Aberdeen was far away in England, and the situation demanded action at once. Without waiting for instructions from the Foreign Office, Brooke appealed direct to his friend, Rear-Admiral Sir Thomas Cochrane, the naval Commander-in-Chief of the Far Eastern Station. "I feel convinced", he told Cochrane, "you will act against this atrocious Sultan, and inflict upon him the punishment he has sought at your hands". 318

316 'Deposition of the native Tapper [Japar]'. (P.P., 1852, XXXI, p. 422).

317 Brooke to Wise, April 1st, 1846. (F.O. 12/4).

318 Brooke to Aberdeen, April 1st, 1846. (P.P., 1852, XXXI, p. 422).

310 Brooke to Cochrane, April 1st, 1846. (Ibid., p. 423). 
Cochrane was not the man to turn a deaf ear to an appeal such as this. When he received Brooke's letter he was so impressed with the urgency of the situation that he also decided to act without waiting for definite orders, and on June 18th set sail for Borneo from Singapore with the largest force he could muster. Picking up Brooke at Kuching, the Admiral proceeded up the coast to Brunei in his 74-gun flagship, Agincourt, supported by H.M. Ships Iris, Hazard, Ringdove, and Royalist, H.M. Steamer Spiteful, and H.E.I.C.S. Phlegethon. ${ }^{\mathbf{3 2 0}}$ The forts guarding the entrance to Brunei River were quickly reduced, and on July 8th the squadron swept upstream to the capital. After a heavy bombardment of the defences, British landing-parties under Captain Mundy of the Iris entered the town unopposed, and discovered that the Sultan and his court had already fled into the interior. ${ }^{321}$ Brooke and Cochrane immediately set about reorganizing the government of the Sultanate. Two of the very few pro-British nobles who had survived the massacre were placed in charge of the state, and Cochrane issued a proclamation to the effect that "if the Sultan would return and govern his people justly, abstain from acts of piracy and keep his agreement with the British Government, hostilities would cease, but on the other hand if the same atrocious system was again carried on when the ships left the coast, the admiral would return speedily and burn the city to the ground". ${ }^{222}$ The Sultan's morale, however, had not unnaturally been shattered by his recent experience, and for the time being nothing would persuade him to leave the security of his jungle hiding-place.

Realizing that in these circumstances there was nothing more that he or his warships could achieve by waiting at Brunei, Cochrane reembarked his force and moved the whole squadron up the coast to Tempasuk. After chastising some Lanun pirate settlements there and at Pandasan, he set sail for China with the main body of his fleet, leaving Captain Mundy with the Iris, Hazard, and Phlegethon to attend to affairs in Borneo. Mundy's orders were to revisit Brunei, make a settlement with the Sultan if possible, and then extirpate Lanun piracy along the whole of the north-west coast. ${ }^{323}$

As Mundy made his way south to Brunei, a friendly prahu hailed him to pass on the news that the Sultan's sometime adviser and evil genius,

320 Mundy, op. cit., Vol. ii, p. 116. H.M.S. Daedalus and H.E.I.C.S. Pluto were also ordered to Borneo, but arrived too late to take part in the action.

321 Cochrane to the Admiralty, July 9th, 1846. (P.P., 1852-3, LXI, p. 257).

${ }^{322}$ Mundy, op. cit., Vol. ii, p. 175.

823 Ibid., p. 208. 
Haji Saman, was lurking in Membakut River, a small stream flowing into Kimanis Bay. An armed party was sent up the river to capture him, but the Haji proved as elusive as his master, and Mundy's men had to be content with destroying a few fortifications and gun positions. After this episode Brooke continued on his way to Brunei in the Phlegethon, while Mundy went back to Kimanis to assure the local inhabitants that he would protect them should Haji Saman dare to show his face in the area again.

The Phlegethon and the Iris met by chance off Labuan on August 24th, and Brooke reported that his mission to Brunei had been completely successful. The Sultan had at last been induced to return to his palace, had humbly asked pardon for his past follies, and had re-ratified all his former engagements. ${ }^{324}$ Brunei politics were now once again back to normal, and would remain so provided British warships continued to patrol the coast. But although the course of local affairs was again running in his favour, the question which most concerned the White Raja was, would the Sultan of Brunei's rebellion have any effect on the slow-moving authorities in London, and make them agree at last to the establishment of a British settlement in northern Borneo?

Towards the end of May 1846 the British Foreign Office received a strongly-worded memorial from the Glasgow Chamber of Commerce. The merchant community of Glasgow, asserted this document, were unanimously of opinion that a much more vigorous British policy was needed in the Eastern Seas. A naval station should be established immediately between Singapore and China to protect British trade; the island of Labuan appeared to be ideally suited for this purpose. ${ }^{325}$ Two days later a similar memorial arrived at the Foreign Office from the Glasgow East India Association, complaining that the Dutch had taken possession of $\mathrm{Bali}^{328}$ an island which had long been regarded as "the chief granary for Singapore". The loss of Bali's rice supplies, said the Association, would be a severe blow to British trade in the East. How much longer were the Dutch to be permittted to expand their influence in the Indian Archipelago in this way? A firm stand must be taken at once against further encroachments by the Government of the Netherlands Indies. ${ }^{327}$

324 Ibid., pp. 234-6.

325 Glasgow Chamber of Commerce to Aberdeen, May 21st, 1846. (F.O. 12/4).

326 The 'First Bali Expedition', as it is called, took place early in 1846. It achieved no decisive results, and the Dutch sent a second in 1848 and a third in 1849. (Cf. Colenbrander, op. cit., Deel iii, pp. 175-6).

327 Glasgow East India Association to Aberdeen, May 23rd, 1846. (F.O. 12/4). 
These two memorials arrived at the Foreign Office simultaneously with the first reports to reach England of the massacre of the proBritish party at Brunei. When the news of this disaster became public property, more letters and memorials began pouring into the Foreign Office and other Government Departments from the Chambers of Commerce and East India Associations of London, Manchester, and Liverpool, as well as several fresh entreaties from Glasgow. All of them complained of past Government apathy, pointed out the dangers of the present situation, and demanded that the Sultan of Brunei's offer of Labuan be accepted by Great Britain without delay. ${ }^{328}$

On receipt of the news from Brunei, however, the Foreign Office had already taken action on their own account. On May 26th they inquired from the Admiralty what was being done about a naval station or settlement on the Borneo coast. ${ }^{329}$ The Admiralty replied that at the moment nothing was being done. The Lords Commissioners could not proceed in such a matter on their own initiative. It was a question for the Colonial Office - indeed, for the whole Government. ${ }^{330}$ The Foreign Office retorted that this was a surprising change of attitude on the Admiralty's part; had it not been agreed in 1844 that a naval station was "indispensably necessary" in Borneo? Had not Captain Bethune been sent to the Far East especially to select a site for one? The Foreign Office considered that they were "justified in thinking that the Admiralty would take measures to secure the objects contemplated by Her Majesty's Government". ${ }^{331}$

Faced with the suggestion that they were trying to evade a responsibility that properly belonged to them, the Admiralty took refuge in precedent. When the decision had been taken to occupy Port Essington, ${ }^{332}$ they pointed out, the necessary instructions had been issued by the Colonial Office, although the actual work of establishing the settlement had been done by the Royal Navy. If Labuan was now to be occupied, a similar procedure should be followed. "We do not consider ourselves justified", they said, "in annexing territory to the British Crown without the express direction of a Secretary of State".

328 Many of these documents used almost identical language. They may possibly all have been instigated by Henry Wise. (The originals are in F.O. 12/4).

329 Foreign Office to the Admiralty, May 26th, 1846. (Ibid.)

330 Admiralty to the Foreign Office, May 27th, 1846. (Ibid.)

331 Foreign Office to the Admiralty, May 30th, 1846. (Ibid.)

832 An abortive trading settlement on Cobourg Peninsula on the north coast of Atstralia, founded in 1838. 
In any case, Captain Bethune's report had recommended Balambangan in preference to Labuan as the most suitable site for a base against the pirates, although in the Admiralty's own opinion a "moveable force" would be better than either. If the proposed naval station were planted down in the very middle of the pirate strongholds, the enemy would be able to spy on the movements of British warships as they were assembling for the attack. A mobile striking force, on the other hand, with no fixed base nearer than Singapore, could pounce on the pirates without warning. ${ }^{333}$

The Foreign Office answered shortly that they considered "the expediency of establishing a naval station to protect trade and suppress piracy as already settled by what passed in October 1844". They could not agree that Balambangan was preferable to Labuan. The British Government had a firm title to the latter, and had already told the Dutch that it would be occupied. ${ }^{334}$ But the Admiralty's obvious reluctance to take any action at all in the matter convinced Lord Aberdeen and his staff that nothing was to be gained by continuing an unprofitable argument, and they turned for assistance to the Colonial Office.

Mr. Secretary Gladstone, however, was just as much against a settlement in Borneo as the Lords Commissioners of the Admiralty. He pointed out in a note to Lord Aberdeen that it was "no part of the policy of Her Majesty's Government to establish any colony on the coast of Borneo". All that had ever been suggested was "a naval station and harbour of refuge" - obviously a task for the Admiralty. Even this more limited plan had not yet been finally agreed to, as the Foreign Office appeared to assume; the Treasury, for example, had not yet given their formal assent. In any case, there was little practical difference between colonies and naval stations so far as the problems of administration were concerned. The two types of settlement always tended to coalesce. "We may prohibit the use of land or the erection of houses upon it", said Gladstone by way of illustration, "but how can we prevent or punish those who may be inclined to disobey the prohibition?" Once a permanent establishment of any kind had been set up, laws and regulations always had to be provided, labour forces

s33 Admiralty to the Foreign Office, June 5th, 1846. (Ibid.) The Admiralty's reluctance to take the initiative with regard to Labuan may have been due to the difficulties they had experienced in the Falkland Islands a short time before. In 1832 the Royal Navy received orders to annex these islands, but was not relieved of administrative responsibility for them until 1843.

234 Foreign Office to the Admiralty, June 8th, 1846. (Ibid.) 
supplied, expensive administrative machinery instituted. In an area like Borneo there was the additional difficulty of a mixed population, which would inevitably complicate the problems of local government. From a more general point of view, moreover, it was clear that the British Empire already had more responsibilities than it could carry. "The multiplication of colonies at the other end of the world", Gladstone declared, "must at all times be a matter for serious consideration; but especially at a time when we have already land almost infinite to defend that we cannot occupy, people to reduce to order whom we have not been able to keep in friendly relations, and questions in so many different departments of government to manage". For all these reasons, he and his advisers had decided that they could take no action until further thought had been given to the matter by the Government as a whole. Almost apologetically, Gladstone explained to Lord Aberdeen that he had felt it would be better to put his objections in the form of a private memorandum rather than in an official answer, because "the battle seems to have been hot between you and the Admiralty". 335

Towards the end of June the Foreign Office staff compiled a comprehensive history of the Labuan question to date, and forwarded it to Gladstone in an attempt to make him reconsider his decision. It was now too late, said the Foreign Office, for the Colonial Secretary to dissociate himself from the Borneo proposals. The relevant documents on Labuan and related matters had long been in the possession of the Colonial Office, who ought to have put forward their objections earlier, instead of allowing others to pledge themselves to a course which apparently was "diametrically opposed to the views of the Department whose province it was to carry the same into effect". There were at least six good reasons why the Labuan plan could not be abandoned at this stage. First, the Government could not now tell the parties concerned that a settlement in Borneo had never been contemplated. Secondly, the Dutch had been informed that the island definitely would be occupied. Thirdly, the merchant community were pressing for more vigorous action. Fourthly, "prospects of support and protection" had been held out to British subjects. Fifthly, it was already being claimed by some (the Manchester Chamber of Commerce, for example) that the Brunei massacre was the result of official negligence. And, lastly, if Raja Brooke were killed, his death would inevitably be blamed on Her Majesty's Government. The threat of competition from other

335 Minute by W. E. Gladstone of June 18th, 1846. (C.O. 144/1). Quotations from this minute appear in Henry L. Hall, The Colonial Office, pp. 174-5. 
powers had also to be taken into account. The Americans were trying to obtain a footing at Brunei, and the French at Sulu. As for the Dutch, "the archives of the Foreign Office are crowded with representations of the injurious effects to British interests arising from the extension of Dutch influence and dominion in the Eastern Seas". 336

At this point, however, inter-departmental discussions on Labuan came to a sudden halt. On the very day that the Foreign Office's appeal to Gladstone was signed, June 25th, Sir Robert Peel's Government was defeated in the House of Commons over a coercion bill for Ireland. ${ }^{337}$ Peel resigned four days later, and early in July Lord John Russell accepted the Queen's invitation to become the new Prime Minister. Russell appointed Earl Grey as his Colonial Secretary and Lord Palmerston as his Secretary of State for Foreign Affairs. Both appointments were of great significance for the future development of British policy in Borneo.

The first member of the new Government to look into the Labuan question was Benjamin Hawes, Parliamentary Under-Secretary for the Colonies. "We have now to decide", he told his chief, Earl Grey, "whether we abide by Mr. Gladstone's position or by Lord Aberdeen's". Hawes studied the arguments assembled by the Foreign Office, and became convinced that the occupation of Labuan was desirable. The island, he believed, was well suited as a settlement for all "political, moral, and commercial purposes". With encouragement it could become a valuable emporium for trade similar to Singapore. ${ }^{\mathbf{3 3 8}}$

But Sir James Stephen, the Permanent Under-Secretary at the Colonial Office, remained unconvinced. He warned Hawes of the danger that the addition of Labuan to the British Empire might be the first step in a ruinous policy of expansion. He referred to the "territorial accretions" (as he called them) which would "infallibly be made to it on the mainland of Borneo". If a colony were really necessary, then by far the wisest plan would be to persuade the East India Company to accept responsibility for founding and maintaining it. "The Company", said Stephen with feeling, "act with all the unembarrassed simplicity of movement which belongs to absolute, not to say despotic, power". It was true that they were "notoriously inefficient", and that, in consequence, a settlement in Borneo under their auspices would cost more than one supervised by the Colonial Office, but they enjoyed the

$3 s 8$ Foreign Office Minute of June 25th, 1846. (F.O. 12/4).

857 Woodward, op. cit., p. 118.

238 Minute by B. Hawes (n.d.). (C.O. 144/1). 
supreme advantage of not having to submit annual estimates to the House of Commons. ${ }^{339}$

Stephen's reference to 'territorial accretions' raises the interesting question of why the British Government never seriously considered Sarawak as a possible site for the proposed settlement. Brooke himself pressed unceasingly for acceptance of the offer he had made in 1842 . Although he welcomed the decision to turn Labuan into a naval station, he always thought it a poor substitute for his own fine kingdom at Sarawak. "It is a very short-sighted view", he wrote, "which ties us up in small islands". ${ }^{40}$

There were three main reasons why the White Raja's offer of Sarawak was not accepted. In the first place, Labuan was clearly preferable to Sarawak as a naval station. Belcher, after inspecting the harbour facilities at Kuching on behalf of the Admiralty, reported that they were inadequate. ${ }^{341}$ Labuan, on the other hand, as Brooke himself admitted, possessed an excellent harbour by comparison, ${ }^{342}$ and many other advantages as well. Brooke recorded the following description of it in his journal: "An island of about fifty feet high; ${ }^{343}$ twenty-five miles in circumference; woody; timber good; water from wells and a few small streams, which, after a drought, are dry; natives say, water never fails. Anchorage good for the climate; well protected from the N.E. ... situation of contemplated town low; climate healthy ... The island of Labuan, for the purposes of refuge for shipwrecked vessels, of a windward post relative to China, for the suppression of piracy, and the extension of our trade, is well suited". ${ }^{344}$

Secondly, the fact that Labuan was an island increased rather than detracted from its value in the eyes of the British Government. The troubles caused by the Maoris of New Zealand after they had agreed to accept British sovereignty in accordance with the Treaty of Waitangi (1840) were fresh in mind. The Government were afraid that the same story would be repeated in Borneo if they set up an establishment on the mainland there. The fear of becoming entangled in domestic squabbles acted as a powerful deterrent to Stanley, Gladstone, and Aberdeen, and may well have been the chief reason why John Craw-

339 Stephen to Hawes (n.d.). (C.O. 144/1).

340 Brooke to Templer, December 22nd, 1843. (Letters, i. p. 309).

341 Belcher, op. cit., Vol. i, p. 33.

342 'Labuan' is Malay for 'harbour' or 'anchorage'.

343 The highest point on Labuan is, in fact, 336 feet high.

344 Dido, ii, pp. 167-8. 
furd refused to recommend Sarawak as a suitable place for a British settlement when his advice on the matter was sought in $1844 .^{\mathbf{3 4 5}}$

Finally, it must be remembered that 'island-taking' was in line with the strategic policy of the day. Recent examples were the Falkland Islands and Hong Kong. Islands could be protected by sea-power, without the need of expensive military garrisons. Moreover, in view of Labuan's possibilities as an emporium for trade, there were some who thought that an optimistic parallel could be drawn with that most successful of island entrepôts, Singapore.

Labuan was therefore selected in preference to Sarawak, and by the time the new Government took office there also was general agreement that, whether the Borneo settlement was to be a Crown Colony or only a naval station, its administration, as Gladstone had pointed out, would ultimately have to be undertaken by the Colonial Office. Everything now depended on the attitude adopted by Earl Grey. Conflicting advice had been given him by his two Under-Secretaries, Hawes and Stephen, and he had to decide which of their recommendations he would accept.

It did not take Grey long to make up his mind. Halfway through July 1846 he set the seal of Colonial Office approval on the plan to create a British colony in Borneo. He later explained to Lord John Russell that on taking office he had been greatly impressed by the memorials which had been received from Manchester, London, and Glasgow, "earnestly praying" that the island would be occupied. Pressure from the commercial world seems to have been the principal reason for his decision. ${ }^{346}$ Stephen's suggestion that responsibility should be shifted to the East India Company was disregarded by Grey entirely. ${ }^{347}$

The necessary orders for the foundation of the colony were issued to the Admiralty on July 24th by Lord Palmerston. As well as providing for the occupation of Labuan, these instructions signified that it was the Queen's command that ships of the Royal Navy stationed in the Far East were to give "proper and efficient protection" to Mr. James Brooke, and were also to maintain "a sufficient force on the coast of

845 See Crawfurd's evidence before the Select Committee on Army and Ordnance Expenditure, July 5th, 1850. (P.P., 1850, X, pp. 718-19).

348 Earl Grey, The Colonial Policy of Lord John Russell's Administration, Vol. ii, pp. 265-6, and Speech in the House of Lords, April 18th, 1850 (Hansard, Ser. iii, Vol. 110, Col. 490).

347 See Grey's evidence before the Select Committee on Army and Ordnance Expenditure, June 14th, 1850. (P.P., 1850, X, pp. 652-3). 
Borneo for the purpose of protecting British interests". ${ }^{348}$ The White Raja's five year long battle for recognition was over.

Meanwhile Admiral Cochrane's attack on Brunei had been carried out, although Palmerston was not aware of this when he issued the order to occupy Labuan. At the end of August Captain Mundy, who had been placed in command of all Royal Naval vessels on the coast of Borneo after Cochrane's departure for China, tried to re-open negotiations with the Sultan of Brunei. The mere rumour of the approach of a British warship, however, was sufficient to send the Sultan scurrying off into the jungle again. Mundy made a second attempt three weeks later, and this time His Highness summoned up the courage to remain at the capital to receive him. Gunboats from H.M.S. Iris were anchored opposite the palace, and a marine guard lined the terrace leading to the royal audience chamber. "The Sultan received me at the entrance of the audience-hall", Mundy wrote later, "and the marines, who were drawn up in a position directly enfilading the divan, presented arms as I stepped over the threshold, and made their pieces tell well together. I observed the old monarch tremble in his slippers". The Sultan readily gave his visitor an assurance that he would submit to any terms which Admiral Cochrane or Raja Brooke might be pleased to dictate. 348

After this episode Mundy returned in the Iris to Singapore, and waited there in the hope that orders would soon be received from the Commander-in-Chief in connection with Labuan. In this he was not disappointed, for on November 25th dispatches arrived from Hong Kong directing him to go at once to Brunei, secure a formal deed of cession from the Sultan, and then take possession of Labuan in Her Majesty's name. On the way back to Brunei he called at Kuching to talk the matter over with Raja Brooke, and both men agreed that the Sultan would almost certainly demand a sum of money in exchange for the deed of cession. Mundy's difficulty was that financial arrangements regarding Labuan had been mentioned neither in the 1844 agreement nor in the orders he had received from Admiral Cochrane. Brooke was satisfied, however, that a little firmness would soon bring the Sultan to heel. ${ }^{350}$

On December 15th Mundy brought the Iris to anchor in Brunei

348 Palmerston to the Admiralty, July 24th, 1846. (C.O. 144/1).

349 Mundy, op. cit., Vol. ii, pp. 262 and 264.

850 Ibid., p. 289. 
River. The following morning he sent his first Lieutenant, Heath, to the capital with letters for Pengeran Mumin, the Chief Minister at the Sultan's court. The contents of these letters, according to Mundy's own account, were as follows: "They gave a sketch of my instructions, but at the same time set forth the indignation which was felt by the English Government at the Sultan having fired at the Queen's flag, ${ }^{351}$ and that it would greatly depend upon the conduct of his Highness and the pěngerans ... whether or not pacific relations be renewed". The Captain of the Iris believed that the plan he was adopting of "keeping up the prospect of another visit from the admiral, the English raja, and the fleet, would be the best antidote against violent opposition from the ill-disposed perngerans, and the piratical party in general". ${ }^{352}$ In other words, the Sultan must cede Labuan, or run the risk of being chased into the jungle again!

When Mundy presented himself at the palace two days later, all his demands were met. The Sultan and perngerans held out for compensation, as expected, but by a judicious rattling of the sabre Mundy eventually obtained the royal signature. As he himself put it, "The boats in line of battle in front of the palace, and the marines with fixed bayonets on the threshold of the audience hall, though a picturesque group, were by no means calculated to encourage any act of violence". ${ }^{353}$

The treaty to which the Sultan and Captain Mundy set their hands on December 18th, 1846, was brief and to the point. It contained only three articles:

1. Peace, friendship, and good understanding shall subsist for ever between Her Majesty the Queen of Great Britain and Ireland, and His Highness the Sultan of Borneo Proper, and their respective Heirs and Successors.

2. His Highness the Sultan hereby cedes in full sovereignty and property to Her Majesty the Queen of Great Britain and Ireland, Her Heirs and Successors for ever, the Island of Labuan and its dependencies, the Islets adjacent thereto.

3. The Government of Her Majesty the Queen of Great Britain and Ireland hereby engages, in consideration of the cession above specified, to use its best endeavours to suppress Piracy, and to protect

351 A reference to Admiral Cochrane's attack on Brunei of the previous July, in which affray the Sultan's guns had, in fact, fired first.

352 Ibid., pp. 293-4.

253 Ibid., p. 298. Mundy to Cochrane, January 12th, 1847. (C.O. 144/2). 
lawful commerce, and the Sultan of Borneo, and his ministers, promise to afford every assistance to the British authorities. ${ }^{354}$

Mundy presented the Sultan with a silver-mounted telescope, embarked his marines, and sailed the Iris across Brunei Bay to Labuan. There, at twelve noon on December 24th, in the presence of the assembled perngerans of Brunei - but not of their master, who had excused himself from the ceremony on the ground that a journey on the open sea always made him seasick - the island of Labuan finally became part of the British Empire. ${ }^{355}$

Although by the end of 1846 Raja Brooke had good reason to be satisfied with the development of his Bornean policy, his own personal position was still a matter of considerable difficulty and anxiety to him. The status of Confidential Agent granted him by Lord Aberdeen had been official recognition of a kind, but his services in that capacity were unpaid. Aberdeen had in fact been content to take advantage of Brooke's prestige in order to promote British commercial and strategic interests in Borneo, and at the same time had refused to give him a regular diplomatic appointment lest Great Britain should become too deeply involved in the island's domestic politics. Brooke himself never made any attempt to capitalize on his unique position, and might have been willing to carry on indefinitely as 'honorary' British agent had his private finances been able to bear the strain. But year by year the fortune which he had inherited from his father was slowly being eaten away by the expenses of the day to day administration of Sarawak. It was therefore fortunate for Brooke that the new Foreign Secretary did not share his predecessor's nervousness. Early in 1847 Palmerston appointed him 'Commissioner and Consul-General to the Sultan and Independent Chiefs of Borneo' at a salary of $£ 500$ a year. ${ }^{356}$

In May of the same year, on the Foreign Secretary's instructions, ${ }^{357}$

${ }^{854}$ F.O. $93 / 16(1)$.

${ }^{355}$ Mundy, op. cit., Vol ii, pp. 305-7. See also F. E. Forbes, Five Years in China ..., pp. 287-8, and Rutter, op. cit., pp. 199-212.

356 The appointment was back-dated to February 24th. (Foreign Office to Wise, March 16th, 1847: C.O. 144/2).

357 Foreign Office to Brooke, January 25th, 1847. (F.O. 12/5). These instructions also contained a suggestion that the Sultan should be persuaded to cede "an additional district extending to a certain distance inland from the coast", the object being to prevent interference with Labuan. Nothing came of this proposal, however; it may have been inspired by the analogy of Province Wellesley. 
Brooke went to Brunei to negotiate a new treaty with the Sultan, designed to secure permanent British control over the commerce of the north-west coast. In addition to laying down certain conditions of free trade and free access for British merchant vessels to Brunei ports, this treaty forbade the Sultan to make "any cession of an island or of any settlement on the mainland in any part of his dominions to any other nation, or to the subjects or citizens thereof, without the consent of Her Britannic Majesty". ${ }^{358}$ If the White Raja had been able to foresee the trouble and irritation this seemingly innocuous article would later cause Sarawak, he might not have been so ready to obtain the Sultan's signature to it!

Soon after completing his mission to Brunei, Brooke set sail from Borneo for his first visit to England in nine years. In 1838 he had left it as an unknown adventurer. He returned a national hero. The publication of his journals by Captain Keppel in 1846 had familiarized the fashionable world with his exploits, and he was fêted and lionized wherever he went. Government Departments sought his advice on the problems of the Far East, and he received a knighthood from Queen Victoria for the great services he had rendered to his country. When the time came to appoint a Governor for the new colony of Labuan, Grey and Palmerston had no need to look farther than the man who had already shown such outstanding ability in dealing with the inhabitants of the Bornean coasts. On January 22nd, 1848, Brooke was created Governor and Commander-in-Chief of Labuan at the princely salary of $£ 2,000$ a year. ${ }^{350} \mathrm{He}$ returned to the East aboard H.M.S. Maeander, a vessel specially detailed by the Admiralty for the purpose, and commanded by his old friend and champion, Captain Keppel, and entered upon his new duties the following September. ${ }^{360}$

In many ways, the year 1848 may be taken as the apex of Sir James Brooke's career. His position as Raja of Sarawak was secure as never before, and he had a positive assurance from the British Foreign Secretary of continued naval support for his independent kingdom. The assassination of Raja Muda Hassim had incidentally provided him with

358 Treaty of May 27th, 1847. (F.O. 93/16 (2). Copy in Maxwell and Gibson, op. cit., pp. 143-7).

350 Grey to Brooke, January 22nd, 1848. (P.P., 1847-8, XLII, pp. 251-2).

The Governor of the Falkland Islands, for example, was receiving $£ 800$ a year at this time, as also was the Governor of Western Australia. Even the Governor of New Zealand received only $£ 2,500$ a year. (See P.P., 1847-8, XL, pp. 393-9).

300 Maeander, i, p. 32. 
a pretext for cutting the last formal links which bound him to the treacherous Sultan of Brunei, and after 1846 the annual tribute of $\$ 2,500$ which he had been paying for four years was discontinued. Admiral Cochrane's naval operations of the same year raised the White Raja higher than ever in the esteem of the local population. The Dyaks of the interior, for example, were staggered to hear of the fall of Brunei, which they had always regarded as the greatest power on earth. ${ }^{361}$ Sarawak itself was steadily growing in importance and prosperity. Kuching had now become a substantial town of 45,000 inhabitants, ${ }^{362}$ and Brooke estimated the total value of its exports at between two hundred and two hundred and fifty thousand dollars a year. ${ }^{\mathbf{3 6 3}}$

The White Raja's very success, however, contained within itself the seeds of future disaster. The glare of publicity which greeted him on his return to England also illuminated the methods by which he had achieved his present extraordinary position. It was soon being whispered by some that these methods were not altogether creditable, either to their author or to those who had given him protection and support. Particular criticism was directed at his effective but admittedly ruthless treatment of the Borneo pirates. Were the expeditions of Keppel, Cochrane, and others, it was asked, really a necessary part of the Royal Navy's duty to protect British commerce in the Far East? Or were they the outcome of an unscrupulous desire on the part of this so-called White Raja to subject innocent savages to his will? As these attacks grew in strength and virulence, Brooke and his friends were shocked to discover that they were largely inspired by the man who had once been Sarawak's greatest protagonist, Brooke's London agent, Henry Wise.

361 Spenser St. John, Rajah Brooke, p. 80.

${ }^{362}$ Maeander, ii. p. 2.

303 Brooke to Templer, March 5th, 1850. (Letters, ii, p. 276). Accurate figures of the export and import trade of Sarawak are not available for the period up to 1857 since all Brooke's records at Kuching were destroyed during the Chinese Insurrection. 


\section{CHAPTER VII}

\section{THE PIRATE CONTROVERSY}

When James Brooke was created Raja of Sarawak in 1841, the British commercial world assumed that as soon as he had set up a government he would be asking for financial support. The Singapore Free Press pointed out in an editorial that the means of a private gentleman were insufficient for the purpose in hand, and that the new enterprise could succeed only if full publicity were given to it in India and in England. ${ }^{364}$ It was generally taken for granted that under judicious management Sarawak could become a useful new market for British manufactures and a profitable field for British capital investment. $^{365}$

Brooke knew that his personal fortune was inadequate but, unlike the merchants, he regarded his new kingdom not as an estate to be worked for profit but as an instrument placed in his hands by fortune for the purpose of raising a native population in the scale of civilization. For this reason, although anxious to obtain financial support, he flatly refused to accept it other than on the terms he himself laid down. One cannot but admire Brooke's high principles, but it is less easy to sympathize with his naive assumption that British capitalists could be persuaded to invest money in Sarawak primarily to improve the condition of the inhabitants and only secondarily in the hope of obtaining dividends.

One member of the commercial world who certainly did not share the White Raja's scruples was his London agent, Henry Wise. From the beginning of his association with Brooke, Wise was sure that if once the White Raja could be made to see the immense commercial possibilities of Sarawak, he would soon abandon his altruistic attitude and agree to entrust his affairs to the capable hands of business men. In taking this view, Wise was the victim of a triple misconception.

364 Issue of January 13th, 1842.

305 G. F. Davidson, for example, devoted a lengthy appendix in his book, Trade and Travel in the Far East (1846), to a description of the methods he considered Brooke should adopt in order to attract capital and labour to Sarawak. 
In the first place, he completely misjudged the White Raja's character, for Brooke was never really interested in trade or profit-making and, like many Victorian gentlemen, rather looked down upon those who were. "Wise ... builds much upon my ignorance of business matters", Brooke drily remarked to his friend, John Templer, on one occasion, "and because I am no merchant he concludes I have no sense". ${ }^{366}$ Secondly, Wise was very much in error in believing Sarawak capable of producing a rapid return on investments. And, thirdly, he seems to have genuinely misunderstood the true nature of Brooke's grant from the Sultan of Brunei. In a letter to Lord Haddington of April 1844, he asserted that the Sultan, imbued with "an anxious desire for a more close and intimate connection with the British Government", had ceded "a valuable portion of his territory at Sarawak... for the purpose of forming a commercial establishment". ${ }^{367}$

To some extent Brooke was himself responsible for raising false hopes in his agent's mind. During the period when the chief concern of both was to obtain British Government recognition for the new settlement, he often made use of expressions which seemed to indicate to Wise, at any rate - that fortunes were almost to be picked up in Borneo for the asking. "For the country", he wrote in September 1841, "what shall I say? I could not wish a richer; its soil is fine, and admirably calculated for the culture of rice, coffee, nutmegs, or cotton". ${ }^{368}$ On another occasion he told his agent: "I do not myself see why this opening should not lead to results similar to India itself". ${ }^{368}$ Finally, and most significant of all, it was Brooke who first put forward a proposal that a company should be formed to develop the resources of Sarawak. Early in 1843 he instructed Wise to investigate the possibility of forming a public company with a capital of "from $£ 300,000$ to $£ 500,000$ ", and recommended that "plantations, diamond mines, etc., and a monopoly of antimony and opium" should be held out as inducements to prospective shareholders. ${ }^{370}$

Wise deduced from these instructions that the way was clear for the exploitation of Sarawak and, since he himself was to share in the profits, considered that his fortune was as good as made. With great

\footnotetext{
368 Letters, i, p. 284.

307 Wise to Haddington, April 12th, 1844. (Borneo Papers, p. 28. My italics).

308 Brooke to Wise, September 24th, 1841. (Ibid., p. 10).

309 Brooke to Wise, March 14th, 1843. (Ibid., p. 11).

370 Wise thought of forming a 'Borneo Company' at about the same time, but the first definite proposal along these lines came from Brooke. (Cf. Brooke to Templer, April 14th, 1843 : Letters, i, p. 256).
} 
enthusiasm he set about the task of interesting the City of London in a Bornean development project. In doing so, however, he used methods which caused Brooke to suspect that a commercial 'bubble' was being promoted. "I trust [Wise] has not committed me by garbling or high colouring my statements", he wrote to Templer in April 1843. "I fear it because ... he has so evidently misconstrued my meaning and expressions about commerce. This annoys me, because I thought I had been guarded enough to prevent any rash commercial speculation". ${ }^{371}$ As time went on Brooke's suspicions were confirmed, and he decided to put a stop to these exaggerated descriptions of Borneo once and for all. "I wish you", he told Templer, "to state plainly and roundly my opinion ... that the N.W. coast of Borneo offers no immediate opportunity for British manufacture, beyond the quantity yearly supplied from Singapore". ${ }^{372}$ Wise, however, continued to use the most extravagant language in the course of his promotion campaign.

The White Raja's determination to prevent the exploitation of Sarawak by speculators became even stronger when the Royal Navy began taking action against the Borneo pirates. As his prestige grew as a result of the exploits of Keppel and Sir Thomas Cochrane, so his need for assistance from the commercial world declined. He ultimately came to the conclusion that a public company would not, after all, be required to ensure the security of Sarawak and that, if he were ever to carry out his true mission of civilizing his subjects, he must break free from the distractions of trade. One of the clearest statements of his views on this point is contained in a letter he wrote in March 1846. "I can in no wise participate", he said, "in profits which may arise out of the formation of a company, or any other project started in England, for it is incumbent on me to continue independent in order to judge correctly the measures calculated to benefit this country, and a correct judgment is only to be formed when all prospects of pecuniary advantage have been discarded, excepting such as flow naturally in the course of time and improvement". ${ }^{373}$ All that Sarawak really needed for stability, he decided, was a safe and steady revenue. In 1846 he succeeded in putting his finances on a more or less satisfactory basis, ${ }^{374}$ and

371 Brooke to Templer, April 13th, 1843. (Ibid., p. 249).

372 Brooke to Templer, August 1843. (Ibid., p. 281).

373 Brooke to Wise, March 1st, 1846. (P.P., 1850, X, p. 1244).

${ }^{374}$ Soon after Brooke became Raja of Sarawak, he commuted all taxation into a single revenue, to be derived from the export of antimony ore. An opium farm was added later, together with some other small levies, such as an annual rice tax on the Dyaks. Before long, however, the funds collected by 
from then on did everything he could to frustrate the commercial penetration of his kingdom.

Such a policy inevitably aroused resentment in the business world. J. R. Logan, the editor of the Journal of the Indian Archipelago, who was willing to give Brooke full credit for humanitarian motives, strongly disapproved of his attitude to commercial enterprise. "With the feelings which lie at the bottom of [his] views", wrote Logan, "we entirely sympathize, but we would earnestly deprecate any attempt to enforce that seclusion from promiscuous contact with Europeans which Sir J. Brooke evidently deems it desirable to carry out to a certain extent, if practicable. We think it so impracticable that we might as well attempt to oppose a law of nature". ${ }^{375}$ As an absolute ruler Brooke was of course free to dictate what policy he chose in Sarawak, but protests from the commercial world became more vigorous when he sought to apply similar restrictions to areas of Borneo which were not under his immediate control. Under the terms of Articles II and III of the Treaty of 1847 with Brunei - a treaty Brooke had negotiated British merchants were entitled to trade and acquire property within the Sultan of Brunei's dominions, and merchants taking advantage of these facilities naturally expected to be given protection and support by the official specially appointed by the Government for that purpose, Brooke himself.

The first clash between the White Raja and British speculators occurred as a result of the discovery of antimony ore near the Bintulu, a river which was subject to the Sultan of Brunei. In November 1847 the Singapore firm of Gliddon \& Co obtained a ten-year mining lease of this area in exchange for an annual royalty. ${ }^{376}$ They applied to the

these means were found to be inadequate, and he instructed Wise to arrange for a syndicate to take over the antimony and opium monopolies on a fiveyear lease. The offer was accepted by the firm of Melville \& Street, who agreed to pay an annual royalty of $£ 2,500$. But during the commercial crisis of 1847-8 this firm, like so many engaged in the eastern trade, went bankrupt, and in 1849 the antimony and opium monopolies reverted to Government. The following year the antimony mines were leased to a new syndicate, $R$. and J. Henderson \& Co., and the opium farm was taken over by a member of Brooke's staff at Kuching, and run as a state enterprise. These arrangements remained in force until the Borneo Company began operations in 1856. (Letters, iii, pp. 14 and 123. P.P., 1850, X, pp. 1242-7). The revenues of Sarawak, however, did not meet expenses until after 1850, when a great influx of Chinese from Dutch Borneo occurred. (Spenser St. John, The Life of Sir James Brooke..., p. 65).

375 J. R. Logan, 'Borneo', Journ. Ind. Arch., 1848, p. 496.

376 Gliddon \& Co to Rear-Admiral Inglefield, December 7th, 1847. (C.O. 144/2). 
Admiralty ${ }^{377}$ for ratification of their lease, but were told that no decision could be given until Sir James Brooke had had time to go into the matter on his return from Europe. An examination of the antimony fields, however, convinced them that the ore could not be landed at Singapore under $\$ 1.65$ a pikul, at which price mining operations would be uneconomic, and they lost interest in the scheme. ${ }^{378}$

In the meantime an independent adventurer named Robert Burns had prevailed upon the Singapore representative of Hamilton, Gray \& Co to lend him sufficient capital to obtain a concession in the same area. Burns was a grandson of the poet and had already gained considerable experience in Borneo, where he had shown himself to be an explorer of no mean ability. He was the first European to make an excursion into the far interior of the Sultanate of Brunei, and contributed a valuable description of the Kayan people to the Journal of the Indian Archipelago. ${ }^{378}$ Of his character it is difficult to form a just estimate. The quality of his writing shows that he was far from being the "disreputable adventurer" of the Sarawak histories, and the fact that he succeeded in living for some time among the wild Kayan argues that he can hardly have been as tactless and overbearing as has sometimes been suggested. On the other hand he undoubtedly had a fiery temper, was crude and predatory (particularly where women were concerned), and by the standards of his time was not an ideal representative of western civilization in the Eastern Seas. ${ }^{380}$

Burns arrived at Brunei early in 1848. After an argument with the Sultan and his ministers, he secured an antimony concession and proceeded to look over the ground at Bintulu. He had been there a month when a letter arrived from A. C. Crookshank, Brooke's deputy at Kuching, advising the chiefs of Bintulu that they need not work the antimony mines unless they and their peoples genuinely wished to do so. ${ }^{381}$ But Burns persuaded the chiefs to pay no attention to this letter.

Soon afterwards Brooke himself returned to the East, clothed in his new dignity of Governor of Labuan. On the way through Singapore

377 From December 1846 (when Labuan became a British possession) to September 1848 (when its Government first began to function) the Admiralty were responsible for the administration of British policy in north-western Borneo.

378 Gliddon to Hume, November 25th, 1851. (P.P., 1852, XXXI, p. 452).

379 R. Burns, 'The Kayans of the North-West of Borneo', Journ. Ind. Arch., 1849, pp. 138-52.

380 Cf. Tom Harrisson, 'Robert Burns - the first Ethnologist and Explorer of Interior Sarawak', The Sarazwak Musenim Jourmal, November 1951, pp. 463-77.

381 Crookshank to the Chiefs of Bintulu, January 5th, 1848. (P.P., 1852-3, LXI, p. 347). 
he told Mr. Nicol, the representative of Hamilton, Gray \& Co, that the time was not opportune for working antimony at Bintulu, ${ }^{382}$ and when he reached Kuching he sent a letter to the chiefs which was couched in far stronger language than Crookshank's had been. "I request that in future", he wrote, "whenever an Englishman [sic] does wrong like Mr. Burns, my friends will order him out of their country, and hold no intercourse with him ... Every English trader must obey the Government of the country in which he carries on his business... Let the traders, therefore, in my friends' country, be confined to their own business; and if they represent themselves to be great people, possessed of power, or talk as Mr. Burns talked, my friends will know that they speak falsely, and are men without shame". 383

This letter was conveyed to Bintulu by the East India Company's steamer, Phlegethon. When its contents became known, the chiefs refused to have anything more to do with Burns, and he was obliged to return by the steamer to Singapore. He later went back to Brunei in order to recover his lease money, but lost his temper when discussing terms with the Sultan and behaved generally in such an insulting manner that he would almost certainly have lost his life then and there had the Brunei perngerans not been afraid of Raja Brooke's vengeance. ${ }^{384}$ After this incident the Sultan wrote to Brooke to say that he would be grateful if Mr. Burns were dissuaded from visiting the antimony fields again. ${ }^{385}$ Burns retired to Labuan and spent some time trying to persuade the fishermen there to ferry him over to Bintulu, but they were all too much in awe of the White Raja's displeasure to agree. $\mathrm{He}$ then chartered a merchant schooner and began trading along the coast. Before long, however, he was in trouble again, on one occasion for defaulting on debts and on another for assaulting the captain of his own schooner. His chequered career came to an abrupt end in September 1851, when he was murdered by pirates in Marudu Bay.

Robert Burns may well have been something of a scoundrel and a 'general undesirable' and it is possible that if Raja Brooke had not engineered his expulsion from Bintulu blood would have been shed.

382 An unnecessary warning, as it turned out, since Nicol had already decided that the Bintulu speculation was a bad one. (Nicol to Brooke, March 30th, 1852 : P.P., 1852, XXXI, p. 545).

383 Brooke to the Rajas of Kayan and Kinneah (n.d.). (P.P., 1851, XXXVI, pp. 5-6). See also Maeander, ii, p. 92.

384 'Minutes of a Conversation between Mr. Low and Pangeran Makota', January 11th, 1849. (P.P., 1852, XXXI, pp. 546-8).

385 Sultan of Brunei to Brooke, Rabi' II, 1266 (1849). (Ibid., p. 548). 
But it was at least doubtful if the White Raja's treatment of him was consistent with the duties of a British consul-general. Brooke made no attempt to prove or disprove the accusations against Burns before ordering his summary ejection, and the question suggests itself - Who was the White Raja of Sarawak that he should pick and choose between those who were eligible to trade under the privileges of the 1847 Treaty and those who were not? As the North British Mail indignantly demanded: "Why should not Mr. Robert Burns be as free to explore, to open mines, to establish trading relations in the Archipelago as Sir James Brooke? What was Sir James Brooke but a poor friendless adventurer when he began his career in the Eastern Seas? Is Borneo to be less accessible to the enterprise of British subjects since than it was before? So long as Mr. Burns does not poach on Sir James Brooke's manor, we do not see why the latter should be suffered to interfere with him". 386

The whole matter may be summed up by saying that whether the White Raja's handling of the Burns affair was morally justifiable or not, it was undoubtedly questionable at law. Few would cavil at his statement of general principles when he wrote: "Better would it be to abandon our settlements and our trade in [the Eastern Seas] and to leave the native population to its miseries and its own wild sense of justice, than to expose it to the unrestrained licence of European speculators". ${ }^{387}$ But by applying his exclusion policy indiscriminately he was laying himself open to the charge that he was using his official position as Governor, Commissioner, and Consul-General in order to benefit his private position as Raja of Sarawak.

Brooke might have been able to carry through his plan to bar speculators from Borneo had he confined himself to chasing away adventurers like Burns, who had little influence or backing. But when he became involved in a similar dispute with Henry Wise over the exploitation of Borneo coal he was matching himself against a much more formidable adversary. The circumstances surrounding the long battle between Brooke and Wise were immensely complicated, but may be briefly summarized as follows.

In August 1846 the Sultan of Brunei granted Brooke a concession to work "the whole of the coal found in the country extending from

386 Issue of October 7th, 1851. (F.O. 12/12). It must be remembered that a paper like the North British Mail was in honour bound to support a grandson of Scotland's national poet whether he was a scoundrel or not.

287 Brooke to Earl Granville, January 5th, 1852. (P.P., 1852, XXXI, p. 461). 
Mengkabong as far as Tanjong Baram" in return for an annual payment of $\$ 2,000$ for the first year and $\$ 1,000$ for each subsequent year of operations. ${ }^{\mathbf{8 8} 8}$ This constituted a practical monopoly of all coal then known to exist on the mainland of northern Borneo. Brooke had no intention of mining it himself, but had the agreement drawn out in his own name because the Sultan was unwilling to grant a concession to anyone else. ${ }^{389}$ In November, on Brooke's behalf, Wise offered this concession to the British Government, who declined it, but stated that there would be no objection to a private firm taking up the option. ${ }^{390}$ The following October Brooke transferred all his rights in Borneo coal to Wise unconditionally.

Meanwhile the coal beds on Labuan were attracting attention. The previous April Lieutenant Heath, of H.M.S. Wolf, had made a detailed survey of the various seams on the island and had reported favourably on them to Rear-Admiral Inglefield, his Commander-in-Chief. ${ }^{\mathbf{3 8 2}}$ Inglefield contracted with a beachcomber named William Henry Miles to supply Labuan coal to the Royal Navy in the Far East at $£ 1$ a ton. ${ }^{393}$ By scratching at surface outcrops Miles succeeded in producing a small quantity of very inferior coal, which was duly loaded into the bunkers of H.M. Ships calling at the island and later provoked blistering criticism from the engineers who were obliged to use it.

It was at this stage that Wise conceived an ambitious scheme to make a 'corner' in Borneo coal. His first step was to gain control of the fields in Labuan. In January 1848 he secured a thirty-year lease of all coal lying under the surface of 500 acres of land - a sufficient area for his purpose - for a rental of $£ 100$ plus a royalty to government of $2 / 6$ a ton on output in excess of 1,000 tons per annum. ${ }^{394}$ Next he applied to the City of London for the necessary capital to promote a Borneo mining company. He approached R. and J. Henderson and $\mathrm{Co}$, but they would not accept his terms. Other firms were also tried without success. He eventually persuaded Messrs. Melville and

388 'Grant of the Sultan of Brunei', August 23rd, 1846. (Ibid., p. 628).

Brooke to Templer, August 24th, 1846. (Letters, ii, p. 152).

380 British Government permission for the private exploitation of Borneo coal had already been given tentatively in October 1845.

891 Brooke to Wise, October 6th, 1847. (P.P., 1852, XXXI, p. 628). Governor Bulwer to Earl Granville, May 23rd, 1873. (F.O. 12/48).

892 See Forbes, op. cit., pp. 318-22. Forbes was a member of the survey party.

393 Agreement of September 7th, 1847. (C.O. 144/2).

894 Colonial Land and Emigration Commissioners to the Colonial Office, January 26th, 1848. (P.P., 1847-8, XLII, pp. 258-9). 
Anstruther to enter into partnership with him, and with their assistance founded the Eastern Archipelago Company, of which he became the managing director ${ }^{305}$ In July he sold his rights in both Labuan and Brunei coal to this company on terms which were astonishingly favourable to himself, in view of the fact that he had paid nothing for them in the first place. In 'compensation' for the surrender of his rights, he was to receive: $£ 6,000$ within four months of the final organization of the Company, $£ 3,000$ per annum for ten years from the same date, $£ 10,000$ worth of shares, $£ 2-10-0 \%$ of all bonuses and dividends declared, except when the total annual dividend was less than $£ 7-10-0 \%$, and a salary of $£ 800$ a year plus bonuses and percentages. the whole not to exceed $£ 1,800$ in any one year. ${ }^{398}$

Brooke watched these developments with increasing concern. It was most undesirable, in his opinion, for the monopoly of such a strategically important commodity as coal to be in the hands of one man. $\mathrm{He}$ also considered that a royalty of $\$ 1,000$ per annum was an absurdly small sum to be given to the Sultan of Brunei as compensation for the surrender of all the coal in his dominions. Moreover, he further maintained, the grant he had obtained in 1846 was never intended to be exclusive, but only permissive; it conveyed a right to mine coal, not to monopolize it. ${ }^{897}$ Wise disagreed strongly with this view, and both he and Brooke appealed to the Colonial Office, supporting their claims with different translations of the original document of cession. ${ }^{398}$

This argument was in full swing when Brooke learnt with dismay that he had another and more personal reason to be dissatisfied with his London agent. When the firm of Melville \& Street went bankrupt during the commercial crisis of $1847-8$, Brooke lost nearly $£ 10,000$, and he ascribed this disaster, probably correctly, to Wise's faulty handling of his affairs. ${ }^{309} \mathrm{~A}$ year and a half earlier, moreover, a number of letters from Brooke to John Templer containing uncomplimentary references to his London agent had chanced to fall into the latter's

806 Brooke to Grey, November 24th, 1851. (P.P., 1852, XXXI, pp. 803-4).

396 C.O. $144 / 10$.

397 Brooke to Wise, November 20th, 1848. (P.P., 1852, XXXI, p. 632).

388 Brooke to Sir John Pakington, July 22nd, 1852. (P.P., 1852-3, LXI, pp. 349-50).

899 Brooke to Earl Desart, April 10th, 1852. (P.P., 1852, XXI, p. 820). The circumstances of this loss are not clear. Brooke never recovered any damages. St. John once remarked cryptically of his hero, "Mr. Brooke never knew what was the true state of his affairs". (Spenser St. John, The Life of Sir James Brooke..., p. 65). 
hands. ${ }^{400}$ This gave Wise a further reason for bearing a grudge against the White Raja. Each decided that he had been disgracefully treated by the other, and in November 1848 Brooke broke finally with Wise, after an association lasting more than ten years. ${ }^{401}$ From being the staunch supporter and able advocate of Sarawak, Wise immediately became its most bitter enemy, and the dispute over Borneo coal continued more fiercely than ever.

The Eastern Archipelago Company, which began mining operations early in 1849, was a dismal failure from the outset. Shortsightedness on the part of the directors was the main cause of its difficulties. They could not be persuaded to supply their manager at Labuan with sufficient capital to set the enterprise on its feet. On June 20th, 1849, for example, the paid-up capital of the Company was $£ 51,455$. Yet on November 2nd of the same year its Labuan manager was obliged to ask the local Government Treasurer for a loan of $\$ 600$ in order to pay his workmen's wages. Wise, however, laid all the blame for the Company's slow progress on the Labuan Government, and particularly on Governor Brooke, whom he accused of vindictiveness and petty obstruction. Once again both sides carried their dispute to the Colonial Office.

On examination many of Wise's charges against Brooke turned out to be either frivolous or based on plain untruths, but on at least three occasions he scored victories over his opponent by persuading the British Government to reverse rulings Brooke had already given. In April 1850 the Colonial Office consented to a rise in the price of Labuan coal being supplied to the Admiralty, though Brooke was strongly opposed to any change. ${ }^{402}$ The following November Earl Grey decided an argument about the exact limits of the Labuan coal lease in favour of the Company and against Brooke's advice. ${ }^{403}$ And at the end of 1851 the Foreign Office supported Wise's interpretation of the Brunei

400 Admiral Sir Henry Keppel, A Sailor's Life under Four Sovereigns, Vol. ii, p. 63. Jacob, op. cit., Vol. ii, pp. 7-8.

401 In 1838 Wise, then a partner in the firm of Gardner, Urquhart \& Co, had helped Brooke to fit out the yacht, Royalist. When he became the White Raja's London agent at the end of 1841, he withdrew from this concern and founded the house of Melville, Wise \& Co, which later became incorporated with Cruikshank, Melville \& Co. In August 1845 Wise withdrew from this partnership also in order to devote his full attention to Bornean affairs.

402 Minute by Earl Grey, April 26th, 1850. (C.O. 144/6).

403 Grey to Brooke, November 21st, 1850. (P.P., 1852, XXXI, p. 789). Minute by Herman Merivale. (C.O. 144/4). 
coal concession in preference to the White Raja's. ${ }^{404}$ These were minor triumphs in themselves, for they brought about no improvement in the fortunes of the Eastern Archipelago Company, but they had a detrimental effect on the relations between Sir James Brooke and the British Government, which were already showing signs of friction.

Brooke's period of office as Governor of Labuan was perhaps the least successful episode in his otherwise spectacular career. The real trouble was that in accepting the position he had taken on more responsibility than one man could bear. He was already the Raja of an independent kingdom - a task which would have kept most men more than fully occupied - and his duties as British Commissioner and Consul-General involved him in a great deal of travelling. During the whole of 1849 he spent only thirty-nine days at Labuan itself. ${ }^{405}$

But, apart from this, it must be admitted that the White Raja, by both character and past experience, was ill-suited for an appointment in the public service. He was too fond of having his own way and too impatient of interference in his plans. He also never lost sight of the fact that Great Britain would never have achieved her present position in Borneo if it had not been for his efforts and his sacrifices. Captain Keppel, who loyally supported Brooke on every other occasion, had little favourable to say about his administration of Labuan. "Never, my dear Wise", he told the former agent in September 1849, "did you ever make such a mistake as when, with indefatigable labour and perseverance, you raised that misshapen, useless structure, the Labuan government; I believe the Eastern Archipelago Company would have been thriving had that government never been formed... My friend Brooke has as much idea of business as a cow has of a clean shirt. Napier ${ }^{408}$ is no better... Scott, the Civil Engineer, ${ }^{407}$ is a clever, first-rate man; he has done the only good that has been done, and is the only person that ought to have been sent out... I can assure you that I am not sorry to be moving away from this station". ${ }^{408}$

404 Foreign Office Memorandum of November 28th, 1852. (F.O. 12/35). Minute by Herman Merivale. (C.O. 144/7). Earl Granville to Brooke, December 31st, 1851. (P.P., 1852, XXXI, p. 669).

405 Evidence of Earl Grey before the Select Committee on Army and Ordnance Expenditure, June 14th, 1850. (P.P., 1850, X, p. 653).

406 Lieutenant-Governor William Napier, who was later dismissed by Brooke, perhaps unjustly and certainly on inadequate evidence, for inefficiency and peculation.

407 J. Scott (more properly the 'Government Surveyor') who later became Governor of British Guiana.

108 Keppel to Wise, September 2nd, 1849. (C.O. 144/6). 
It would be quite unfair, however, to ascribe all the early difficulties of Labuan to incompetent administration. Brunei was hostile to the new colony from the first, partly for reasons of commercial rivalry, ${ }^{409}$ and partly because slaves from the mainland often sought sanctuary at Labuan in the hope of gaining their freedom. An outbreak of malaria also gave the colony a bad name, and the merchants of Singapore were slow to take advantage of its possibilities as a trading centre. But the fact remained that during Brooke's governorship Labuan fulfilled none of the purposes for which it had been founded, and cost the British Exchequer an average of $£ 9,000$ a year to maintain.

The White Raja returned to England for health reasons in the spring of 1851. Soon after his arrival he instituted legal proceedings against the Eastern Archipelago Company for fraud. He eventually won this case and the Company's charter was revoked, but from every point of view it was unfortunate that the instigator of the action had been the Governor of Labuan. The Company were able to claim, with considerable justification, that the duties of a British governor did not include attacking the only commercial concern which had so far been established in his colony, and which he had been specifically instructed by the Colonial Secretary to protect.

Between 1847 and 1851, by trying to exclude European speculators from Borneo and by pursuing the Eastern Archipelago Company all the way from the coal mines of Labuan to the Court of Queen's Bench in London, the White Raja drew upon himself the hostility of a powerful section of the British commercial world.110 By following courses of action which suggested that when the interests of Sarawak were involved he was liable to forget his responsibilities as an official of the British Government, he damaged the reputation he had won for impartiality and strict personal integrity. Only if these two considerations are borne in mind is it possible to understand the astonishing virulence of the attacks which he now had to face, both in the press and in the House of Commons, against the measures he and the Royal Navy had been taking to suppress piracy along the north-west coast of Borneo.

By the middle of 1849 six years had gone by since Captain Keppel's

400 Brooke to Palmerston, January 9th, 1851. (F.O. 12/9).

410 The directors of the Eastern Archipelago Company included the Earl of Albemarle, Sir James Campbell, Mr. Hamilton Lindsay, Captain Nairne (a director of the P. \& O. Co), and Captain Bethune, R.N. 
assault on the Saribas, and five since his expedition against the Sĕkrang. Both these pirate communities had consequently had ample time to forget the lesson they had received from the 'gallant Didos' and had relapsed once more into indiscriminate marauding. As a result, when in September 1848 Keppel and Brooke returned to Sarawak in H.M.S. Maeander on their way to establish the Government of Labuan, they realized that the work of suppressing Dyak piracy would have to be undertaken all over again. The Sultan of Brunei appealed for their assistance, ${ }^{411}$ and they both publicly pledged themselves to crush the Saribas and the Serkrang as soon as the arrival of the dry monsoon of 1849 made "boating operations" possible. ${ }^{412}$ But to Brooke's dismay the Maeander was ordered to China almost immediately, and plans for large-scale expeditions against the pirates had to be temporarily abandoned.

The White Raja did what he could with his own resources to keep them in check, and demanded fresh naval support. After an acrimonious correspondence with Rear-Admiral Sir Francis Collier, C.-in-C. of the Far Eastern Station, who considered that the Navy had more important work to do elsewhere, he eventually secured the services of H.M.S. Albatross (Commander Farquhar), ${ }^{413}$ and on July 24th, 1849, a powerful force set sail from Kuching for an assault on the pirates of Saribas. In addition to the boats of the Albatross, the expedition included H.M. Brig Royalist, H.E.I.C.S. Nemesis, the steam-tender Ranee, Brooke's personal war-prahu (the Singh Rajah), and seventy native prahus manned by 2,500 Dyak auxiliaries. ${ }^{414}$

Information had been received that a large bala, or pirate fleet, was making its way back to Saribas after a raid on the River Rajang, fifty

411 Sultan of Brunei to Brooke (n.d.). (P.P., 1850, LV, pp. 32-3).

412 Brooke to Palmerston, February 2nd, 1850. (Ibid., p. 30). Spenser St. John, The Life of Sir James Brooke..., p. 170.

413 In June when it seemed likely that the Albatross was about to be withdrawn without firing a shot, Brooke protested to Collier: "I was not aware until I perused your recent communication that Her Majesty's Ships were commissioned for non-employment in the public service". (C.O. 144/3). This is Brooke at his worst. It was certainly no way for the Governor of a small British colony to address a Rear-Admiral Commanding-in-Chief, least of all Sir Francis Collier, whose choleric temper is sufficiently indicated by the following story: "He had once been summoned before a bench of magistrates, and having uttered a great oath the chairman fined him five shillings for swearing. He looked grimly at the bench of three magistrates, drew a gold coin from his pocket, threw it on the table, and said, 'D - . - your eyes all round, and that will make up the sovereign'". (Spenser St. John, The Life of Sir James Brooke..., p. 146).

414 Maeander, i, pp. 148-50. 
miles up the coast to the north. Brooke and Farquhar decided that their best plan would be to ambush this fleet on its return, and disposed their forces so as to cover all possible entrances to the enemy's strongholds. On the night of July 31 st the pirates fell into the trap. 88 Saribas prahus were destroyed and about 300 pirates killed outright; a further 500 died later in the jungle or after reaching their homes. Spectacular destruction was caused by the steamer, Nemesis. At the height of the action she drove right through the struggling mass of prahus, catching up boats and occupants in her paddle-wheels and crushing them to a pulp. The total casualties on the British side were "two natives killed and about six wounded".415

Such was the famous 'Battle of Batang Marau', the greatest blow ever struck at Dyak piracy, and the immediate cause of the attack upon the policy and reputation of Sir James Brooke..16 For the next four years every aspect of the White Raja's rule in Borneo was to be the subject of the most intense controversy, both in England and in the East. Singapore society resolved itself into 'pro-Brooke' and 'antiBrooke' factions, the Free Press supporting and the Straits Times opposing him. In London the Times, the Westminster Revierw, and other papers declared in his favour, while the Daily Neres, the Spectator, and the Examiner were against him. In the Houses of Parliament the problems of Borneo were discussed with an interest never shown before.

Criticism of the White Raja took two main forms. He was attacked in his private capacity as sovereign of Sarawak, and in his public capacity as a servant of the British Crown. Of the two, the campaign to destroy his personal reputation was the more violent and the less justifiable. It was led by the prominent Radical, Joseph Hume, and carried on in the press and on public platforms chiefly by spokesmen of the London Peace Society and the Aborigines Protection Society. Louis A. Chamerovzow, for example, the secretary of the London Peace Society, published a violent attack on Brooke in 1851, entitled Borneo Facts verses Borneo Fallacies. Equally intemperate were A Naval Execution, by 'W.N.', and Adventures of Sir James Brooke, K.C.B., Rajah of Sarazeak, "Sovereign de facto of Borneo Proper",

415 Farquhar to Collier, August 25th, 1849. (P.P., 1850, LV, p. 18).

416 An exaggerated account in the Straits Times of an engagement between the Nemesis and a Balanini fleet in 1847 had already aroused some unfavourable comment, but it was the action at Batang Marau which provoked the real assault on Brooke's Borneo policy. 
late Governor of Labuan, by George Foggo. Many of the accusations made in these works were taken up by contemporary newspapers and periodicals, apparently without any attempt at verification. None is worth refuting in detail. The authors betray a total ignorance of Bornean affairs and many seem to have had no qualifications for undertaking the task of explaining them. Foggo, for instance, was 'Secretary to the National Monuments Association'.

The burden of complaint in these publications and manifestos was that Sir James Brooke had started an unholy crusade against "innocent natives" and "peaceable traders" in order to advance his private interests. He was a "butcher" who had "murdered the savages into subjection". He had created pirates where there were only poor uncivilized Dyak tribes engaged in occasional civil war. He had persuaded the Royal Navy to suppress these harmless children of nature not because they merited punishment but because they had refused to submit to his tyrannical rule.

This whole indictment rested on the assumption that, properly speaking, there was no such thing as a Dyak pirate. Neither the Saribas nor the Sěkrang, it was pointed out, had yet learnt the use of firearms; they therefore could not be regarded as pirates since they were obviously not a danger to European shipping. ${ }^{417}$ It was certainly true that Dyak methods of warfare were unsophisticated by western standards. The Saribas bala demolished by Farquhar, for example, had only four small brass guns in the whole fleet, ${ }^{418}$ and Brooke himself noted in a letter to Lord Palmerston: "Should these pirates become possessed of musketry, which is but too probable, the result must be deplorable". ${ }^{419}$ But it was quite absurd for Hume and his supporters to argue that because the Saribas and the Sĕkrang were not a menace to large European ships they were harmless to small native tradingprahus. His contention that Brooke's 'victims' were only engaged in legitimate civil war was equally preposterous. Their depredations extended for hundreds of miles along the coast, and their attacks were made indiscriminately on Malays, Chinese, Dyaks, or anyone else who had the misfortune to cross their path and had not the strength to resist them.

Hume and the others who assailed the White Raja on personal

417 Speech by Joseph Hume of July 10th, 1851. (Hansard, Ser. iii, Vol. 118, Cols. 443-7).

418 Deposition of the native Siup. (P.P., 1850, LV, pp. 33-4).

419 Brooke to Palmerston, March 6th, 1849. (Ibid., p. 14). 
grounds damaged their case by embellishing it with wild exaggerations and wholesale distortions of the truth. Their speeches and writings reveal that they did not understand the real situation in Borneo, and they were far too ready to believe everything to Brooke's detriment that was reported to them. By quoting garbled extracts from his private journals, ${ }^{420}$ and by relying on the evidence of incompetent and inaccurate witnesses, they weakened an indictment which, with the use of greater subtlety, could have been made very much more formidable. Brooke realized this, and commented shrewdly: "They are asses to have pushed the attack with such perceptible malignity and personality; a cooler tone would have answered their purpose better". ${ }^{421}$

Hume was on comparatively firm ground, for example, when he charged the White Raja with unnecessary cruelty. Many observers were appalled at the apparently heartless manner in which hundreds of savages had been struck down by British guns on the coasts of Borneo without having the means or the opportunity to fight back. ${ }^{422}$ Brooke's employment of Dyak auxiliaries also came under criticism; ${ }^{423}$ the communities from which they were drawn, it was claimed, were indistinguishable from those against which they had been sent. Some of his friends undoubtedly did him considerable harm by publishing highly-coloured accounts of the scenes of carnage which accompanied many of his expeditions. Horace St. John, for example, writing in 1852 , at the height of the controversy, gave the following description of Keppel's assault on the Sĕkrang: "A great conflict took place,

420 Brooke gave his journals to Captain Keppel with instructions that they were to be published if it were considered desirable. Keppel submitted them in the raw' to Mr. Jerdan, the editor of the Court Journal, who allowed Wise to see them. (Keppel, A Sailor's Life under Four Sovereigns, Vol. ii, pp. 31 and 63). When the proof of the first edition came from the printers, Wise persuaded the publishers to suppress it, on the ground that the journals as they stood would cause a scandal. He later claimed that he saved the White Raja's reputation by deleting several passages which gave especially grim details of operations against the Borneo pirates. This claim has been generally believed, but a comparison of the suppressed edition (a copy of which is in the British Museum) with the published version shows that the only important deletions made by Wise were some of Brooke's more outspoken criticisms of the Government of the Netherlands Indies.

421 Jacob, op. cit., Vol. ii, p. 29.

422 Cf. A. Audiganne, 'Politique coloniale de l'Angleterre: expédition de Bornéo', Rerme des Deux Mondes, 1846, pp. 645-70.

${ }^{423}$ Cf. D. C. Steyn Parvé, De handelingen van Sir James Brooke op Borneo, getoetst aan de officiële Engelsche bescheiden en de bestaande traktaten, pp. 140-65, and the 'Letter from fifty-three merchants of Singapore', to J. Hume, January 1851 in P.P., 1852, XXXI, pp. 489-92. 
thousands being engaged on both sides - a mass of boats drifting along the stream, while the Dyaks were spearing and stabbing each other, decapitated trunks, and heads without bodies - scattered about in ghastly profusion. The result of all these operations was most satisfactory". ${ }^{224}$

Brooke was ruthless in his treatment of the Saribas and the Sěkrang but he cannot fairly be accused of inhumanity. There were numerous occasions on which he restrained his followers from unnecessary brutality, and he always tempered justice with mercy whenever he considered that circumstances warranted it. But he believed that tribes like the Saribas could be persuaded to abandon their marauding practices only by being taught to respect the power of a British fleet. "A system of piracy", he wrote, "can only be put down by a system of repression; it requires knowledge, and a course of alternate severity and conciliation to effect it". ${ }^{425}$ There can be no doubt that this policy was the right one. After Farquhar's attack of July 1849 the Saribas abandoned piracy altogether, and settled down to trade and agriculture. ${ }^{426}$ They would never have deserted their traditional occupation if it had not been for the grim lesson of Batang Marau.

The real instigator of the personal defamation campaign against the White Raja was his discarded agent, Henry Wise, who supplied Hume and others with most of the 'evidence' which was presented on their side during the controversy. Bitterly resentful at not being allowed to speculate freely in Borneo, Wise suddenly discovered in 1849 that Brooke's operations against the pirates, against which he had made no murmur of protest during the preceding five years, were "dreadful proceedings ... unjustifiable on the ground of justice and humanity". ${ }^{127}$ It was Wise, too, who initiated most of the complaints which were made against Brooke's actions as a servant of the Crown, and in the long run these caused more damage to the White Raja's standing with the British Government than all the vituperative assaults on his private character. ${ }^{428}$

424 Horace St. John, The Malay Archipelago: its History and Present State, Vol. ii, p. 292.

$425 \mathrm{~J}$. Brooke, 'Memorandum on Piracy', July 31st, 1852. (P.P., 1852-3, LXI, p. 346).

226 Spenser St. John to Lord Malmesbury, September 21st, (Ibid., p. 374).

427 Wise to Lord John Russell, November 26th, 1849. (P.P., 1850, LV, p. 1).

428 It is not possible to indicate here more than the essential features of Hume's case against Raja Brooke. His accusations fill scores of folio pages in the Parliamentary Papers from 1850-54. A summary of his views may be found 
Criticism of Brooke in his capacity of British Commissioner and Consul-General in Borneo and Governor of Labuan was expressed at various times by Gladstone, Cobden, Bright, Sidney Herbert, and the Earl of Ellenborough, as well as by Joseph Hume and several other political figures of less importance. Unlike Hume, none of these statesmen was biassed against the White Raja personally. Cobden's primary object, for example, was to force the British Government to abandon their policy of allowing the Royal Navy to be used to further the White Raja's aims. In a letter to John Bright of December 1849, after deploring the "sentimental mania which gave Brooke all his powers of evil", Cobden wrote: "It shocks me to think what fiendish atrocities may be committed by English arms without rousing any conscientious resistance at home, provided they be only far enough off, and the victims too feeble to trouble us with their remonstrances or groans... The Peace Society and the Aborigines Society are shams if such deeds go unrebuffed. We cannot go before the world with clean hands on any other question if we are the silent spectators of such atrocities". ${ }^{429}$ Gladstone's purpose, too, was to discredit the administration which had sanctioned Brooke's policy, not to attack the White Raja's character. He blamed the Admiralty and the Foreign Office, not Brooke, for the "butchery" which had occurred at Batang Marau. In his opinion, British ships should not have been allowed to participate in the action in the first place. He declared that Sir James Brooke was "a man of philanthropy truly Christian", and refused to support Hume's demand for a public inquiry on the grounds that it was framed in such a way as to hold the wrong party responsible. ${ }^{430}$

Strangely enough, interest in Bornean piracy was first aroused in the House of Commons by a matter which had no direct connection with Sir James Brooke at all. Early in 1850 a number of extremely heavy claims for head-money were submitted to Parliament in respect of naval operations on the coasts of Borneo and nearby islands, and Radicals like Cobden, Bright, and Hume were quick to rise in protest against what they regarded as a disgraceful waste of public funds. In accordance with an Act of 1825, the crews of H.M.

in the pamphlet he published in 1853, entitled $A$ Letter to the Right Honourable the Earl of Malmesbury... relative to the Proceedings of Sir James Brooke, K.C.B., etc., etc., in Borneo. (Copy in the India Office Library).

429 Quoted in John Morley, The Life of Richard Cobden, Vol. ii, pp. 55-6.

430 Speech of July 10th, 1851. (Hansard, Ser. iii, Vol. 118, Col. 485). See also W. E. Gladstone, 'Piracy in Borneo and the Operations of July 1849', The Contemporary Review, 1877, pp. 181-98. 
Ships engaged in operations against pirates were entitled to a reward of $£ 20$ for each pirate taken or killed during an attack, and $£ 5$ for every 'piratical person' not taken or killed but known to have been alive at the beginning of the battle. ${ }^{431}$ The Act was designed to encourage the suppression of piracy in the West Indies, and was passed at a time when numerous freebooters were operating in that area under letters of marque purporting to be issued by certain of Spain's insurgent South American colonies. ${ }^{42}$ The scale of awards laid down may have been appropriate to the conditions of the West Indies in 1825, but it seemed startlingly generous when applied to the results of naval engagements in the East Indies twenty years later.

For their services at the Battle of Batang Marau Commander Farquhar and his men received $£ 20,700$. The calculations were made as follows: 500 pirates 'destroyed' at $£ 20$ per head equals $£ 10,000$; 2,140 pirates 'dispersed' at $£ 5$ per head equals $£ 10,700$; total, $£ 20,700$. ${ }^{433}$ Farquhar was promoted for his efficient handling of the operation, and his personal share of the head-money awarded was $\notin 2,757$. This was handsome pay for one night's work by any standards, especially as the British part of the force had sustained no casualties and had really been in very little danger. The Earl of Ellenborough complained in the House of Lords that head-money was being paid out for the destruction of Borneo pirates armed with spears and swords at a rate which was "four times the amount... given to those who captured or destroyed ships and vessels in action with a national enemy". ${ }^{434}$

The head-money system was also regarded with suspicion because on most occasions the only witnesses of the Royal Navy's battles with pirates in the Eastern Seas were the sailors themselves. Since no one could look over their shoulders, the temptation to submit inflated figures of enemy casualties must have been strong indeed. In at least one case it seems to have been irresistable. When H.M.S. Samarang had a brush with some prahus off the coast of Halmahera in June 1844, her crew were awarded $£ 11,900$ head-money. Evidence collected later suggests

431 'An Act for encouraging the Capture or Destruction of Piratical Ships and Vessels', 6 Geo IV, Cap. xlix.

432 William Senior, Naval History in the Law Courts, pp. 100-1.

433 'Certificate of Recorder of the Court of Judicature of Prince of Wales Island, Singapore and Malacca', October 8th, 1849. (P.P., 1850, LV, p. 24). Headmoney return, referring to operations of July 31st, 1849. (P.P., 1851, LVI, Pt. i, p. 155). Buckley, op. cit., Vol. ii, p. 509.

434 Speech of April 18th, 1850. (Hansard, Ser. iii, Vol. 110, Col. 483). 
not only that the number of enemy was exaggerated, but that in all probability some of the prahus attacked were not pirate vessels at all. ${ }^{435}$ According to contemporary Dutch accounts the vessels engaged by Belcher's force were korra korras which belonged to the Residency of Ternate and were returning home after making their annual politietogt (police-trip) to the coasts of New Guinea. Belcher claimed that 350 'pirates' were killed in the action off Halmahera, but the figures given by the Dutch Resident of Ternate (who presumably would have had no reason for scaling them down) were 16 killed and 40 wounded. ${ }^{436}$

The Act of 1825 was repealed early in 1850, and replaced by one a good deal less accommodating. Soon afterwards the House of Commons was presented with a bill for $£ 100,000$ representing the amount of head-money earned by the Navy during the previous year's operations. Payment was agreed to, despite strong protests from the Radicals. ${ }^{437}$ Brooke, as the author of the policy which had made these awards possible, received a large measure of the blame, though he himself did not benefit from them financially.

The White Raja also came under fire from Hume, Sidney Herbert, and others for combining the Governorship of Labuan with private trading activities at Sarawak. In Herbert's opinion, this "could not be otherwise than prejudicial to the interests of the Crown". ${ }^{438}$ Brooke's defence was that he had not personally been involved in direct commercial transactions since leasing the Kuching antimony mines in 1846 - two years before taking up an appointment in the public service - and that all profits derived from the sale of antimony had been, and were still, devoted to the expenses of the State of Sarawak. ${ }^{439}$ Earl Grey had already explained to a Parliamentary Select Committee in 1850 that at the time the Government had seen no valid reason why Brooke should not retain possession of Sarawak concurrently with holding public office, ${ }^{440}$ but Brooke's critics were not satisfied. They produced a wealth of evidence, supplied by Wise, which seemed to

435 Marryat, op. cit., p. 54. William Senior, 'An Early Victorian Windfall', The Mariner's Mirror, 1911, pp. 80-3. Cf. Rutter, The Pirate Wind, pp. 133-43.

436 Resident Helbach to the Governor of the Moluccas, June 11th, 1844. (Buit. Zaken, No. 3133).

437 'Debate on the Navy Estimates', May 23rd, 1850. (Hansard, Ser. iii, Vol. 111, Cols. 294-311).

438 Sidney Herbert to Brooke, July 1st, 1852. (Letters, iii, p. 130).

439 Sir James Brooke, $A$ Vindication of his Character and Proceedings ..., p. 17. Brooke to Templer, October 11th, 1850. (Letters, iii, pp. 14-15). Templer to Hawes, July 2nd, 1850. (P.P., 1850, X, p. 1242).

440 P.P, 1850, X, p. 655 . 
show that the White Raja had discriminated unfairly against British merchants who attempted to trade freely in Borneo. Gliddon, the onetime speculator in Bintulu antimony, for example, accused Brooke of "trafficking jealousy and unscrupulous malevolences".411

Nevertheless, up to the end of 1852 all Hume's efforts to persuade the House of Commons to order an official investigation into the affairs of Borneo ended in failure. ${ }^{42}$ In December of that year, however. Lord Derby's Government fell, and a coalition headed by the Earl of Aberdeen took its place. The new cabinet included Gladstone and Sidney Herbert, both critics of the White Raja. When the new Prime Minister consented to a Commission of Inquiry in March 1853, it was assumed by Brooke's friends that he had done so because of pressure from Gladstone and Herbert, and because the support of Hume and the Radicals was needed if the coalition were to survive. The White Raja, it has been said, was "thrown to them [i.e. the Radicals] as a peacesop". ${ }^{43}$ The truth was, however, that Aberdeen and his Foreign Secretary, the Earl of Clarendon, had a sufficient reason of their own for wanting an inquiry into Bornean affairs.

When Brooke was arranging matters in Brunei after Admiral Cochrane's attack on the capital of July 1846 , he took the opportunity of obtaining from the Sultan a fresh title to his kingdom of Sarawak. ${ }^{444}$ "The Lord Sultan", stated this document, "grants the province of Sarawak... unto the Tuan Běsar, James Brooke, Esquire ... to be ruled in accordance with the wishes of the Tuan Běsar ..." 445 No mention was made of annual tribute, though the sums to be paid by the White Raja to the Sultan and other Brunei nobles had been specified in all previous agreements. (The stipulation was retained, however, that $\$ 4,000(\mathrm{Sp})$ would be paid to Brunei on the demise of Brooke or of his heirs.) From 1846 onwards, therefore, the State of Sarawak was de facto independent of Brunei.

A Foreign Office Memorandum of January 1853, however, reveals that the British Government had not yet recognized this change in status. Indeed, until Hume brought the matter to public notice in March 1852, the Government were not even aware that a fresh grant had been made. The Memorandum notes further that Brooke had

441 Gliddon to Hume, November 25th, 1851. (P.P., 1852, XXXI, p. 458).

442 Hume's motions demanding an inquiry were defeated by overwhelming majorities: July 1850,169 to 29 ; July 1851,230 to 19.

443 L. A. Mills, 'British Malaya 1824-1867', JRASMB, November 1925, p. 261.

444 See pp. 125-6 above.

445 Grant of August 2nd, 1846. (Maxwell and Gibson, op. cit., p. 186). 
acquired his new title before he received an appointment as British Commissioner, and asks: "Would such a commission have been issued had Her Majesty's Government considered him as an independent Prince ?" 448

It seemed to both Aberdeen and Clarendon that Brooke's claim to unrestricted sovereignty over Sarawak, and also the charges which had been laid against him of hindering British commercial enterprise in Borneo needed closer examination. A convenient method of doing this would be by means of the Commission of Inquiry for which Hume and others had been pressing for so long. "The incompatibility of [Brooke's] character of Rajah and Consul", wrote the Prime Minister in a private note to the Foreign Secretary, "his relations with native chiefs, and his employment of British forces in their internal disputes afford reasonable grounds for inquiry. Complaint has been made that the general interests of British commerce have been injured by the position of Sir J. Brooke, and the influence exercised by him in support of his own monopoly... Sir J. Brooke should be informed of our intentions, but I would bring no charges, although, of course, complaints must be received. On our part, it should be a fair and impartial inquiry". ${ }^{447}$ Accordingly, when Clarendon issued instructions for a Commission, he stated that the first question it had to answer was whether the White Raja's position at Sarawak was "compatible with his duties as British Consul-General and Commissioner for Trade, and with his character of a British subject". And he added this warning for the Commission's guidance: "It is to be observed that by no act of Her Majesty's Government has countenance ever been given to Sir James Brooke's assumption of independence, and that his possession of Sarawak has never been considered otherwise by them than as a private grant". 448

When the Government's decision to hold an inquiry was first announced, Brooke welcomed it, for he felt confident that an impartial investigation would finally clear him from Hume's vindictive charges. ${ }^{440}$ But his attitude changed abruptly when he learnt the Commission's terms of reference, and he protested vigorously to Clarendon that the independence of Sarawak had long been recognized and had never been

446 Foreign Office Memorandum of January 16th, 1853. (F.O. 12/14).

447 Aberdeen to Clarendon, March 24th, 1853. (Abercieen Papers: British Museum Add. MS. 43188, p. 56).

448 Clarendon to Sir Charles Wood, June 21st, 1853. (Jacob, op. cit., Vol. ii, p. 91).

449 Brooke to Clarendon, April 4th, 1853. (F.O. 12/13). 
questioned by any previous Foreign Secretary. ${ }^{450}$ Brooke was seriously in error here. The truth was that the matter had never received detailed consideration. Even Lord Palmerston, one of the White Raja's staunchest supporters, confessed in 1850 that he found it quite impossible to comprehend the precise nature of the relationship between Sarawak and the Sultanate of Brunei. 451

The Commission "appointed to inquire into certain matters connected with the position of Sir James Brooke" conducted its investigations at Singapore, and was in session from September 11th to November 20th, 1854. It consisted of two members, Messrs. Prinsep and Devereux, both of the East India Company's service. On the charges of trading while holding public office and of obstructing the Eastern Archipelago Company, the Commissioners exonerated the White Raja completely, but they decided nonetheless that his position as ruler of Sarawak was incompatible with his holding office under the Crown - a decision of academic interest only, since he had resigned all public appointments simultaneously with protesting against the Commission's terms of reference the previous September. ${ }^{\mathbf{4 5 2}}$ Neither Commissioner was in any doubt about the piratical nature of the Saribas and the Serkrang; but, whereas Devereux believed that the punishments inflicted on them had been "just and expedient", Prinsep thought that Brooke's practice of "acting in consort with savage allies" made it undesirable that he should be entrusted with power to call for British naval support against piratical tribes. The Commissioners also failed to agree on an answer to the most important problem they were called on to solve - the nature of the White Raja's position at Sarawak. Prinsep held that Brooke was "a vassal of the Sultan of Brunei", though admittedly "holding by a tenure very lax and easy to be thrown off altogether"; while Devereux, who was prepared to concede that Sarawak was in fact independent of Brunei, expressed a doubt whether Brooke, as a British subject, could "attain to the position of being an independent ruler of a foreign country". 458

Thus, although the White Raja emerged from his long ordeal with his personal reputation undamaged, the findings of the Singapore Commission of Inquiry were unsatisfactory to him and his supporters from every other point of view. Sarawak was now farther than ever

450 Brooke to Clarendon, September 27th, 1853. (Ibid.)

451 Minute by Lord Palmerston, October 12th, 1850. (F.O. 12/8).

452 Brooke to Clarendon, September 24th, 1853. (F.O. 12/13).

453 'Reports of the Commissioners'..., P.P., 1854-5, XXIX, pp. 4-21. 
from recognition either as a British colony, which he had originally hoped it would be, or as a state in its own right, which he was beginning to realize it would have to become if it was to survive. The mere fact that an inquiry had been held, moreover, had two far-reaching consequences. The interrogations to which he had been subjected not only embittered Brooke towards the British Government, with the result that relations between Sarawak and the Foreign Office deteriorated from this time onward, but also seriously damaged his reputation with his Bornean subjects. Sarawak was soon to be beset by numerous economic and political difficulties and its ruler, deserted as he thought by Great Britain, and abandoned by the Royal Navy, had every reason to be alarmed at the rapid progress which his Dutch neighbours were making in their efforts to extend their rule in western, southern, and eastern Borneo. 


\section{CHAPTER VIII}

\section{THE DUTCH REACTION}

Until James Brooke established himself at Sarawak, the Dutch did not attempt to exercise more than a nominal sovereignty over their possessions in the southern part of Borneo. Experience had taught them that the island could not be developed either easily or quickly, and during the 1830's, when interest was concentrated on Java and the Culture System, Borneo became a kind of protected reserve, with a few settlements dotted around its coasts to act as signposts warning would-be trespassers not to interfere. Keeping up appearances in this way was expensive, ${ }^{454}$ yet the Dutch never contemplated withdrawing from the island entirely. They assumed that when the resources required to exploit it became available their patience would be rewarded by appropriately rich returns.

Such a policy of neglect was practicable only so long as there was no fear of foreign competition. Thus, when it became clear that Raja Brooke's object at Sarawak was neither scientific inquiry nor trade, the Dutch realized that they would have to safeguard their possessions more efficiently or run the risk of losing them. Sarawak itself was outside their sphere of influence, it was true, but Brooke's success there might easily encourage other fortune-hunters to carve out private king-

454 During the period 1839-62 expenditure exceeded revenue on the Borneo Westkust by f.7.8 million, and on the Zuid-en Oostkust by f.4.2 million. Almost all the other Outer Possessions were equally unprofitable, the respective net deficits being: Benkoelen, $f .2 .5 \mathrm{~m}$; t the Lampongs, $f .1 .5 \mathrm{~m}$.; Palembang, f. $5.5 \mathrm{~m}$.; Riouw, f. $2.7 \mathrm{~m}$.; Celebes, f. $9.8 \mathrm{~m}$.; the Moluccas, f. $8.6 \mathrm{~m}$.; and Timor, f. $0.9 \mathrm{~m}$. The West Coast of Sumatra, however, showed a net surplus of $f .3 .5 \mathrm{~m}$. in the same period, and the profits on tin-mining in Banka were so considerable that they cancelled out the losses sustained elsewhere in the Outer Possessions. Between 1839 and 1862 Banka with Billiton returned the huge net surplus of $f .71 .2$ million.

(These figures are adapted from the 'Verslag van het beheer van Nederlandsch-Indië... over het jaar 1854', Staatscourant, Bijblad, 1856-7, II, xx, 2, pp. 147-50, and from 'De financiëele resultaten van het bestuur der Buitenbezittingen van 1839 tot 1862', De Indische Gids, 1890, ii, pp. 1336-9. For various technical reasons, explained in the second of these authorities, they are approximate only). 
doms for themselves in parts of Borneo over which the Dutch, though possessing sovereign rights, had no actual control. Foreign Governments, too, might be preparing to challenge Dutch power in the island. British and French interest in the Eastern Archipelago generally had shown a marked increase since the opening of trade with China in 1842.

For these reasons the Netherlands Government decided that their existing claims to sovereignty over Borneo and the other Outer Possessions must be more clearly defined and, when this had been done, publicly proclaimed as a guide and as a warning to the outside world. Towards the end of 1842, J. C. Baud, the Minister of the Colonies, ordered a search to be made in the archives at Batavia with a view to codifying the huge mass of contracts and agreements upon which the title of the Kingdom of the Netherlands to its Far Eastern territories was based. ${ }^{455}$ This investigation revealed many gaps and discrepancies, and it was therefore decided to send special commissioners to the Outer Possessions with orders to place Dutch sovereign rights in these areas as far as possible beyond doubt. A 'Commissioner and Inspector for Borneo, Riouw, and Lingga', A. L. Weddik, was appointed in May 1844. 456

Eleven years previously, however, Governor-General van den Bosch had forbidden all activity in Borneo which might conceivably cause the Government unnecessary expense. This meant that officials of the Borneo administration rarely, if ever, moved beyond their headquarters, and were thus completely ignorant of the real state of affairs in the districts over which they ruled. Resident A. M. E. Ondaatje of Bandjermasin, for example, did not once venture up the Barito River even as far as Marabahan during the ten years after he took up his appointment in $1836 .{ }^{457}$

In order to combat the growing threat of foreign interference, therefore, Baud relaxed the restrictions imposed by van den Bosch. In November 1843 he granted permission for Dutch officials in Borneo to undertake "scientific exploration, administrative measures, the sup-

405 Kabinetsrescript of November 3rd, 1843, La G40, Very Secret. Minister of the Colonies to the Governor-General, November 4th, 1843. (Kol., 1843, No. 459/M1, Very Secret). Orders were also issued for new maps to be drawn of all the Netherlands Indian possessions. (See J. E. de Sturler, Het grondgebied van Nederlandsch Oost-Indië in verband met de tractaten met Spanje, Engeland. en Portugal, pp. 37-41.)

456 Besluiten of May 12th, 1844, No. 35, and June 22nd, 1844, No. 2.

157 Weddik to the Governor-General, September 27th, 1846. (Kol., 730a/15). 
pression of small revolts, and the regulation of quarrels. ${ }^{458}$ Even the establishment of new military posts was authorized, although preference, the Minister considered, should be given to the extension of Dutch power by peaceful means, such as the negotiation of fresh contracts, the levying of annual taxes, and the distribution of flags and batons. These batons or canes (stokken) were embossed with the arms of the Netherlands, and were designed to act as symbols of Dutch sovereign power. Three months after Baud issued these instructions, and as if to emphasize the need for them, Erskine Murray arrived in Koetei River on his ill-fated trading venture. ${ }^{459}$ The attention of the authorities in Batavia was thus immediately drawn to the East Coast, with which there had been no official contact of any kind since 1834 .

In the mid-nineteenth century the East Coast of Borneo was ruled by a number of more or less independent native princes, none of whom was comparable in power or influence to the Sultans of Pontianak, Sambas, or Bandjermasin. To the north, bordering on Brunei, lay Tidoeng, or the 'Tidoengsche landen', a cluster of eight paramount chieftainships, nominally subject to the adjoining Sultanate of Boeloengan. South of Boeloengan were Goenong Taboer and Sambalioeng, situated on either side of the River Koeran. These four districts had once formed the Sultanate of Berouw, an ancient kingdom which had been partitioned in 1770 after a civil war; suzerainty over 'Berouw' was claimed by the Sultan of Sulu as well as by the Sultan of Bandjermasin. To the south of Sambalioeng lay Koetei, the largest of the East Coast states, and between Koetei and Tanah Boemboe (the eastern part of Bandjermasin) lay the smaller Sultanate of Pasir. ${ }^{400}$

In 1817 the Sultan of Bandjermasin had ceded the whole East Coast 'in full sovereignty' to the Government of the Netherlands Indies.

458 Minister of the Colonies to the Governor-General, November 4th, 1843. (Kol., 1843, No. 459, $\mathrm{M}^{\mathbf{1}}$, Very Secret). See also H. Colijn, Politiek beleid en bestuurszorg in de buitenbezittingen, Deel i, pp. 29-33, and Stapel, op. cit., Deel v, p. 301.

459 See p. 102 above.

400 'Borneo: staatkundige verhouding van het Nederlandsche Gouvernement, opgemaakt in verband der Nota te zamengesteld bij het Ministerie van Koloniën'. (Kol., 1846, No. 160, Secret). J. Hageman, 'Aanteekeningen omtrent een gedeelte der Oostkust van Borneo', TTLV, Deel iv (1855), pp. 71-106.

Repeated changes of name have been responsible for much confusion in the history of the East Coast of Borneo. Sambalioeng, for example, was known as 'Tandjong' from 1770-1834, and as 'Batoe-poetih' from 1834-50, while 'Berouw' was still being used to describe the area between Koetei and the Sulu border long after the Sultanate of that name had ceased to exist or had been reduced to a shadow of its former self. 
Between then and 1844, however, eastern Borneo had been visited by Dutch officials on only two occasions. In August 1825 George Müller, a former Resident of Sambas, negotiated a contract with the Sultan of Koetei (which was not ratified by Batavia), and in 1834 Dutch warships chastised a Sulu pirate sharif at Batoe-poetih. Following this attack, the rulers of Goenong Taboer and Sambalioeng submitted to Dutch suzerainty and bound themselves to abstain from piracy and protect trade. ${ }^{461}$ Needless to say, these agreements were disregarded as soon as the ships under whose guns they had been signed departed from the coast.

In 1844, therefore, Dutch influence in eastern Borneo was virtually non-existent. This was why Erskine Murray's escapade caused so much uneasiness in Batavia. Admittedly, he and some of his companions had been murdered, but that was not to say that other adventurers might not be more successful. In October Commissioner Weddik was ordered to the East Coast to investigate Murray's death, and also to strengthen the bonds between the local rulers and the Dutch Government. A new contract was obtained without difficulty from Koetei largely, it seems, because the Sultan expected to be punished for the murders, and was thankful to be let off with a caution ${ }^{462}$ - and a fortnight later a similar agreement was secured from the Sultan of Pasir. ${ }^{463}$ During November Lieutenant J. van Capellen of the Dutch Navy negotiated fresh treaties with Boeloengan, Goenong Taboer, and Sambalioeng. All these agreements contained clauses prohibiting Europeans other than those of Dutch extraction from establishing themselves in the territories of the rulers concerned. ${ }^{464}$

Scarcely had van Capellen left the north-east coast when H.M.S. Samarang (Captain Sir Edward Belcher) arrived at Goenong Taboer. Belcher had received word that a British merchantman, the Premier, had been wrecked on a nearby reef, and that her crew were being held to ransom by the Sultans of Goenong Taboer and Boeloengan. On arrival, he was informed that the white members of the Premier's crew had already been rescued by van Capellen, ${ }^{465}$ but he decided to improve the occasion by negotiating provisional treaties of friendship and com-

461 'Algemeen overzigt van de staatkundige gesteldheid van Nederlandsch-Indië over de jaren 1839-1848 (Borneo)'. (Kol., 1851, No. 27 bis, Secret).

402 S. C. Knappert, 'Beschrijving van de onderafdeeling Koetei', BTLV, 1905, p. 582.

463 A. H. F. J. Nusselein, 'Beschrijving van het landschap Pasir', ibid., p. 567.

464 Hageman, op. cit., p. 104.

185 J. van Capellen, 'Brow: 1844'. (Kol., n.d.) 
merce with both Sultans on behalf of the British Government. The peoples of Boeloengan and Goenong Taboer, he found, were "extremely anxious to induce Englishmen to settle amongst them, offering ground to build houses upon, gratuitously". ${ }^{466}$ Belcher's treaties were not confirmed by Great Britain, ${ }^{467}$ but the fact that they had been signed at all was striking proof of the ineffectiveness of the Dutch system of contract-making without actual occupation. Less than two months before, both these Sultans had promised to have nothing more to do with any foreign power other than the Netherlands. ${ }^{468}$

These various moves on the East Coast coincided with Minister Baud's modification of the rules governing the activities of local Dutch officials. Baud, however, was no expansionist. Like van den Bosch, he believed that all available resources should be devoted to the exploitation of Java and Sumatra. Many phrases in his 1843 instructions indicated that he was nervous lest a too sudden removal of the curb on activity in Borneo should encourage the Government of the Indies to plunge forward into a career of reckless imperialism. But by 1845 he had come to realize that Dutch sovereign rights in the island could not be upheld unless the authorities in Batavia were given greater freedom of action. "Borneo", he wrote - with Brooke and Murray very much in mind - "has become the point de mire of all kinds of speculative enterprises". ${ }^{488}$ In October 1845 he laid down three principles by which future policy was to be guided. All import and export duties were to be abolished, since smuggling prevented their being collected in any case, Christian missions were to be encouraged and the work of the missionaries identified as much as possible with the administration, ${ }^{470}$ and greater efforts were to be made to exploit Borneo's mineral wealth. ${ }^{471}$

The appointment of J. J. Rochussen as Governor-General of the

400 Belcher, op. cit., Vol. i, p. 234.

$\$ 07$ Copies may be found in F.O. 12/86.

468 Contemporary Dutch writers claimed that these treaties were extorted by Belcher under threat from the guns of the Samarang. The only authority for the incident is his own account, which naturally does not support this view.

400 Letter of October 28th, 1845, Semi-official. (Quoted by Colijn, Politiek beleid, Deel i, pp. 34-6).

470 Christian missionaries were not permitted to enter Borneo until 1836. The Dutch feared that they would be killed, and that expensive punitive expeditions would then have to be sent to avenge them. Two members of the Rheinische Missions Gesellschaft visited the Chinese districts of Sambas in 1838. (E. Doty and W. J. Pohlman, 'Tour in Borneo...', The Chinese Repository, Vol. viii, pp. 283-310).

471 Letter of October 28th, 1845. 
Indies earlier in the same year made it certain that these new instructions would be acted on with alacrity. Possession in name only, Rochussen believed, was a totally inadequate guarantee of future Dutch sovereignty over the Outer Possessions. He hoped to extend his Government's rule from one end of the Archipelago to the other, and was ready to use force if necessary to achieve his purpose. "He who is sparing at seedtime", he said, "cannot expect to reap a rich harvest". ${ }^{472}$

After conferring with Commissioner Weddik, Rochussen suggested to Baud that the existing administrative structure in Borneo should be reorganized in order to give it greater cohesion and permanence. His proposals were accepted, and in December 1845 he was given authority to place the various establishments in the island under unified control. Permission was also granted for the appointment of a 'Governor of Borneo and Dependencies'. ${ }^{473}$ The public announcement of these changes declared that they were prompted by a desire on the part of Government to improve the efficiency of the Borneo administration and to promote the "moral and religious civilization" of the population. ${ }^{474}$ But the text of the Cabinet decision authorizing them shows that they were primarily intended to impress foreign nations, particularly Great Britain. The creation of a Government of Borneo, it was hoped, would not only emphasize that the greater part of the island was Dutch territory, but would also remove the stigma attaching to such titles as 'Resident of the West Coast', and 'Resident of the South and East Coast', by which the heads of the local administration were currently known, and which implied - with embarrassing accuracy - that Dutch rule did not extend into the interior. ${ }^{475}$ The new arrangements came into force in February 1846. Commissioner Weddik became the first Governor, and it was announced that the capital of Borneo would be at Sintang, more than three hundred miles up the River Kapoeas in the western part of the island. ${ }^{476}$

During the next four years an effort was made to extend Dutch influence to the remoter areas. In April $1846 \mathrm{H}$. von Dewall was

472 Quoted by H. Colijn, Neerlands Indië, Deel ii, p. 13.

473 Minister of the Colonies to the Governor-General, December 19th, 1845. (Kol., 1845 , No. $443 / Q^{1}$, Very Secret).

474 Besluit of February 28th, 1846. The text of the preamble of this decree may be found in C. J. Temminck, Coup-d'œil général sur les possessions néerlandaises daons l'Inde archipélagique, Vol. ii, p. 150.

475 Kabinetsbeschikking of December 17th, 1845, L* H/44, Very Secret.

476 Besluit of February 28th, 1846. Minister of the Colonies to the King, May 12th, 1846. (Kol., 1846, No. 133, Secret). 
appointed gezaghebber (administrator) of the East Coast, with headquarters at Koetei, ${ }^{477}$ and the formidable task of confirming the many states scattered along the eight hundred miles of coastline entrusted to his care in their allegiance to the ruling power. By the end of 1850 , with assistance from Resident Gallois of Bandjermasin, he had negotiated new contracts with every ruler of importance in the area. ${ }^{478}$

In March of the same year the northern limit of the territory claimed by the Dutch was fixed at $40^{\circ} 20^{\prime}$ North Latitude. ${ }^{478}$ A short time before a proposal had been put forward that the boundary should be extended to $6^{\circ} 25^{\prime}$ North, approximately the area of Sugut River, which enters the sea fifty miles north-west of Sandakan, the future capital of North Borneo. The scheme came to nothing, however, chiefly because the extra stretch of coastline which would be gained was not thought sufficiently productive to warrant the expense of suppressing the pirates who inhabited it. ${ }^{480}$

On the West Coast the energies of the Dutch administration were chiefly taken up in safeguarding Sambas and the Upper Kapoeas basin against encroachments from Sarawak. Raja Brooke was known to be corresponding with the Panembahan of Sanggau and other native rulers in Dutch Borneo with a view to increasing the existing frontier trade, and raids by Sarawak Dyaks against the Dyaks of Sambas were common. ${ }^{481}$ In the opinion of one Dutch official, it was only because the Netherlands Government controlled the mouth of the Kapoeas (and, consequently, the traffic which moved up and down this 'great canal', as it was called, of western Borneo) that the princes of the interior did not go over to the White Raja en bloc. ${ }^{482}$ To provide a counter-weight, therefore, to the prestige which Brooke had won for himself on both sides of the border, the Assistant-Residents of Pontianak and Sambas

477 Besluit of April 24th, 1846, No. 3.

478 J. G. A. Gallois, 'Korte aanteekeningen, gehouden gedurende eene reis langs de Oostkust van Borneo..., BTLV, 1856, pp. 221-63. Hageman, op. cit., pp. $76,82,86,100,105-6$. Nusselein, op. cit., p. 567. Knappert, op. cit., p. 582.

479 Kabinetsbeschikking of March 15th, 1850, $\mathrm{L}^{\mathrm{a}} \mathrm{G}^{5}$. (Kol., 1850, No. 84/G, Very Secret).

480 Rapport by A. Weddik, February 1850. (Buit. Zaken, No. 3134). H. von Dewall, 'Aanteekeningen omtrent de Noordoostkust van Borneo', TTLV, Deel iv (1855), pp. 423-58.

481 Brooke to the Panembahan of Sanggau, April 2nd, 1845, Assistant-Resident of Pontianak to the Governor-General, August 14th, 1846, No. 29, and September 5th, 1846, No. 37, Secret. (Kol., 1847, No. 49, Secret).

482 Rapport of Lieut. O. van Kessel, quoted in Assistant-Resident of Pontianak to the Governor-General, April 26th, 1847, No. 10/124, Secret. (Kol., 1847, No. 335, Secret). 
were sent on tour through their provinces during 1847 to 'show the flag', and to renew the oaths of allegiance of the native princes. ${ }^{483}$ The Netherlands Indian Government sought by these means to prevent the southward expansion of Raja Brooke's influence, and also to forestall any attempt by foreign nations or individuals to found settlements in imitation of his kingdom at Sarawak.

Confirming the allegiance of native princes, however, was something that could have been done just as well under the old administrative system, and the institution of a 'Government of Borneo and Dependencies' did not of itself help to increase Dutch prestige in the island. As a diplomatic gesture, the new organization was put into effect too late to be of value, since by 1846 Great Britain had already rejected the Dutch interpretation of the Treaty of 1824 , and had reserved her right to found colonies in Borneo if the need arose. As a practical measure, adopted to achieve greater efficiency, it was equally unsuccessful. The selection of Sintang as the site for a capital, for example, was quite inappropriate. In 1846 the interior of Borneo was completely unknown. No white man had yet crossed the island from one side to the other in any direction. ${ }^{484}$ Yet the Home Government's plan for a centralized administration envisaged the construction of a network of roads and the linking of the principal rivers at their source by means of canals. ${ }^{485}$ A scheme involving such insuperable engineering problems would presumably never have been proposed had the Minister of the Colonies possessed an accurate knowledge of the geography of Borneo. GovernorGeneral Rochussen was better informed, and although he obeyed the order to set up a central capital, he pointed out that efficient overland communications could not be developed without immense expenditure, which, in the circumstances, he considered unwarrantable. ${ }^{488}$ Sintang did not in fact function as an administrative headquarters for the whole island at any time. Weddik never took up permanent residence there, and in 1847, while still retaining his official appointment as Governor

483 Besluit of April 20th, 1847, La W, Secret.

484 The German geologist, Heinrich von Gaffron, was the first to do so. Between December 1846 and January 1847 he crossed from Kota Waringin on the South Coast to Pontianak on the West. (See H. von Gaffron, 'Beschrijving van het westelijke gedeelte van de Zuid- en Oosterafdeeling van Borneo...', $B T L V, 1860$, pp. 243-346).

485 'Briefwisseling over de reorganisatie van het bestuur van Borneo'. (Kol., May 11 th, 1849, La A, No. 1).

188 Governor-General to the Minister of the Colonies, February 28th, 1846, No. 55, L" G. Secret. (Kol., 1846, No. 150/V, Secret). 
of Borneo, was sent on special duty as a commissioner to the Moluccas. ${ }^{487}$

By 1848 the authorities at The Hague had realized that the original plan to establish a centralized administration for Borneo had been a mistake. Accordingly, Rochussen was told to refrain from taking any action in the matter, at any rate for the time being. But now a fresh problem arose: How could the 'Government of Borneo' be abolished without creating a false impression of Dutch intentions? It would be impossible merely to return to the old system of coastal residencies, since that might well imply that Dutch sovereign rights in the interior of the island were being abandoned or modified. The Governor-General was therefore instructed to reorganize the Borneo administration a second time, but to do so in such a way that foreign nations would be given no indication of future plans, and no opportunity to draw inferences damaging to Dutch prestige from the titles of officials invested with the governing power. ${ }^{488}$

Rochussen solved the problem by dividing Dutch Borneo into two mutually independent administrative areas - the Westerafdeeling (Western Division) and the Zuid-en Oosterafdeeling (South and Eastern Division). By this expedient he removed the disadvantages of a single government and, at the same time, through the selection of appropriate titles, laid emphasis on Dutch claims to sovereignty over the interior as well as over the coasts. There was already a Resident at Bandjermasin, who took charge of the new South and Eastern Division, and a Resident was now appointed for the Western Division in place of the former Assistant-Residents of Pontianak and Sambas. The office of Governor of Borneo, however, was to remain unfilled "until such time as the condition of the country and of the inhabitants renders a central establishment for this official both possible and necessary". ${ }^{489}$ Meanwhile, in Holland, the 'Constitutional Revision' of 1848 had been peacefully carried through. The violence of the February riots in Paris and the possibility of similar outbreaks spreading to the Netherlands, coupled with the threat of interference in the country's domestic affairs from revolutionary governments springing up around it, converted King William II, as he himself said, from a diehard to a revolutionary overnight. In November he consented to a new Funda-

487 See W. R. baron van Hoëvell, 'Onze roeping op Borneo', TvNI, 1825, ii, p. 193.

488 Kabinetsmissive of September 9th, 1848, No. 247, L" Y/1, Secret. (Kol.)

489 Besluit of August 27th, 1849, No. 8. (Stb., 1849, No. 40). No 'Government of Borneo' was reconstituted until July 1st, 1938. 
mental Law (Grondwet) for the Kingdom of the Netherlands, drafted largely under the influence of the Liberal leader, Thorbecke. ${ }^{400}$ Direct voting was introduced and the franchise extended, restrictions on freedom of speech and assembly were relaxed, and the States-General were given a greater measure of control over public finance, including the colonial revenues.

The 'Year of Revolutions' in Europe also marked a turning-point in the history of Anglo-Dutch rivalry in Borneo. Because of the uncertainty of the general political situation, Dutch statesmen after 1848 felt obliged to be more careful than their predecessors to ensure that disputes over Far Eastern affairs did not cause friction between Great Britain and the Netherlands at home. "When I take into consideration the present state of affairs", wrote the Dutch ambassador in London in June 1849, "and how important it is just now for our country to maintain friendly relations with our English neighbours, then it seems to me to be of the utmost importance that the prevailing atmosphere of goodwill should in no circumstances be disturbed. ${ }^{401}$ The policy instigated by Baud in 1845 of trying to halt British expansion in Borneo by making formal diplomatic protests to Her Majesty's Government in London was therefore abruptly abandoned. Early in 1849 when a copy of the British treaty of May 1847 with Brunei found its way to The Hague, the Dutch Government remained silent, even though in accordance with one of the provisions of this treaty the Sultan of Brunei had promised never to grant territory to a foreign power without British consent, thus submitting to a degree of British control over his dominions which it had been a prime purpose of Dutch diplomacy during the preceding four years to prevent. In March 1850 the. Dutch Cabinet came to the reluctant conclusion that the Government of the Netherlands "must acquiesce in the actions of Great Britain on the north-west coast of Borneo". 482

Within the island itself Dutch policy also underwent a minor revolution at this time. The period immediately following the accession of the Liberals to power in Holland saw a steady strengthening of opposition to the Culture System and to the methods of compulsion upon which it was based. It was true that not even the Liberals were yet prepared to set aside the long-established principle that colonies existed

400 P. J. Blok, History of the People of the Netherlands, Vol. v, pp. 457-61.

401 Schimmelpenninck to Lightenveldt, June 22nd, 1849, No. 107. (Buit. Zaken, No. 3134).

492 Kabinetsbeschikking of March 15th, 1850, Ln G5, Very Secret. (Kol., 1850, No. 84/T, Very Secret). 
solely for the benefit of the mother country, but many among them, notably Wolter Robert Baron van Hoëvell, believed that the existing system pressed upon the inhabitants of the Indies with unnecessary severity. The Culture System had not been applied in Borneo, but van Hoëvell was critical of Government policy there also, declaring that direct Dutch rule ought to be substituted without delay for the extortionate tyranny of the Malay princes. The Chinese of the West Coast he regarded as useful, if fractious, colonists, but he could find nothing good to say about the Malays. They were "an evil and shiftless people ... lazy, morally and physically corrupt, slaves to idleness and gambling, intolerant and fanatical". Raja Brooke had demonstrated in Sarawak what could be done to check them, and so alleviate the misery of the aboriginal Dyaks, but the Netherlands Indian Government had thus far made no attempt to follow his example. "We must thank God as men and Christians", wrote van Hoëvell, "that others have undertaken what we ourselves should properly be doing". ${ }^{493}$

Several years were to pass before any progress was made towards placing Dutch Borneo under direct rule, but in the meantime the claims of those who wished to see the Outer Possessions thrown open to private enterprise had begun to receive attention. In August 1848 the Minister of the Colonies, J. C. Rijk, declared that the underdeveloped parts of the Indies would never become worthwhile economic assets until the Dutch commercial world was given free access to them. The Colonial Government by itself would be quite unable to supply the capital needed to bring them into full production, since its finances had to bear heavy annual burdens on behalf of the motherland. Experience had shown, moreover, that governments were not as a rule successful in organizing industrial or commercial undertakings, which were "in all respects better entrusted to the control and interest of private persons". ${ }^{84}$ Shortly afterwards a Government-inspired article appeared in the Nieuzve Rotterdamsche Courant giving particulars of certain iron-ore deposits discovered not long before in the district of Tanah Laoet, in south-eastern Bandjermasin. This article prompted the firm of Daehne \& Co, of The Hague, to apply for a mining concession, and their request was forwarded to Batavia for consideration. ${ }^{485}$

Governor-General Rochussen, however, was not in favour of the

493 Baron van Hoëvell, 'Onze roeping op Borneo', pp. 187 and 191. (Quoting words used by himself in 1848).

404 Minister of the Colonies to the King, August 22nd, 1848, L' A, No. 1.

605 Department of Colonies to the Governor-General, November 8th, 1848, No. $1 / 653$. 
development of the Outer Possessions by private enterprise. He had already investigated the possibility of exploiting the iron of Tanah Laoet, and had decided against starting a Government mine there when his experts told him that the ore could not be raised cheaply enough to compete with imports from Europe. ${ }^{486}$ The whole area was wild and uncivilized, he told the authorities in The Hague, and it would be foolish to allow a private firm to operate there. If, after learning all the facts, Daehne \& Co still wished to take up a concession, they would have to assume full responsibility should disaster overtake them. The Government of the Indies would be unable to offer them any special protection, and could not assist them to obtain labour or transport. ${ }^{407}$ These hard truths were communicated to Daehne \& Co, who thereupon took no further interest in iron-mining in Borneo. ${ }^{488}$

Rochussen's attitude to private speculators may be compared to Raja Brooke's. Both believed that the commercial penetration of the Indies by European capitalists would have to be carefully controlled, or it would lead to endless conflicts and disturbances. But whereas Brooke's main concern was to prevent undesirable Europeans from corrupting his beloved Dyaks, Rochussen opposed the influx of capitalists on different grounds. In his opinion private individuals should not be encouraged to enter a field which properly belonged to the Netherlands Indian Government alone. That Government must first establish effective rule in the Outer Possessions. Not until then would it be wise to call on the ondernemingsgeest of the Dutch nation to develop these barbarous areas.

The Governor-General's views were not welcome in official circles in The Hague, where support for the principle of development through private enterprise continued to prevail. In February 1850 C. F. Pahud, the new Colonial Minister, ${ }^{480}$ appointed a special commission to inquire into "the tin-mines of Banka in particular and mining in the Netherlands Indies in general". ${ }^{000}$ Presenting its findings at the end of July, this commission reported that it had been unable to agree on the question of Banka tin, but that its unanimous opinion was that the 496 Besluit of March 30th, 1847, No. 13.

497 Governor-General to the Department of Colonies, June 17th, 1849, No. 306/6, Semi-official.

498 Department of Colonies to Daehne \& Co, January 17th, 1850, No. 5/46. Cf. R. Broersma, Handel en bedrijf in Zuid-en Oost-Borneo, Chap. I.

489 Four Colonial Ministers succeeded one another in quick succession during 1848-9. J. C. Baud was followed by J. C. Rijk, G. L. Baud, E. B. van den Bosch, and C. F. Pahud in that order.

500 Koninklijk Besluit of February 25th, No. 26. 
exploitation of all other minerals should be left to private enterprise, and that Government mines already operating in the Indies should be turned over to entrepreneurs. ${ }^{501}$ Pahud accepted these recommendations, and the following October announced that Dutch firms would henceforward be granted free access to the mineral wealth of all parts of the Indian Archipelago except Java and Banka. ${ }^{502}$

The way was now clear, at least in theory, for the exploitation of Dutch Borneo by private mining companies. Pahud's announcement was followed in June 1852 by the inauguration of a Government Mining Service, ${ }^{503}$ whose geologists were soon submitting lengthy reports on the mineral resources of the Indies. These were published in the newlyfounded Natuurkundig Tijdschrift voor Nederlandsch-Indië, ${ }^{504}$ and could therefore easily be consulted by firms contemplating investment in the Outer Possessions. Previously, most reports of scientific discoveries made by colonial servants had been filed away in the archives at Batavia, unread save by officials of the Government of the Indies. Despite a great increase in public knowledge, however, private enterprise achieved very little in Dutch Borneo before the 1880's. The obstacles to be overcome deterred all but a few speculators, and these few met with little success.

The nature of the difficulties encountered both by Government and private concerns is well illustrated by the case of coal-mining in the South and Eastern Division. The motives which prompted the Dutch to mine coal in the Indies were similar to those which led the British to interest themselves in Brunei and Labuan. Indeed, if anything, the Dutch had a better reason than their rivals to fear being cut off from European supplies in time of war, since their Navy, unlike the British, did not hold command of the sea. The increasing use of steamers, the mechanization of the sugar industry in Java and, later, the development of railways, made it all the more desirable to have a reliable local supply of coal. ${ }^{\text {sos }}$

Four Government mines were brought into production in the South and Eastern Division at various times between 1846 and 1888. These

501 'Rapport der speciale kommissie ...', July 24th, 1850. (The text is in NTvNI, 1851, pp. 80-107).

502 Koninklijk Besluit of October 24th, 1850, No. 45. 'Verslag van het beheer... over het jaar 1851', Staatscourant, Bijhlad, 1853-4, III, xxxvi, 2, p. 278.

${ }^{603}$ Besluit of June 3rd, 1852, No. 5. (Stb., 1852, No. 37).

504 This journal was published at Batavia from 1851 onwards by the Natuurkundige Vereeniging in Nederlandsch-Indië. It was edited by Dr. P. Bleeker.

506 Alex L. Ter Braake, Mining in the Netherlands Indies, p. 59. 
were the Hoop (1846-8) on the River Riam Kiwa, east of Bandjermasin, the Oranje-Nassau (1848-84) and its subsidiary, the Assahan (1872-81), near Pengaron, and the Pelarang (1861-8) near Samarinda in Koetei. ${ }^{508}$ The first and last-named were of slight importance, but the Oranje-Nassau and the Assahan between them produced roughly 300,000 tons of coal in thirty-six years. ${ }^{507}$ The only private mine of consequence was the Julia Hermina (1856-9), which was located ten miles south-west of Martapoera, and belonged to the 'N.V. tot bevordering van mijnontginning in N.I.'.508

Hopes were high in the 1850's that the exploitation of the coal resources of Borneo would quickly free the Netherlands Indies from dependence on foreign supplies. For a time this confidence seemed to be justified - from 1854 to 1858 all Government requirements of 'steam-coal' were met by the output of Pengaron alone ${ }^{500}$ - but in the long run neither Government nor private mines fulfilled expectations. A protracted wrangle among the experts about whether Borneo coal was 'black' or 'brown' did its reputation much harm, and caused Dutch shipping and commercial firms to be chary of using it. ${ }^{510}$ High transportation costs, a shortage of skilled workmen, the unsuitability of the local timber for pit-props, outbreaks of sickness among the miners, and persistent flooding in the underground shafts all added to the production difficulties. ${ }^{.11}$ It was soon discovered that Borneo coal could not be marketed in Java cheaply enough to compete with coal imported from abroad.

Many of these difficulties might have been overcome had the local Malay rulers been willing to co-operate with the Dutch Government.

$506 \mathrm{C}$. de Groot, 'Bijdragen tot de geologische en mineralogische kennis van... Zuid- en Oosterafdeeling van Borneo', NTvNI, 1857, pp. 3-30. Theodor Posewitz, Bonneo: its Geology and Mineral Resources, p. 461.

507 Broersma, op. cit., p. 69. Posewitz (op. cit., p. 467) gives 241,770 tons. Exact figures are difficult to calculate because in some years 'slag' was included in the official totals of the coal mined.

508 'Verslag van het beheer ... over 1856', Staatscourant, Bijblad, 1858-59, II, lxv, p. 695. 'Maatschappij tot bevordering van mijnontginning in NederlandschIndië', $T v N I, 1856, \mathrm{i}$, pp. 312-13.

500 C. de Groot, op. cit., p. 30.

510 See the articles by C. de Groot and S. Bleekrode in TvNI, 1850, ii, pp. 201-4, and in $N T v N I, 1852$, pp. $341-2 ; 1859$, pp. $313-28 ; 1861$, pp. $29-41,370-7$; and 1868, pp. 69-148.

Posewitz (op. cit., p. 272) suggests that this dispute was largely caused by variations in the quality of coal from Bornean mines sent to the experts for analysis.

511 Posewitz, op. cit., p. 464. 
Unfortunately, however, the Sultan and pèngerans of Bandjermasin were opposed to the establishment of any mines, either Government or private, in their dominions. This was the more serious because the richest coal-bearing lands happened to be in the district of Martapoera, which was still under the Sultan's direct control. "It is much to be desired", wrote Rochussen in 1849, "that the coals lie on Government territory, and that Martapoera is part of that territory. Perhaps the uncertainty which surrounds the succession [to the throne of Bandjermasin] will provide an opportunity of bringing these districts under Government rule ... this must be left to the skill of the official standing at the head of the administration at the time". ${ }^{512}$

These remarks by the Governor-General were little more than an expression of hopes for the future of coal-mining in Bandjermasin, in which he had always taken a great personal interest. But they marked, nevertheless, the beginning of an entirely new trend in Dutch policy towards the island as a whole. Minister Baud had authorized a departure from the principle of abstention, but had not been in favour of using military means to further political ends. But now, from 1850 onwards, the Netherlands Indian Government began to use force in order to bring under direct rule those parts of Dutch Borneo which they had thus far failed to subdue. The areas which first felt the effects of this new policy of armed intervention were the Chinese districts of the Western Division. ${ }^{513}$

By 1850 the gold-mining kongsis of western Borneo had achieved

512 Quoted by E. B. Kielstra, 'Het Sultanaat van Bandjermasin', De Indische Archipel, pp. 241-2.

513 In the section which follows I have not attempted to provide a detailed military history of the 'kongsi-wars' of $1850-4$, since to do so would involve an excursion into a subject outside the scope of the present study. My purpose has rather been to analyse the political motives behind the military events.

Comprehensive accounts of the various Dutch expeditions during this period are to be found in $\mathrm{E}$. B. Kielstra, 'Bijdragen tot de geschiedenis van Borneo's Westerafdeeling', De Indische Gids, 1889-90, 1893-4; in W. A. van Rees, Montrado: geschied- en krijgskundige bijdrage betreffende de onderwerping der Chinezen op Borneo; and in 'De verwikkelingen van het NederlandschIndisch Gouvernement met de Chinesche bevolking op Westelijk Borneo toegelicht', TvNI, 1853, ii, pp. 273-410. A useful modern summary is P. M. van Meeteren Brouwer, 'De geschiedenis der Chineesche districten der Westerafdeeling van Borneo van 1740-1926', De Indische Gids, 1927, ii, pp. 1057-1100. J. W. Young, 'Bijdrage tot de geschiedenis van Borneo's Westerafdeeling', $T T L V, 1895$, pp. 499-550, supplements and corrects Kielstra's account.

Descriptions of the social life and organization of the kongsis are contained in J. J. M. de Groot, Het kongsizerezen van Borneo (referring to the kongsi Lan Fang of Mandor) and in S. H. Schaank, 'De kongsis van Montrado', $T T L V, 1893$, pp. $498-612$ (referring to the kongsis of Sambas). 
complete de facto independence. They were living under their own laws, levying their own taxes, and punishing criminals according to their own ideas of justice. They regarded the Sultan of Sambas as merely the ruler of a neighbouring state, and flouted his attempts to exert authority over them. An annual poll-tax which they paid to the Dutch Government was considered by them to be simply a 'present' offered by one sovereign power to another. In any case, the sum involved was quite insignificant $-f .5,600$ a year, which represented only 20 doits per head of the Chinese population of Sambas. ${ }^{514}$

The most powerful of the kongsis was the Ta Kang ('Great Port' or 'Creek'), ${ }^{515}$ which dominated the Montrado-Larah area, in the centre of the gold-fields. South of Montrado lay the lands of the kongsi Lan Fang ('Fragrant Flowers Association'), ${ }^{\mathbf{1 1 6}}$ with headquarters at Mandor. and to the north, in the general area of Sepang, Seminis, and Pemangkat, were the lands of the San T'iao Kou ('Three-Branch Watercourse'). ${ }^{517}$ All three kongsis ${ }^{518}$ were bitterly hostile to one another. and in 1837 there had been pitched battles in the gold-fields. ${ }^{510}$ The basic cause of this rivalry was the increasing exhaustion of the Sambas mines. By the mid-nineteenth century many of them had been worked out, and a fierce struggle was in progress for control of the remainder. Pressure exerted by the Ta Kang on the San T'iao Kou had already caused substantial emigration to Sarawak, and miners in all districts were beginning to abandon gold-digging in favour of agriculture. ${ }^{\mathbf{5 2 0}}$

A considerable trade had grown up through the years between the Chinese of western Borneo and Singapore. Some of this trade was legitimate, but smuggling was very prevalent. Three commodities in particular were imported illegally: salt, which was a Government monopoly, and therefore expensive; opium, which was farmed by the Pĕngeran Ratu of Sambas at a handsome profit; and gunpowder, which was a prohibited article. The smugglers either brought their goods over the border from Sarawak or sailed them up unguarded rivers and creeks on the Sambas coast.

514 Report by the Assistant-Resident of Sambas, August 25th, 1848. (TvNI, 1853, i, pp. 191-2). 120 doits equal one guilder.

516 Contemporary Dutch romanizations: Tai Kong, Taykong.

516 Contemporary Dutch: Lanfon, Lanfong.

517 Samthiaokeoe, Sam tiankeo, Sam-thiao-keeuw.

618 Smaller kongsis were established at Boedoek and Loemar, but these were under Ta Kang control.

510 Schaank, op. cit., pp. 547-9.

$620 \mathrm{Cf}$. Jacob Ozinga, De economische ontwikkeling der Wester-afdeeling van Borneo, pp. 220-2. 
Both the Malay and Dutch authorities in western Borneo felt they had good reason to resent the independent attitude assumed by the Chinese of the interior. It was well known that the gold-miners made up by far the richest section of the population - the Perngeran Ratu of Sambas told Assistant-Resident van Kervel that the mining kongsis produced approximately 80,000 taels of gold a year - yet they contributed little or nothing to the state revenues. Dutch officials sent to Montrado and emissaries from the Sultan of Sambas were treated by the Chinese headmen with disdain. The Malay princes were particularly annoyed at having to deal circumspectly with the kongsis because this lowered them in the estimation of their own subjects. They felt both humiliated and impotent, and consequently looked to the Government of the Netherlands Indies for support against the foreign barbarians established in their midst. ${ }^{\text {.21 }}$

The first indication that the Dutch were about to take a sterner line with the kongsis came at the beginning of 1850. In February of that year a prahu carrying contraband opium, salt, and gunpowder from Singapore discharged its cargo at a factory belonging to the kongsi Ta Kang at the mouth of the Sedauw River. Following a protest from the Malay opium farmer at Sambas, Assistant-Resident R. C. van Prehn Wiese demanded the surrender of both vessel and cargo. The kongsi headmen refused to obey, and prepared to defend the prahu by erecting a stockade around it. Van Prehn Wiese then suggested to the Resident of the Western Division, T. J. Willer, that the offending vessel should be seized by force. Willer replied that there were not enough Government troops available on the West Coast at the moment for operations of this kind, but he declared a blockade of the river and told the kongsi headmen to send the captain of the prahu and ten members of its crew to Sambas for trial. This order was repeated twice, but no heed was paid to it by the rulers of the Ta Kang. ${ }^{522}$

Meanwhile Willer had applied to Batavia for military support. In April Governor-General Rochussen ordered the frigate, Rijn, which was about to sail for China, to call at the West Coast in order to make a demonstration of force. ${ }^{523}$ Soon after this vessel reached Pontianak an argument developed between her captain and Resident Willer about the best way to employ her services. Due partly to this controversy,

621 Report of the Assistant-Resident of Sambas, August 25th, 1848.

522 Van Meeteren Brouwer, op. cit., pp. 1076-7.

523 Besluit of April 17th, 1850, No. 9. 
and partly to the cowardly behaviour of some auxiliaries supplied by the Sultan of Sambas, an attack on the stockade in the Sedauw River failed ignominiously, and the captain of the Rijn, much to the Resident's disgust, sailed his ship away to China.

Heartened by this defensive success, the rulers of the Ta Kang decided to drive the Dutch right out of Sambas. To do so, their troops had to cross the lands of the San T'iao Kou, which consequently allied itself with the Government in the hope that its gold-mines, long coveted by the Ta Kang, would thereby be protected. By the end of August, however, Ta Kang troops had captured all the districts belonging to the San T'iao Kou including Pemangkat, the seaport which controlled the approaches to Sambas.

While these operations were in progress, the Dutch Government reinforced their West Coast garrisons with two companies of infantry and a detachment of artillery under the command of Lieutenant-Colonel Sorg. Early in September Sorg met the Chinese in a fierce battle before Pemangkat and won the day, though he himself received a wound from which he later died. The officer sent to take over his command, Lieutenant-Colonel le Bron de Vexela, was instructed to safeguard the coastal areas against Chinese attack and to blockade the rivers, but not to become entangled with the enemy in the interior. A minor engagement took place near Pemangkat in October, but the wet monsoon set in soon afterwards, and le Bron withdrew the bulk of his troops to Sambas. ${ }^{524}$

The kongsi Ta Kang had no cause to be dissatisfied with its military achievements to date, nor to be apprehensive about the future. A delegation from this kongsi, however, arrived unexpectedly at Pontianak at the end of December and made an act of unconditional surrender before Resident Willer. ${ }^{525}$ A provisional agreement was drawn up, whereby the kongsi promised to pay an indemnity and an annual tax in gold, to refrain from seditious activities, and to submit to Government control over its domestic affairs. Three Chinese accompanied the Resident to Batavia early the following year to obtain the GovernorGeneral's approval of the new arrangements. ${ }^{526}$

This seemingly unnecessary 'kotow' on the part of the Chinese had its origin in the internal politics of the Ta Kang. Some members of

524 Van Meeteren Brouwer, op. cit., pp. 1077-9.

-25 Javaasche Courant, January 22nd, 1851.

528 'Politiek verslag over 1851 : Westerafdeeling van Borneo'. (Kol., 1853, No. 225, Secret). 
this kongsi were in favour of combining all the mining communities in Sambas in a federation ${ }^{827}$ under Dutch protection. Others, especially those who belonged to the secret brotherhood of the San Tien Hui ('Three Dots Society'), ${ }^{528}$ preferred a policy of armed resistance to the Netherlands Government. The first group was made up of the traditional leaders of the kongsi, men of substance, who had most to lose in an unsuccessful struggle against the Dutch, while the second was drawn from the ranks of the under-privileged, ${ }^{\mathbf{5 2 9}}$ who saw a chance of seizing control in the confusion created by a war. The delegation which went with Willer to Batavia represented the 'peace at any price' party among the Ta Kang leaders.

The decision which now faced Rochussen - whether to accept the submission of the Chinese or not - was not an easy one to make. In the first place, he was greatly embarrassed by lack of precise information about the real state of affairs in the Borneo mining districts. Such knowledge as existed in Batavia on the subject was derived almost exclusively from Malay sources. "So long as the kongsis ruled the Chinese districts", wrote Resident Willer in August 1851, "they evaded all direct contact with European officials ... We do not know the Chinese, nor their affairs, and they do not know us, nor our principles and motives. The Sambas Court and the Chinese know one another much better, and draw profit from this circumstance to our disadvantage" ${ }^{530}$ No Dutch official at this time could speak any of the dialects of Chinese used by the miners, ${ }^{\mathbf{5 s 1}}$ and very few had ever visited the gold-fields. Secondly, Rochussen had to consider his Government's obligations to the Sultan of Sambas, and also to the Dyak population, many of whom were suffering greatly under the burden of exactions imposed on them by the kongsis. Thirdly, the Chinese of

627 The Ta Kang was itself a federation, and had grown to its present dominant position by absorbing smaller kongsis. The original union of Montrado kongsis, the Ho Shun ('Harmonious Agreement'), dating from 1776, was by 1850 synonymous with the Ta Kang.

528 Or 'Sam Tiam Foei'. Also known as the 'League of the Three Fingers'.

529 Only those members of a kongsi who held at least one share in the exploitation of its mines were entitled to vote at its assemblies, and only those born in China were eligible for office. (Schaank, op. cit., p. 575. J. J. M. de Groot, op. cit., p. 17). Rivalry between various Chinese secret societies was responsible for much of the internal strife which developed within the kongsis in their later years.

630 Letter of the Resident of the Western Division, August 22nd, 1851, No. 22, Secret.

531 J. J. Rochussen, Toelichting en verdediging van eenige daden van mijn bestuur in Indië, p. 40. 
Borneo were, at least in theory, subjects of the Government of the Netherlands Indies already, and amenable to its laws. Strictly speaking, the negotiation of treaties with them was out of place. Any regulation of their affairs ought properly to be effected by decree or proclamation, not by bargains negotiated between equal parties. Fourthly, the rights of the defeated kongsi San T'iao Kou had to be borne in mind. By the beginning of 1851 nine-tenths of the members of this kongsi had migrated to Sarawak in order to escape the ravages of the Ta Kang. It would obviously be unjust to the remainder if the rebel Chinese were permitted to absorb their lands, since the San T'iao Kou had been the only kongsi (apart from the neutral Lan Fang) which had not taken up arms against the Government. On the other hand, if these considerations made it desirable that the Government's will should be imposed by force, it was difficult to see where the necessary troops would come from. Dutch military resources in the Indies were already strained through having to deal with recent revolts in Palembang, Banka, and Bantam. As yet, moreover, no plans whatever had been worked out to provide for the eventual administration of the Chinese districts if and when the kongsis were brought into subjection.

After examining the provisional agreement arranged by Resident Willer with the Ta Kang delegation, Rochussen came to the conclusion that it could not be approved. Insufficient care had been taken of the rights and interests of the Sultan of Sambas, of the loyal kongsi San T'iao Kou, and of the Dyaks at present living under Chinese rule. ${ }^{532}$ He accepted in principle, however, the plan to disband the rebel kongsis, and sent Willer back to Pontianak to enter into further negotiations with the Chinese leaders. ${ }^{533}$ On arrival Willer found that within the Ta Kang the peace party seemed to be firmly in control, and he appointed one of its most influential members, Chêng Hung, ${ }^{634}$ as kaptai ('Regent') over the districts of the $\mathrm{Ta}$ Kang and its subordinate kongsis. ${ }^{\text {sss }}$ The Sultan of Sambas signified agreement with these arrangements, and Willer set off once more for Batavia to obtain fresh instructions.

Meanwhile Mr. A. J. Duymaer van Twist had replaced Rochussen as Governor-General of the Netherlands Indies. Having no immediate knowledge of Bornean affairs himself, van Twist was obliged to base 532 Ibid., pp. 49-50.

633 Besluit of March 27th, 1851, L' H, Secret.

634 Tjang-pin, Tjang Ping, Tjhiang-Fen, etc.

$\$ 85$ Governor-General to the Minister of the Colonies, August 22nd, 1851, No. 16, $L^{*} F^{1}$, Secret. (Kol., 1851, No. 281/M, Secret). 
his judgments and policies on the advice given him by his official counsellers in Batavia. One of these was Major-General Penning Nieuwland, who in the previous year had unsuccessfully tried to persuade Rochussen to order the forcible suppression of the kongsis without further delay, on the grounds that they were "a mutinous rabble from foreign parts". ${ }^{536} \mathrm{He}$ now gave similar advice to Rochussen's successor, but van Twist was not yet convinced that a military expedition was necessary, and from September 1851 to February 1852 Resident Willer had to wait at Batavia to learn the new GovernorGeneral's pleasure. At last approval was given for the setting-up of an administrative structure essentially similar to the one organized by Willer the previous year. For the time being no further military action was to be taken against the insurgents, and the coastal blockade was to be lifted. Regulations were drawn up governing taxation, and provision made for the more effective protection of the Malays and Dyaks living in the Chinese districts. Chêng Hung was confirmed in his appointment as Regent, and the Ta Kang was to be allowed to retain a large measure of control over its own domestic affairs. ${ }^{537}$

Returning to the West Coast at the end of March, Willer began the task of disbanding the mining kongsis. It soon became apparent, however, that the majority of the Chinese of Montrado were bitterly opposed to the idea of losing their traditional customs and system of administration. They announced that they were unwilling to abide by the agreements made on their behalf by Cheng Hung and the 'peace party' who had now clearly become unrepresentative of opinion in the Ta Kang as a whole. During the remainder of the year Willer tried repeatedly to persuade the Montrado Chinese to agree to the Government's proposals, but as the months went by it seemed increasingly likely that a new order could be established in western Borneo only by force of arms.

In February $1853 \mathrm{Mr}$. A. Prins, the General Secretary to Government at Batavia, was sent to the West Coast as a special commissioner with instructions to break the deadlock. ${ }^{538}$ His orders were to arrange matters peacefully if possible, but to be careful to act only by proclamation and decree; no more contracts or agreements were to be

506 E. B. Kielstra, 'Biidragen tot de geschiedenis van Borneo's Westerafdeeling', De Indische Gids, 1889, i, p. 350. 'Borneo en de heer Rochussen', TvNI, 1854, i, p. 29.

537 Besluit of February 16th, 1852, No. 1 (Kol., 1853, No. 41/E, Secret).

538 Besluit of December 29th, 1852.

539 Besluit of January 31st, 1853, $L^{\wedge} \mathrm{H}$, Secret. 
negotiated with any of the kongsi leaders; and the rights of the Sultan of Sambas were to be safeguarded in any arrangements made. ${ }^{539}$ At this time the military commandant of the Western Division was a Major Andresen, who had replaced le Bron de Vexela at the beginning of 1851. Since taking up his appointment Andresen had been sending a series of reports to Batavia expressing strong disapproval of the Chinese policy of Resident Willer. His view was that the plan to abolish kongsi rule entirely was a mistake, because a high level of production in the gold-fields could be maintained only if the existing administrative structure were kept in being. All would be well if the recalcitrant kongsis were given a sharp lesson. When, soon after arriving in Borneo, Commissioner Prins set out on an inspection tour of the gold-fields, it was Major Andresen who accompanied him, not Resident Willer, and before long Prins had been completely won over by his military adviser's arguments. In April the Ta Kang miners were formally declared to be in a state of rebellion against the Dutch Government. ${ }^{540}$ In May Willer was sent on 'leave' to Java, and when the Commissioner left Borneo himself a little later, Andresen was placed in charge of all political as well as military affairs in the Western Division. ${ }^{541}$ Finally, in July, all immigration into western Borneo from China was strictly prohibited. ${ }^{542}$

Meanwhile the number of attacks on isolated Dutch garrisons by bands of armed Chinese had been steadily increasing, and there seemed to be no chance whatever of a reconciliation being effected between the kongsis and the Government. Andresen therefore visited Batavia to seek the Governor-General's approval for a major punitive expedition. This was granted, but the approach of the wet monsoon caused the postponement of the campaign until the following year. When at last in May 1854 more than 2,000 troops arrived on the West Coast and began to invade the gold-fields, Chinese resistance collapsed abruptly. On June 2nd, as Government forces marched into Montrado in triumph, the kongsi headmen, clad in penitential white, knelt before them in the dust in token of submission. ${ }^{543}$

By this subservient behaviour the Montrado Chinese may have been hoping to gain through diplomacy the victory that had eluded them in

640 Approved by Besluit of July 8th, 1853, No. 14.

541 Assistant-Resident van Prehn Wiese took over the civil administration of the Division, but he had to follow Andresen's advice in all political matters. (Van Meeteren Brouwer, op. cit., p. 1083).

542 Publicatie of July 8th, 1853. (Stb., 1853, No. 56).

543 'Verslag van het beheer... over het jaar 1854', Staatscourant, Bijblad, 185657, II, xx, 2, p. 124. 
the field. If so, they were to be quickly disillusioned. The terms imposed by Andresen were designed to end once and for all the power of the Chinese of western Borneo to make war. His orders provided for the total dismemberment of the kongsi system of government, the demolition of all stockades and fortifications, and the confiscation of arms, ammunition, and all other property, including houses and mines. Dutch troops were stationed in the three principal kongsi-houses.

In November Commissioner Prins, who had meanwhile returned from Java, issued a 'provisional regulation for the civil administration of the newly-conquered Chinese territories'. From the former kongsi lands a new province was created, the 'Assistant-Residency of Montrado'. This was to be ruled directly by Dutch officials with the help and advice of approved Chinese headmen and of the Pĕngeran Tĕmĕnggong of Sambas. ${ }^{544}$ The task of rounding up rebel leaders and suppressing small outbreaks occupied the Dutch forces until the middle of 1856 , but all resistance was eventually crushed, and the administrative structure established by Prins (re-enacted by Government Decree in 1857) ${ }^{545}$ remained in force without substantial modification until the progressive decay of the gold-mines of western Borneo deprived the Chinese districts of their value and importance.

Some writers on the history of the mining kongsis have criticised the Netherlands Indian Government for its failure to support Resident Willer's Chinese policy in 1851-2. Had this been done, it is suggested, many of the subsequent difficulties might have been averted. ${ }^{546}$ It is certainly true that there was considerable vacillation on the part of the authorities in Batavia, and that an earlier decision one way or the other would have saved a good deal of fruitless negotiating with the Chinese. But it is by no means certain that the adoption of Willer's proposals would have solved the fundamental problem facing the Dutch, which was how peacefully to absorb into their administrative system an alien society, divided against itself and already in process of decay. By supporting Chêng Hung and the Ho Shun, Willer was protecting one section of this society, the magnates, against another, the under-

544 Provisioneel reglement of November 3rd, 1854, later confirmed by Besluit of March 12th, 1855. The kongsi Lan Fang was excepted from these provisions. It retained a measure of independence until 1884 when, on the death of kaptai Lin Ah Sin, it was absorbed into the Dutch administration.

545 Besluit of June 25th, 1857, No. 25. (Stb., 1857, No. 67).

${ }^{546}$ See, for example, E. B. Kielstra, De vestiging van het Nederlandsch geasag in den Indischen Archipel, p. 181, and van Meeteren Brouwer, op. cit., pp. 1081 and 1083. 
privileged - a policy which must surely have led to an explosion sooner or later. It is not without significance that when Commissioner Prins first visited Borneo at the beginning of 1853 , Chêng Hung, the so-called 'Regent', was living at Sambas "in fear of his life". ${ }^{547}$

The plain fact was that some of the Chinese of the West Coast saw advantages in living under a European government while others did not. This being so, Dutch rule had to be imposed by force if it was to be imposed at all. It was ironical, nevertheless, that one of the chief reasons why Willer's suggestions were rejected in Batavia was the insistence of Governor-General Rochussen on the need to safeguard the rights of the Sultan of Sambas. Two years later this same Sultan was deposed by van Twist for intriguing against the Government with the very Chinese against whom Rochussen had been trying to protect him. ${ }^{548}$ This is not to say that Rochussen's attitude was incorrect, for he had no choice in the matter. The Sultan's right to Dutch support was unquestioned, being based on formal contractual guarantee. All the Malay princes of Borneo with whom the Dutch had made treaties were entitled to similar protection against hostile elements in their own kingdoms. In return the Netherlands Indian Government had obtained certain reciprocal concessions, including the right to govern the succession to the throne, and this right it was now about to invoke, with far-reaching results, in the Sultanate of Bandjermasin.

By virtue of contracts negotiated between 1817 and 1826, the Dutch Government had acquired from Bandjermasin full sovereign powers over the greater part of the territory which later became the South and Eastern Division. The areas surrendered comprised the south-west and east coasts and certain provinces in the interior, none of which had actually been subject to the Sultanate when the contracts were signed, and over which the Dutch, at least until the 1840 's, exercised no more than nominal rule themselves. The lands of the Sultanate proper, however, which were the most populous and by far the most valuable part of the Division, had never been placed, even theoretically, under direct Dutch rule, and in 1849 were still being administered by the Sultan and his perngerans, acting as vassals of the Dutch Government. In that year, as we have seen, it had been suggested by J. J. Rochussen that these lands should be made gouvernementsgebied (direct rule territory),

${ }^{547}$ Kielstra, 'Bijdragen...', De Indische Gids, 1889, ii, p. 1148.

648 Van Meeteren Brouwer, op. cit., p. 1083. 
and opened to European commercial enterprise as soon as possible.

In 1852 the heir-apparent to the Sultanate of Bandjermasin died, leaving many sons, of whom two became serious contenders for the position of Sultan Muda. These were Tamjid Illah, born to the late heir by a Chinese woman, and Hidayat Ullah, a younger man than his rival, but the son of a princess. In accordance with local adat the latter was unquestionably the lawful heir. ${ }^{548}$ Pèngeran Tamjid, however, who was unpopular as well as being 'low-born', and saw that his only chance of ousting Hidayat was to curry favour with the Dutch, assured the Resident of Bandjermasin that he would grant everything the Government wanted if they, in turn, would support his candidature. On the Resident's advice the authorities at Batavia accepted these terms, and in June 1852 formally endorsed the appointment of Tamjid as the new Sultan Muda. ${ }^{550}$ When the strength of the opposition to him later became known, they regretted their choice, and recalled the official who had advised it, but did not reverse the original decision. ${ }^{551}$ Accordingly, when the death occurred in November 1857 of Sultan Adam, the reigning prince, Tamjid was immediately raised by the local Dutch administration to the throne, amid much popular discontent and in direct defiance of the deceased Sultan's will. The situation was further complicated by the appearance of a third pretender, Prabu Anom, who was an uncle of both Tamjid and Hidayat. Isolated disturbances and demonstrations followed, culminating at the beginning of 1859 in the general revolt known to historians of Indonesia as the 'Bandjermasin War'. ${ }^{552}$

The ensuing struggle caused considerable loss of life and immense damage to property in many parts of southern Borneo. Although by 1862 Dutch troops had won the upper hand, the 'state of war' in Bandjermasin did not end officially until 1867, and even then, peace was restored only in the coastal areas and in the lower basin of the Barito. Roving bands of insurgents, operating from strongholds in the interior, continued to harass the Government's forces for many years, and numerous punitive expeditions had to be sent against them before

540 E. B. Kielstra, 'De ondergang van het Bandjermasinsche rijk', De Indische Gids, 1890, ii, pp. 2396-7.

550 Besluit of June 10th, 1852, L* $C^{1}$, Secret.

551 Besluit of January, 14th, 1853, No. 3.

562 The chief authorities for the military history of the Bandjermasin War are: W. A. van Rees, De Bandjermasinsche krijg van 1859-1863, and H. G. J. L. Meyners, Bijdragen tot de kennis van het Bandjermasinsche rijk, 1863-1866. 
the last traces of the insurrection were finally stamped out at the beginning of the twentieth century. ${ }^{553}$

Nevertheless, the resort to arms had provided the Dutch with a convenient pretext for establishing the system of direct rule throughout the rebel territories. In June 1860 the Sultanate of Bandjermasin was declared to have 'lapsed', and the former Sultanate lands were placed under the control of Dutch Government officials. ${ }^{54}$ The suggestion put forward by Governor-General Rochussen eleven years previously had now been carried into effect, but the introduction of direct rule was not immediately followed by the economic prosperity he had envisaged. For one thing, the cost of the war and of its sequel left the Government without any money to spare for innovations or improvements and, for another, private speculators were understandably reluctant to invest in a country in which lives and property could not yet be properly safeguarded. A particularly cogent example of the disasters that might overtake the unwary speculator was provided by the case of the privately-owned Julia Hermina coal mine near Pengaron. Within a few days of the outbreak of the war, this mine was utterly destroyed by the rebels, and its European staff murdered to a man. Capitalists did not renew their interest in southern Borneo until the decade of the 1880 's. ${ }^{.55}$

The establishment of direct rule in Bandjermasin and in the Chinese districts of the West Coast brought to an end the sequence of events which had been set in train by the arrival of James Brooke in Sarawak in 1839. In order to meet the threat of foreign interference, the Government of the Netherlands Indies had been obliged to extend their effective rule to many areas which before the foundation of Sarawak had been entirely neglected. The Dutch had still to find a solution, however, to the more fundamental problem of how to derive profit from the lands they had absorbed, and in this their perplexity was shared by the British, who had thus far failed in their efforts to develop the resources of the northern part of the island.

553 E. B. Kielstra, 'De Bandjermasinsche Sultanspartij', Indisch Nederland, pp. 284-305.

554 Besluit of December 17th, 1859, La $\mathrm{K}^{3}$, Secret. Proclamation by Commissioner F. N. Nieuwenhuijzen, June 11 th, 1860.

655 Broersma, op. cit., p. 14. 


\section{CHAPTER IX}

\section{THE STATUS OF SARAWAK}

During the period from 1850 to 1870 , while the Dutch were strengthening their hold on western and southern Borneo, British interest in the island had been steadily declining. To some extent this was due to a change in the climate of opinion in Britain herself, for during these twenty years the influence of the Separatists and of the anti-imperialists of the Manchester School was at its height, and contemporary British statesmen were thinking more of getting rid of existing colonies than of acquiring new ones. Borneo had ceased to attract attention, moreover, because of the dismal failure of the settlement at Labuan, which seemed incapable of fulfilling any of the purposes for which it had been founded. With the example of Labuan before them, not even the staunchest supporters of colonial expansion could see any advantage in increasing Britain's imperial responsibilities elsewhere in Borneo.

Labuan had been founded, it will be remembered, for three main purposes: to serve as a coal-depot for British shipping, to provide a base for the suppression of Malay piracy, and to act as an entrepôt for the trade of the north-west coast.

As a coal-depot, the colony never lived up to expectations, despite the efforts of no less than four mining companies which carried on operations there and on the mainland at Muara (Brooketon) at various times between 1849 and 1880. These were the Eastern Archipelago Company (1849-58), the Labuan Coal Company (1860 - 5), the Amalgamated China Steamship and Labuan Coal Company (1865-6), and the Oriental Coal Company (1869-80). ${ }^{556}$ These concerns became bywords in the East for inefficiency, and there is no doubt that they were very wasteful and extravagant. Yet the chief difficulty they encountered was not of their own making. The problem of obtaining a suitable labour force always defied solution. Malays migrating from Brunei

656 Between 1882 and 1888 W. C. Cowie \& Co (later Cowie Bros) worked the Labuan and Muara coalfields with more success, and in 1888 sold the mainland rights to the Government of Sarawak. 
'signed on' at the Labuan coal mines for brief periods, but returned home again as soon as they had earned enough money to satisfy their immediate needs. ${ }^{557}$ Coolies imported from Singapore were equally unreliable. Some, whose constitutions were already weakened by overindulgence in opium, bhang, and arak, quickly died of fever. Others left the island immediately their indentures expired. ${ }^{558}$ Nor was the labour situation much improved when in 1857 the colony became a penal settlement for long-sentence convicts from Hong Kong. ${ }^{559}$ For humanitarian reasons the Colonial Office would not allow prisoners to be employed underground, except as volunteers, and this prohibition was maintained when convicts from Singapore began to be sent to Labuan after the transfer of the Straits Settlements from the East India Company to the Colonial Office in $1867 . .^{560}$ As a result, although convict labour was of great assistance in the construction of public works, ${ }^{561}$ and in the loading of coal into the bunkers of visiting ships, ${ }^{582}$ it did not help to solve the real problem, which was how to find even a small number of willing and efficient underground workers. Finally, the superior quality and comparative cheapness of English and Welsh coal on sale at Singapore forced the price of the Labuan product down so far that between 1850 and 1868 it had to be marketed at an average loss of $£ 1 \mathrm{a}$ ton in order to sell at all. ${ }^{\mathbf{5 6 3}}$

As a base for the suppression of Malay piracy, Labuan was equally ineffective. It was true that the depredations of the Lanuns and Balanini decreased markedly during the second half of the nineteenth century, but this was due on the one hand to general economic causes, and on the other to the exploits of Dutch, Spanish and British naval forces operating from Java, Manila, Singapore, Hong Kong, and Sarawak. The Government of Labuan did not possess so much as a single gun-

557 Lieutenant-Governor Scott to the Colonial Office, June 29th, 1853. (C.O. 144/11). Governor Edwardes to the Rt. Hon. Henry Labouchere, March 12th, 1857. (C.O. 144/14).

558 Labuan Coal Company to the Duke of Newcastle, December 12th, 1863. (C.O. 144/22). Labuan Coal Company to the Colonial Office, July 10th, 1864. (C.O. 144/23).

"The labour market at Labuan", stated a Colonial Office Minute of 1867, "is perhaps the worst in the world. It is supplied from the most dissolute classes of the population of Borneo". (C.O. 144/26).

559 Colonial Office to Sir John Bowring, June 1857. (Copy in C.O. 144/14).

580 Minute by Sir Frederick Rogers. (C.O. 144/26).

561 Minutes of the Legislative Council of Labuan, August 6th, 1870. (C.O. 434/1).

562 Governor Pope-Hennessy to Earl Granville, February 24th, 1869. (C.O. 144/29).

563 Pope-Hennessy to the Duke of Buckingham and Chandos, November 18th, 1868. (P.P., 1868-9, XLIII, pp. 297-9). 
boat of its own before 1877 . When British warships visited the northwest coast of Borneo, they usually based themselves on Kuching, not least, according to one disgruntled Governor of Labuan, because of "the very few attractions we have in this colony for naval officers". ${ }^{54}$ Indeed, so far from helping in the campaign against the pirates, Labuan indirectly hindered it, for its Government had made no attempt to restrict by law the sale of arms and ammunition, and many of the 'peaceful traders' who frequented its markets became pirates again as soon as their prahus cleared Victoria Harbour. ${ }^{565}$

Finally, as a commercial emporium, the colony completely failed to justify the British Government's hopes. Only a small fraction of the local prahu trade and very few European ships were attracted to it. The larger vessels avoided Labuan because the inadequacy of its wharves and warehouses caused expensive loading delays, ${ }^{568}$ while the smaller preferred to pick up their cargoes at Brunei and in the rivers along the coast. ${ }^{567}$ During the 1860 's only one white trader, Captain Ross, ${ }^{568}$ called regularly at Labuan, and the maintenance of steam communications between the British Empire and its lonely outpost on the Borneo coast thus depended entirely upon the goodwill of a private merchant. ${ }^{56 \theta}$

On several occasions members of the Colonial Office staff in London suggested that Labuan was an extravagance and that the settlement there ought to be withdrawn. "I firmly believe", wrote the Assistant Under-Secretary, T. F. Elliot, in 1858, "that, on its own merits, the place ought to be abandoned". ${ }^{570}$ But Lord Carnarvon, the Parliamentary Under-Secretary, thought it should be retained "not for ever, but

564 Pope-Hennesy to Earl Granville, April 11th, 1870. (C.O. 144/31).

In its earliest days Labuan had possessed some slight value to the Navy as a coal-depot, but by the 1880's the greatly increased endurance of steamships had made an auxiliary coal station between Hong Kong and Singapore unnecessary. (Admiralty to the Colonial Office, February 2nd, 1886: C.O. 144/62).

565 Governor Callaghan to the Rt. Hon. Edward Cardwell, January 26th, 1865. (C.O. 144/24). Minutes of the Legislative Council of Labuan, May 8th, 1866. (C.O. 434/1).

506 Governor Edwardes to Labouchere, December 8th, 1856. (P.P., 1857-8, XL, pp. 359-62).

587 The same to the same, April 29th, 1858. (P.P., 1859, Sess. ii, XXI, pp. 627-9).

508 The exploits of Captain Ross are described in the memoirs of his son, J. D. Ross, Sixty Years: Life and Adventure in the Far East (1911).

568 Governor Bulwer to the Farl of Kimberley, December 5th, 1872. (C.O. 144/38). Bulwer to the Earl of Carnarvon, July 4th, 1874. (C.O. 144/42).

570 Minute by T. F. Elliot, April 26th, 1858. (C.O. 144/15). 
for five or six years" in view of the growing importance of British trade with China. ${ }^{\mathbf{5 7 1}}$ Carnarvon's view prevailed, and 'Micawberism' regarding Labuan became almost an official Colonial Office policy. One coal company after another went bankrupt, but as each new Governor took charge of the island he persuaded his superiors in Downing Street that prosperity was just around the corner. This did not prevent the strictest economies being imposed, however, and by 1888 the European administrative staff had been reduced to two, an Acting-Governor and a gaoler. The gaoler lived two miles from the capital at Victoria, and in any case there were only seven convicts for him to look after. Being uneducated, he was of little assistance to the unfortunate Acting-Governor, an ex-naval officer named Hamilton, who had been retired from the service medically unfit. Hamilton was not only 'Acting-Governor and Commander-in-Chief of Labuan and its Dependencies and Acting Vice-Admiral of the same', but Colonial Secretary, Judge, Police Magistrate, Harbour-Master, Coroner, and Postmaster-General as well, and was forced to adopt many curious expedients to keep within the colonial regulations. On one occasion he had to make written application to himself as Colonial Treasurer for the funds he needed as Colonial Surveyor to build a new sanitary block at the civil hospital. ${ }^{572}$ This farcical situation came to an end on January 1 st, 1890 , when the island of Labuan, while still retaining the status of a British colony, was handed over for administrative purposes to the North Borneo Company. ${ }^{\mathbf{5 7 3}}$

It would be incorrect, however, to gauge the importance of Labuan solely in terms of its success or failure as a colony. From 1861 onwards the office of Governor of Labuan was merged with that of British Consul-General to the native states of Borneo, and it was upon the advice of their Consul-General that the Foreign Office necessarily had

571 Minute by the Earl of Carnarvon, April 26th, 1858. (Ibid.) A similar view had been expressed by Mr. Secretary Labouchere in 1856. (Colonial Office to the Treasury, November 26th, 1856: P.P., 1857, XXVI, pp. 518-19).

572 Acting-Governor Hamilton to the Colonial Office, April 2nd, 1888. (C.O. 144/65). Memorandum by A. S. Hamilton, September 19th, 1888. (Ibid.) Cf. W. H. Treacher, 'British Borneo: Sketches of Brunai, Sarawak, Labuan and North Borneo', JRASSB, 1890, pp. 46-7.

573 In 1871 Governor Pope-Hennessy had suggested that Labuan should be united with the Straits Settlements, but his proposal was rejected on the advice of Sir Harry Ord. ('Memorandum on the Union of Labuan to the Straits Settlements', P.P., 1872, XLIII, pp. 567-71. Sir H. Ord to the Earl of Kimberley, September 1st, 1873: C. O. 144/41). The Colonial Office resumed control again in 1906, when Labuan was transferred from the British North Borneo Company to the Government of the Straits Settlements. 
to rely when decisions were made affecting Brunei or Sarawak. Moreover, when the interests of these two states came into conflict, as often happened during the second half of the nineteenth century, the Sultan of Brunei automatically turned for support to the local representative at Labuan of his ally, the Queen of England, against his over-mighty vassal, the Raja of Sarawak.

The failure of the Singapore Commission of Inquiry of 1854 to clarify Sir James Brooke's position vis-à-vis the British Government meant that solutions had still to be found to two major problems, both primarily legal in nature, and both baffling in their complexity. They may be stated briefly as follows: first, Was Sarawak an independent state or technically a fief of the Sultanate of Brunei? and secondly, Were the responsibilities of its ruler - granting that he was in fact independent - compatible with the allegiance which he owed as a British subject to his own soverign? Brooke himself believed that he could answer both these questions satisfactorily, but the British Government proved extremely reluctant to accept either his reasoning or his conclusions.

The White Raja first laid claim to complete independence for his territory in a letter to the Foreign Office of March 10th, 1852. In this letter he asserted that his rights in Borneo were derived from a double title: he had not only been granted unrestricted sovereignty over Sarawak by the Sultan of Brunei in 1846, but he had also been raised to his present position as Raja by the free and unfettered choice of its inhabitants, who had themselves thrown off the Brunei yoke before his arrival in Borneo in $1839 .{ }^{.54} \mathrm{He}$ later reaffirmed these claims when giving evidence before the Commission of Inquiry ${ }^{575}$ and on many subsequent occasions.

In order to strengthen his case Brooke drew attention to two events which had occurred some years before the question of Sarawak's independence first arose. As long ago as March 1849, he pointed out, Lord Palmerston had given Foreign Öffice blessing to the use of a distinctive Sarawak flag - a cross of pale red and black on a yellow field ${ }^{576}$ This, in Brooke's opinion, was tantamount to recognition of the territory's independent status. Again, in May 1850 a treaty had been

574 F.O. $12 / 12$

575 P.P., 1854-5, XXIX, p. 222.

676 Brooke to Palmerston, March 14th, 1849. Palmerston to Brooke, June 20th, 1849. (P.P., 1851, LVI, Pt. i, pp. 141-2). 
concluded, on American initiative, between Sarawak and the United States. ${ }^{577}$ This showed that at least one of the great powers was willing to grant his claim to independence, and Brooke was at a loss to understand why Great Britain should not follow America's lead. ${ }^{578}$

A serious flaw in the White Raja's case was the existence of financial obligations as between Sarawak and the Sultan of Brunei. When in 1846 he had obtained a grant of the rivers from Cape Datu to the Samarahan, he had taken the opportunity of freeing himself from the burden of paying annual tribute. ${ }^{579}$ Since then, however, he had acquired a huge new tract of territory. In 1853 the northern boundary of Sarawak was extended to beyond the Rajang basin, and in exchange Brooke had agreed to pay the Sultan an annual sum of $\$ 1,500$. The original arrangement, moreover, by which Sarawak was obliged to pay $\$ 4,000$ to Brunei on the accession of a new Raja was still in force.

The question of Sarawak's independence was first put to the test in 1855, when Spenser St. John, a personal friend of the White Raja's, was appointed British Consul-General to the native states of Borneo. ${ }^{580}$ Brooke promptly informed the new Consul-General that he could not take up his duties until he had secured an exequatur from the Government of Sarawak. ${ }^{581}$ But when St. John asked the British Government for permission to do so, supporting his application with a vigorous defence of Sarawak's claim to independence, the Foreign Office refused to be drawn. ${ }^{582}$ "As a British subject", they told St. John, "Sir James Brooke cannot acquire independent sovereignty without permission from the Crown, ${ }^{583}$ such a position being inconsistent with the allegiance which he owes to his own Sovereign, and which, without the consent

577 J. Balestier (American Envoy and Minister to Southeast Asia) to G. Ruppell and A. Crookshank (Brooke's representatives at Kuching), May 27th, 1850. (F.O. 12/8).

A month later a similar treaty was concluded between the United States and Brunei. In both cases the object of the Americans was to secure reciprocal trading rights and protection for their shipping in the harbours of northern Borneo.

578 Brooke to the Earl of Clarendon, September 27th, 1853. (F.O. 12/13).

579 See p. 126, above.

580 This office had been resigned by Brooke in September 1853. His resignation, however, was not formally accepted until 1855 .

581 Brooke to St. John, October 25th, 1855. (F.O. 12/22).

582 St. John to Clarendon, November 3rd, 1855. (Ibid.)

583 In accordance with strict legal theory, the Crown automatically acquired sovereignty over any territory which came into the possession of a British subject. (See Sir Arthur Berriedale Keith, The Constitution, Administration, and Law's of the Empire, p. 289). 
of that Sovereign, he cannot put off". ${ }^{84}$ Since Brooke had not received the necessary royal permission, it followed that he could not be considered as an independent prince, and consequently that an exequatur from his Government need not be obtained by a British consul serving in Borneo.

His failure to secure recognition became the more serious for Brooke in 1857, when some of his Chinese subjects rose in revolt against his rule. Many Chinese communities in Southeast Asia had become greatly excited at the news of the British withdrawal from before Canton the previous year, and disturbances had broken out at Singapore and in other places. Representatives of the powerful secret society of the Thian Ti Hui ('Heaven and Earth League') came over from Malaya to Borneo in the hope of creating trouble there also. ${ }^{585}$ Partly because of their intrigues and partly because the Sarawak Government had recently punished a gold-mining kongsi at Bau (near the Sambas border) for opium-smuggling, a band of armed Chinese descended on Kuching in February 1857, destroyed most of the principal buildings, and murdered several of the European inhabitants. The White Raja himself barely escaped with his life. His Malay and Dyak subjects remained loyal to him, however, and with assistance from the Dutch at Pontianak and from the newly-founded Borneo Company, order was restored in Kuching and the shattered administration set on its feet again. ${ }^{\mathbf{5 8 6}}$ Nevertheless, the 'Chinese Insurrection of 1857', as it became known, went far to convince Brooke that Sarawak could not survive long without more effective European protection. At the height of the revolt he even went so far as to order the Borneo Company's local manager to "offer the country, on any terms, to the Dutch" - an act of surrender he would earlier have regarded as unthinkable.

Early in 1858, while on a visit to England to regain his health, he was asked by the Foreign Secretary, Lord Clarendon, to submit definite proposals regarding the future of his kingdom. In a memorandum dated February 4th of that year, he suggested that Sarawak should be trans-

684 Foreign Office to St. John, April 9th, 1856. (F.O. 12/23). This dispatch was based on advice given to the Foreign Office by the Law Officers of the Crown on February 15th of the same year. (F.O. 12/35).

586 Spenser St. John, Life in the Forests of the Far East, Vol. ii, p. 356. BaringGould and Bampfylde, op. cit., p. 189.

686 L. V. Helms, Pioneering in the Far East, pp. 193-4. Helms was the first manager of the Borneo Company, Limited, which was formed in 1856 to exploit the mineral and jungle products of Sarawak. Brooke received a loan of $\{5,000$ from this company to tide him over the immediate financial crisis caused by the Chinese Insurrection. 
ferred to the Crown in full sovereignty at once, but that he and his staff at Kuching should continue to administer it for the time being, since its revenues were not yet sufficiently large to support a full-scale colonial government. Sarawak was to become "a British possession with a native administration superintended by Englishmen". In compensation for the surrender of his sovereign rights, Brooke proposed that the money which he had laid out on the development of the area since 1839 should be refunded to him, and that a further sum, representing the value of the state revenues and other public property should be made available to him either immediately or when the Colonial Office assumed full control. ${ }^{587}$

The Prime Minister at this time was Lord Palmerston, who in the past had often supported the policy of expanding British influence in Borneo. If the decision had rested with Palmerston, Sarawak might well have become a British colony then and there. But on February 19th, only a fortnight after Brooke's proposals had been put forward, Palmerston's Government was defeated in the House of Commons, and he resigned the following day. The new Prime Minister was the Earl of Derby, and the Earl of Malmesbury succeeded Lord Clarendon at the Foreign Office. Brooke had therefore to begin his campaign for recognition all over again.

In August he submitted fresh proposals to Sir Edward BulwerLytton, the new Secretary of State for the Colonies. These were worded slightly differently from those he had made earlier, and showed that since February the White Raja had changed his ground. Although still willing for Sarawak to be made a Crown Colony, he stated that he now preferred that it should become a British protectorate. Under a protectorate, he believed, he would be free to order his country's internal affairs as he himself thought fit, whereas under the Colonial Office the religion, laws, and customs of the inhabitants might be interfered with. He therefore asked the British Government to extend formal protection to Sarawak, and at the same time to become its "public creditor" by taking over the state debt, amounting at this time to approximately $£ 50,000 .{ }^{588}$ In return, Great Britain was to have the right of establishing a Crown Colony at a later date should her interests require it. ${ }^{589}$

$587 \mathrm{~J}$. Brooke, 'Memorandum for the Earl of Clarendon', February 4th, 1858. (F.O. 12/25).

588 This figure represented the total sum which Brooke had invested in Sarawak since its foundation, plus $t 5,000$ which he owed to the Borneo Company.

589 The full text of this memorandum is given in Jacob, op. cit., Vol. ii, pp. 268-71. 
The immediate response of the British Government was not encouraging, and for the next five years Brooke fought hard to secure acceptance of these proposals, in whole or in part. His campaign to win recognition was conducted with a certain urgency, for the internal condition of Sarawak was far from satisfactory. The Chinese Insurrection had been followed in 1859 by the 'Musahor Revolt', in which two of his officers were treacherously murdered at Fort Kanowit on the Rajang. There was also a constant fear that the Bandjermasin War: then convulsing southern Borneo, would spread to the north-west coast. In many parts of the East, moreover, where, as in Sarawak, small white minorities were governing large, half-civilized native populations, the terrors of the Indian Mutiny were fresh in mind, and the prevailing atmosphere was one of fear and suspicion, in which rumours of impending revolution gained easy currency.

The British Government's persistent refusal to recognize his claims obliged Brooke to turn elsewhere for the support he needed. Early in 1859 he was considering the possibility of surrendering his kingdom to the Dutch. ${ }^{580} \mathrm{He}$ obtained a temporary respite from financial worries in April of that year, when a famous philanthropist, Miss Angela (later Baroness) Burdett-Coutts, paid the debt he owed to the Borneo Company, ${ }^{591}$ but early the following year he was again seeking foreign protection, this time from Emperor Napoleon III of France. A further grant of money from Miss Coutts enabled him to buy a steamer, and he assured her that "the services of such a vessel" would justify him

500 Many writers assert that Brooke in fact offered his country to the Netherlands and that his offer was rejected. (Cf. Colenbrander, op. cit., Deel i, p. 330. E. B. Kielstra, De Indische Archipel, p. 201, and Baring-Gould and Bampfylde, op. cit., p. 242).

I have been unable to find evidence in the records of the Dutch Foreign Ministry that such a proposal was ever made. Halfway through 1858 the London Times advocated the absorption of Sarawak by the Netherlands Indies and, as a result, the Dutch Ambassador in London received orders from The Hague "to bring to the notice of His Excellency Lord Malmesbury that the Government of the Netherlands have no idea whatever of taking advantage of the offer [which the Times suggests will soon be made] and by accepting which they would acquire a protectorate or sovereignty over the country of Sarawak." (Minister of Foreign Affairs to Baron Bentinck, September 21st, 1858, No. 1, Secret: Buit. Zaken, No. 3134).

Brooke undoubtedly had thoughts of transferring his country to Holland at this time. It may be that he approached the Dutch Ambassador privately on the subject and that the Ambassador's reply did not encourage him to make a more formal offer.

591 Brooke to Miss Burdett-Coutts, June 3rd, 1859. (Rajah Brooke \& Baroness Burdett Coutts (Ed. E. Owen Rutter), p. 62). 
in "maintaining Sarawak independently till circumstances... accommodate the differences with the British Government". 592 But late in 1860 he was negotiating with the Duke of Brabant for the transfer of his dominions to Belgium.

Not all Brooke's friends and advisers were in sympathy with these efforts to obtain protection from foreign governments. Indeed, his nephew and heir, Captain J. Brooke Brooke, whom he had left in charge of the Sarawak Government in 1858, was violently opposed to the idea of ceding the country to anyone, even to the British. Unlike the White Raja, Captain Brooke was satisfied that Sarawak could struggle through its present difficulties unaided, and, in a letter to the British Foreign Secretary, went so far as to protest formally against the proposed transfer ${ }^{503}$ His nephew's insubordination forced Sir James to hurry back to the Far East early in 1863 in order to regain control of his kingdom. By publicly opposing the Raja's policy, Captain Brooke brought into the open a quarrel which was essentially private in nature, ${ }^{584}$ and, in the interests of Sarawak, should have remained so. The House of Brooke may have been divided against itself, but it was unwise to proclaim this fact from the housetops. Captain Brooke's action helped to confirm the impression already formed by the Foreign Office that the White Raja's authority in Borneo was ephemeral, and that no useful purpose would be served by becoming directly involved in the fortunes of his kingdom.

In deciding on the best policy to be adopted towards Sarawak, the British Government had a choice of four possible courses of action. First, they could waive all legal technicalities, recognize the White Raja as an independent sovereign, but refrain from any positive intervention in the affairs of Borneo. The difficulty here was that, like any other

582 Brooke to Miss Burdett-Coutts, June 6th, 1860. (Ibid., p. 78).

The White Raja also received a testimonial of $£ 8,800$ at about this time, subscribed by a group of his admirers in England.

Captain Brooke Brooke to Lord Russell, October 26th, 1862. (F.O. 12/30).

504 The real reason for the falling-out of uncle and nephew was James Brooke's recognition of the existence of his illegitimate son, George, whom Brooke Brooke feared might supplant him as the heir-apparent of Sarawak. Following the code of the Victorian Age, the White Raja's early biographers avoided all reference to this by-blow of their hero's younger days, and speculations regarding the mysterious 'Reuben George Brooke' were consequently a favourite topic of conversation in pre-War Borneo. In her recent book, James Brooke of Sarazvak (London, 1953), however, Miss Emily Hahn has given a full account of this matter (pp. 223-30), and satisfactorily clears up many other problems connected with the secret history of the First White Raja of Sarawak. 
British subject residing in a savage land, Brooke already had a right to the protection of his mother country from foreign states or individuals who threatened to take his life or steal his property. In practice, therefore, for the Foreign Office to recognize him as Raja would be equivalent to granting him a protectorate. By claiming to be the head of an independent state without renouncing his nationality, Brooke was really trying to have the best of two worlds. His constant applications for British naval support were strictly incompatible with his insistence on being regarded as a sovereign prince. ${ }^{595}$

Next, the British Government could accept the offer of Sarawak, pay the compensation Brooke demanded, and convert his kingdom into a Crown Colony. But all the evidence seemed to show that such a colony would be an even greater drain on the Imperial Exchequer than Labuan which, small though it might be, was costing some $£ 6,000$ a year at

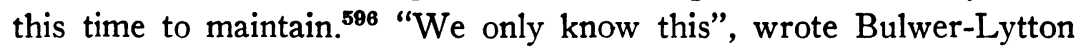
in 1859, "that the present Proprietor, keeping the most modest Establishment he can, is unable to make both ends meet, and is in debt... The probability is, therefore, that the Colony would not be self-supporting". ${ }^{587}$ The British Government, moreover, had yet to be convinced that Brooke possessed actual sovereign rights to dispose of. His assertion that he held his country both by the will of the people and by covenant with Brunei was regarded by the Foreign Office as absurd, while the existence of such clearly defined financial obligations to the Sultan made his claim to complete independence logically untenable. ${ }^{588}$

Thirdly, and this was the course favoured by most of Brooke's supporters in England, the Foreign Office could guarantee the stability of Sarawak by formally declaring a protectorate over it. But here again the probable disadvantages seemed likely to outweigh the possible benefits. When a deputation of Glasgow, Manchester, Liverpool, and London merchants waited on the Prime Minister, Lord Derby, in November 1858 to urge him to grant a protectorate, he told them that there was "a very strong argument... against sanctioning such undertakings as those of Sir James Brooke... If every English subject were

506 Foreign Office Minute of June 3rd, 1861. (F.O. 12/29).

508 During the period 1857-64 the following Parliamentary grants in aid were voted on behalf of Labuan:

$\begin{array}{rrrr}1857 & £ 3,894 & 1861 & \pm 6,743 \\ 1858 & 6,790 & 1862 & 5,200 \\ 1859 & 5,438 & 1863 & 7,037 \\ 1860 & 6,893 & 1864 & 5,736\end{array}$

687 Minute by Sir E. Bulwer-Lytton, 1859 (n.d.). (F.O. 12/35).

${ }^{898}$ Memorandum by C. Spring Rice, January 7th, 1859. (Ibid.) 
to be allowed to settle in any district he might think fit, and afterwards to call upon the Government as a matter of right to give him military and civil protection, and to secure him from the consequences of conduct which was not in the slightest degree anticipated by the Government, it must lead the Government into endless difficulties and expenditure". ${ }^{589}$ This dictum was later endorsed by the Earl of Clarendon, who declared in 1869 that he "did not fancy protecting a British rajah who might want our support but defy our authority". ${ }^{800}$

The fourth course open to the British Government was the one they eventually adopted, namely, to reject Brooke's claims and proposals entirely. The friends of Sarawak were greatly disgusted at what they regarded not only as a betrayal of a man who deserved better of his country, but as a foolish, if not criminal, blindness to the value of British interests in Borneo. Yet Brooke's plans were defeated not so much by official ignorance and apathy as by the belief then prevailing in England that there were too many British colonies already. In view of the aggressiveness of British policy in Borneo in the 1840's, it seems safe to say that if, in 1858, Her Majesty's Government had really wanted Sarawak, they would not have allowed $£ 50,000$ and a few unsolved legal conundrums to stand in their way.

Although a protectorate for Sarawak was thus definitely denied him, Brooke had the satisfaction of winning one minor battle with the Foreign Office - the argument about British consular representation at his capital. In August 1863, through the personal intervention of Lord Palmerston, ${ }^{601}$ Cabinet approval was given for the appointment of a British consul specifically to Kuching, and instructions were issued by the Foreign Secretary that this official was to obtain his exequatur from "Sir James Brooke, Raja of Sarawak". ${ }^{602}$ Historians of Sarawak have always claimed that this order marked the "full and complete" recognition of the country's independence, ${ }^{803}$ and Palmerston, at any rate, certainly intended it to convey that implication. ${ }^{604}$ But, whether by accident or design, the commission furnished to Mr. Ricketts, the

599 The Times, December 1st, 1858.

600 Minute by the Earl of Clarendon. (F.O. 12/40).

601 Palmerston was persuaded to exert his influence in this matter by Mr. John Abel Smith, M.P., who was in turn acting on behalf of Miss Burdett-Coutts. (See Rajah Brooke \& Baroness Burdett Coutts, p. 213).

602 Memorandum by Earl Russell, August 1863. (F.O. 12/42).

003 Cf. Baring-Gould and Bampfylde, op. cit., pp. 280-1.

604 In a letter of May 22nd to Lord Russell, Abel Smith wrote: "I am happy to add that [Lord Palmerston] has authorized me to tell you that he has no 
first British consul to Kuching, was drawn up in such a manner as to leave the British Foreign Office a loop-hole through which they could escape whenever the demands of the Sarawak Government for 'full and complete' recognition were strongly pressed. As framed by the Foreign Office staff, Ricketts' commission made no mention of the 'dominions' of the sovereign to whose territory he was being appointed, and he was instructed to obtain his exequatur, not from the Raja of Sarawak, but from "the local authorities". ${ }^{805}$ Whether these "local authorities' were European or native was not laid down. In consequence, as late as 1877 the Foreign Office were able to claim that "as a matter of constitutional law it is competent to the Queen to recognize [the Raja of Sarawak] as a sovereign prince, but no such recognition has taken place". ${ }^{.08}$

When at the end of 1863 Sir James Brooke sailed from Borneo for the last time on his way to permanent retirement in England, he left behind him a country with a well-organized internal administration, but without that guarantee of protection from a European power which for more than twenty years he had vainly tried to secure. In 1866 he made one final attempt to persuade the British Government to accept sovereignty over his kingdom, ${ }^{807}$ but once again his offer was rejected. "It seemed of neither sufficient political nor commercial importance", wrote the Colonial Under-Secretary of the day, C. B. Adderley, "to tempt us 450 miles inland [sic] from Labuan, and we had found Asiatic Stations already too burdensome financially. Sarawak imports coal from Labuan, and is worth more to the Crown as a foreign

objection to the immediate recognition of Sarawak, and he repeated that it will be a pleasure to him to find himself in a position to do anything agreeable to Sir James Brooke."

605 Memorandum by Sir Edward Hertslet, December 29th, 1876. (F.O. 12/42).

${ }^{606}$ Foreign Office Minute of 1877 (n.d.). (Quoted in C.O. 144/49: my italics). In 1869 Charles Brooke, the Second White Raja, asked for an invitation to a royal levee, but refused to attend when he was told that he would have to be presented as 'Mr. Brooke', or not at all. (Foreign Office Minute of May 24th, 1869: F.O. 12/34B). Five years later, when he again sought permission to attend a levee in his sovereign capacity, the matter was referred to Queen Victoria, who was "graciously pleased to consent to the suggestion that he should write on his card and be presented as 'Mr. Brooke (Rajah of Sarawak)'." He was told privately, however, that in all other respects he would rank as a private individual. (Memorandum by Sir Edward Hertslet, December 29th, 1876: F.O. 12/42).

During the reign of Edward VII approval was eventually given for the Rajas of Sarawak to take precedence at Court immediately after the ruling princes of India. (Ranee Margaret of Sarawak, My Life in Sarazwak, p. 311).

607 Brooke to Lord Stanley, November 3rd, 1866. (F.O. 12/35). 
customer than it would ever become as a subject". ${ }^{008}$ Two years later, on June 11th, 1868, James Brooke died at his home in Devonshire, and the Raj passed to his nephew, Charles Johnson Brooke, the Tuan Muda. ${ }^{609}$

008 C. B. Adderley, Review of "The Colonial Policy of Lord J. Russell's Administration", by Earl Grey, 1853; and of Subsequent Colonial History, p. 343. 009 'The Last Will and Testament of Sir James Brooke, K.C.B., First Rajah of Sarawak', April 15th, 1867. This document was not published in full until seventy-eight years after James Brooke's death, because it made incidental reference to his illegitimate son, George. It may be found in a pamphlet entitled, The Facts about Sarawak (London, 1946). 


\section{CHAPTER $\mathrm{X}$}

\section{THE PARTITION OF BORNEO}

The dominions inherited by the Second White Raja of Sarawak extended from Cape Datu on the Sambas border to Cape Kidurong, a small promontory seven miles north of the mouth of the Bintulu River. The greater part of this territory had been acquired in two huge 'bites': the first in 1853, when the Rajang Basin was absorbed, and the second in 1861, when the frontier was moved up the coast to beyond the Bintulu. The motives which prompted the Sarawak Government to demand this second cession were primarily economic. The country between the Rajang and the Bintulu included the districts of Oya and Mukah, which together supplied most of the sago then being exported from Kuching to Singapore. Native traders from Sarawak visiting the sago districts had often been maltreated by the local Brunei chiefs, and taxes and tolls levied on their goods. ${ }^{610}$ The Sarawak Government had therefore considered it imperative to remove these obstructions to a trade that was vital to the country's prosperity, and the cession of 1861 had been negotiated, the Sultan of Brunei receiving a compensation for the loss of this territory amounting to $\$ 4,500$ annually. ${ }^{611}$

This policy of expansion northwards, begun during the reign of the First Raja, was continued by his successor. Early in 1868 Charles Brooke asked the Sultan of Brunei if he would cede the district of Baram in return for a suitable yearly payment; ${ }^{612}$ by acquiring this area Brooke was planning to add another hundred miles to Sarawak's coastline. The Sultan refused to consider any such proposal, however, and appealed for support against the 'aggression' of Sarawak to Governor Pope-Hennessy of Labuan (who was also British ConsulGeneral for Borneo), claiming that Brunei had a right to British

610 Singapore Chamber of Commerce to Lord Russell, October 5th, 1860. (F.O. 12/28).

611 Spenser St. John to Lord Russell, August 29th, 1861. (F.O. 12/29).

12 This was some months before Charles Brooke actually acceded to the Raj, but he was already administering the Government with full powers in his uncle's name. 
protection under the Treaty of $1847 . .^{613}$ Pope-Hennessy announced that he would be willing to act as arbitrator in the matter, if both parties wished him to do so ${ }^{614}$ - a suggestion which greatly irritated Brooke, who believed that sovereign powers like Sarawak and Brunei had no need of outside assistance in the management of their affairs. The Governor of Labuan, he complained to the British Foreign Office, had been listening to "false and cunning statements" from the Sultan of Brunei, upon whose word no credence could be placed. A simple matter like the cession of Baram could be settled by the Brunei and Sarawak Governments alone, and he was "ignorant why it should require interference from other parties". ${ }^{615}$ The Foreign Office, however, were not so easily to be persuaded to lay aside the responsibilities they believed Great Britain owed to Brunei. "You will ... remind the Raja of Sarawak", they told Pope-Hennessy at the end of 1868, "of the provisions in our Treaty with Brunei against the cession of territory without the consent of the British Government, and, in so doing, you will state that $\mathrm{H}$. M. Government have no desire to see any change in the present state of territorial possession in Borneo, nor are they disposed to countenance any attempt to induce the Sultan to act in contravention to that Treaty".616

The British Government maintained their opposition to territorial changes in Borneo for the next ten years. In 1874 Brooke suggested that Great Britain should declare a protectorate over the whole of Brunei or, alternatively, should allow the Government of Sarawak to do so. Neither proposal was acceptable to the Foreign Office. Her Majesty's Government, he was told, had no thought of extending protection to Brunei themselves, nor did they favour "any considerable extension" of his own "anomalous jurisdiction". ${ }^{617}$ Two years later he asked the Foreign Office to waive the stipulation in the 1847 Treaty which forbade the Sultan to alienate territory without British consent, and once again his request was bluntly refused. ${ }^{618}$

Brooke was understandably annoyed at not being allowed to enlarge his dominions at the expense of Brunei, which he regarded as "debased,

613 Sultan of Brunei to Governor Pope-Hennessy, April 13th, 1868. (F.O. 12/34A). 614 Governor Pope-Hennessy to Charles Brooke, April 23rd, 1868. (C.O. 144/28).

615 Charles Brooke to Lord Stanley, April 30th, 1868. (Ibid.)

${ }_{616}$ Foreign Office to Governor Pope-Hennessy, December 2nd, 1868. (F.O. 12/34A).

617 Earl of Derby to Charles Brooke, May 10th, 1875. (F.O. 12/42).

618 Charles Brooke to the Foreign Office, March 20th, 1876. Foreign Office to Sir James Brooke (sicl), June 12th, 1876. (C.O. 144/47). 
sordid, exacting, and unreliable". ${ }^{19}$ The inhabitants of a district like Baram, he contended, would be much happier under his rule than under their rapacious Brunei overlords. He laid the blame for the British Government's restrictive policy on the Governors of Labuan, who, he believed, were unfairly prejudiced against Sarawak, and had been using their influence with the Foreign Office to sabotage his plans.

Most Governors of Labuan between 1860 and 1880 were in fact jealous of Sarawak, and with good reason, for they saw in its expansion along the north-west coast a threat to the prosperity, if not the existence, of their own colony. The reports they sent home of the "restless aspirations of the Sarawak Government for territorial aggrandizement" ${ }^{20}$ consequently tended to emphasize the less reputable incidents in the story of Sarawak-Brunei relations. When, for example, Governor PopeHennessy advised the Foreign Office in April 1868 that Brooke was trying to obtain the district of Baram, he disclosed that during the previous year the Sarawak Government had 'fined' the Sultan $\$ 4,000$ for "breach of dignity". Letters had arrived from Brunei with the seal fixed much higher up the paper than was customary, and the General Council at Kuching had decided that this was a calculated insult. Only one third of the annual tribute money owing to the Sultan had therefore been paid. ${ }^{621}$ In 1876 Brooke again held back a large sum $(\$ 3,805)$ from the tribute money, because some debts due to Sarawak traders from a Brunei nakodah were outstanding. "I learn", wrote Governor Ussher to Lord Derby, the British Foreign Secretary, "that Raja Brooke offered to forego his deduction of the debts and other matters, if the Sultan would cede him Baram. I fear this aspect considerably diminishes the integrity of the transaction". ${ }^{022}$

These reports from Labuan were responsible for the British Government's conviction that Brunei required protection from the encroachments of Sarawak, and led to the Foreign Office ban on territorial changes in northern Borneo. It was obvious that Great Britain had the power to impose such a ban. That she had a moral duty to support a weak native ruler, with whom she was allied by treaty, against a powerful and ambitious neighbour was arguable. But whether she had any legal right to interfere in a dispute involving the transfer of territory from Brunei to Sarawak was extremely doubtful.

\footnotetext{
619 Charles Brooke to Governor Pope-Hennessy, April 30th, 1868. (C.O. 144/28).

620 Governor Bulwer to Earl Granville, June 18th, 1872. (C.O. 144/37).

621 Minutes of the Sarawak General Council, September 8th, 1867. Governor Pope-Hennessy to the Foreign Office, April 23rd, 1868. (C.O. 144/28).

622 Governor Ussher to Lord Derby, September 15th, 1876. (C.O. 144/46).
} 
By the Treaty of 1847 the Sultan of Brunei had promised not to cede "any part of his dominions to any other nation, or to the subjects or citizens thereof, without the consent of Her Britannic Majesty". ${ }^{623}$ But there was nothing in this Treaty to prevent him from ceding territory to the subjects of Great Britain. Indeed, since 1847 he had twice made over large sections of his dominions to a British subject (Sir James Brooke) and on neither occasion had he secured Foreign Office approval beforehand. When these cessions had later been reported to the British Government, moreover, no objection to them had been raised. But now, when Sir James Brooke's successor, also a British subject, wished to negotiate a precisely similar cession, the Foreign Office assumed the right to check him.

There was a strange inconsistency at this time in the attitude of the British Government towards Sarawak. From the beginning, as has been shown, the Foreign Office firmly refused to recognize the territory of the White Rajas as an independent state, yet the logical consequence of this refusal do not appear to have been understood. If the Brookes were not independent sovereign princes, then they were obviously vassals of Brunei, and, in that case, the grants made by the Sultan to the First Raja were feudal in nature, and not to be regarded as absolute cessions of territory. From this it should have followed that further grants of the same kind would not be contrary to the Treaty of 1847 , the purpose of which had been to prevent the Sultan of Brunei from alienating his country permanently to foreign nations, not from farming portions of it to British subjects in exchange for an annual tribute. In denying to Charles Brooke the right to acquire land in Brunei, the Foreign Office were recognizing the fact of Sarawak's independence and, at the same time, refusing to admit that it was independent in theory.

Such a policy, whether logical or not, was feasible only so long as no other powers besides Sarawak had territorial designs on the Sultanate of Brunei. But during the 1860's and 1870's several foreign Governments, including some who had never previously shown any interest in Borneo, began to realize that the northern part of the island possessed considerable commercial and strategic possibilities. The growth of foreign competition obliged the British Government to reexamine their policy towards Sarawak, since if Brooke were not allowed

623 Treaty of May 27th, 1847, Article X. (F.O. 93/16 (2). Maxwell and Gibson, op. cit., p. 146). 
to absorb the Sultanate of Brunei there was a risk that it might before long be swallowed up by an alien power.

Early in July $1865 \mathrm{Mr}$. Charles Lee Moses, who had recently been appointed United States Consul to Brunei, arrived at the Sultan's capital to take up his duties. These presumably consisted in giving advice to visiting American merchant ships, but Moses was not a man to neglect the opportunities for private gain to which his official position provided access. By emphasizing that he was an accredited representative of the Government of the United States, he succeeded in persuading the Sultan and Pěngeran Tĕmĕnggong of Brunei to grant him a personal ten-year lease of the greater part of northern Borneo, together with the islands of Banggi, Balabac, and Palawan, in exchange for an annual rental of $\$ 9,500$. 204

Having negotiated this remarkable bargain, Moses departed for Hong Kong, where he transferred his rights to the 'American Trading Company of Borneo'. The president of this company was a certain Joseph Torrey, who travelled to Brunei the following November in order to be installed as 'Raja of Ambong and Marudu and Supreme Ruler of the whole of the northern portion of Borneo'. ${ }^{225}$ Under Torrey's guidance a small plantation and trading settlement, staffed by 10 Americans and 60 Chinese coolies, was established on the shores of Kimanis Bay. The enterprise was financed temporarily by loans from the Chinese merchant community at Labuan. ${ }^{228}$

Torrey soon quarrelled with Moses, however, and went back to Hong Kong, hotly pursued by one of his Labuan creditors. The settlement at Kimanis languished, became bankrupt, and at the end of 1866 finally died. ${ }^{627}$ From then on the American Company ${ }^{628}$ confined itself to occasional trading ventures on the Borneo coast. Torrey and his associates still retained their title to most of northern Borneo, however,

624 Governor Callaghan to the Foreign Office, July 8th, 1865. (F.O. 12/32B).

625 Proclamation by Joseph William Torrey, December 21st, 1865. (F.O. 12/33A).

028 Governor Bulwer to Earl Granville, August 17th, 1872. (C.O. 144/37).

627 Acting-Governor Low to Lord Stanley, December 1st, 1866. (C.O. 144/25).

628 In 1868 Torrey was in New York, trying to obtain new financial backing. A prospectus for a new 'American Trading Company of Borneo' published by him that year spoke of the country's "enormous wealth, the salubrity of its climate, and the unsurpassed fertility of its soil." "The auriferous deposits", Torrey announced, were "only equalled by the Australian and California mines." The latter was a large claim, since gold had not then been discovered in northern Borneo, at any rate by Europeans. (American Trading Company of Borneo: organized under special concession from His Highness the Sultan 
though it remained to be seen whether they would be able to profit by it.

The next 'interlopers' to appear on the north-west coast of Borneo were the Italians. In February 1870 Captain Racchia of the Royal Italian Navy brought his ship, the Principessa Clotilde, to anchor in Labuan harbour, and astonished the British authorities there by announcing that he had been instructed to look for a site in Borneo for a penal colony. ${ }^{629}$ For some time past the Government of Italy had been trying to create such a colony, but their attempts to do so in Abyssinia, Socotra, and the Nicobars had all been frustrated. ${ }^{630}$ Racchia examined the coast opposite Labuan, and decided to recommend Gaya Bay, generally recognized as the finest anchorage in north-western Borneo. The British at Labuan complained to the Colonial Office that an Italian penal colony would corrupt the people of Brunei, ${ }^{631}$ and a long correspondence ensued between London and Rome on the subject. In the end nothing came of the plan, since in 1873 the Italian Government abandoned of their own accord all idea of transporting convicts overseas. ${ }^{\text {832 }}$

Meanwhile the Spanish Government of the Philippines had become involved in what proved to be the final phase in their seemingly endless contest with the Sultans of Sulu. Spain had first occupied Sulu in 1638 , but since then, despite frequent military expeditions and numerous treaties of friendship and mutual protection, its piratical and warlike inhabitants had never submitted to the Spanish yoke for more than a few years at a time. ${ }^{633}$ In 1851 , for example, after his capital had been occupied by Spanish troops, the Sultan agreed to make a "solemn act of incorporation and adhesion to the sovereignty of Her Catholic Majesty", and promised to suppress piracy in his dominions, but four years later raiders from Sulu captured and burnt the greater part of Zamboanga. ${ }^{634}$ Spanish intentions with regard to this area were of importance to the future of Borneo because the Sultans of Sulu possessed hereditary sovereign rights over the whole of the north-east coast

of Borneo ..., New York, 1868). The business men of New York, however, were not to be persuaded to invest in wild-cat schemes of Torrey's devising, nor were the American Government ready to listen to his plea that the U.S. Navy needed a base on the island of Banggi.

${ }^{629}$ Governor Pope-Hennessy to Earl Granville, April 11th, 1870. (C.O. 144/31).

630 Chevalier Cadorna (Italian Ambassador in London) to Earl Granville, January 29th, 1872. (C.O. 144/39).

631 Governor Bulwer to Lord Kimberley, January 15th, 1873. (C.O. 144/40).

632 C.O. $144 / 40$ and 41.

033 Najeeb M. Saleeby, The History of Sulu, pp. 177-200.

634 Ibid., pp. 209 and 214. 
from Boeloengan to Marudu Bay and over the north-west coast as far south as Pandasan. ${ }^{\text {ess }}$

In 1873 the Government of the Philippines decided to subdue Sulu once and for all. This could best be done, they believed, by driving away all trading prahus and by blockading all ports. "Every vessel coming from the Sulu Archipelago and manned by Moors [ie. Moros]", ordered the naval commander-in-chief at Manila, "shall be destroyed, and its crew and passengers destined to labour on public works... If the vessels ... be armed, they shall, as our laws direct, be held as pirates, and their crews be tried by court-martial ... Every vessel, although it may not be manned, belonging to the Moors of the Islands of Sulu and Tawi Tawi, shall be destroyed by the cruisers". ${ }^{636}$ In addition, foreign nations were peremptorily informed that no ships other than those sailing under Spanish colours would be permitted to trade directly with Sulu or with any of its dependencies. ${ }^{637}$

Most of the overseas trade of Sulu was in the hands of British and German firms at Singapore, who became highly indignant when a Spanish blockade was declared. Prompted by Sir Harry Ord, Governor of the Straits Settlements, the British Government lodged a protest in Madrid against the restrictions, while the German Government, which had already sent a warship to Sulu to conduct an investigation on the spot, suggested that Germany and England, by joint action, should compel Spain to restore freedom of trade to the Archipelago. Neither the British nor the German Government, it was pointed out, had ever admitted that Sulu formed part of the Spanish Philippines. ${ }^{\text {as8 }}$

Bringing pressure to bear on Spain by the methods of diplomacy, however, was a tedious process, and while negotiations dragged on in Europe, several enterprising merchant skippers in the Far East started a brisk smuggling trade with the proscribed Sulu ports. The small Spanish naval forces based on the Philippines were able to intercept only a small portion of this traffic, but they did succeed in capturing a few blockade-runners, and Anglo-German protests became

635 Sir Hugh Low, 'Selesîlah...', JRASSB, June 1880, pp. 13-17.

638 Orders issued by Rear-Admiral Don Juan Antequera y Bobadilla, August 2nd, 1873. (P.P., 1882, LXXXI, p. 338).

687 Notification by the Spanish Consul in Singapore, published in the Straits Settlements Government Gazette of November 7th, 1873.

63 Governor Ord to Lord Kimberley, March 13th, 1873. Earl Granville to Mr. Layard (British Ambassador in Madrid), October 20th, 1873. Count Münster (German Ambassador in London) to Earl Granville, January 19th, 1874. Governor Bulwer to Earl Granville, March 22nd and April 10th, 1873. (C.O. 144/40). 
stronger than ever. At last, in November 1876, the Government of the Philippines agreed to open Jolo, the main port of Sulu, to the trade of all nations, and the following year a protocol was signed in Madrid by England, Germany, and Spain, providing for "free access" and "free trade and navigation" throughout the whole Sulu Archipelago. ${ }^{.38}$

Although Spain was thus compelled to rescind her blockade policy, she had no intention of abandoning the struggle altogether. Indeed, she was now all the more determined to conquer Sulu. In 1876 Spanish troops had made a successful assault on Jolo, and garrisons had been installed at strategic points in the Archipelago. Unrest continued during the following two years, but all outbreaks were harshly suppressed, and by the middle of 1878 the people of Sulu were ready to admit defeat. On July 20th of that year "articles of pacification and capitulation" were signed at the Sultan's capital, and Spanish sovereignty proclaimed over all his dominions, including those on the mainland of Borneo. ${ }^{640}$ Already, however, events in that island had placed His Highness' mainland possessions beyond the Spanish sphere of influence for ever.

One of the most successful of the merchant ship captains who ran the Sulu blockade during the 1870's was W. C. Cowie, a Scot employed by Carl Schomburgk and Company, of Singapore. Cowie received many favours from the Sultan of Sulu, including permission to erect a transshipment depot for his merchandise at Sandakan, a fine natural harbour on the north-east cost of Borneo. He later entered into partnership with Schomburgk and with Captain Ross, another trader with wide experience of the Eastern Seas, and the three men formed the 'Labuan Trading Company', the sole purpose of which, despite its apparently innocent title, was to smuggle guns, ammunition, opium, tobacco, and other contraband into Sulu. ${ }^{\text {841 }}$

In order to dispose of the barter goods which he collected in northern Borneo and the nearby islands, Cowie made a practice of paying occasional visits to Hong Kong. During one of these trips, while arranging for the sale of a cargo of pearls and rattans, he received an

689 Decree of the Government of the Philippines of November 16th, 1876, and Protocol of March 11th, 1877. (P.P., 1882, LXXXI, pp. 434 and 545-7).

640 Saleeby, op. cit., pp. 222-31.

641 W. C. Cowie, 'North Borneo and how it became British', London and China Express, November 27th, 1908 (Supplement). 'Confidential report on the state of the Sulu Archipelago', by Commander Buckle, R.N., June 3rd, 1873. (C.O. 144/45). See also F. W. Burbidge, The Gardens of the Sun, pp. 183-4. 
unexpected demand for a ten per cent 'export duty' from Joseph Torrey, the only surviving member of the American Trading Company, and now the manager of a Hong Kong sugar refinery. Cowie had not previously been aware of the existence of Torrey's Bornean concessions, but he immediately saw their value, and suggested to his two partners that they should join with him in buying the American out. Ross and Schomburgk, however, would not agree. ${ }^{642}$

Although Cowie did not know it, the Bornean concessions had already attracted the attention of a resident of Hong Kong who was in a position to make better use of them than an impecunious Scottish gunrunner. ${ }^{043}$ This was Baron von Overbeck, consul at Hong Kong of the Austro-Hungarian Empire, and at one time the local manager of the great China opium firm of Dent and Company. In 1874 Overbeck visited London, and submitted a scheme for acquiring Torrey's rights to the Austrian Ambassador, Count Montgelas, who, in turn, fired the enthusiasm of certain capitalists in Vienna. As a result an Austrian warship was sent to Labuan in May 1875 to inquire into commercial prospects. Yet another European power had become involved in the fortunes of northern Borneo. ${ }^{\text {E4s }}$

Returning from Europe to Hong Kong in January 1875, Overbeck purchased Torrey's rights in the American Trading Company, ${ }^{845}$ and the following June visited Brunei himself to make sure that the concessions he had just bought were valid. (The leases acquired by Moses in 1865 , it will be recalled, were to run for a period of ten years only). Having satisfied himself on this score, the Baron entered into partnership with Alfred Dent, a son of his former employer, who undertook to supply most of the necessary financial backing. Two years later Overbeck made a second journey to Brunei in order to negotiate a permanent settlement with the Sultan..$^{648}$

642 Cowie, op. cit.

643 Cowie later became Managing Director and Chairman of the British North Borneo Company and spread abroad the story that he was that Company's real founder. The facts do not support him. (See K. G. Tregonning, 'The administration and development of North Borneo by the British North Borneo Company, 1881-1903', Unpublished Dissertation, University of Oxford, 1952, p. 21).

644 Acting-Governor Low to the Foreign Office, May 30th, 1875. (F.O. 12/41). Governor Treacher to Lord Derby, January 2nd, 1878. (C.O. 144/50).

046 Tregonning, op. cit., p. 20.

-48 Acting-Governor Low to Lord Carnarvon, July 6th, 1875. (C.O. 144/44). 'Memorandum respecting the cessions to Messrs. Dent and Overbeck...' (Printed for the use of the Cabinet, October 6th, 1879: F.O. 12/54).

The total capital of the North Borneo enterprise at this stage was $£ 10,000$, 
On December 29th, 1877, by means of four separate instruments, the Sultan and Pĕngeran Tĕmĕnggong of Brunei ceded to Baron von Overbeck and Alfred Dent, Esq., all the territories, rivers, lands, and provinces lying in the area between Kimanis Bay on the north-west coast of Borneo and Seboekoe River on the east. ${ }^{647}$ Baron von Overbeck was created 'Maharaja of Sabah and Raja of Gaya and Sandakan', ${ }^{648}$ with powers of life and death over the native populations in the ceded areas, absolute ownership of all agricultural, animal, and mineral products of the country, the right to make laws, coin money, create an army and navy, and levy customs duties and taxes, with "all other powers and rights usually exercised by and belonging to sovereign rulers". ${ }^{649}$ In exchange the Sultan was to receive $\$ 12,000$ annually, and the Tĕmĕnggong $\$ 3,000$.

The Pĕngeran Tĕmĕnggong was involved in these transactions because of the complicated system of land tenure then operating in Brunei. All revenues, whether from land or taxation, fell into three categories: kĕrajaan (lit. 'rule, empire'), implying, in this case, state revenues which were automatically inherited by a new Sultan from his predecessor; koripan, a name given to revenues allotted to a state official by virtue of his office; and tulin or pěsaka (lit. 'heirloom') revenues belonging to anyone, whether Sultan, noble, headman, or commoner, in his private capacity. The Tĕmĕnggong of Brunei possessed tulin rights over some of the districts bordering on Kimanis Bay, and was consequently able to participate in the tribute money offered by (or extracted from) Baron von Overbeck. ${ }^{\text {aso }}$

It will immediately be seen that the recipients of these grants acquired far wider powers than the Dutch had ever obtained from the princes in their part of Borneo. Under the Dutch system, as applied on the West and East Coasts, though not on the South, a sultan or raja who had ceded his territories to the Netherlands Government continued to administer them as a sovereign prince (by and with the advice of a

of which Dent had contributed $£ 6,000$. Torrey surrendered his rights to Overbeck for $£ 15,000$, less the costs of the expedition of 1877-8. (Governor Treacher to Lord Derby, January 2nd, 1878: C.O. 144/50).

647 Maxwell and Gibson, op. cit., pp. 154-6. These cessions did not confer a title to the entire coastline between the points named, but they were sufficiently comprehensive for Overbeck's purpose.

648 'Sabah' was originally a native name for certain parts of the north-west coast, but later became applicable to the State of North Borneo as a whole.

649 Maxwell and Gibson, op. cit., p. 157.

650 This paragraph is based on a memorandum written by Administrator Leys of Labuan, dated December 14th, 1885. (C.O. 144/59). 
Dutch official), and his jurisdiction extended to all persons in his dominions except Europeans, Chinese and other 'foreign orientals', and those of his subjects who were employed in Government establishments. $^{651}$ The powers conferred on Overbeck, on the other hand, constituted an absolute transfer of sovereignty. He was given the right to set up an independent state, not within the Sultan of Brunei's dominions, but entirely separate from them. The grants were subject to one proviso only, namely, that if the tribute money were not paid for three consecutive years the leases would lapse. But it cannot be supposed that the Sultan of Brunei, weak and impoverished as he was, would ever have been able to regain possession of his territories, once having surrendered them.

Indeed, as Overbeck well knew, the Sultan of Brunei did not exercise any effective rule in most of the territory he now so unreservedly gave away. The whole of the north-east coast was claimed by the Sultan of Sulu, and insofar as the local chiefs recognized any superior authority at all, they regarded him, and not the ruler of Brunei, as their overlord. The Baron therefore decided to visit Sulu in order to obtain a second cession, which would place the grants he had already received beyond doubt, and on January 22nd, 1878, the Sultan of Sulu transferred to him sovereignty over all the lands lying between the Seboekoe and Pandasan Rivers in return for an annual tribute of $\$ 5,000$. In addition His Highness appointed Overbeck "supreme and independent" ruler of the ceded territories and "Datu Berndahara and Raja of Sandakan", with powers as extensive as those already granted by the Sultan of Brunei. ${ }^{852}$

By virtue of these two cessions, Alfred Dent and his associates in London - Overbeck, failing to gain Austrian Government support, withdrew from the North Borneo enterprise early in 1879 - became the owners of a territory with a total area of over 30,000 square miles and a coastline of 850 miles. Their neighbours were the Spanish Government of the Philippines to the north-east, and the Netherlands Indian Government and Sarawak to the south. None of these powers was likely to welcome an addition to the ranks of existing sovereign authorities in the Indian Archipelago.

The first act of the new proprietors of northern Borneo was to set up administrative posts at various places around the coast. Initially.

051 Cf. E. de Waal, Onze Indische financiën, Deel viii, pp. 76-81.

652 Maxwell and Gibson, op. cit., pp. 158-60. 
these establishments were on a very small scale. ${ }^{653}$ The staff provided for Resident W. B. Pryer of Sandakan, for example, who was theoretically responsible for the whole area from Marudu Bay to the Dutch border, consisted of "a West Indian black named Anderson, a half-cast Hindoo named Abdul, and a couple of China boys". ${ }^{654}$ Consequently, when on September 4th, 1878, a Spanish warship steamed into Sandakan harbour to lay claim to north-eastern Borneo in accordance with the treaty concluded between the Philippines and Sulu the previous July, Pryer was not in a strong bargaining position. He refused to be cowed by mere superior force, however, and blandly rejected all his visitors' demands. Finding that argument was useless, the Spanish commander resorted to threats. Unless the Spanish flag was flying over Sandakan by twelve noon on the 6 th, he announced, he would order his guns to open fire. Pryer remained unimpressed, and the Spaniards, not wishing to provoke an international incident, had no option but to sail ignominiously away. ${ }^{655}$

The Philippine Government did not make any further attempt to assert their authority over north-eastern Borneo, although the British and Spanish home Governments carried on a fitful correspondence on the subject for some years. Eventually, by a protocol of March 7th, 1885, Spain abandoned all her territorial claims in Borneo and, in return, the United Kingdom and Germany recognized her undisputed sovereignty over the Sulu Archipelago, including Cagayan Sulu and Balabac. ${ }^{858}$ The Philippine Government did not long enjoy this unchallenged supremacy, however, for on August 20th, 1899, following the Spanish-American War, the Archipelago of Sulu became a possession of the United States.

The first move by the Dutch Government against the new British enterprise was less warlike, but more effective. In September 1879 a landing party from a Dutch gunboat hoisted the Netherlands flag at Batu Tinagat, more than forty miles up the coast from the Seboekoe River, and therefore well within the territory of North Borneo as defined in both the Brunei and Sulu cessions. With the limited resources available to him Pryer could do nothing to enforce his Government's territorial claims. He did, however, make a formal protest later to a visiting Dutch naval commander. ${ }^{657}$

053 North Borneo Herald and Official Gazette, March 1st, 1883.

054 Ada Pryer, $A$ Decade in Borneo, p. 14.

065 Ibid., pp. 29-31.

056 Saleeby, op. cit., pp. 371-3. Maxwell and Gibson, op. cit., pp. 174-7.

067 W. B. Pryer to H. O. Wickes (Comd. Z.M.S. Atjeh), July 4th, 1880. (F.O. 
To determine precisely where the north-eastern boundary of Dutch Borneo lay in 1879 was by no means easy. The Besluit of February 28th, 1846 (which instituted the short-lived 'Government of Borneo') fixed the frontier at $3^{\circ} 20^{\prime}$ North. In March 1850 it was raised by Kabinetsbeschikking to $4^{\circ} 20^{\prime}$, a parallel which intersects the coast well to the north of Batu Tinagat. But this decree was not made public, and Dutch maps and atlases produced between 1850 and 1879 continued to show various and conflicting boundaries. The 'Algemeene land- en zeekaart van de Nederlandsche overzeesche bezittingen', by J. W. Walter (1857), for example, retained the 1846 boundary of $3^{\circ} 20^{\circ} \mathrm{N}$. In J. Kuijper's map, 'Nederlandsch Oost-Indie' (1866), the boundary was marked to coincide with the Seboekoe River, while the 'Algemeene Atlas van Nederlandsch-Indië' (1870), by Baron Melvill van Carnbee and W. F. Versteeg, placed it north of Sebatik Island. There was general agreement that Dutch Borneo extended as far as the borders of the Sulu dependencies, but no one was sure just how far south these came.

The truth was that the Dutch had given little thought to the problem of defining their frontiers in eastern Borneo before the negotiation of the Dent-Overbeck concessions made this a matter of urgency, and even then, apart from the one gesture of sending a gunboat to Batu Tinagat, they did not try to hinder the spread of British influence southwards.

Inevitably, charges of apathy and negligence were levelled in the States-General at Baron van Goltstein, the Colonial Minister, but he was able to satisfy most of his critics by pointing out that, in the first place, the new undertaking was a private one, with no British Government support behind it, and that, secondly, no infringement of Dutch sovereign rights was involved, since the Dent-Overbeck concessions had been obtained from native princes who were not, and never had been, in alliance with the Kingdom of the Netherlands. ${ }^{858}$ Appropriate steps, he added, were being taken to ensure that Dutch boundaries in Borneo were adequately safeguarded.

The Dutch felt that there was no cause for alarm so long as North Borneo was being developed by a genuinely private concern, but they were anxious, nevertheless, to prevent Dent's undertaking from being

12/86): 'Koloniaal verslag van 1880 ', Staatscourant, Bijblad, 1880-1, Bijlage C,

p. 16. Sir Rutherford Alcock to Earl Granville, July 1st, 1882. (F.O. 12/86).

P. Adriani, Herinneringen, p. 181.

058 Nieuwe Rotterdamsche Courant, October 20th, 1879. 
used as a cloak for British imperialism. In November 1879 the Dutch Ambassador in London, Count van Bylandt, told the British Foreign Office that his Government would be obliged to make "reservations" should the Borneo enterprise "acquire the character of an establishment under an English Protectorate". Such an establishment, said van Bylandt, would be "contrary to the spirit which prevailed at the drawing up of the Treaty of the 17th March 1824". ${ }^{858}$

To this line of argument, by now very familiar, the British Government made their usual reply. Great Britain, van Bylandt was told, had never recognized that the Treaty of 1824 applied to Borneo. All the same, Her Majesty's Government had "no present intention" of extending protection to any part of that island, their object being "to promote the development of the resources of the country ... not to set up any dominion or to enter upon controversy with respect to territorial claims". ${ }^{600}$ With this somewhat evasive statement of British policy the Dutch were temporarily content.

Meanwhile Alfred Dent and his colleagues in London had been working hard to secure official British recognition for their undertaking. From the outset the North Borneo project received support from men of position and influence in the community, and Dent's standing with the Foreign Office was always high. In this respect he had a great advantage over the Raja of Sarawak. His associates included Mr. Richard Biddulph Martin, M.P., the eminent banker, Admiral Sir Henry Keppel, conqueror of the Borneo pirates, and Sir Rutherford Alcock, a retired diplomat with a long and distinguished career in the Far East. It was Alcock who succeeded in winning the co-operation of Sir Julian Pauncefote, the legal adviser and later the Permanent Under-Secretary to the Foreign Office, who became an untiring advocate and champion of the Dent enterprise and, holding the appointments he did, was well placed to see that his views were carried into execution.

Largely on Pauncefote's recommendation, the British Government indicated halfway through 1880 that they were prepared to confer a Royal Charter on Dent's undertaking. Advising Count van Bylandt of this decision, the Foreign Secretary, Earl Granville, gave an assurance that 'political considerations' were not involved, and that Great Britain

659 Baron van Lynden van Sandenburg to Count van Bylandt, November 11th, 1879. (P.P., 1882, LXXXI, p. 72).

000 Marquis of Salisbury to Mr. Stuart (reporting a conversation with Count van Bylandt), November 24th, 1879. (Ibid., p. 73). 
had no thought of annexing northern Borneo or of obtaining a protectorate over it. ${ }^{61}$ To the Dutch, however, the granting of a Royal Charter implied a degree of official British support for the undertaking that involved very definite 'political considerations'. Such a document, they maintained, "would seem to create a tie between the Company receiving and the Government bestowing it". ${ }^{62}$ Moreover, the enterprise would certainly not retain its private character if, as was proposed, the British Government reserved the right to share in the selection of the Company's chief officials, to control its foreign policy, and to veto the transfer of its territories to third parties. ${ }^{663}$ But all that the Foreign Office would promise was that the Dutch would be allowed to see a copy of the Charter before it was promulgated. ${ }^{864}$

Early the following year a 'British North Borneo Provisional Association, Limited' was formed for the purpose of acquiring Dent's interests. This association, the leading members of which were Dent himself, Alcock, Martin, Rear-Admiral R. C. Mayne, and W. H. M. Read, petitioned the Crown for a Royal Charter, on the understanding that when this privilege had been conferred, the Association would wind itself up and transfer its assets to a new body, to be known as the 'British North Borneo Company'. For reasons which will be examined later, this request was granted with little delay, and the North Borneo Company received its Charter under the Great Seal on November 1 st, $1881 .{ }^{685}$

True to their promise, the Foreign Office had sent a draft of the Charter to the Netherlands Government the previous July, inviting comments and suggestions. ${ }^{686}$ The Dutch immediately raised objections to several articles, claiming that ratification of the document as it stood would result in "profound disturbances in the present political relations in the north of the Island of Borneo". ${ }^{677}$ The British, however, refused to modify the text in any particular whatever. When the Charter was finally gazetted in November, the Dutch accepted the fait accompli,

661 Earl Granville to Mr. Stuart, July 21st, 1880. (Ibid., p. 75).

002 Baron van Lynden van Sandenburg to Count van Bylandt, August 2nd, 1880. (Ibid., p. 77).

663 Count van Bylandt to Earl Granville, April 8th, 1881. (Ibid., pp. 87-8).

004 Earl Granville to Mr. Stuart, May 27th, 1881. (Ibid., p. 88).

The text may be found in Maxwell and Gibson, op. cit., pp. 160-71.

${ }^{006}$ Earl Granville to Count van Bylandt, July 29th and August 8th, 1881. (P.P., 1882, LXXXI, pp. 88-9).

007 Baron van Lynden van Sandenburg to Count van Bylandt, August 11th, 1881. (Ibid., p. 92). 
but still maintained their original reservation, namely that the Treaty of 1824 prohibited "absolute British annexation" of the areas concerned. ${ }^{688}$

The problem now was to decide where the boundary-line between British and Dutch Borneo should be drawn. The Netherlands flag hoisted at Batu Tinagat in 1879 had been removed by the local inhabitants, but early in 1883 a Dutch controleur was stationed at the nearby village of Tawau, and Dutch warships, based on Tarakan Island, were patrolling the north-east coast. ${ }^{689}$ In September 1883, W. H. Treacher, the first Governor of North Borneo, determined to assert his territorial rights. Proceeding to the disputed area in his official launch, he steamed at full speed past two Dutch gunboats at anchor off Tawau, and landed on the south bank of the Seboekoe River, where he hoisted the North Borneo flag. A feu de joie was fired, the flag run down again, and the symbols - BNB 83 - carved on an adjacent mangrove tree. Returning to Tawau, Treacher exchanged visits with the gunboat commanders, and entertained the controleur to dinner. No sooner had he left the coast, however, than the Dutch chopped down his boundary mark. $^{670}$

An incident of this kind might easily have caused serious friction, but in 1884 the British and Dutch Governments very sensibly agreed to set up a joint commission to look into the whole boundary question on the spot. This commission began its work in July 1889, and its recommendations provided the basis for an Anglo-Dutch frontier convention signed in June $1891 .{ }^{671}$ As often happens in such cases, the boundary then laid down represented a compromise between the extreme claims of the two parties. At the time the geography of the interior of Borneo was not sufficiently well known for a boundary-line to be drawn in detail. The frontier which now divides the British colony of North Borneo from Indonesian Borneo was established by a joint Anglo-Dutch survey team in $1912{ }^{672}$

668 Mr. Rochussen to Count van Bylandt, December 12th, 1881. (Ibid., p. 102).

600 'Koloniaal verslag van 1883', Staatscouramt, Bijblad, 1883-4, Bijlage C, p. 16. China Telegraph, February 22nd, 1883. Sir Rutherford Alcock to Earl Granville, July 1st, 1882. (F.O. 12/86).

670 Governor Treacher to Sir Rutherford Alcock, September 10th, 1883. (F.O. 12/86).

671 'Convention between Great Britain and the Netherlands defining boundaries in Borneo', June 20th, 1891. (P.P., 1892, XCV, pp. 721-6. Maxwell and Gibson, op. cit., pp. 215-17).

672 See the Verslag der commissie tot uitzetting op het terrein van de tusschen 
The Dutch had not acquiesced willingly in the foundation of the British North Borneo Company, yet it cannot be said that they fought a full-scale diplomatic battle against it. By comparison with Ambassador Dedel's vigorous denunciations of the activities of James Brooke forty years before, the protests which Count van Bylandt was instructed to make were weak and hesitant. This was because most Dutch Liberals, whose party was in power at the time, openly admitted that the Netherlands had forfeited all right to oppose British expansion in northern Borneo by accepting the British treaty with Brunei of $1847 .{ }^{873}$ Van Bylandt's protests were probably intended more to pacify the Conservative party in the States-General than to impress the British Foreign Office. The Government of Sarawak, on the other hand, which had been trying for ten years to obtain from Brunei a much smaller cession of territory than the one negotiated by Baron van Overbeck, could not afford to take so detached a view.

From the beginning Raja Brooke was bitterly hostile to the North Borneo enterprise, and sought to defeat it by every means at his command. As soon as he learnt that the Dent-Overbeck concessions had been signed, he hurried to Brunei and harangued the Sultan and Court, pointing out that the negotiations had been completed without the approval, or even the cognizance, of the chiefs who ruled the ceded areas. ${ }^{674}$ Crossing the bay to Labuan, he told W. H. Treacher, then the Acting-Governor of the Colony, that the proposed company might easily be a total failure, that the Sultan, who was in his dotage, had no right to dispose of territory at all, and that he himself "intended to proceed up the coast and stir up the minds of the natives against the Baron". ${ }^{775}$ Finally, he wrote in protest to the Foreign Office against the "wholesale" character of the cessions, and claimed that, in any case, they were contrary to the Treaty of $1847 .^{678}$

In basing his case on this Treaty, which the Foreign Office had so often used to block the expansion of his own country, Brooke appeared to have an unanswerable argument. Overbeck was, after all, an Austrian

het Nederlandsche gebied en Britsch Noord-Borneo vastgestelde grens, Batavia, 1913.

873 See the debates in the Tweede Kamer of December 2nd, 1879, and December 5th-6th, 1881.

674 Brooke to Treacher, April 6th, 1878. Overbeck to Treacher, April 7th, 1878. (C.O. 144/50).

675 Acting-Governor Treacher to Lord Derby, April 17th, 1878. (Ibid.).

678 Brooke to Lord Derby, April 11th, 1878. (F.O. 12/53). 
baron, and therefore belonged to that category of 'foreign subjects' whose interference in the affairs of Brunei the Treaty was expressly designed to prevent. The cessions had been signed, moreover, without the British Government's knowledge, and this, too, was contrary to the Treaty. ${ }^{677}$ Yet, on receipt of Brooke's communication, Sir Julian Pauncefote commented sourly: "Raja Brooke is evidently incensed with jealousy of Raja Overbeck, but considering that his uncle annexed large portions of territory in defiance of the Treaty which he now cites against the Dent-Overbeck concession, the objection comes with bad grace from him". ${ }^{678}$ It was clear that, so far as Pauncefote was concerned, the Foreign Office would give no support to Sarawak in its coming battle with the influential North Borneo Company. Her Majesty's Government, Brooke was told, "have no reason to apprehend any proceedings on the part of the Company likely to affect injuriously the rights and liberties of the native populations, and they would regret to learn that ... any action had been taken by any Foreign Government prejudicial to the private interests of the British capitalists concerned". ${ }^{679}$ Here is further proof of the confusion of thought prevailing at this time concerning the status of Sarawak. When Brooke's plans to expand his own borders were being discussed, his country was refused recognition as an independent power. Now, he is apparently to be regarded as the head of a 'foreign government'!

In June 1878, sensing that Dent and Overbeck had more powerful backing than he had at first supposed, Brooke asked the Borneo Company, Limited, for a loan of $£ 20,000$. With this money he hoped to be able to bribe the Sultan of Brunei into granting him the entire northwest coast as far as Marudu Bay - thereby getting Overbeck and Dent "out of the way", as he put it. The Borneo Company agreed to supply the necessary funds, but the plan was not carried through. ${ }^{680}$ Brooke then decided to approach the Sultan once more regarding the

677 No stipulation was included to this effect in the Brunei cessions, but, illogically enough, British approval was made a pre-requisite of the cessions obtained from the Sultan of Sulu, with whom Great Britain had no treaty relations whatever. By the time he reached Sulu, Overbeck had become convinced that no enterprise in Borneo could survive without the goodwill of the British Government. When the second treaty was signed he therefore agreed to the insertion of a restrictive clause. (Tregonning, op. cit., p. 27 ).

678 Minute by Sir Julian Pauncefote on Brooke's letter of April 11th, 1878. (F.O. 12/53).

679 Marquis of Salisbury to Charles Brooke, June 3rd, 1878. (C.O. 144/51).

680 Minutes of the meetings of the Board of Directors of the Borneo Company, Ltd., June 16th, and August 14th, 1878. 
cession of Baram, and in December His Highness agreed to hand over the entire Baram River basin in exchange for a tribute of $\$ 4,200$ per annum. At once Brooke applied to the Foreign Office for permission to close the deal. ${ }^{681}$ His request was referred to the Colonial Office who, for their part, were inclined to support it. "Raja Brooke", remarked the Colonial Secretary, Sir Michael Hicks-Beach, "would appear to have strong claims for consideration, as his government has now been firmly established for many years, and has been conducted with success". ${ }^{882}$ But the Foreign Office were still reluctant to give their consent, ${ }^{683}$ and decided to seek advice in the matter from ActingGovernor Treacher of Labuan.

From Brooke's point of view, any reference to the Government of Labuan was bound to be disastrous. Not only had Treacher inherited the prejudices of his predecessors against Sarawak, but he had by this time all but thrown in his lot with the North Borneo Company, then in process of formation, and was soon to become that Company's first Governor. In forwarding his advice to the Foreign Office, therefore, Treacher mustered every argument he could against the extension of the authority of Sarawak to Baram. The Chinese of Labuan, he told the Foreign Secretary, were unanimously opposed to the cession. Labuan, they had said, was like a crab with its claws on the trading rivers of the opposite coast. Cut those claws away and the crab would die. The Brunei traders were equally hostile to the proposed transfer. If Baram passed to Sarawak, its trade would be diverted from Brunei to Kuching. Even the Sultan had no real desire to part with additional territory to Raja Brooke. He had agreed only because he was afraid that a refusal might lead once again to the withholding of the annual Sarawak tribute money. ${ }^{64}$

Most of these arguments contained little substance, for the trade of Baram was quite insignificant, but Treacher correctly described the attitude of the Sultan, who, throughout the whole of this period, was playing a double game. At one moment he would agree to cede Baram and at the next refuse his consent, at the same time appealing to the British Government for protection against Raja Brooke's aggressiveness. ${ }^{685}$ In all probability he was hoping that these tactics would enable

681 Charles Brooke to the Foreign Office, December 10th, 1878. (F.O. 12/52).

682 Colonial Office to the Foreign Office, February 9th, 1878. (Ibid.).

683 Foreign Office Minute of February 15th, 1879. (F.O. 12/52).

684 Treacher to Salisbury, May 3rd, 1879. (C.O. 144/52).

685 Sultan of Brunei to Treacher, May 18th, 1879. (Ibid.). 
him to extract from Brooke a particularly high price for the cession. Brooke soon realized this and in August 1879, when he received a note advising him that Her Majesty's Government were "not prepared to take any steps to induce the Sultan to act contrary to his feelings in the matter", gave orders for all negotiations in connection with Baram to cease. ${ }^{686}$

Meanwhile Alcock, Keppel, and others had been urging the Foreign Secretary, Lord Salisbury, to approve the granting of a Royal Charter to the proposed North Borneo Company. Salisbury was an early convert to this plan. Keppel persuaded him that northern Borneo would be useful to Great Britain as a naval base, and he was impressed by a warning from Alcock that unless some form of official British recognition were given to the Dent enterprise another European power might step in and occupy its territory. ${ }^{\mathbf{6 8 7}}$ A delay was caused, however, while the protests of Spain and the Netherlands were being considered, and early in 1880, before any decision had been reached, the Conservative administration to which Salisbury belonged was replaced by a Liberal Government under Mr. Gladstone.

Support for schemes involving an increase in Britain's imperial responsibilities was, of course, entirely against the Liberal tradition. In spite of this, the new Foreign Secretary, Earl Granville, the new Colonial Secretary, the Earl of Kimberley, and Gladstone himself all gave their blessing to the plan to confer a Charter on the North Borneo Company. The circumstances were held to be exceptional for two main reasons. ${ }^{688}$ In the first place, as Kimberley pointed out, the powers most likely to annex northern Borneo, if Britain took no action, were Spain, Germany, and the Netherlands. Of these, both Germany and Spain were 'protectionist'. If the country fell into the hands of either, British trade must inevitably suffer. As for the Netherlands, he personally would be "sorry to see an extension of their power". ${ }^{889}$ Secondly, as Gladstone and Lord Granville later explained in the Commons and Lords respectively, the cessions had already taken place, and a company to exploit them would certainly be formed whether a Royal Charter were conferred on it or not. Only by granting such a Charter could the Government make sure of being able to exercise

686 Marquis of Salisbury to Brooke, August 25th, 1879. Brooke to Salisbury, August 29th, 1879. (Ibid.).

687 Minute by the Marquis of Salisbury, October 11th, 1879. (F.O. 12/54). Cf. Tregonning, op. cit., pp. 44-5.

688 Cf. Sir Charles Dilke, Problems of Greater Britain, Vol. ii, pp. 165-6.

689 Minute by the Earl of Kimberley, July 15th, 1880. (C.O. 144/54). 
a restraining influence on the company's activities. "The Charter", said Granville, "confers no powers beyond those which Mr. Dent and his partners might have procured under the Companies Act", but, by conferring one, the Government had acquired a "negative control" over the domestic as well as the foreign policy of the new State of North Borneo. ${ }^{600}$

When the text of the Charter was made public in November 1881, therefore, it was found to consist almost entirely of restrictions on the Company's future policy and behaviour. Some of its articles bore witness to the workings of the Liberal conscience. Others revealed the Government's anxiety about the possibility of foreign intervention. The Company was always to remain "British in character and domicile" (Art. 3). It was forbidden to alienate its territories or possessions without the British Government's consent, and its relations with other nations were to be subject to the British Government's control (Arts. $4-6)$. It must take all practical steps to abolish slavery in its dominions, preserve native religion and customs, and administer justice with due regard to native law (Arts. 8-10). It must grant free facilities in its ports to ships of the Royal Navy (Art. 12), and the appointment of its principal representative in Borneo must receive the British Government's prior sanction (Art. 13). In return, the Company was apparently to receive nothing at all. The Charter made no reference to the provision of British military aid in time of war, or even to British moral support. Yet Dent and his friends were well satisfied. The dignity of a Royal Charter not only enhanced the prestige of their undertaking in the eyes of the inhabitants of Borneo, but improved its standing and, it may be added, the value of its shares, in the city of London. ${ }^{601}$

It is not always realized that the North Borneo Company was the first of the great chartered companies which figured so prominently in the story of British colonial expansion during the latter part of the nineteenth century. The Royal Niger Company was not chartered until 1886, the Imperial British East Africa Company until 1888, nor the British South Africa Company until 1889. To find a precedent for the British Government's action in issuing to the North Borneo Company a Royal Charter conferring exclusive sovereign rights over foreign

690 Speech by Earl Granville, March 13th, 1882. (Hansard, Vol. 267, Cols. 713-18). Speech by W. E. Gladstone, March 17th, 1882. (Ibid., Cols. 1188-96). Cf. Paul Knaplund, Gladstone and Britain's Imperial Policy, pp. 146-7.

691 Cf. Owen Rutter, British North Bormeo, p. 128. 
territory, it is necessary to go back to the seventeenth century. ${ }^{62}$ The East India Company, moreover, the greatest of all chartered companies of earlier days, had ceased to exercise governmental functions only a short time before (Act for the Better Government of India, August 1858), while the Hudson's Bay Company had similarly made over its remaining sovereign powers to the Crown in 1869 (Deed of Surrender, November 1869). The chartering of 'the North Borneo' was a reversal of the trend of history and marked the start of a new era in European commercial imperalism.

An immediate result of the granting of the North Borneo Charter was the removal of the British Government's ban on the acquisition of new territory by the Government of Sarawak. The Foreign Office realized that they could not continue to refuse Brooke permission to extend his frontiers, and at the same time approve the concessions which had been obtained by the North Borneo Company. In January 1882, therefore, the Government of Brunei was advised that Great Britain had now withdrawn her earlier objections to the transfer of the district of Baram, ${ }^{683}$ and five months later, much against his will, the Sultan ceded this long-disputed area to Raja Brooke. ${ }^{684}$

The successful negotiation of the Baram cession initiated a period of intense competition between Sarawak and North Borneo for control of the few Brunei territories now remaining. Agents dispatched to the Sultan's capital by Brooke and by Governor Treacher obtained numerous grants and concessions - some from the Sultan himself, some from the pengerans of the Court - and many of these, when compared later, were found to be conflicting. Brooke and Treacher promptly accused each other of 'piracy' and 'extortion', and angrily appealed to the British Government for redress.

The situation became even more confused when in August 1884 an armed revolt took place in the district of Limbang. By now the Brunei Government had become so weak and inefficient that it was forced to borrow twenty-four rifles from Labuan in order to defend the Sultan's palace, and peace was restored only through the intervention of a British gunboat. In May of the next year, following the death of Sultan Abdul Mumin of Brunei, another crisis occurred. The Pĕngeran Tĕmĕnggong, Hassim, was raised to the throne, but several

692 Cf. Pierre Bonassieux, Les grandes compagnies de commerce, pp. 517-27.

693 Administrator Leys to the Foreign Office, January 18th, 1882. (C.O. 144/56).

694 Charles Brooke to Administrator Leys, June 13th, 1882. (Ibid.). 
influential members of the Court and many provincial headmen refused to accept him as their lawful ruler. ${ }^{695}$

While chaos reigned in Brunei, the Foreign and Colonial Offices were doing their best to unravel the tangle of claims and counter-claims with which Brooke and Treacher had presented them. They found their efforts were greatly hindered, however, by the inaccuracy of the maps supplied by the two contestants. ${ }^{686}$ A certain amount of delay was therefore inevitable before an equitable solution to the problem could be worked out, and meanwhile tempers in Borneo had reached boilingpoint. "If something is not done soon", remarked a member of the Colonial Office in May 1885, "to cool the exasperation of Messrs. Brooke and Treacher, there will not be a pěngeran left in Brunei". ${ }^{697}$

The 'scramble for Brunei' coincided with a sudden quickening of the tempo of European colonial expansion in other parts of the Far East. It was during the years from 1883 to 1885 that the French, under the energetic leadership of Jules Ferry, made good their hold on Annam and annexed Tongking. The Germans were equally active; in addition to claiming huge areas in Africa, they hoisted the Imperial flag in the Caroline Islands and declared a Protectorate over north-eastern New Guinea. Either or both of these powers, the British realized, might soon be fishing in the troubled waters of northern Borneo. Of the two, Germany was considered the more dangerous. "Remember the new principles Bismarck has introduced into colonial politics", warned Lord Salisbury in October 1885. "He might as likely as not seize the balance [of Brunei] while we are waiting to see it reach the proper stage of decay". ${ }^{688}$ If the Germans were to obtain a foothold in Brunei, the strategic consequences would be serious, since from there they could threaten British trade with China. ${ }^{699}$

By 1886 it was clear that unless preventive action were taken soon, northern Borneo might pass into the German, or possibly the French, sphere of influence. From the British point of view, therefore, the two essentials were, first, to forestall any attempt by a foreign power to meddle with the area and, secondly, to bring to an end the prevailing anarchy in Brunei. In October of that year a joint Foreign and Colonial Office conference was called in London to consider how this twofold

\footnotetext{
695 C.O. 144/58-9. Baring-Gould and Bampfylde, op. cit., pp. 343-6.

${ }^{669}$ Minute by Sir Julian Pauncefote, October 15th, 1885. (F.O. 12/68).

687 Colonial Office to the Foreign Office, May 22nd, 1885, Private. (C.O. 144/60).

698 Minute by the Marquis of Salisbury, October 24th, 1885. (F.O. 12/68).

${ }^{699}$ Cf. Dilke, op. cit., Vol. ii, pp. 188-9.
} 
object might best be achieved. The Foreign Office had already put forward a suggestion that Brunei should become a British Protectorate, and it was now decided that a simpler and more effective course would be to extend formal British protection to North Borneo and Sarawak as well. By these means other nations would be given warning that they must not interfere, and relations between Brunei and its more powerful neighbours would be brought under closer British supervision. ${ }^{700}$

Early in 1887 Sir Frederick Weld, Governor of the Straits Settlements, was sent to Brunei to secure the Sultan's consent to this plan. His Highness gladly accepted British protection, but refused to comply with an additional suggestion from Weld that a Resident should be provided to advise on matters of domestic policy. ${ }^{701}$ No British Resident was appointed to Brunei until 1906. Sarawak and North Borneo also accepted the British offer, and by September 1888 Protectorate agreements had been negotiated between Her Majesty's Government and all three powers. ${ }^{702}$

The Sultan of Brunei welcomed a British Protectorate primarily because, without it, he had small chance of retaining his throne. It gave him, moreover, a far more effective guarantee than he had had before that Great Britain would come to his assistance if exorbitant demands for territorial concessions were made upon him. To the North Borneo Company, the chief advantage of a Protectorate was that it ensured full British support in time of war, while still leaving the management of all internal affairs in the hands of the officials of the Company. Similar benefits of greater stability and security were conferred on Sarawak, but to Raja Brooke a British Protectorate meant something more: it marked the successful conclusion of a battle which had been begun forty years before by the First White Raja. The British Government had now finally admitted that Sarawak was independent from the Sultanate of Brunei, and a sovereign state in its own right.

700 Foreign Office to the Colonial Office, October 29th, 1886. (F.O. 12/73).

Colonial Office Minute of the same date. (C.O. 144/62).

701 Sir Frederick Weld to Sir Julian Pauncefote, June 21st, 1887, Private. (F.O. 12/77).

702 P.P., 1888, LXXIII, pp. 181-5. 


\section{CONCLUSION}

Early in the nineteenth century, when the Dutch resumed possession of the South and West Coasts of Borneo, nothing appeared likely to hinder the eventual extension of their rule over the whole island. Nearly all the local princes were willing to accept them as protectors, and the British, their chief potential rivals among foreign colonial powers east of the Straits of Malacca, were still thinking in terms of 'trade, not territory'. Yet, as the century wore on, the Dutch seemed to be neglecting their opportunities. It was not until after the foundation of Sarawak by James Brooke in 1841 that they exerted their supremacy in the west and south, and not until after the negotiation of another large private concession by Dent and Overbeck in 1877 that they made a belated attempt to advance their frontier towards the far north-east.

To some extent this apparent slowness and hesitation on the part of the Dutch was the result of timidity and lack of vision at home. As in contemporary England, the belief that colonies were a source of weakness rather than strength had gained wide currency in Holland. Nevertheless, as the speeches and writings of many Dutch statesmen of the day clearly show, imperialism was by no means a forsaken cause either in The Hague or in Batavia, where, in some circles at least, the spirit of Jan Pieterszoon Coen was still very much alive. That the Dutch did not succeed in occupying the whole of Borneo while they had the chance was due not so much to lack of interest or enterprise as to the fact that at no time did they command the resources in men and materials needed to carry out so formidable a task.

After the restoration of the colonies one of the most serious problems confronting the Government of the Netherlands Indies was a shortage of trained colonial servants. Officials with experience under the East India Company had nearly all been dispersed during the disorganization of the Napoleonic period and facilities for training new ones were not immediately available. The position improved considerably after the establishment of the 'Koninklijke Academie' at Delft in 1842 although, even then, the chief beneficiary under the new system was Java. In 
the Outer Islands the shortage of competent officials, particularly of linguists, persisted until the end of the century.

Similar manpower difficulties beset the Dutch colonial army. Because the constitution of the Netherlands prohibited the sending of conscripts overseas, military detachments for the Indies had to be recruited by voluntary enlistment, and the better type of Dutchman did not often apply for the colonial service, not at any rate for service in the ranks. Unemployed and unemployables from half the countries of Europe, German and Swiss mercenaries, deserters from the armies of many different nations - these were the raw material of the Dutch colonial forces. When sent to the Indies, they proved to be "excellents en expédition, mais détestables en garnison" ${ }^{703}$ and did not make a favourable impression on the native populations among whom their duties lay. The countless riots and disturbances which figure so prominently in the history of the Chinese districts of western Borneo and which for so long hindered the spread of Dutch rule in that area were by no means all due to the 'persistent recalcitrance' of the local inhabitants. Much of the trouble was caused by the uncouth and provocative behaviour of the Dutch military garrisons.

Finally, the chronic political instability of nineteenth-century Borneo prevented overseas capital from being attracted to it in any appreciable quantity. The result was that the burden of economic development fell on the Government of the Netherlands Indies, which proved both unwilling and unable to accept the role of large-scale entrepreneur. During the period of the batig-saldo politiek, when the authorities in Batavia had to send substantial remittances home to the motherland every year, they could not afford to spend money freely in areas like western and southern Borneo, where no quick returns on investment could be guaranteed. Moreover, due partly to high production costs and partly to the general infertility of the soil, none of the attempts made by the Dutch Government to promote mining or agriculture in Borneo met with any considerable degree of success. The comparative prosperity which portions of the island enjoy today rests not on coal or gold, pepper, sago, or jungle products - the staple exports of the nineteenth century - but on petroleum and rubber, two commodities for which until fifty years ago the world had found very little use.

The failure of the Dutch to expand their rule to the north-west and north-east coasts left the way clear for exploitation by private indivi-

${ }^{703}$ Ch. et R. Pety de Thozée, Théories de la colonisation au XIX` siècle .., p. 162. 
duals. Of these the most successful were Raja Brooke of Sarawak and that trio of adventurers - an American speculator, an Austrian baron, and a London business-man - whose united efforts led to the foundation of the North Borneo Company. Like Dutch Borneo, however, the northern part of the island conferred small economic benefits on its possessors until after the development of the petroleum, rubber, timber, tobacco, and copra industries in more recent times.

In these circumstances it was not surprising that the British Government shared the hesitation of the Dutch about acquiring extensive territorial responsibilities in Borneo. So long as British merchants were assured of free access to the island's trade, neither the Foreign Office nor the Colonial Office could see any point in competing for possession of the island itself. Great Britain could not be persuaded to exert her supremacy along the northern coasts of Borneo until the attacks of the local Malay and Dyak pirates provoked more than usually forceful protests from commercial interests in England and in Singapore, and until, in the 1880's, the threat of interference by Spain, Germany, and France seemed likely to endanger her vital trade routes to China.

Throughout the nineteenth century strategic considerations were of paramount importance in determining the course of British policy in Borneo. They prevented the East India Company from acquiescing in exclusive Dutch sovereignty over the island between 1818 and 1824, provided James Brooke and Henry Wise with their strongest arguments for the creation of a British naval base and harbour of refuge at Labuan in 1846, induced Her Majesty's Government to grant a Royal Charter to the North Borneo Company in 1881 and led, finally, to the declaration of British Protectorates over North Borneo, Brunei, and Sarawak in 1888. During the present century the direct strategic significance of the island has declined, although its value to Great Britain as a source of 'strategic' commodities like oil and rubber is immense. But if, as at the moment seems likely, the frontier between the free and Communist worlds moves southwards from Indochina, northern Borneo may well take on a new importance as an outpost of the West in the Eastern Seas. 


\section{APPENDIX 'A'}

\section{A NOTE ON THE COLONIAL MSS PRESERVEd AT THE ALGEMEEN RIJKSARCHIEF}

The archives of the former Ministerie van Koloniën for the period 1813-1875 fall into two main sections:

(a) The records of the Ministry itself, and

(b) A series of volumes containing duplicates of the decrees (besluiten) of the Netherlands Indian Government at Batavia.

\section{A. THE RECORDS OF THE MINISTRY ITSELF}

\section{(i) The 'General Archives' (Gewoon archief)}

This series comprises the day to day incoming and outgoing correspondence of the Ministry on all matters not regarded at the time as confidential or secret. The 1,906 bundles which refer to the years $1814-49$ are located at the main repository at Bleijenburg 7, The Hague. Those referring to $1850-1900$ (5,250 bundles) are housed in an auxiliary repository at Schaarsbergen, near Arnhem, but may be consulted in The Hague by arrangement.

\section{(ii) The 'Secret Archives' (Geheim archief)}

During the nineteenth century many topics were classified as secret which, given similar circumstances, would probably not be placed in such a category today. As a result, all documents dealing with future plans (even when these were concerned with comparatively unimportant matters), all memoranda and reports containing expressions of opinion on past Government policies or actions, and all dispatches connected, however remotely, with the activities of foreign nations or individuals, seem to have found their way into the Geheim, rather than into the Gewoon, Archief. For the study of Dutch colonial policy the former is therefore by far the more valuable source.

The MSS which make up the Geheim Archief (1813-75) are arranged in approximately 195 bundles, known collectively as the 'Koloniën, Geheim, Resolutiën'. One of these bundles may contain any number from four or five to a hundred or more files, or 'dossiers', and 
the files themselves vary in size from one page to several scores of documents. Each file is identified by a date and a reference number. The date is normally that upon which the topic with which the file deals was closed by a decision or recommendation of the Minister of the Colonies. For example, the file marked ' 22 Januarij 1853 , No. 41/E, Geheim' contains a series of reports from the Resident of Pontianak to the Governor-General on the Chinese problem in western Borneo, the minutes of the deliberations of the Raad van Indie on the matter, decrees issued by the Governor-General and dispatches from him to the Minister of the Colonies on the same subject and, finally, under date January 22nd, 1853, a letter from the Minister to the Governor-General approving past actions and suggesting a course for the future. The reference number allotted to this letter, which corresponds to the number of the file, indicates that it was the 41 st secret letter originated by the Minister of the Colonies since the beginning of 1853.

At various times throughout the nineteenth century the clerical staff of the Ministry entered the secret decisions, transactions, and correspondence of their department in annual 'agendas' and 'indexes'. The 'agendas' record the 'acts' of the Minister in chronological order by years. The indexes list the same acts, but under subject-headings, such as, 'Borneo, Civil Administration, Outer Possessions', etc. In some years 'klappers' were also drawn up. These are alphabetical lists of proper names, titles, catch-words, etc., mentioned in the indexes, and provide a ready reference by page numbers to the index headings under which such names, titles or catch-words occur.

The comprehensiveness, and therefore the value for purposes of historical research, of these agendas, indexes, and klappers varies greatly, as the following table shows:

1814-29: Chronological lists provided for the years 1814-17 and 1824-29 only (though for the intervening years, 1818-23, the Gewoon Archief contains agendas which relate to 'secret' as well as 'ordinary' matters); indexes for the years 1826-29 only.

1830 49: Agendas, indexes, and klappers for the whole period.

1850 -57: Agendas only.

1858-69: Indexes are combined with those of the Kabinetsarchief (see below). Separate agendas.

1870 75: Both agendas and indexes are combined with those of the Kabinetsarchief.

Where indexes are lacking it is possible to work out the dates and numbers of the files which relate to a particular topic by going through the appropriate agendas.

In perhaps ten per cent of cases files identified by reference to the indexes and/or agendas turn out to be missing from the bundles. Whether they have been transferred to another series, borrowed, or simply lost is a matter for conjecture. 


\section{(iii) Other archives}

In addition to the 'Ordinary' and 'Secret' Archives, the records of the Colonial Ministry for 1815-75 include the following files and registers :

The Kabinetsarchief (1834-75), which contains the personal transactions and decrees of the Minister of the Colonies.

A series of registers giving details of the careers of colonial officials.

A nominal roll of all officers and other ranks who served in the East Indies during the course of the nineteenth century.

A list of all male Europeans in Java, compiled in the early 1820's.

30 private collections of documents, deposited with the Rijksarchief by officials who served in the East or by their descendants.

\section{B. COPIES OF EAST INDIAN DECREES}

Until 1836 the decrees (besluiten) of the Government of the Netherlands Indies were promulgated either by the Governor-General in Council (in Rade) or by the Governor-General alone (buiten Rade). By the Regeeringsreglement of that year, however, the Council of the Indies (Raad van Indië) was deprived of its executive function and became a purely advisory body.

Under the general title, 'East Indian Decrees', the following collections of documents are included:

(i) At the Rijksarchief

'Letters from Commissioners-General of the Netherlands Indies', 1816-28; 'Transactions and Decrees of Commissioners-General of the Netherlands Indies', 1816-17 and 1820-28; 'Secret Decrees of the Commissioners-General', 1816-19.

'Decrees of the Governor-General of the Netherlands Indies' (acting alone), $1814-49$.

'Secret Decrees of the Governor-General of the Netherlands Indies' (acting alone).

'Decrees of the Governor-General of the Netherlands Indies in Council', 1819-36.

'Secret Decrees of the Governor-General of the Netherlands Indies in Council', 1819-34.

'Decrees of the Governor-General of the Netherlands Indies' or 'East Indian Decrees', 1830-49.

(ii) At the Schaarsbergen Repository

'Decrees of the Governor-General of the Netherlands Indies' or 'East Indian Decrees', 1850-1932.

The records of the Ministry of the Colonies after 1900 are not open to public inspection. 
APPENDIX 'B'

\section{LIST OF SOURCES}

P R I M A R Y
A. MANUSCRIPT
(1) India Office Library
(a) East India Company Records

(i) Factory Records

\section{Borneo}

Vol. i : Miscellaneous Documents, 1648-1814.

Java

No. 40: Java Separate Dependencies Consultations, 29 Jan to 1 Jun 1814.

No. 41: Do, 27 Jul to 28 Dec 1814.

No. 42: Java Separate and Political Consultations, 6 Jan to 21 Jun 1815.

No. 60: Letters from Java, 24 Oct 1812 to 21 Sep 1813.

No. 61: Do, 11 Feb 1814 to 13 Dec 1816.

No. 62: Do, $20 \mathrm{Feb}$ and $23 \mathrm{Feb} 1817$.

No. 64: Misc. Memoranda on Java and the Eastern Islands. 1813-20.

No. 65: Miscellaneous Documents.

No. 67: Original Letters from Java, 19 Mar 1812 to $20 \mathrm{Jul}$ 1817.

No. 68: Original Enclosures to ditto, 1812-13.

\section{Straits Settlements}

No. 182: Letters received from Prince of Wales Island, 6 May 1818 to 6 Dec 1820.

No. 185: Abstracts of ditto, 12 Nov 1805 to 30 Jun 1830.

(ii) Dutch Records ' $A$ '

No. 11 : Miscellaneous Letters and Documents, Vol. vi, 17891818. 
No. 12 : Do, Vol. vii, 1816-17.

No. 13 : Do, Vol. viii, 1818-24.

No. 28 : Mission to Achin, 1818-19.

No. 28A: Dutch Factories in India. Singapore. 1818-19.

No. 29: Trade in the Eastern Archipelago, 1818-20.

No. 30 : Treaty with the Netherlands, $1823-4$, Vol. i.

No. 31 : Do, Vol. ii.

(iii) Home Miscellaneous Series

Vols. 542 and 673.

(b) Raffles Collection

II : MSS Eur. E. 104.

XI: MSS Eur. E. 109.

XIV: MSS Eur. C. 36.

(2) Public Record Office

(a) Colonial Office Records

(i) Labuan: Original Correspondence

C.O. $144 / 1-74$

Letters and dispatches from and to the Government of Labuan, domestic correspondence with other Government Departments, minutes and memoranda by Secretaries and Under-Secretaries of State and by Colonial Office officials, miscellaneous correspondence and documents. $1844-1900$.

C.O. $352 / 1-5$

Registers of Correspondence, 1849-1885.

(ii) Government of Labuan: Official Documents

C.O. $145 / 1-3$

Acts of the Legislative Council, 1849-1906.

C.O. 146

Blue Books, 1850-1906.

C.O. $404 / 1-5$

Entry Books : Dispatches from Secretaries of State and Domestic Letters, $1848-70$.

C.O. $487 / 1-2$

Ditto, $1871-87$. 
C.O. $434 / 1$

Minutes of the Legislative Council, 1849-89.

\section{(b) Foreign Office Records}

F.O. 12

Vols. 1-18, 22-31, 32A and B, 33A and B, 34A and B, 36-41, $43-47,50-1,57,59,61-6,69-70,74-5,78,80$.

Letters and dispatches, diplomatic and consular, from and to the British Consuls-General to the native states of Borneo, and at Sarawak and Brunei; domestic correspondence with other Government Departments; Foreign Office minutes and memoranda; correspondence with foreign governments, $1842-88$.

Vols. 19-21: 'Commission of Inquiry, Sir J. Brooke', 1853-4.

Vol. 35: 'Correspondence and Memoranda as to Sir James Brooke's proposals respecting Sarawak', 1852-69.

Vol. 42: 'Proposals for Establishment of a British Protectorate in Brunei, etc.', 1870-5.

Vol. 48: 'Claims of the Sultan of Brunei against the Oriental Coal Company', 1873-9.

Vol. 49: 'Case of the "Tony" Steam Launch', 1877-9.

Vol. 52: 'Cession of Territory (Baram) by the Sultan of Brunei to the Rajah of Sarawak', 1878-81.

Vols. 53-6: 'Dent and Overbeck Concession', 1877-8.

Vols. 58, 60, 67-8, 71-3, 76-7, 79, 81-2: 'British North Borneo Company', 1881-9.

Vol. 86: 'British North Borneo Company. Papers, Maps, etc., used in connection with the question of the Boundary of the Netherlands Possessions'.

F.O. 37

Vol. 421: 'Proceedings of the British and Dutch Authorities in the Eastern Seas', Vol. ii, 1862-64.

Vol. 450: Ditto, Vol. iii, 1865-7.

Vol. 487: Ditto, Vol. iv, 1868.

Vol. 488: Ditto, Vol. v, 1869-70.

F.O. 93

Part 16, No.1: Cession of Labuan, 1846.

No.2: Treaty with Brunei, May 1847.

No.3: Agreement with Brunei, November 1856.

F.0. 97

Vol. 249: 'Proceedings of the British and Dutch Authorities in the Eastern Seas', Vol. i, 1824-59. 
Vol. 251: 'Treaties between the Netherland Indian Government and Native Powers', Vol. i, 1843-61.

Vol. 253: Ditto, Vol. ii, 1841-65.

Vol. 254: Ditto, Vol. iii, 1863-5.

Note: In footnote references I have sometimes given a volume in the C.O. 144 series as my authority for a letter to the British Foreign Office. The explanation is as follows :

After 1861, when the posts of Governor of Labuan and ConsulGeneral for Borneo were amalgamated, it became standard practice for the Governors of Labuan to send to the Colonial Secretary copies of all correspondence addressed by them in their consular capacity to the Foreign Office. Such copies, whatever the nature of their subject matter, were automatically filed by the Colonial Office staff in the Labuan series (C.O. 144). Many of the original letters, however, particularly those dealing with relations with foreign countries, are missing from F.O. 12; some may have been lost, but most were probably filed at the time in other F.O. series.

(3) Algemeen Rijksarchief

(a) Records of the Ministry of Foreign Affairs

'Buitenlandsche Zaken, Nos. 3133-4 (Retroacta A, No.60, betrekkelijk Borneo)'.

Two large bundles of documents which comprise the records of the Dutch Ministry of Foreign Affairs in regard to Borneo from 1838-47 (Bundle 3133) and from 1847-70 (Bundle 3134). The documents have been extracted at an unspecified date from the Ministry's running files. They give a valuable picture of the Dutch Government's reaction to the arrival in Borneo and subsequent activities of Sir James Brooke, and may be regarded as the Dutch counterpart of the Series F.O. 12 in the British Public Record Office.

\section{(b) Records of the Ministry of Colonies}

(i) 'Register der Handelingen en Besluiten van Commissarissen Generaal over Nederlandsch Indien', 1816.

(ii) 'Afschriften en Besluiten: Commissarissen Generaal over Nederlandsch Indie', 1817.

(iii) 'Geheim verbaal', 1816-17.

(iv) 'Instructiën', 1816-17. (Kol. 813.)

(v) 'Koloniën, Geheim, Resolutiën', 1841-75. 
The above is a list of the basic Dutch MS material used during the writing of the present study. In addition a number of documents were found for me in other collections by the staffs of the Rijksarchief and the Ministerie voor Uniezaken en Overzeesche Rijksdelen. These are as follows :

(i) 'Overzicht van de maatregelen in het verleden op Borneo genomen ten opzichte van de inboorlingen en Chinezen'. (Kol., Oct 14th, 1844, No. 25.)

(ii) Dispatch from the Dutch Ambassador in Washington on American relations with Brunei, dated Oct 27th, 1845. (Kol., Dec 3rd, 1845, L A, No. 2.)

(iii) 'Brow : 1844'. (A report by J. van Capellen, dated Mar 31st, 1846, on the East Coast district of Berouw.)

(iv) Various reports on Borneo. (Kol., May 11th, 1846, No. 13.)

(v) Letter from Governor Weddik to the Governor-General, Sep 27th, 1846. (Kol., 730\% $/ 15$.)

(vi) Correspondence regarding English plans in Borneo. (Kol., May 24 th, 1848, No. 9.)

(vii) 'Briefwisseling over de reorganisatie van het bestuur van Borneo'. (Kol., May 11th, 1849, L' A, No. 1.)

(viii) 'Memories van overgave' (reports compiled by outgoing Residents of Dutch Borneo, South and Eastern Division, for the benefit of their successors) dated: Apr 30th, 1877; Mar 2nd, 1880 (Mailrapport 232); May 19th, 1891 (Mailrapport 692); Apr 23rd, 1894 (Mailrapport 542).

(4) Miscellaneous

(i) The Aberdeen Papers

(British Museum, Add. MSS 43188 and 43200).

These volumes contain a number of letters which passed between the Earls of Aberdeen and Clarendon in connection with the Commission of Inquiry into the position of Sir James Brooke, held at Singapore in 1854 .

(ii) Borneo Company Minutes

(Vols. i-viii : June 9th, 1856, to Sept 28th, 1899).

The minutes of the regular meetings of the directors of the Borneo Company, Limited, preserved at the Head Office of the Company, Sackville House, 153-9, Fenchurch Street, London, E.C. 3. 
B. PUBLISHED SOURCES

(1) Official Publications

(a) British Parliamentary Debates

Ser. iii

Vol. 97, Cols. 699-700: 'Settlements in Labuan and Borneo'.

Vol. 101, Cols. 311-14 : 'Supply - Labuan'.

Vol. 108, Cols, 661-6 : 'Pirates (Head Money) Repeal Bill'.

Vol. 109, Cols. 1219-21 : 'Borneo - Pirates', and 'Pirates (Head Money) Repeal Bill'.

Vol. 111, Cols. 294-311: 'Navy Estimates - Miscellaneous Series'.

Vol. 112, Cols. 1300-26 : 'Alleged Piracy off Borneo'.

Vol. 113, Cols. 106-22 : 'Supply - Labuan'.

Vol. 117, Cols. 3-6 : 'Sir James Brooke - Borneo'.

Vol. 118, Cols. 436-504: 'Borneo - Sir James Brooke'; Cols. 679-80 : 'Supply - Labuan'.

Vol. 119, Cols. 1257-61 : 'Borneo - Sir James Brooke'.

Vol. 120, Cols. 43-5 : 'Borneo'.

Vol. 122, Cols. 604-11 : 'Supply - Labuan'

Vol. 125, Cols. 723-6 : 'Sir James Brooke - Piracy in Borneo'.

Vol. 126, Cols. 909-10 : 'The Borneo Pirates'.

Vol. 267, Cols. 708-24 : 'British North Borneo Company (Charter). - Observations'.

Cols. 1148-1230: 'British North Borneo Company (Charter). - Resolution'.

Ser. iv

Vol. 5, Cols. 1808-19 : 'British North Borneo Company'.

\section{(b) British Parliamentary Papers}

(Command Papers in square brackets ; Sessional Papers in parentheses.)

'Estimate of the Amount of Aid required to defray the Charge of Labuan', 1847-54, 1857-69.

'Reports by Her Majesty's Consuls on the Trade and Commerce of Brunei', 1858-88. (Irregular.)

'Reports by Her Majesty's Consuls on the Trade and Commerce of Sarawak', 1863-72. (Irregular.)

'Reports exhibiting the Past and Present State of Her Majesty's Colonial Possessions' - Labuan, 1849-90.

'Statistical Tables relating to the Colonial and Other Possessions of the United Kingdom' - Labuan, 1854-90. 


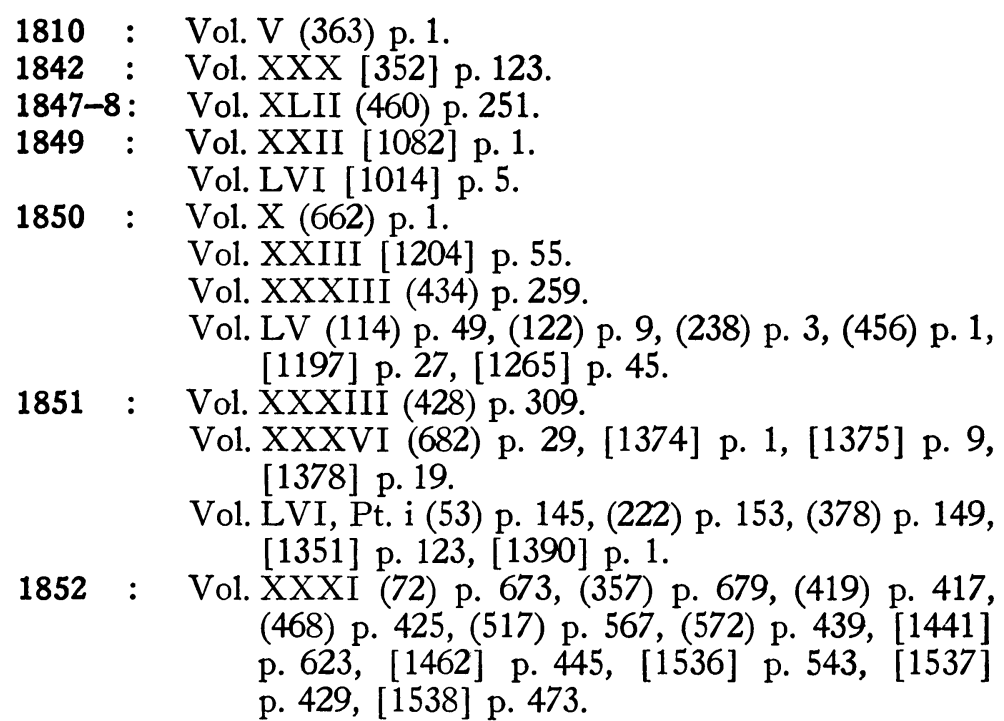

1852-3 : Vol. LXI (4) p. 281, (55) p. 235, (81) p. 253, (157) p. $335,(249)$ p. $247,(266)$ p. 299 , (281) p. 333 , (317) p. $331,(717)$ p. $321,(770)$ p. $317,(967)$ p. 277, [1599] p. 343.

1854 : Vol. XLII (12) p. 433, (298) p. 497.

1854-5: Vol. XXIX [1976] p. 1.

1872 : Vol. XLIII (90) p. 567.

1878-9: Vol. LXXVII [c. 2181] p. 171.

1882 : Vol. LXXXI [c. 3108] p. 315, [c. 3109] p. 59.

1887 : Vol. LII (131) p. 645.

1888 : Vol. LXXIII [c. 5617] p. 179.

1892 : Vol. XCV [c. 6553] p.721.

(c) Dutch Parliamentary Papers

'Koloniale Verslagen', 1849-90.

(Published in the Staatscourant, Bijblad, 1851/2 to $1890 / 1$.)

(d) Periodicals and Gazettes

Almanak van Nederlandsch-Indië.

Bataviasche Koloniale Courant.

Java Government Gazette.

North Borneo Herald and Official Gazette.

Sarazera Gazette.

Staatsblad van Nederlandsch-Indië.

(e) Miscellaneous

Brunei: 1950

North Borneo : 1950

Sarawak: 1950

Colonial Reports.

London, H.M.S.O., 1951. 
Dutch Borneo. (Foreign Office Handbook No. 84.) London, H.M.S.O., 1920.

Handbook of British North Borneo. (Compiled for the Colonial and Indian Exhibition of 1886.) London, Clowes, 1886.

Handbook of the State of North Borneo. London, British North Borneo (Chartered) Company, 1929.

Overeenkomsten met de zelfbesturen in de Residentie Westerafdeeling van Borneo. 1856-1900.

Overeenkomsten met de zelfbesturen in de Residentie Zuid-en Oosterafdeeling van Borneo. 1862-1900.

$V$ erslag der commissie tot witzetting van de tusschen het Nederlandsch gebied en Britsch Noord-Borneo vastgestelde grens. Batavia, Landsdrukkerij, 1913.

(2) Collections of Documents

BAKer, A. C. 'Some account of Anglo-Dutch relations in the East at the beginning of the nineteenth century', JRASSB, 1913, pp. 1-168.

ChIJs, J. A. vAN DER. Nederlandsch-Indisch plakaatboek, 1602-1811. Batavia, Landsdrukkerij, 1885-1900. $17 \mathrm{dln}$.

Colenbrander, H. T. Gedenkstukken der algemeene geschiedenis van Nederland van 1795 tot $1840.8^{\circ}$ Deel, $1^{\circ}$ stuk. 's-Gravenhage, Nijhoff, 1915.

Cowan, C. D. 'Early Penang and the rise of Singapore, 1805-32', $J R A S M B$, March 1950.

Deventer, M. L. van. Het Nederlandsch gezag over Java en onderhoorigheden sedert 1811: eerste deel - 1811-20. 's-Gravenhage, Nijhoff, 1891.

Elout van Soeterwoude, P. J. Bijdragen tot de geschiedenis der onderhandelingen met Engeland betreffende de overzeesche bezittingen, 1820-1824. (Getrokken uit de nagelaten papieren van wijlen den Minister van Staat Elout.) 's-Gravenhage, Nijhoff, 1865.

Maxwell, Sir William G. and Gibson, W. S. Treaties and Engagements affecting the Malay States and Borneo. London, Comd., 1924.

Rutter, E. Owen (Ed.). Rajah Brooke \& Baroness Burdett Coutts. (Consisting of the Letters from Sir James Brooke, first White Rajah of Sarawak to Miss Angela (afterwards Baroness) Burdett Coutts.) London, Hutchinson, 1935.

Selection from Papers relating to Borneo and Proceedings at Sarazeak of James Brooke, Esq., now Agent for the British Government in Borneo, A. London, Robson, Levy \& Franklyn, 1844-6. (Compiled by Henry Wise.)

Templer, John C. (Ed.). The Private Letters of Sir James Brooke, K.C.B., Rajah of Sarawak ... London, Bentley, 1853. 3 vols.

Webster, Sir Charles K. (Ed.). British Diplomacy, 1813-1815. London, Bell, 1921. 
(3) Reports and Narratives by Participants in Events

Belcher, Captain Sir Edward. Narrative of the Voyage of H.M.S. Samarang, During the Years 1843-46; Employed Surveying the Islands of the Eastern Archipelago... London, Reeve, 1851. 2 vols.

Brooke, Sir James. 'Expedition to Borneo', Journ. Roy. Geog. Soc., 1838, pp. 443-8.

- $A$ Letter from Borneo, with Notices of the Country and its Inhabitants. London, Seeley, 1842.

Statement relative to Sarawak. Privately printed, 1863.

A Vindication of his Character and Proceedings.... London, Ridgway, 1853.

[For Sir James Brooke's private journals, see Keppel, Captain the Hon. Henry, and Mundy, Captain Rodney; for his private correspondence, see Rutter, E. Owen, and Templer, John C.]

CowIE, W. C. 'North Borneo and how it became British', London and China Express, November 27th, 1908. (Supplement.)

Dalton, John. 'Papers on Borneo', Moor's Notices, pp. 15-78.

Dewall, $H$. von. 'Aanteekeningen omtrent de Noord-oostkust van Borneo', $T T L V$, Deel iv (1855), pp. 423-58.

'Matan, Simpang, Soekadana, de Karimata-eilanden en Koeboe', $T T L V, 1862$, pp. $1-146$.

Dungen Gronovius, D. J. van DEN. 'Over de goudgraverijen in de afdeeling Sambas', TvNI, 1847, ii, pp. 385-98.

'Verslag over de Residentie Borneo's Westkust, 1827-1829', $T v N I, 1871$, i, pp. $10-40$.

Forbes, Lieutenant F. E. Five Years in China; from 1842 to 1847. With an account of the Occupation of the Islands of Labuan and Borneo by Her Majesty's Forces. London, Bentley, 1848.

Francts, E. A. 'Westkust van Borneo in 1832', TvNI,1842, ii, pp.1-34.

Gaffron, Heinrich von. 'Beschrijving van het westelijke gedeelte van de Zuid- en Oosterafdeeling van Borneo (de afdeeling Sampit en de Zuidkust)', $B T L V, 1860$, pp. 243-346.

_ 'Verslag over de goudmijnen in het westelijke gedeelte van Tanah Lawut (eiland Borneo)', NTvNI, 1851, pp. 30-40.

GalloIs, J. G. A. 'Korte aantekeningen, gehouden gedurende eene reis langs de Oostkust van Borneo, verrigt op last van het Nederlandsch Indisch Gouvernement', BTLV, 1855, pp. 221-63.

GrAaF, G. M. van DE. 'Verslag eener reis naar Montrado gedaan in het jaar 1844', TvNI, 1847, iii, pp. 63-75.

Keppes, Captain the Hon. (later Admiral of the Fleet Sir) Henry. The Expedition to Borneo of H.M.S. Dido for the Suppression of Piracy: with Extracts from the Journal of James Brooke, Esq., of Sarazeak (now Agent for the British Government in Borneo). London, Chapman \& Hall, 1846 (2nd. Ed.). 2 vols.

- Idem. (A proof copy of the first (ie. suppressed) printing, preser- 
ved in the British Museum; autographed by Henry Wise : "Memo. Suppressed 10th Sept. 1845".)

— A Sailor's Life under Four Sovereigns. London, Macmillan, 1899. 3 vols.

- A Visit to the Indian Archipelago in H.M. Ship Maeander with Portions of the Private Journal of Sir James Brooke, K.C.B. London, Bentley, 1853. 2 vols.

Kervel, T. A. C. van. 'De hervorming van den maatschappelijken toestand ter Westkust van Borneo', (Report of August 25th, 1848), TvNI, 1853, i, pp. 186-98.

Lijnden, D. W. C. baron van. 'De verhouding in welke het Gouvernement staat tot de Chinezen en Dajaks op de Westkust van Borneo en voornamelijk op Sambas', TvNI, 1853, i, pp. 171-86.

Mundy, Captain Rodney. Narrative of Events in Borneo and Celebes down to the Occupation of Labuan. London, Murray, 1848. 2 vols.

'Rapport der speciale kommissie benoend bij koninklijk besluit van 25 Februarij, no. 26, aan den minister van Koloniën', 24 Julij 1850, NTvNI, 1851, pp. 80-107.

Rochussen, J. J. Toelichting en verdediging van eenige daden van mijn bestuur in Indië... 's-Gravenhage, van Cleef, 1853.

Toвias, J. H. 'Beschrijving van Banjer Massing', De Nederlandsche Hermes, IIIe Jaarg., No. 13, pp. 1-38.

_- 'De Westkust van Borneo', De Nederlandsche Hermes, IIIe Jaarg., No. 12, pp. 1-99.

WedDIK, A. L. 'Beknopt overzigt van het rijk van Koetei op Borneo', Indisch Archief, 1849, i, pp. 78-105, 123-70.

Zwager, J. 'Het rijk van Koetei op de Oostkust van Borneo in het jaar 1853', TvNI, 1866, ii, pp. 231-66.

(4) Contemporary Pamphlets, Articles a n $\mathrm{d}$ oo ks

Adderley, C. B. (Baron Norton). Review of 'The Colonial Policy of Lord J. Russell's Administration', by Earl Grey, 1853; and of Subsequent Colonial History. London, Stanford, 1869.

American Trading Company of Borneo: Organized under special concession from His Highness the Sultan of Borneo and the general laws of the State of New York. New York, Bryant, 1868.

Anderson, John. Acheen and the Ports on the North and East Coasts of Sumatra; with Incidental Notices of the Trade in the Eastern Seas, and the Aggressions of the Dutch. London, Allen, 1840.

Appel de la Hollande à la justice et à la raison de la Grande-Bretagne. La Haye, van Hoogstraten, 1836.

Assey, Charles. On the Trade to China and the Indian Archipelago: with Observations on the Insecurity of the British Interests in that Quarter. London, Rodwell \& Martin, 1819.

Audiganne, A. 'Politique coloniale de l'Angleterre: expédition de Bornéo', Revue des Deux Mondes, Avril-Juin 1846, pp. 645-70. 
'Berichten omtrent den zeeroof in den Indischen Archipel', TTLV. (Recurrent article.)

'Bijdrage tot de kennis der binnenlandsche rijken van het westelijke gedeelte van Borneo', TvNI, 1849, i, pp. 338-56.

'Borneo', in Bijdragen tot de kennis der Nederlandsche en vreemde koloniën bijzonder betrekkelijk de vrijlating der slaven, 1845. Deel ii. Utrecht, van der Post, 1846.

'Borneo en de heer Rochussen', TvNI, 1854, i, pp. 26-34.

Borneo Question, The. Compiled from the Singapore Free Press, and other sources. Singapore, 1854.

Brooke, Captain J. Brooke. A statement regarding Sarawak. Privately printed, 1863.

Chamerovzow, Louis A. Borneo Facts versus Borneo Fallacies. London, Gilpin, 1851.

Crawfurd, John. 'Memorandum on the proposed British settlement on the north-west coast of Borneo', in Keppel, Dido, ii, pp. 212-26.

Dalrymple, Alexander. A Full and Clear Proof that the Spaniards can have no Claim to Balambangan. London, printed for the author, 1774.

— General Collection of Nautical Publications. London, Bigg, 1783. Oriental Repertory. London, printed for the author, 1793 and 1808. 2 vols.

- A Plan for Extending the Commerce of This Kingdom, and of the East India Company. London, printed for the author, 1769.

Davidson, G. F. Trade and Travel in the Far East. London, Madden \& Malcolm, 1846.

DoRen, J. B. J. van. Bij zeren ligt de schuld van de gruwelijke gebeurtenissen te Bandjermasin...? Amsterdam, Sybrandi, 1861.

Foggo, George. Adventures of Sir James Brooke, K.C.B., Rajah of Sarawak, "Sovereign de facto of Borneo Proper", late Governor of Labuan. London, Wilson, 1853.

Gladstone, W. E. 'Piracy in Borneo and the operations of July 1849', The Contemporary Review, 1877, pp. 181-98.

Grey, Earl. The Colonial Policy of Lord John Russell's Administration. London, Bentley, 1853. 2 vols.

Hasselman, J. J. en Vlissingen, F. U. van. Beschouwingen omtrent de exploitatie der Wester-afdeeling van Borneo. Amsterdam, Zweesaardt, 1859.

HoËveLL, W. R. baron van. 'Laboean, Serawak, de Noord-oostkust van Borneo en de Sulthan van Soeloe', TvNI, 1849, i, pp. 66-83, $97-111,237-42$.

- 'Onze roeping op Borneo', TvNI, 1852, ii, pp. 187-94.

Hume, Joseph. A Letter to the Right Honourable the Earl of Malmesbury ... relative to the Proceedings of Sir James Brooke, K.C.B., etc., etc., etc., in Borneo. London, printed for the author, 1853.

LAUTS, G. Onderzoek naar geest en strekking van het traktaat van den 17 den Maart 1824 ... Amsterdam, Zweesaardt, 1837. 
Lindsay, H. H. The Eastern Archipelago Company and Sir James Brooke. (n.d.)

Lith, P. A. van DER. 'Het Noord-Borneo tractaat', De Gids, 1891, iv, pp. $444-78$.

Logan, J. R. 'Area of the Indian Archipelago and of the islands claimed by the Netherlands', Journ. Ind. Arch., 1848, pp. 176-81.

- 'The present condition of the Indian Archipelago', Journ. Ind. Arch., 1847, pp. 1-21.

'Maatschappij tot bevordering van Mijnontginning in NederlandschIndië', TvNI, 1856, i, pp. 312-13; 1857, ii, pp. 324-6.

Melvill de Carnbee, $P$. 'Tableaux généraux de la population des Indes-Orientales et des possessions néerlandaises dans l'archipel Indien-Oriental', Moniteur des Indes, 1846/7, i, pp. 69-70.

Moor, J. H. (ED.). Notices of the Indian Archipelago and Adjacent Countries... Singapore, 1837.

Muntinghe, H. W. 'De bevestiging van het Nederlandsch gezag op Borneo en de vermeerdering der inkomsten van dat eiland voor de schatkist', (Report of August 31st, 1821), TvNI, 1850, ii, pp. $160-200$.

'Nederlands rechten op Borneo', De Indische Gids, 1889, i, 62-5.

'Nederlandsch-Indië in 1817', TvNI, 1861, i, pp. 271-300, 339-71.

Newbold, T. J. Political and Statistical Account of the British Settlements in the Straits of Malacca ... London, Murray, 1839. 2 vols.

Quarles van Ufford, J. K. W. 'De Edinburgh Review over de koloniale politiek van Nederland', TvNI, 1852, ii, pp. $281-8$.

'Quelques considérations et souvenirs historiques à l'occasion de la prise de possession de Laboean par l'Angleterre', Moniteur des Indes. $1846 / 7$, pp. 295-318.

'Quelques mots en réponse aux attaques des journaux anglais contre la Néerlande', Moniteur des Indes, 1847/8, i, pp. 217-32, 271-88.

Rajah Brooke and Borneo. London, Chambers, 1850.

Raffles, Sir Thomas Stamford. The History of Java. London, Black, Parbury \& Allen, 1817. 2 vols.

- Statement of the Services of Sir Stamford Raffles. London, Cox \& Baylis, 1824.

RobidÉ van DER AA, P. J. B. C. 'De omvang van Nederlands rechten in den Indischen archipel in verband met de Londensche traktaten van 1814 en 1824, en met de nederzetting der Engelschen in Noord-Borneo', Verslagen der Vergaderingen van het Indisch Genootschap, 1881, pp. 1-28.

'Statistique coloniale: les Indes hollandaises en 1848: lère partie: Java, Bornéo, Célèbes. (ii) Traité de 1824. Question de Bornéo', Moniteur des Indes, 1848/9, i, pp. 346-9.

Steyn Parvé, D. C. De handelingen van Sir James Brooke op Borneo... Haarlem, Weeveringh, 1859.

Thorn, Major William. Memoir of the Conquest of Java ... London Wilks, 1815. 
Valentyn, Françors. 'Beschryving van het eiland Borneo, en onzen handel aldaar', in Oud en Nieure Oost-Indien, Deel 3, Stuk 2, pp. 236-52. Dordrecht, van Braam, 1726.

'W. N.' Borneo: Remarks on a Recent 'Naval Execution'. London, Wilson, 1850.

Wijnen, R. 'Noord-Borneo en het tractaat van 1824', TvNI, 1889, i. pp. 161-99.

\section{SECONDARY}

\section{A. BIBLIOGRAPHIES}

Annual Lists and General Index of the Parliamentary Papers relating to the East Indies published during the Years 1801 to 1907 inclusive. Ordered to be Printed, March 31st, 1909.

Bibliography of Indonesian Peoples and Cultures, compiled by Raymond Kennedy. (Yale Anthropological Studies, Vol. iv.) New Haven, Yale University Press, 1945.

Catalogus der Bibliotheek van het Koninklijk Bataviaasch Genootschap van Kunsten en Wetenschappen ( $F-G$ : Geschiedenis). Bandoeng, $\mathrm{Nix}, 1940$.

Catalogus van de boeken en kaarten uitmakende de Bibliotheek van het Departement van Koloniën. 's-Gravenhage (published intermittently).

'Contribution to Malayan Bibliography, A' compiled by N. B. Dennys. $J R A S S B, 1880$, pp. 69-123, 225-72.

Far Eastern Bibliography. Published periodically for the Far Eastern Association, Inc., by Cornell University Press, Ithaca, New York.

Proeve eener Ned. Indische Bibliographie, 1695-1870, compiled by J. A. van der Chijs. Batavia, Bruining \& Wijt, 1875.

Repertorium op de koloniale litteratuur, of systematische inhoudsopgaaf van hetgeen voorkomt over de koloniën... in mengelwerken en tijdschriften... uitgegeven in Nederland en zijne overzeesche bezittingen.

1595-1865, compiled by J. C. Hooykaas. Amsterdam, van Kampen, 1880. $2 \mathrm{dln}$.

1866-1905, compiled by A. Hartmann. 's-Gravenhage, Nijhoff, 1895, 1901, 1906. 3 dln.

1906-1925, compiled by W. J. P. J. Schalker and W. C. Muller. 's-Gravenhage, Nijhoff, 1912, 1917, 1923, 1928. 4 dln.

1926-1932, compiled by D. Sepp. 's-Gravenhage, Nijhoff, 1934, 1935. $2 \mathrm{dln}$.

Subject Catalogue of the Library of the Royal Empire Society..., compiled by Evans Lewin. London, Royal Empire Society, $1930-7.4$ vols. 


\section{B. UNPUBLISHED DISSERTATIONS}

EDgELL, T. C. P. 'English trade and policy in Borneo and the adjacent islands, 1667-1786'. M. A. Thesis, University of London, 1935.

Tregonning, K. G. 'The administration and development of North Borneo by the British North Borneo Company, 1881-1903'. B. Litt. Thesis, University of Oxford, 1952.

Note: Since it is the practice in Holland for academic dissertations to be published before submission, Dutch dissertations consulted are included in the section immediately following.

\section{ARTICLES AND BOOKS}

Angoulvant, Gabriel Louis. Les Indes néerlandaises: leur rôle dans l'économie internationale. Paris, Monde Nouveau, 1926. 2 vols.

'B.' 'Sambas', De Indische Mercuur, 1896 (No. 12), pp. 170-1.

BANKS, E. 'The natives of Sarawak', JRASMB, August 1940, pp. $49-54$.

Baring-Gould, S. and Bampfylde, C. A. A History of Sarawak under its Two White Rajahs: 1839-1908. London, Southeran, 1909.

Bastian, Adolf. Indonesien, oder die Inseln des Malayischen Archipels. (Lief. 4, 'Borneo und Celebes'.) Berlin, Dümmlers, 1889.

Bastin, John. 'Raffles and British Policy in the Indian Archipelago, 1811-16', JRASMB, May 1954, pp. 84-119.

Baud, J. C. 'De Bandjermasinsche afschuwelijkheid: nauwkeurige geschiedenis van het etablissement van den beruchten A. Hare, getrokken uit officieele stukken', $B T L V, 1860$, pp. 1-25.

Blok, Petrus Johannes. History of the People of the Netherlands. New York, Putnams, 1898-1912. 5 vols.

Bock, Carl. The Head-hunters of Borneo. London, Sampson Low, 1881.

Bonnassieux, Pierre. Les grandes compagnies de commerce. Paris, Plon, 1892.

'Borneo Company, Limited, The', China Express and Telegraph. November 29th, 1928.

Bosch, D. W. Geschied-en aardrijkskundige beschrijving van Neêrlands Oost- en West-Indische bezittingen. Amsterdam, Schalekamp, 1844.

Boucher, F. The Indian Archipelago. London, Jones \& Causton, 1857. Boulger, Demetrius C. The Life of Sir Stamford Raffles. London, Marshall, 1897.

BraAke, Alex L. TER. Mining in the Netherlands Indies. Bulletin No. 4 of the Netherlands and Netherlands Indies Council of the Institute of Pacific Relations, New York, 1944.

Braddell, Sir Roland. 'A Note on Sambas and Borneo', JRASMB. September 1949, pp. 1-12.

Broek, JAN O. M. Economic Development of the Netherlands Indies Honolulu, Institute of Pacific Relations, 1942. 
Broersma, R. Handel en bedrijf in Zuid-en Oost-Borneo. 's-Gravenhage, Naeff, 1927.

Brooke, Sylvia (Ranee of Sarawak). The Three White Rajas. London, Cassell, 1939.

Buckley, Charles Burton. An Anecdotal History of Old Times in Singapore. Singapore, Fraser \& Neave, 1902. 2 vols.

Callaghan, J. M. American Relations in the Pacific and the Far East (1784-1900). Baltimore, Johns Hopkins Press, 1901.

Capellen, T. baron van. 'Notice historique du royaume de Bandjermasin (Bornéo)', Moniteur des Indes, 1846, pp. 164-9.

CARTON DE WiART, EDMOND. Les grandes compagnies coloniales anglaises $d u X I X^{\mathbf{e}}$ siècle. Paris, Perrin, 1899.

Cator, W. J. The Economic Position of the Chinese in the Netherlands Indies. Oxford, Blackwell, 1936. (Academic dissertation, University of Leiden, 1936.)

Cheeseman, E. E. Report on Potentialities for the Cultivation of Cocoa in Malaya, Sarawak and North Borneo. London, H.M.S.O., 1948.

'Chinese in Borneo, The', The China Review, Vol. vii, 1878-9, p.1-11.

Colenbrander, H. T. Koloniale geschiedenis. 's-Gravenhage, Nijhoff, $1925-6.3 \mathrm{dln}$.

Colijn, H. (ED.). Neerlands Indië: land en volk; geschiedenis en bestuur; bedrijf en samenleving. Amsterdam, Elsevier, 1911. 2 dln.

— Politiek beleid en bestuurszorg in de buitenbezittingen. Batavia, Landsdrukkerij, 1907-14. 3 dln.

Collet, Octave-J-A. L'île de Java sous la domination française. Bruxelles, Falck, 1910.

Cook, J. A. Bethune. Sir Thomas Stamford Raffles. London, Stockwell, 1918.

Costin, W. C. Great Britain and China (1833-1860). Oxford, Clarendon Press, 1937.

Coupland, Sir Reginald. Raffles of Singapore. London, Collins, 1946.

Crawfurd, John. A Descriptive Dictionary of the Indian Islands \& Adjacent Countries. London, Bradbury \& Evans, 1856.

- History of the Indian Archipelago. Edinburgh, Constable, 1820. 3 vols.

Dijk, L. C. D. vaN. Neêrland's vroegste betrekkingen met Borneo, den Solo-archipel, Cambodja, Siam, en Cochin-China. Amsterdam, Scheltema, 1862.

Doren, J. B. J. van. Bijdragen tot de kennis van verschillende overzeesche landen, volken, enz. Amsterdam, Sybrandi, 1860-4. 2 dln.

- De terugkomst der Nederlanders en de uitbreiding van hun gezag op het eiland Borneo. Amsterdam, Sybrandi, 1865.

Egerton, Hugh E. A Short History of British Colonial Policy 1606-1909. (12th Ed.). London, Methuen, 1950.

- Sir Stamford Raffles: England in the Far East. London, Unwin. 1900. 
EISENBerger J. Kroniek der Zuider-en Oosterafdeeling van Borneo Bandjermasin, Liem Hwat Sing, 1936.

Encyclopaedie van Nederlandsch-Indië. 's-Gravenhage, Nijhoff, 19171939. $8 \mathrm{dln}$.

Enthoven, J. J. K. Bijdragen tot de geographie van Borneo's Westerafdeeling. Leiden, Brill, 1903. 2 dln.

Facts about Sarawak, The. London, Balding \& Mansell, 1946.

'Financiëele resultaten van het bestuur der Buitenbezittingen van 1839 tot 1862, De', De Indische Gids, 1890, ii, pp. 1336-9.

Foster, Sir William. England's Quest of Eastern Trade. London, Black, 1933.

Gibson-Hill, C. A. 'John Clunies Ross and Alexander Hare, Merchant', JRASMB, 1952, Pts. 4 and 5.

GijsberTs, A. H. 'De tegenwoordige politieke en economische toestand van de Westkust van Borneo', Verslagen der algemeene vergaderingen van het Indisch Genootschap, 1891, pp. 175-202.

GoNGGRIJP, G. Schets ener economische geschiedenis van NederlandsIndië. Haarlem, Bohn, 1949.

Gosse, Philip. The History of Piracy. London, Longmans, 1932.

GreenBerg, Michael. British Trade and the Opening of China 1800-42. Cambridge, University Press, 1951.

Groeneveldt, W. P. 'Notes on the Malay Archipelago and Malacca', in Miscellaneous Papers relating to Indo-China and the Indian Archipelago, Second Series, Vol. i. London, Trübner, 1887.

GRoot, C. DE. Eene bijdrage tot de kennis van de Nederlandsch Indische steenkolen. Rotterdam, Kramers, 1865.

Groot, J. J. M. DE. Het kongsiwezen van Borneo: eene verhandeling over den grondslag en den aard der Chineesche politieke vereeniging in de koloniën, met eene Chineesche geschiedenis van de kongsi Lanfong. 's-Gravenhage, Nijhoff, 1885.

Groot van Kraaijenburg, Jhr. J. P. Cornets de. 'Historical Notices upon the Piracies committed in the East Indies, and upon the Measures taken for suppressing them, by the Government of the Netherlands, within the last 30 years', in P.P., 1851, LVI, Pt. i, pp. 63-122. (Taken from a series of articles in the Moniteur des Indes, 1846/7, i, pp. 158-63, 194-204, 230-41, 267-76, $319-30$, and $1847 / 8$, i, pp. 11-21, 33-45.)

HAAN, F. DE. 'Personalia der periode van het Engelsch bestuur over Java 1811-1816', BTLV, D1. 92 (1935), pp. 477-699.

Hageman, H. J. 'Aanteekeningen omtrent een gedeelte der oostkust van Borneo', TTLV, 1855, pp. 71-106.

- 'Geschiedkundige aanteekeningen omtrent zuidelijk Borneo', TvNI, 1861, i, pp. 199-233.

Hahn, Emily. James Brooke of Sarawak. London, Barker, 1953. Raffles of Singapore. London, Aldor, 1948.

Harlow, Vincent T. The Founding of the Second British Empire. 1763-1793, Vol. i. London, Longmans, Green, 1952. 
Harrisson, Tom. 'Robert Burns - the First Ethnologist and Explorer of Interior Sarawak', The Sarawak Museum Journal, November 1951, pp. 463-77.

Hatton, Joseph. The Nerw Ceylon. London, Chapman \& Hall, 1881.

HoEk, I. H. J. Het herstel van het Nederlandsch gezag over Java en onderhoorigheden in de jaren 1816 tot 1819. 's-Gravenhage, van Cleef, 1862. (Academisch proefschrift.)

Hogendorp, Comte C. S. W. DE. Coup d'cil sur l'île de Java et les autres possessions néerlandaises. Bruxelles, de Nat, 1830.

Hughes, John Scott. Kings of the Cocos. London, Methuen, 1950.

Hughes-Hallett, H.R. 'A Sketch of the History of Brunei', JRASMB, August 1940, pp. 23-42.

Hunt, J. 'Sketch of Borneo, or Pulo Kalamantan', in Malayan Miscellanies, Vol. i, No. 8. Bencoolen, Sumatran Mission Press, 1820.

Jacob, Gertrude L. The Raja of Sarazeak. London, Macmillan, 1876. 2 vols.

KAN, C. M. Histoire des découvertes dans l'archipel indien. Leiden, Brill, 1883.

Kater, C. 'Aanteekeningen op Prof. Veth's "Westerafdeeling van Borneo", 5de boek van het tweede deel', De Indische Gids, 1883, i, pp. 12-14.

— 'Tets over de Batang Loepar Dajakhs in de "Westerafdeeling van Borneo",' De Indische Gids, 1883, i, pp. 1-11.

Keith, Sir Arthur Berriedale. The Constitution, Administration and Lares of the Empire. London, Collins, 1924.

KEMP, P. H. VAN DER. 'Het afbreken van onze betrekkingen met Bandjermasin onder Daendels en de herstelling van het Nederlandsch gezag aldaar op den $1^{\mathrm{a}}$ Januari $1817,3 T L V, 1898$, pp. $1-168$.

— 'De commissiën van den schout-bij-nacht C. J. Wolterbeek naar Malakka en Riouw in Juli-December 1818 en Februari-April $1820^{\prime}, B T L V, 1900$, pp. 1-101.

'De geschiedenis van het Londensch tractaat van 17 Maart 1824', $B T L V, 1904$, pp. 1-244.

- Het Nederlandsch-Indisch bestuur in 1817, tot het vertrek der Engelschen. 's-Gravenhage, Nijhoff, 1913.

— Oost-Indië's herstel in 1816. 's-Gravenhage, Nijhoff, 1911.

- 'De sluiting van het Londensch tractaat van 13 Augustus 1814', BTLV, 1897 , pp. 239-339.

- 'De stichting van Singapore, de afstand ervan met Malakka door Nederland, en de Britsche aanspraken op den Lingga-Riouwarchipel', $B T L V, 1902$, pp. 313-476.

- De teruggave der Oost-Indische koloniën 1814-1816. 's-Gravenhage, Nijhoff, 1910.

- 'De vestiging van het Nederlandsch gezag op Borneo's Westerafdeeling in 1818-1819. Naar onuitgegeven stukken', BTLV, 1920, pp. $117-61$.

Kennedy, RAYMond. The Ageless Indies. New York, Day, 1942. 
Kessel, O. van. 'Statistieke aanteekeningen omtrent het stroomgebied der rivier Kapoeas ...', Indisch Archief, 1850, pp. 165-200.

Kielstra, E. B. 'Bijdragen tot de geschiedenis van Borneo's Westerafdeeling', De Indische Gids, 1889-90, 1893-4, passim.

- Indisch Nederland. Haarlem, Bohn, 1910.

- De Indische archipel. Haarlem, Bohn, 1917.

'Noord-Borneo', Onze Eeuw, 1914, pp. 334-61.

- 'De ondergang van het Bandjermasinsche rijk', De Indische Gids, 1890 , ii, pp. $2389-2418$; 1891 , i, pp. $12-39,364-87,819-45$; 1891, ii, pp. $1360-86,1709-31,2191-2211 ; 1892$, i, pp. $11-43$, 205-17.

- De vestiging van het Nederlandsch gezag in den Indischen archipel. Haarlem, Bohn, 1920.

'West-Borneo', Onze Eeuw, 1916, pp. 239-56.

KLERCK, E. S. DE. History of the Netherlands Indies. Rotterdam, Brusse, 1938. 2 vols.

Knaplund, Paul. Gladstone and Britain's Imperial Policy. London, Allen \& Unwin, 1927.

KNIPHORST, J. H. P. E. 'Historische schets van den zeeroof in den Oost-Indischen archipel' (II ${ }^{\mathrm{e}}$ hoofdstuk, deel iv), Tijdschrift voor het Zeewezen, 1880 , ii, pp. 89-204.

KnAppert, S. C. 'Beschrijving van de onderafdeeling Koetei', BTLV, 1905, pp. $575-654$.

LevysSOHN NoRman, H. D. De britsche heerschappij over Java en onderhoorigheden (1811-1816). 's-Gravenhage, Belinfante, 1857. (Academisch proefschrift.)

Leyden, John. 'Sketch of Borneo', Moor's Notices, Appendix.

Logan, J. R. 'Borneo: Notices of European intercourse with Borneo Proper prior to the establishment of Singapore in 1819', Journ. Ind. Arch., 1848, pp. 495-527.

- 'Notices of Chinese Intercourse with Borneo Proper prior to the establishment of Singapore in 1819', ibid., pp. 611-15.

- 'The piracy and slave trade of the Indian Archipelago', Journ. Ind. Arch., 1849, pp. 581-8, 629-36; 1850, pp.45-52, $144-62$, $400-10,617-28,734-46 ; 1851$, pp. $374-82$.

- Traces of the Origin of the Malay Kingdom of Borneo Proper, with Notices of its Condition when first discovered by Europeans and at later periods', Journ. Ind. Arch., 1848, pp. 513-28.

Low, Sir Hugh. British North Borneo. London, Kegan Paul, 1899.

- 'Selesilah (Book of the Descent) of the Rajas of Bruni', JRASSB, June 1880 , pp. $1-35$.

Meeteren Brouwer, P. M. van. 'De geschiedenis der Chineesche districten der Wester-afdeeling van Borneo van 1740-1926', De Indische Gids, 1927, ii, pp. 1057-1100.

Meyners, H. G. J. L. Bijdragen tot de kennis der geschiedenis van het Bandjermasinsche rijk 1863-1865. Leiden, Brill, 1886.

Mills, Lennox A. 'British Malaya 1824-1867', JRASMB, November 1925. 
Morley, John. The Life of Richard Cobden. London, Unwin, 1898. 2 vols.

Morrell, W. P. British Colonial Policy in the Age of Peel and Russell. Oxford, Clarendon Press, 1930.

NAGTEGaAL, C. De voormalige zelfbesturende en gouvernementslandschappen in Zuid-Oost Borneo. Utrecht, Oosthoek, 1939.

Netscher, E. 'Kronijk van Sambas en Soekadana; in het oorspronkelijk Maleisch, voorzien van de vertaling en aanteekeningen', $T T L V$, 1853 , pp. $1-41$.

Nilakanta Sastri, K. A. 'A note on the Sambas finds', JRASMB, September 1949, pp. 16-22.

Noorlander, J. C. Bandjermasin en de Compagnie in de tweede helft der $18^{\circ}$ eeuw. Leiden, 1936. (Academisch proefschrift.)

Nusselein, A. H. F. J. 'Beschrijving van het landschap Pasir', $B T L V$, 1905, pp. 532-74.

Ong Eng DiE. Chineezen in Nederlandsch-Indië. Assen, van Gorcum, 1943.

OzIngA, JАСов. De economische ontwikkeling der Westerafdeeling van Borneo en de bevolkingsrubbercultuur. Wageningen, Zomer \& Keuning, 1940. (Academisch proefschrift.)

Parkinson, C. Northcote. Trade in the Eastern Seas (1793-1813). Cambridge, University Press, 1937.

Pety de Thozée, Ch. et R. Théories de la colonisation au XIX $X^{\bullet}$ siècle, et rôle de l'état dans le développement des colonies. Bruxelles, Hayez, 1902.

Posewitz, Theodor. Borneo: its Geology and Mineral Resources. London, Stanford, 1892.

Purcell, Victor. The Chinese in Southeast Asia. London, Oxford University Press, 1951.

Raffles, Sophia (Lady). Memoir of the Life and Public Services of Sir Thomas Stamford Raffles, F.R.S., etc.... London, Murray, 1830.

ReEs, W. A. van. De Bandjermasinsche krijg van 1859-1863. Arnhem, Thieme, 1865. $2 \mathrm{dln}$.

- De Bandjermasinsche krijg nader toegelicht. Arnhem, Thieme, 1867.

- Montrado. Geschied- en krijgskundige bijdrage betreffende de onderwerping der Chinezen op Borneo. 's-Hertogenbosch, Muller, 1858.

- Wachia, Taykong en Amir, of het Nederlandsch-Indisch leger in 1850. Rotterdam, Nijgh, 1859.

Rengers, D. W. van Welderen. The Failure of a Liberal Colonial Policy: Netherlands East Indies, 1816-1830. The Hague, Nijhoff, 1947.

Rutter, E. Owen. British North Borneo. London, Constable, 1922. The Pirate Wind. London, Hutchinson, 1930.

St. John, Horace. The Malay Archipelago: its History and Present State. London, Unwin, 1853. 
St. John, Sir Spencer. The Life of Sir James Brooke, Rajah of Sarazeak. Edinburgh, Blackwood, 1879.

- Rajah Brooke: an Englishman as Ruler of an Eastern State. London, Unwin, 1899.

Saleeby, Najeeb M. The History of Sulu. Manila, Bureau of Printing, 1908.

SchaAnk, S. H. 'De kongsi's van Montrado', TTLV, 1893, pp. 498-612.

Schlegel, Gustav. 'L'organisation des Kongsi à Bornéo', Revue Coloniale Internationale, 1885 , Tome i, pp. 448-65.

Senior, William. Naval History in the Law Courts. London, Longmans, 1927.

SmULDERS, C. M. Geschiedenis en verklaring van het tractaat van 17 Maart 1824, te Londen gesloten tusschen Nederland en GrootBrittannië. Utrecht, Siddré, 1856. (Academisch proefschrift.)

Stapel. F. W. (ED.). De geschiedenis van Nederlandsch-Indië. Amsterdam, van den Vondel, 1938-40. 5 dln.

StURLER, JACQUES ÉDUARD DE. Het grondgebied van Nederlandsch Oost-Indië in verband met de tractaten met Spanje, Engeland en Portugal. Leiden, Somerwil, 1881. (Academisch proefschrift.)

Temminck, C. J. Coup-d'œil général sur les possessions néerlandaises dans l'Inde archipélagique. Leide, Arnz, 1846-9. 3 vols.

Thomas, W. Cave. Murray's Expedition to Borneo: an Episode in the Early Life of Edwin Robin Thomas. London, Lawrence \& Bullen, 1893.

Treacher, W. H. 'British Borneo: Sketches of Brunai, Sarawak, Labuan and North Borneo', JRASSB, 1889, pp. 13-74; 1890, pp. 19-122.

'Verwikkelingen van het Nederlandsch-Indisch Gouvernement met de Chinesche bevolking op westelijk Borneo toegelicht, De', TvNI, 1853, ii, pp. 273-410.

VETH, P. J. Borneo's Westerafdeeling, geographisch, statistisch, historisch, voorafgegaan door eene algemeene schets des ganschen eilands. Zaltbommel, Noman, $1854-6.2$ dln.

VlekKe, Bernard H. M. Nusantara: a History of the East Indian Archipelago. Cambridge, Mass., Harvard University Press, 1943.

WaAL, E. DE. Onze Indische financiën. 's-Gravenhage, Nijhoff, 18761907. $10 \mathrm{dln}$.

Webster, Sir Charles K. The Foreign Policy of Castlereagh, 18121822. London, Bell, 1925-31. 2 vols.

Wijck, Herman van Der. De Nederlandsche Oost-Indische bezittingen onder het bestuur van den Kommissaris-Generaal du Bus de Gisignies (1826-1830). 's-Gravenhage, Nijhoff, 1866. (Academisch proefschrift.)

Willi of Gais, Johannes. The Early Relations of England with Borneo to 1805. Langensalza, Beyer, 1922. (Doctoral dissertation, University of Berne.)

Winstedr, Sir RICHARD. 'A History of Malaya', JRASMB, March 1935. 
Woodward, E. L. The Age of Reform, 1815-1870. Oxford, Clarendon Press, 1949.

Young, J. W. 'Bijdrage tot de geschiedenis van Borneo's Westerafdeeling', $T T L V, 1895$, pp. 499-550.

\section{MEMOIRS, TRAVELLERS' ACCOUNTS, AND REMINISCENCES}

AdRIANI, P. Herinneringen uit en aan de Chineesche districten der. Wester-afdeeling van Borneo, 1879-1882. Amsterdam, Campagne, n.d.

Brooke, Sir Charles. Ten Years in Sarazak. London, Tinsley, 1866. 2 vols.

Brooke, Ranee Margaret. My Life in Sarawak. London, Methuen, 1913.

Burbidge, F. W. The Gardens of the Sun. London, Murray, 1880.

Burns, Robert. 'The Kayans of the North-West of Borneo', Journ. Ind. Arch., 1849, pp. 138-52.

Doty, E. and Pohlman, W. J. 'Tour in Borneo, from Sambas through Montrado to Pontianak... during the autumn of 1838', The Chinese Repository, Vol. viii, pp. 283-310.

'E. F. S.' 'My Friends in Labuan', Macmillan's Magazine, 1906-7, pp. $39-43$.

Francis, E. Herinneringen uit den levensloop van een' Indisch' ambtenaar van 1815 tot 1851. Batavia, van Dorp, 1856-60. 3 dln.

Hamilton, Captain Alexander. 'A New Account of the East Indies', in John Pinkerton, A General Collection of the Best and Most Interesting Voyages and Travels..., Vol. viii, pp. 258-522. London, Longmans, 1811.

Helms, Ludvig Verner. Pioneering in the Far East. London, Allen, 1882.

Lay, G. Tradescant. Notes made during the Voyage of the Himmaleh in the Malayan Archipelago. New York, French, 1839.

Marryat, Frank S. Borneo and the Indian Archipelago. London, Longmans, 1848.

'Notices of the city of Borneo and its inhabitants, made during the voyage of the American brig Himmaleh in the Indian Archipelago, in 1837', The Chinese Repository, Vol. vii, pp. 121-36, 177-93.

Pigafetta, Anthony. 'Account of Magellan's Voyage', in The First Voyage Round the World (ed. Lord Stanley of Alderney). London, Hakluyt Society, 1874.

Pryer, Ada. A Decade in Borneo. London, Hutchinson, 1894.

Ross, John Dill. Sixty Years: Life and Adventure in the Far East. London, Hutchinson, 1911. 2 vols. 
St. John, Sir Spenser. Adventures of a Naval Officer. London, Digby, Long, 1905. (Published under the pseudonym of 'Captain Charles Hunter, R.N.'.)

Life in the Forests of the Far East. London, Smith, Elder, 1863. 2 vols.

Wilkes, Admiral Charles. Narrative of the United States Exploring Expedition (1838-1842). London, Putnam, 1845. 6 vols. 


\section{APPENDIX ' $C$ '}

\section{N D E X}

A

Abdul Mumin, Sultan, 212

Abdu'r-Rahman, Sultan, 6

Aberdeen, George Hamilton-Gordon, Earl of (1784-1860), 86-7, 89, 97, 100, 103-8,

$110,112,113,117-19,120,124,147-8$

Aborigines Protection Society, 140, 144

Abraham, Thomas, 39, 42

Adam, Sultan, 175

Adderley, C. B. (1814-1905), 189

Admiralty, British, 79, 94-7, 110-11, 116$18,120,125,131,136,144$

Agincourt, H.M.S., 90, 114

Albatross, H.M.S., 139-40

Alcock, Sir Rutherford (1809-97), 204-5, 210

Amalgamated China Steamship and Labuan Coal Co, 177

Ambong, 85, 195

American Trading Co of Borneo, 195-6, 199

Andaman Islands, 95

Andresen, Maj., 172-4

Anna (brig), 102

Annam, 213

Antimony, 72-4, 76, 128, 130-3, 146, 147

Arabs, 73, 81, 90

Ariel (brig), 84

Army, Dutch colonial, 50, 168-73, 216

Ascension Island, 95, 97

Assahan (coal-mine), 164

Atjeh, 55, 62

Auchmuty, Lieut.-Gen. Sir Samuel, 15

Australia, 11, 96, 98

Austria, 60, 199, 201, 207

\section{B}

Badru'd-din, Pĕngeran, 113

Bakoempai, 44

Balabac Island, 195, 202

Balambangan Island, 9-10, 64, 111, 117

Balanini pirates, 111, 178

Bali, 14, 28, 62, 115

Bandjermasin, 8, 12-13, 26, 67, 81, 82,
159; Anglo-Dutch controversy over, 35-49, 55 ; British settlement at, 16-21, $26,28,29,31,33-4,35-42,44-9$; Dutch settlements at, 12-13, 38-9, 42-9, 55, 58

Bandjermasin, Sultanate of, 3, 4-7, 44, 153, 161-5, 174-6; coal-mining in, 163-5

Bandjermasin, Sultans of, 4-5, 7, 12-14, $16-21,37-8,41,42-9,51,153-4,165$, $175-6$

Bandjermasin War, 175-6, 185

Banggi Island, 195

Banka Island, 33, 62, 162-3, 170

Bannerman, Governor, 52, 55

Bantam, 4-6, 8, 170

Baram, Tanjong, 134

Baram Cession, 191-3, 209-10, 212

Barito, River, 152, 175

Basilan Island, 109

Batang Marau, Battle of, 140, 143-5

Batavia, 12, 28, 35, 39, 42, 152

Batoe-poetih, 154

Battam Island, 62, 64, 66

Bau, 183

Baud, Jean Chrétien (1789-1859),. 63, 68, 99, 101, 152-3, 155, 160, 165

Belcher, Capt. Sir Edward (1799-1877), $79,84-6,92-3,94,96,112,120,146$, 154-5

Belgium, 109, 187

Bencoolen, 16, 47, 49

Bengal, 40, 41, 96

Berbice, 32, 33

Berouw, 44, 153

Bethune, Capt. Drinkwater, 89, 90, 94, 96-7, 110-11, 116-17

Billiton Island, 62

Bintang Island, 62, 64, 66

Bintulu, River, 130-3, 147, 191

Bismarck, Otto E. L. Vorst von (181598), 213

Blockade: of Borneo by Raffles, 26-7, 31 ; of Holland by British, 6; of Java by British, 12; of Sulu by Spain, 197-8; of Western Borneo by Dutch, 168, 171 
Bloem, R., 69-70, 74, 99-101

Bloem, W., 32

Board of Commissioners in Java, British, 35-9, 46

Boekholtz, Jacob d'Arnaud van, 42-4, 46-7, 50-3, 59

Boeloengan, 153-5, 197

Bone, Raja of, 99

Bonham, Sir Samuel George (1803-63), 72, 91

Borneo Company, Ltd., 183, 185, 208

Bosch, Johannes graaf van den (17801844), 68, 152, 155

Bowen, Capt. J., 24-5

Bright, John (1811-89), 144

Bron de Vexela, Lt.-Col. le, 168, 172

Brooke, Sir Charles Johnson (1829-1917), 190-4, 204, 207-10, 212-14

Brooke, Sir James (1803-68): his early life, 70-2; his acquisition of Sarawak, $72-7,101,127,128,151,176,215,217$; his attitude to commerce, 71-2, 78, 127$38,146-50,162$; his personal finances, $77,124,127,129-30,135,146,184-6$; his pirate policy, $77,80-6,89-92,94$, $112-13,114,126,129,139-50$; his quest for foreign protection, 183, 185-6; his relations with the British Government, 77-9, 87-94, 97, 100, 103-5, 109-11, 118, 120-2, 124-6, 181-90; with Brunei, 72, 84, $86-7,112-15,124-6,147-50,194$; with the Dutch, 70, 72, 88, 98-105, 107, 155, 157-8, 207; with Henry Wise, 79-80, $86-9,96,104,111,113,126-9,133,143$, 146, 217; his rule in Sarawak, 124, 126, $129-30,133,146,150-1,161,176,215$, 217 ; as a servant of the British Crown, $124-6,131,133,136-8,144,146-50$

Brooke, Capt. John Brooke, 186

Brunei, 2, 4, 26-7, 76, 84-5, 89-93, 103 , $114-15,122,177,195,199,209$; trade of, 179, 209

Brunei, Massacre of (1846), 112-14, 116, 118, 125

Brunei, Sultanate of, 3, 4, 22, 23, 54, 74, 82, 131, 138, 153; American relations with, 110; British relations with, 84, $86,88,94,110,112-14,122-6,191-5$, 217; Dutch relations with, 69-70, 101, 104, 107; relations of Sarawak with, 181-90, 191-5; coal-mining in, 79-80, $84,96,97,110,133-8,163,177$
Brunei, Sultans of, 27-8, 31, 69-77, 84, $86,88-90,92-4,110-15,122-6,131-3$, $135,139,147,181,191-5,200,207-10$; territorial concessions by, $84,86,89$, $92-4,125,147-50,160,195,199-201$, 203-5, 207-8, 212-15

Brunei, Těmĕnggong of, 195, 200

Brunei Bay, 88, 112, 124

Brunei River, 114, 123

Bugis, Buginese, 3, 6, 20, 99, 104

Bulwer-Lytton, Sir Edward (1803-73), 184, 187

Burdett-Coutts, Angela, Baroness (18141906), 185

Burn, F., 23

Burns, Robert, 131-3

Bus de Gisignies, L. P. J. comte du (1780-1849), 67-8

Butterworth, Governor, 85, 92

Buyskes, Rear-Adm. A.A. (1771-1838), 35

Bylandt, C. M. E. G. graaf van (181893), 204, 207

\section{$\mathrm{C}$}

Cagayan Sulu, 202

Calcutta, 9, 28, 29, 30, 56, 71

Cambodia, 28

Canning, George (1770-1827), 58-61, 64-5, 106, 108

Canton, 8-9, 95, 109, 183

Cape of Good Hope, 32, 33, 49, 95

Capellen, G. A. G. P. baron van der (1778-1848), 35, 59, 67

Capellen, Lieut. J. van, 154

Carimon Islands, 62, 64, 66

Carnarvon, Henry Herbert, Earl of (1831-90), 179-80

Caroline Islands, 213

Castlereagh, Robert Stewart, Viscount (1769-1822), 33, 49, 56-7

Celebes, 11, 62, 71, 75, 99, 104

Ceylon, 32, 95

Chagos Islands, 95

Chambers of Commerce, British, 78-9, $116,118,121$

Chamerovzow, Louis A., 240

Charter, British North Borneo Company, 204-5, 210-12, 217

Chêng Hung, 170-1, 173, 174

Cheribon, 41

China, 2, 3, 7, 71, 109, 114, 115, 122, 139 , 168; American trade with, 56; British trade with, $8-11,51,57,65,80,87,95$, $98,115,120,180,213$ 
Chinese: in Dutch Borneo, 7, 22, 24, 25 , 51, 100,141, 161, 166-74, 176, 201, 216; in Labuan, 178, 209; in Sarawak, 73, $100,166,170,183$

Chinese Insurrection (1857), 183, 185

Christian missions, 155-6

Church, Thomas, 79

Churmin, Pulau, 80

Clancarty, Richard Trench, Viscount (1767-1837), 56, 58

Clarendon, George Villiers, Earl of (180070), 147-8, 183-4, 188

Clunies-Ross, John (1786-1854), 46-9

Coal-mining : in Brunei, 79-80, 84, 96, 97, $110,133-8,163,177$; in Dutch Borneo, 163-5; in Labuan, 96, 97, 134-8, 163, $177-8,180$

Cobden, Richard (1804-65), 144

Cochin China, 28, 109

Cochrane, Rear-Adm. Sir Thomas (17891872), 90-1, 94, 103, 113-14, 122, 126, 129

Cocos Islands, 49

Collier, Rear-Adm. Sir Francis, 139

Colonial Department, Dutch, 46, 61

Colonial Office, British, 61 ; and the British North Borneo Co, 209-10, 21314; and coal-mining in Borneo, 135-7; and Labuan, 178, 179-80, 196; and plans for a Crown Colony in Borneo, 87-9, 94, 97, 105, 111-12, 115-21

Colonies, Dutch Ministry of the, 101, 105, 158

Commerce (merchantman), 23, 73

Commission of Inquiry, Singapore (1854), $147-50,181$

Commissioners for Bandjermasin, British, $39-42,44$

Commissioners-General, Dutch, 35-49, 50-1

Congalton, Capt., 80

Conservative Party, Dutch, 207; British, 210

Constitution, U.S.S., 110

'Constitutional Revision' (1848), 159

Consular representation in Sarawak, 182-3, 188-9

Contracts, see Treaties

Convention of $1814,33,35,36-9,43,48$, $51,53,60-1$

Convicts, 20-1, 40-2, 178, 180, 196

Cowie, William C., 198-9

Cracroft, W. S., 52

Crawfurd, John (1783-1868), 96-7, 120-1
Crookshank, A. C., 131-2

Culture System, 68, 151, 160-1

Customs duties, 17, 69, 155

\section{D}

Daehne \& Co, 161-2

Daendels, Marshal H. W. (1762-1818), $12,15,36,37-8,55$

Dalrymple, Alexander, 9-10

Datu, Tanjong, 75, 182, 191

Dedel, Salomon baron (1775-1846), 99, 103-8, 207

Demak, 3

Demarara, 32, 33

Demarcation line, Anglo-Dutch, 30, 53-5, $59,63-7,105-8$

Dent, Sir Alfred, 199-201, 204-5, 208, 211, 217

Dent \& Co, 199

Dent-Overbeck concessions, 200-1, 203-5, 207-8, 214-15

Derby, Edward Stanley, 14th Earl of (1799-1869), 78, 97, 111, 112, 120, 147, 184, $187-8$

Derby, Edward Stanley, 15th Earl of (1826-93), 193

Devereux, H. B., 149-50

Dewall, $H$. von, 156-7

Diamonds, 7, 14, 17, 21, 44, 128

Diama, H.E.I.C.S., 76, 80, 91

Dido, H.M.S., 80-6, 93, 139

Direct rule, 161, 165, 173, 174-6

Djailolo Passage, 65

Djelai, 44

Driver, H.M.S., 90

Dungen Gronovius, D. J. van den, 69

Dyaks, 2, 22, 51, 126, 141, 157, 161, 169, 171 ; in Sarawak, 73-4, 157, 162, 183; as auxiliary forces, $83,85,139-40,142$, 149 ; as pirates, 81-6, 92, 94, 139-50, 217

\section{E}

East Coast of Borneo, 2, 17, 44, 54, 102-3, $105,153-5,157,159,163-5,174-6,200$

East India Associations, British, 78-9, 116,121

East India Company, Dutch, 5-7, 22, 215

East India Company, English, 7-10, 29-30, $35,58,61,64,91,95,111,178$; and Java, 15, 29-30, 32, 51, 65; and policy in Borneo, 16, 29-34, 35-6, 42, 51-67, 72, 119-21, 217 
East India House, 33, 59

Eastern Archipelago Co, 135-8, 149, 177

'Eastern Passage', 11, 65

Eerens, Dominique J. de (1781-1840), 68, 99

Egerton, Commander, 112-13

Ellenborough, Edward Law, Earl of (1790-1871), 111, 144, 145

Elliot, T. F., 179

Elout, Cornelis Th. (1767-1841), 35, 46-7, $58-9,64,66,67$

Essequibo, 32, 33

Essington, Port, 116

F.

Fagel, Hendrik baron (1765-1838), 57, 58, 60, 61, 63, 66

Falck, Anton Reinhard (1777-1843), 48, $57-8,60,61,63,64-7,108$

Falkland Islands, 121

Farquhar, Commander, 139-43, 145

Farquhar, Maj. John, 52-3, 59

Fendall, John, 35-9, 41-3, 48

Ferry, Jules F. C. (1832-93), 213

Flag of Sarawak, 181

Flores, 62

Foggo, George, 141

Foreign Affairs, Netherlands Ministry of, 99, 102-8, 160, 204-6

Foreign Office, British : and Borneo, 86-7, $91,94,97,103-8,115-26,136-7,144$, $160,180-1,204-7,217$; and the British North Borneo Co, 204-7, 210-14; and Brunei, 84, 86, 88, 94, 110, 112-14, 122-6, 191-5, 217; and the Netherlands, 60,99 , $102-8,117-19,160,204-6$; and Sarawak, $86-9,91,94,121-2,137,147-50,181-90$, 192-4, 207-10, 212-14; and Sulu, 197-8

France, 29, 55, 56, 60, 109, 119, 152, 213, 217

Friendship (merchantman), 109

Frontiers, 125, 157, 182, 191, 202-3, 206

\section{G}

Gallois, J. G. A., 157

Gardner, James, 77, 79

Garnham, Capt. Robert C., 27-9

Gaya Bay, 196, 200

Germany, 197-8, 210, 213, 217

Gladstone, William Ewart (1809-1898), $111-12,117-21,144,147,210$

Glasgow, 115, 116, 121, 187
Gliddon \& Co, 130, 147

Gloucester Lodge discussions (1823-4), 60-1, 64-5

Gold, 7, 14, 17, 21 ; gold-mining, 22, 44, $166,168-9,173,183$

Goldberg, Jhr. Johannes (1763-1828), 44

Goltstein, Willem baron van (1831-1901), 203

'Government of Borneo', 156-9

Granville, George Leveson-Gower, Earl (1815-91), 204, 210-11

Great Britain, Government of: policy towards Borneo, 7-11, 86, 89, 94, 110$12,113,116-26,128,134,136-7,144$, 160, 180-1, 204-7, 217; see also Colonial Office and Foreign Office

Grey, Henry George Grey, Earl (180294), 119, 121, 125, 136

Grisek, 41

Gunpowder, 42, 49, 70, 85, 99, 101, 104, 166-7

$\mathrm{H}$

Haddington, Thomas Hamilton, Earl of (1780-1858), 79, 89, 111, 128

Halmahera, 11, 62, 145-6

Hamilton, Acting-Governor, 180

Hamilton, Alexander, 8

Hamilton, Gray \& $\mathrm{Co}, 131-2$

Harbours of refuge, 95, 96, 109, 217

Hare, Alexander, 13, 16-21, 29, 35-41, 46-9

Hare, John, 40

Harlequin, H.M.S., 84

Hartmann, C. L., 50, 68

Hassim, Raja Muda of Brunei, 73, 74-7, $82-3,85-6,89,90,92,110,112-13,125$

Hassim, Těměnggong of Brunei, 212-13

Hastings, Francis Rawdon-Hastings, Marquis of (1754-1826), 29-31, 34, 48, 53-7, 59

Hawes, Benjamin (1797-1862), 119, 121

Hazard, H.M.S., 112-14

Head-hunting, 1, 2, 51, 81-2.

Head-money, 144-6

Heath, Lieut., 123, 134

Henderson \& $\mathrm{Co}, \mathrm{R}$. and J., 134

Herbert, Sidney (1810-61), 144, 146, 147

Hicks-Beach, Sir Michael (1837-1916), 209

Hidayat Ullah, 175-6

Himmaleh (brig), 80, 110

Ho Shun, 173 
Hoëvell, W. R. baron van (1812-79), 160-1

Hong Kong, 11, 84, 87, 95, 96, 121, 122 , 178,195 ; its trade with Borneo, 102, 198-9

Hoop (coal-mine), 164

Hora Siccama, O. W., 64

Hume, Joseph (1777-1855), 140-4, 146

Hunt, John, 1-2, 26

\section{I}

India, $2,8,10,11,28,33,55,64,95,127$, 128

India, British Government of, 27, 29-31, $47,48,51,57,85$

India Board, 48

Indian Mutiny, 185

Inglefield, Rear-Adm., 134

Iris (Dutch warship), 43

Iris, H.M.S., 114-15, 122-4

Iron, iron-mining, 110, 161-3

Italy, 196

\section{J}

Jackson, President Andrew (1767-1845), 109

Janssens, Gen. Jan W. (1762-1838), 15, 38

Japan, 56, 109

Japar, 112-13

Java, 2, 3, 6, 8, 12, 46, 54, 151, 155, 163, 164,215 ; British rule in, 12-16, 17, 18, $27-8,29,34,35-9,46,52$; restoration of Dutch rule to, 35,55

Java War, 67

Johore, 3, 64, 66, 67

Jolo, 198

Julia Hermina (coal-mine), 164, 176

\section{$\mathrm{K}$}

Kanowit, Fort, 185

Kapoeas, River, 156-7

Kayan, 131

Kedah, 63

Keppel, Capt. the Hon. (later Admiral of the Fleet Sir) Henry (1809-1904), 80-6, $92-4,125,126,129,137,139-40,142$, 204, 210

Kervel, T. A. C. van, 167

Kianggi, 80

Kidurong, Cape, 191

Kimanis Bay, 115, 195, 200
Kimberley, John Wodehouse, Earl of (1826-1902), 210

Kinabatangan, River, 3

Koeran, River, 153

Koetei, 2, 44, 54, 102-3, 105, 153, 154, 157, 164

Kongsis, Chinese gold-mining, 22, 166-74, 183

Koninklijke Academie, 215

Kota Waringin, 5, 44

Kuala Batu, 109

Kuching, 73-6, 81-5, 89, 113-14, 120, 126, $131-2,139,146,179,183-4,188-9,191$, 209

Kween, 44

\section{L}

Labour force, 19-21, 41, 177-8

Labuan, 115, 132, 177-81, 189, 195, 196; cession of, $86,88,90,94,97,107,111$, $116,123-4$; coal-mining in, $96,97,134-8$, $163,177-8,180$; foundation of British colony at, 115-26, 139, 217

Labuan, Government of, 136-9, 180-1, 187, 192-3, 196, 207, 209, 212

Labuan Coal Co, 177

Labuan Trading Co, 198-9

Laccadive Islands, 95

Lan Fang (kongsi), 166, 170

Land tenure in Brunei, 200

Landak, 3, 5, 6, 67, 68

Lanun pirates, 23, 25, 90-1, 92, 111, 114, 178

Larah, 22, 166

Lawai, 44

Lay, G. Tradescant, 80

Liberal Party, British, 210-11; Dutch, 160-1, 207

Limbang Revolt, 212

Lingga Archipelago, 28, 52, 53, 62, 66, 152

Lingga, River, 85

Liverpool, 116, 187

Logan, J. R., 130

Lombok, 14, 62

Lompullë', Datu, 104

London, City of, 116, 121, 129, 134, 187, 211

London Peace Society, 140, 144

London Talks: of 1820, 57-60, 64; of 1823-4, 60-7

Lord Melbourne (merchantman), 81

Lundu, River, 69, 75

Lupar, Batang, 81, 85 
M

Macassar, 27; Straits of, 11, 65

Macdonald, Capt., 31

Madras, 9, 71

Madura, 14, 62

Maeander, H.M.S., 125, 139

Mahakam, River, 102

Maitland, Rear-Adm. Sir Frederick, 98

Majapahit, 2-3

Makota, Pěngeran, 74, 76

Malacca, 3, 4, 13, 18, 26, 52, 54, 55, 80 ; Straits of, 8, 11, 32, 51, 53, 55-7, 63, 64, $80,87,95,215$

Malacca (brig), 23

Malacca, H.M.S., 27

Malaya, 3, 52, 62, 183

Malays: in Borneo, 3, 73, 141, 161, 171, $177-8,183$; pirates, $81,94,95,217$

Maldive Islands, 95

Malmesbury, James Harris, Earl of (1807-89), 184

Mampawa, 6, 58, 67, 68; Panembahan of, 22

Manchester, 116, 118, 121, 187

Mandor, 22, 166

Marabahan, 152

Martapoera, 4, 164, 165

Martin, R. B., 204-5

Marudu, Battle of, 91, 94

Marudu Bay, 72, 75, 85, 90-1, 92, 94, 132, 195, 197, 202, 208

Massacre of Brunei (1846), 112-14

Mataram, 5, 14

Mauritius, 56, 95

Mayne, Rear-Adm. R. C., 205

Melville, Anstruther and Wise (partnership), 134-5

Melville \& Street, Co, 135

Membakut, River, 115

Mendawai, 44

Mengkabong, 134

Methven, Lieut. Cathcart, $3^{\circ}$

Miles, William Henry, 134

Miners, Chinese gold, 22, 11, 67-8, 70, 166-74, 183

Mining Service, Dutch G vernment, 163

Minto, Gilbert Elliot, Earl of (1751-1814), $14-16,18,23,29,34$

Moira, Lord, see Hastings, Marquis of

Moloeko, 38, 42, 46-9

Moluccas, 8, 12, 15, 59, 158

Montgelas, Count, 199

Montrado, 22, 166-74
Moros, 197

Morotai, 62

Moses, Charles Lee, 195, 199

Muara Island, 112, 177

Mukah, 191

Müller, George, 51, 154

Mumin, Pěngeran, 123

Mundy, Capt. G. Rodney (1805-84), 114$15,122-6$

Muntinghe, Maj., 50

Murray, Hon. Erskine, 102-3, 153-4, 155

Musahor Revolt, 185

Muskets, 49, 99, 101, 104, 141

$\mathrm{N}$

Nanking, Treaty of (1842), 87

Napier, William, 137

Napoleon III, Emperor, 185

Naval stations, 15, 95; in Borneo, 86, 89, 94, 97, 107, 110-11, 112, 116-26, 210, 217

Navy: Austrian, 199; British, 6, 103, 116, 163,211 ; in the Far East, 23, 95, 113$14,121-3,126,134$; and suppression of Bornean piracy, 80-6, 90-4, 103, 105, 114, 129, 139-50, 177-9; Dutch, 12, 23, $154,163,167-8,178,202,206$; Italian, 196; Spanish, 202

Nemesis, H.E.I.C.S., 139-40

Netherlands, Government of the, 32, 60 , 159-60; and Borneo, 10-11, 35, 98-108, 160, 202-7, 210, 215-17; and the British North Borneo Co, 202-7; and Great Britain, 52-67, 98-108, 117-18, 119, 160, 204-6

Netherlands Indian Government: and Borneo, 5-6, 12-13, 15, 34-5, 46-51, 57, 67-70, 74, 103, 153-76, 200-1, 215-16; and James Brooke, 70, 72, 88, 98-105, $107,155,157-8,207$

New Guinea, 11, 88, 146, 213

New Zealand, 112, 120

Newbold, T. J., 62

Nicobar Islands, 196

Nicol, J. D., 132

Nieuwland, Maj.-Gen. Penning, 191

North Borneo, State of, 157, 211

North Borneo Company, British, 180, 205-14, 217

\section{O}

Ondaatje, A. M. E., 152

Opium, 8, 24, 73, 98, 128, 166-7, 178, 183, 198 
Oranje-Nassau (coal-mine), 164

Ord, Sir Harry (1819-85), 197

Oriental Coal Co, 177

Outer Possessions, 12, 15, 35, 67-8, 152, $156,161-3,216$

Overbeck, Baron von, 199-201, 207-8, 217

Oya, 191

\section{$\mathbf{P}$}

Padeh, 83

Pagatan, 44

Pahud, C. F. (1803-73), 162-3

Paku, 83

Palawan Island, 10, 195

Palembang, 55, 170

Palmerston, Henry Temple, Viscount $(1784-1865), 119,121,122,124,125$, $141,149,181,184,188$

Pandasan, 114, 197

Parliament, British, 32, 111, 119, 120 , $138,140,144-7$

Parvé, H. A., 49

Pasir, 44, 54, 153-4

Patusen, 85

Pauncefote, Sir Julian (1828-1902), 204, 208

Peel, Sir Robert (1788-1850), 78, 87, 111, 119

Pelarang (coal-mine), 164

Pemangkat, 166, 168

Penang, 13, 16, 28, 40, 41, 51, 52, 54, 55

Pengaron, 164, 176

Pĕngeran Anom of Sambas, 25, 26, 31

Pepper, 4, 5, 7, 12-13, 14, 17, 18, 21, 35, $40,42,110$

Perak, 52

'Period of Neglect', 69

Philippines, Spanish Government of the, $2,4,7,8,10,88,145,196-8,201-2,210$, 217

Phlegethon, H.E.I.C.S., 85-6, 92-3, 114 15,132

Pigafetta, Anthony, 4

Piracy, 30; in Borneo, 1, 23-4, 49-51, 70, $73,94,96,102,105,112,113,117,123-4$, 157, 197; suppression of; by James Brooke, 77, 80-6, 89-90, 92, 94, 112-13, $114,126,129,139-50$; by Raffles, 16, 24-8; by the Royal Navy, 80-6, 90-4, $103,105,114,129,139-50,177-9$

'Pitt Passage", 11

Poeloe Laoet, 44

Pontianak, 6, 26, 32, 33, 67, 68, 159, 168,
183; Sultanate of, 6, 22-8, 49-53, 54, $55,58,153$; Sultans of, $6,23,25-6,37$, 49-51

Pontianak River, 53

Pope-Hennessy, Sir John (1834-91), 191-3

Ports of Borneo, 26-7, 34, 125

Portuguese, 2, 4, 7

Prabu Anom, 175

Prehn Wiese, R. C. van, 167

Premier (merchantman), 154

Principessa Clotilde (warship), 196

Prins, A. (1816-67), 171-4

Prinsep, C. R., 149-50

Private enterprise, 71-2, 78, 129-38, 143, 146-50, 161-5, 176, 199, 216-17

Protectorates, British, 27-8, 184, 187-8, 192, 204-5, 214, 217; German, 213

'Provisional Association', 205

Prussia, 60, 109

Pryer, W. B., 202

\section{$\mathbf{R}$}

Racchia, Capt., 196

Raffles, Sir Thomas Stamford (17811826), 10, 13-16, 22-3, 47, 53-5, 64; as Lieut.-Governor of Java, 15, 19, 28-9, $34,35,49$; and policy in Borneo, 14-16, 19-34, 53, 54, 102; and Singapore, 56, $59-61$

Rajang, River, 139-40, 182, 185, 191

Ranee (tender), 139

Read, W. H. M., 205

Rembang, 39, 41

Residents : British, 16-21, 27-8, 31, 32, 38, 43, 214; Dutch, 49-51, 67-8, 156, 159, 175

Revenues, 28, 32, 50, 51, 129, 200

Riam Kiwa, 164

Rice, 19, 35, 40, 73, 115, 128

Ricketts, Consul, 188-9

Rijk, J. C. (1787-1854), 161

Rijn, Z.M.S., 167-8

Rimbas, 83

Ringdove, H.M.S., 114

Riouw Archipelago, 28, 52, 53, 64, 65, 66, 152

Roberts, Edmund, 109

Rochussen, Jan Jacob (1797-1871), 155-9, $161-5,167-71,174,176$

Ross, Capt., 179, 198-9

Royalist (yacht), 70, 71, 74, 76, 84, 98, 99

Royalist, H.M.S., 114, 139 
Russell, Lord John, later Earl (17921878), 119, 121

Russia, 56, 60

\section{S}

'Sabah', 200

Sabine (corvette), 109

Sadong, River, 69, 75

St. John, Horace, 142-3

St. John, Sir Spenser (1825-1910), 182

Salisbury, Robert Gascoyne-Cecil, Marquis of (1830-1903), 210, 213

Salt, 19, 47, 70, 73, 166-7

Saman, Haji, 112, 115

Samarahan, River, 75, 182

Samarang, 15, 49

Samarang, H.M.S., 79, 80, 84-6, 92-3, 145, 154-5

Samarinda, 102, 164

Sambalioeng, 153-5

Sambas, 2, 3, 5, 24, 26, 31, 33, 159, 16674 ; Bèndahara of, 31; Sultanate of, 22 , 23-8, 31, 49-51, 54, 58, 67-70, 73-4, 99101, 153, 157, 166-74, 183 ; Sultans of, $22,25-7,31,49,51,74,166,167,170$, 174; Těměnggong of, 173

Sambas River, 26, 27, 51

Sampit, 44

San T'iao Kou (kongsi), 166, 168, 170

San Tien Hui (secret society), 169

Sandakan, 157, 198, 200-2

Sandwich Islands, 56

Sanggau, 101, 157

Sarawak, 2, 23, 72-3, 120-1, 128-38; the Brooke regime in, $72-7,101,124,126$, $127,128-30,133,146,150-1,161,176$, 215, 217; Chinese in, 73, 100, 166, 170, 183 ; civil war in, 74-5, 77, 99; expansion of, 84, 92-3, 147-50,182, 191, 194 ; proposed as a British colony, 87-9, $120-1,184-5,187,189$; recognition of independent status of, 86-9, 94, 121-2, 147-50, 181-90, 208, 214; relations with Brunei, 181-90, 191-5; with the Dutch Government, 69-70, 99-101, 137; suppression of piracy in, 80-6, 139-50

Sarawak, Government of, 186, 189, 191-4, 207-14

Sarawak, River, 70, 84

Saribas pirates, 81-4, 92, 139-43, 149

Schomburgk \& Co, 198-9

Scott, J., 137

Sebatik Island, 203
Seboekoe River, 200-3, 206

Secret Committee, 33, 53, 54, 58

Sedauw, River, 167-8

Sěkrang pirates, 81-6, 92, 139-43, 149

Sěkrang River, 85

Selangor, 52

Sematan, 69

Seminis, 22, 166

Sepang, 166

Seychelles Islands, 95

Siak, 52, 53

Siam, 28, 109

Singapore, 11, 64, 71, 85, 87, 90, 95, 98, $114,115,117,119,121,178$; AngloDutch controversy over, $56,61,62$, $65-6,106$; foundation of, $10,54,56$; its trade with Borneo, 69-70, 73-6, 83, $105,129,131,138,166-7,191,197-8$

Singapore, Straits of, 63-7, 106-7

Singapore Chamber of Commerce, 72

Singapore Free Press, 127, 140

Singh Raja (war-prahu), 139

Sintang, 44, 101, 156, 158

Slavery, 94, 112, 138, 211

Smuggling, 69-70, 73, 101, 105, 155, 166, 183, 198

Soekadana, 3, 5, 6, 24

Soembawa, 62

Soerabaja, 3

Sorg, Lt.-Col., 168

South Coast of Borneo, 1, 4-7, 12-13, 17, $21,42-9,67-70,111,151,159,161-5$, $174-6,200$

'Sow' Dyaks, 83

Spain, 2, 4, 7, 10, 88, 145, 178, 196-8, 210,217

Speculators, commercial, 129-38, 143, 161-5, 199

Spiteful, H.M.S., 114

Sri Vijaya, 2

Stanley, Lord, see Derby, 14th Earl of

States-General, 160, 203, 207

Steamships, 11, 29, 80, 163

Stephen, Sir James (1789-1859), 119-21

Straits Settlements, 85, 178, 197, 214

Straits Times, 140

Strategy, 10-11, 15, 32, 54-7, 87, 95, 96, $111,115,213,217$

Stuart, Robert, 39

Sugut, River, 157

Sultana (merchantman), 81, 90

Sulu, Sultans of, 9-10, 153, 196-8, 201

Sulu Archipelago, 9-10, 28, 88, 109, 196-8, 202 
Sulu Sea, 11, 111

Sulus, 3, 10, 197-8

Sumatra, 2, 3, 28, 54, 62-4, 106, 109, 155

Sunda, Straits of, 11, 55

\section{$\mathrm{T}$}

Ta Kang (kongsi), 166-74

Tabanio, Fort, 5, 17, 19, 44, 47

Taboer, Goenong, 153-5

Tajan, 50, 68

Tamjid Illah, 175-6

Tanah Boemboe, 153

Tanah Laoet, 161-2

Tarakan Island, 206

Tatas, Fort, 7, 12, 17, 42, 43, 44

Tawau, 206

Tawi Tawi Island, 197

Taxation, 17, 24, 153, 166, 168, 171, 200

Tempasuk, 92, 114

Templer, John C., 79, 105, 128, 129, 135

Tenggarong, 102

Ternate, 146

Thian $\mathrm{Ti}$ Hui (secret society), 183

Thiel, Lt.-Col. S. J. van, 12

Thorbecke, Johan R. (1798-1872), 159

Tidoeng, 153

Tin, 23, 62, 162

Tinagat, Batu, 202-3, 206

Tongking, 213

Torrey, Joseph W., 195-6, 199, 217

Trade, 16, 24, 26-8, 51, 73, 75; American (with Borneo) 109-10, (with China) 56; British (with Borneo) 7-10, 26-8, $35,70,86,94,102,104,124-5,129,148-$ $50,177,179,210$, (with China) 8-11, $51,57,65,80,87,95,98,115,120,180$, 213, (with East Indies) 8-11, 26-7, 30-2, 51-9, 81, 115-16, 215; Dutch (with Borneo) 4-7, (in East Indies) 56-7

Treacher, W. H., 206-7, 209, 212-13

Treasury, British, 49, 94, 117

Treaties, 55, 66, 69-70, 154-5; between Great Britain and Brunei (1844) 84, 122 , (1847) 124-5, 130,133,160, 192, 194, 207-8; between Great Britain and Holland (1814) 33, 35, 36-9, 43, 48, 51, 53, $60,61,(1824) 62-7,70,100,105-8,158$, 204, 206; between English East India $\mathrm{Co}_{0}$ and Bandjermasin (1812), 16-17, $33-4,37-9$, Sambas (1813) 27-8, 33, Sulu (1761-4) 9-10; between the $\mathrm{Ne}-$ therlands Indian Government and Bornean princes, 5-7, 44-5, 49, 50, 51, 58-9, $152-4,157,174$; between the U.S. and
Sarawak, 181-2; between Spain and Sulu (1851) 196, (1878) 198, 202

Tribute money, 126, 182, 191, 193, 200-1, 209

Trincomalee, 32, 95

Twist, A. J. Duymaer van (1809-87), 170-1

$\mathrm{U}$

Undup, River, 85

United States of America, 55-6, 109-10, 119, 181-2, 195

'Usman, Sharif, 90-1, 94

Usop, Pĕngeran, 74, 77, 86, 90-1, 94

Ussher, Governor, 193

\section{$\mathrm{V}$}

Victoria Harbour, 179

Vienna, 58, 199

Vi.ten (steamer), 84

W

Wahl, Asst.-Resident van de, 16, 41, 47

Waitangi, Treaty of (1840), 120

Watson, Lt.-Col. J., 26

Weddik, A. L., 152, 154, 156, 158

Weld, Sir Frederick (1823-91), 214

West Coast of Borneo, 1-6, 22-8, 31, 33, $49-53,54,59,67-70,81,157-9,166-74$, 176,200

West Indies, 112, 145

Westerafdeeling, 159, 166-74

'Western Passage', 11

Wilkes, Adm. Charles, 110

Willem I of the Netherlands, King (17721843), 33, 35, 48

Willem II of the Netherlands, King (1792-1849), 101, 159

Willer, T. J., 167-74

Wise, Henry, 78-80, 86-9, 96, 104, 111, $113,126-9,133-8,143,146,217$

Wolf, H.M.S., 134,

Wynn, Charles W. W. (1775-1850), 60, $61,64,106$

$\mathrm{Y}$

Young Queen (brig), 102

Z

Zamboanga, 196

Zuid- en Oosterafdeeling, 159, 163-5, 174-6 
Graham Irwin - 978-90-04-28637-5 Downloaded from Brill.come4/26/2023 02:45:21AM via free access 


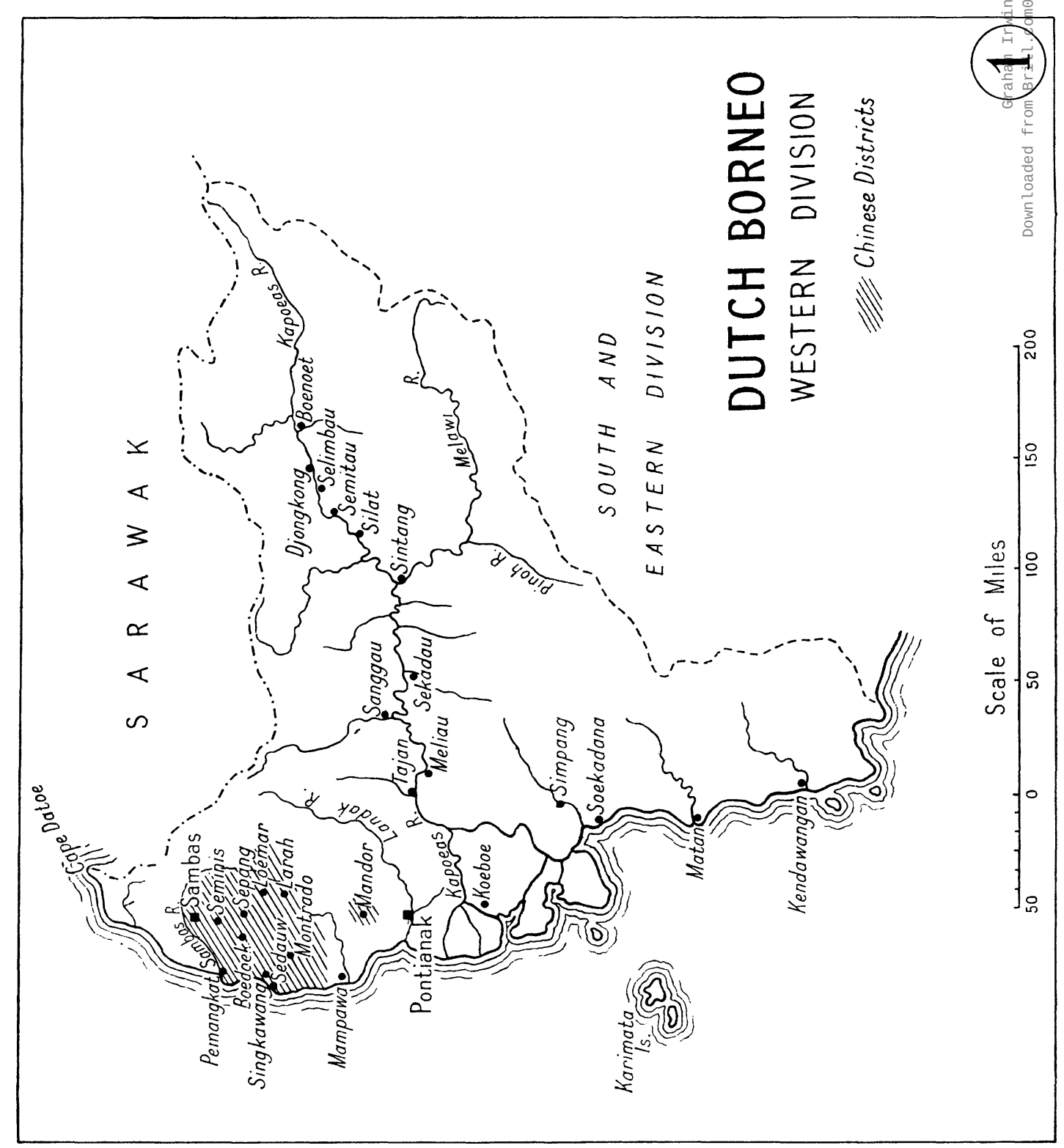


Graham Irwin - 978-90-04-28637-5 Downloaded from Brill.come4/26/2023 02:45:21AM via free access 


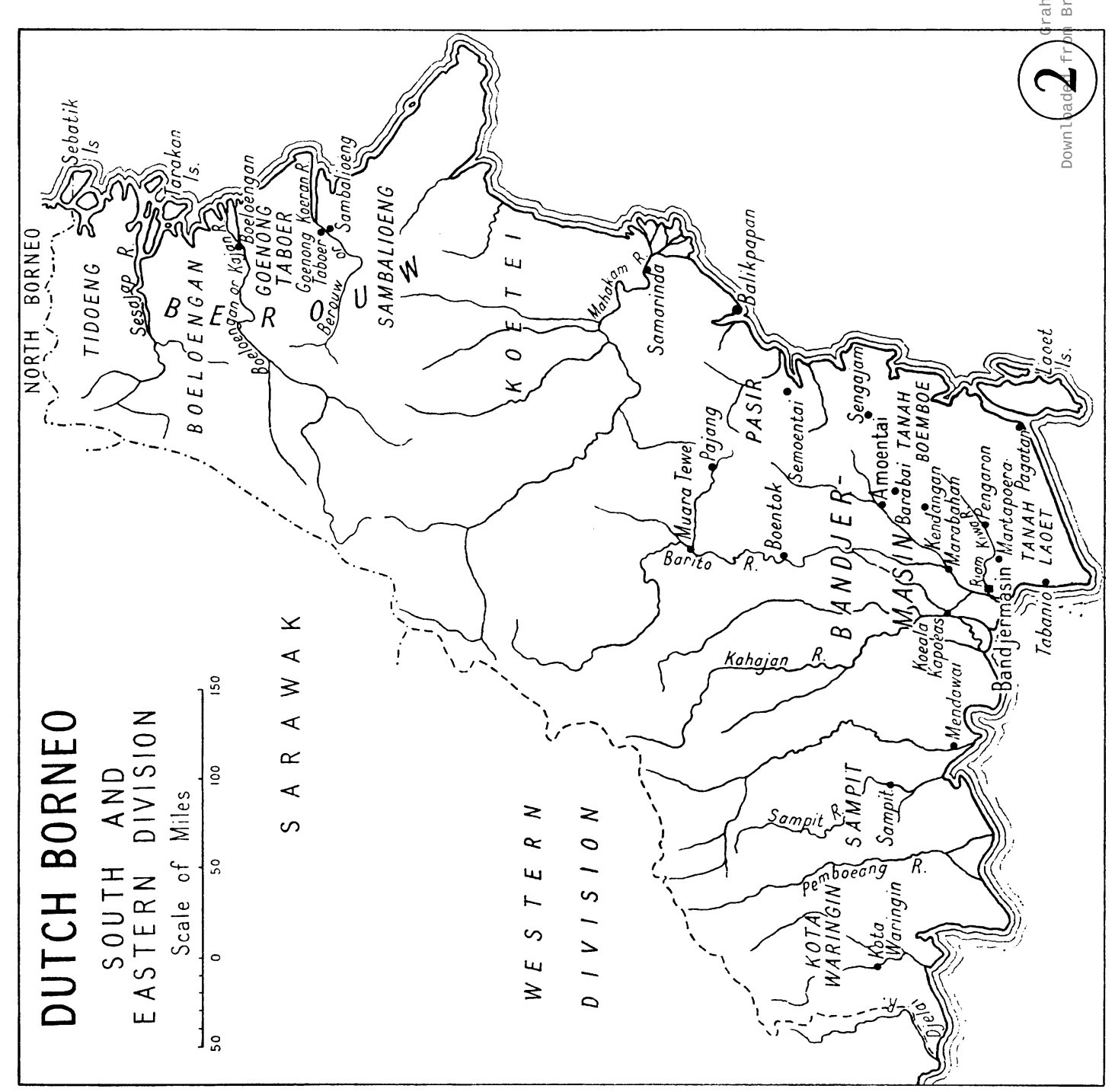


Graham Irwin - 978-90-04-28637-5 Downloaded from Brill.come4/26/2023 02:45:21AM via free access 


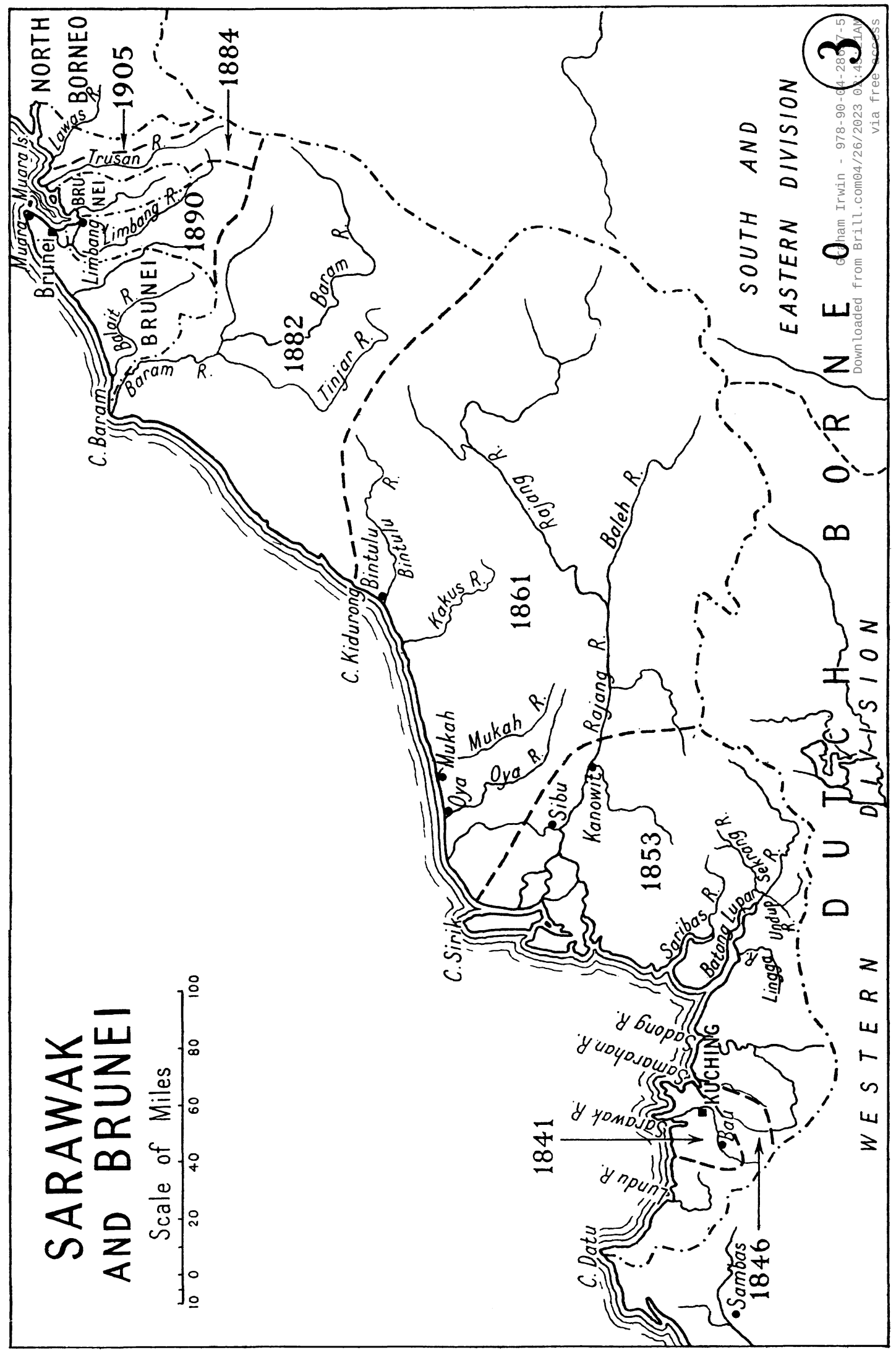


Graham Irwin - 978-90-04-28637-5

Downloaded from Brill.com $\odot 4 / 26 / 2023$ 02:45:21AM 


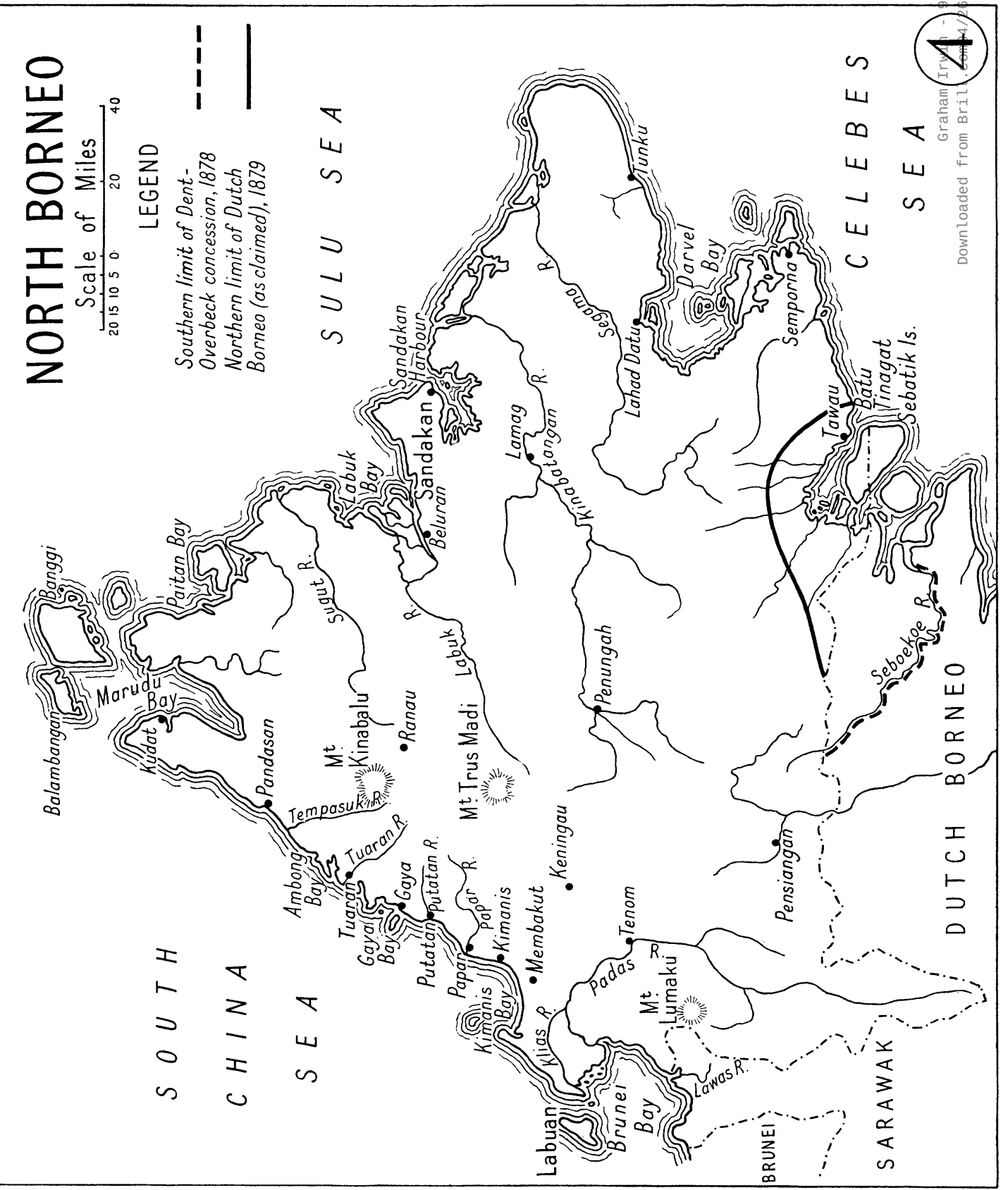

